Prepared in cooperation with the U.S. Army Corps of Engineers

Channel Change and Bed-Material Transport in the Umpqua River Basin, Oregon

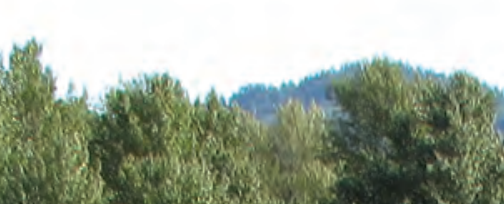

\title{
,
}


Cover: Photograph of South Umpqua River at floodplain kilometer 219.9 (river mile 150.5) near Myrtle Creek, looking upstream, August 25, 2009. (Photograph taken by Jim O'Connor, U.S. Geological Survey.) 


\section{Channel Change and Bed-Material Transport in the Umpqua River Basin, Oregon}

By J. Rose Wallick, Jim E. O'Connor, Scott Anderson, Mackenzie Keith, Charles Cannon, and John C. Risley

Prepared in cooperation with the U.S. Army Corps of Engineers

Scientific Investigations Report 2011-5041 


\title{
U.S. Department of the Interior \\ KEN SALAZAR, Secretary \\ U.S. Geological Survey \\ Marcia K. McNutt, Director
}

\author{
U.S. Geological Survey, Reston, Virginia: 2011
}

For more information on the USGS - the Federal source for science about the Earth, its natural and living resources, natural hazards, and the environment, visit http://www.usgs.gov or call 1-888-ASK-USGS.

For an overview of USGS information products, including maps, imagery, and publications, visit http://www.usgs.gov/pubprod

To order this and other USGS information products, visit http://store.usgs.gov

Any use of trade, product, or firm names is for descriptive purposes only and does not imply endorsement by the U.S. Government.

Although this report is in the public domain, permission must be secured from the individual copyright owners to reproduce any copyrighted materials contained within this report.

Suggested citation:

Wallick, J.R., O'Connor, J.E., Anderson, S., Keith, M., Cannon, C., and Risley, J.C., 2011, Channel change and bedmaterial transport in the Umpqua River basin, Oregon: U.S. Geological Survey Scientific Investigations Report 2011-5041, $112 \mathrm{p}$. 


\section{Contents}

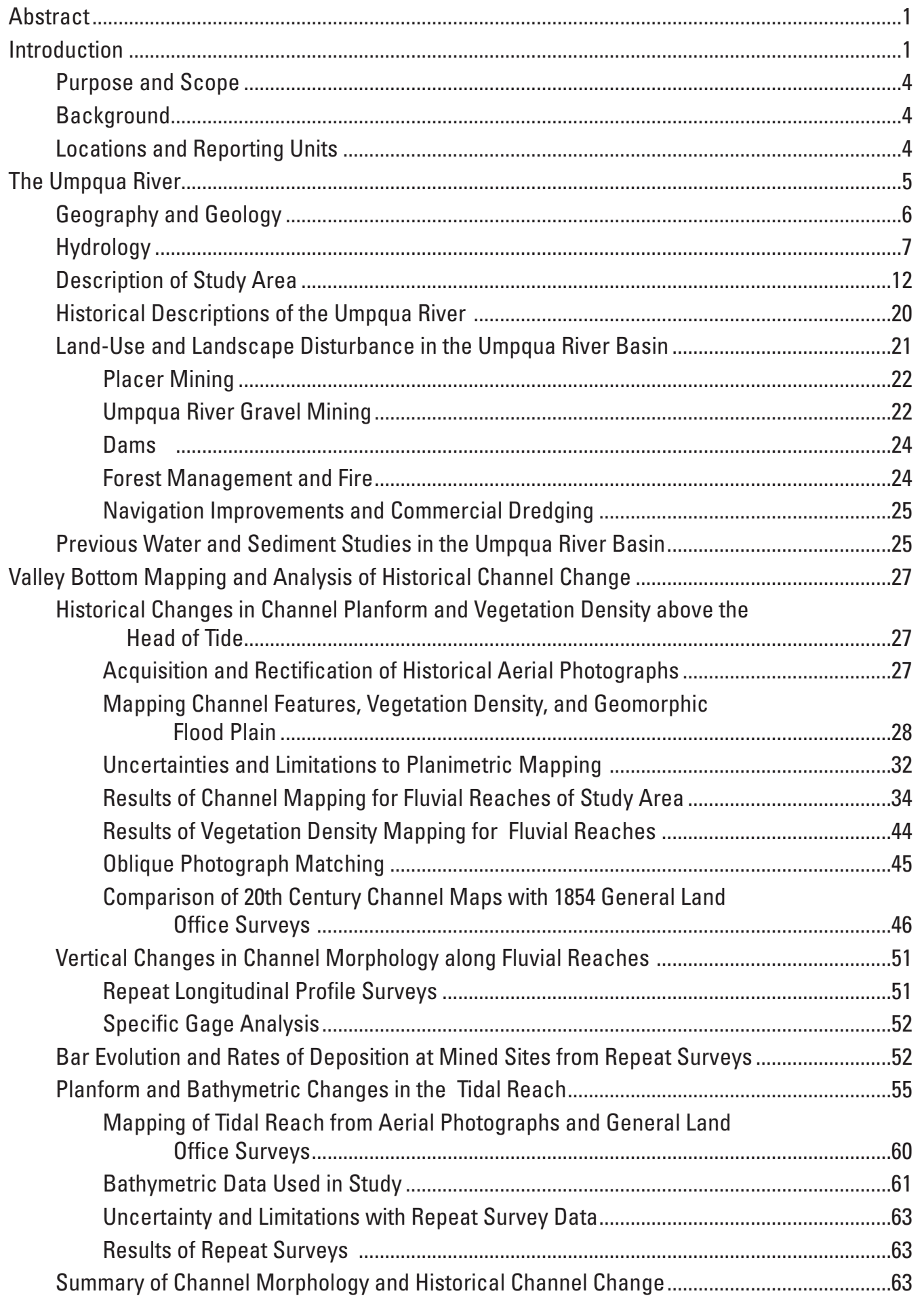




\section{Contents-Continued}

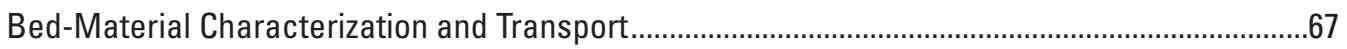

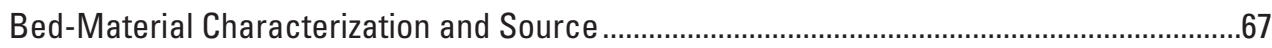

Gravel Distribution and Textures................................................................................67

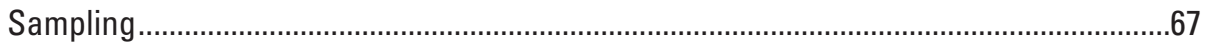

Assessment of Bed-Material Sizes ...............................................................................72

Bed-Material Lithology and Sources .......................................................................

Estimation of Bed-Material Transport Capacity from Transport Equations .............................75

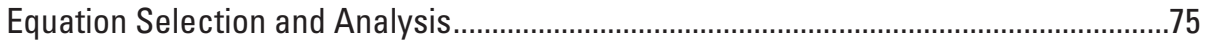

Uncertainty and Limitations ........................................................................................77

Results of Bed-Material Transport Equations..............................................................

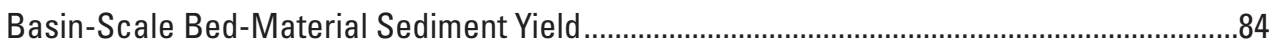

Sediment Yield Measurements....................................................................................84

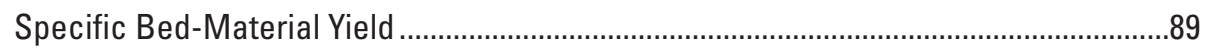

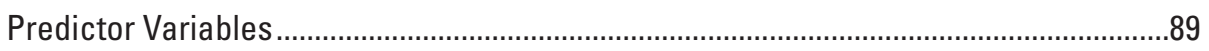

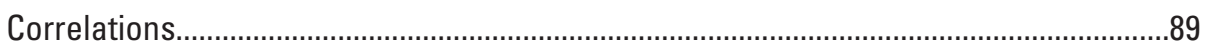

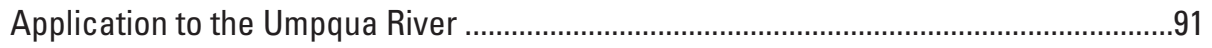

Summary of Bed-Material Characterization and Transport ...................................................94

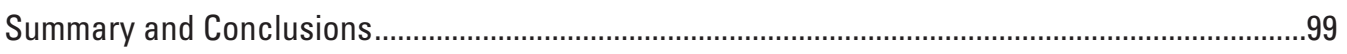

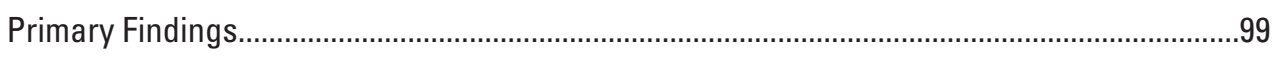

Implications Regarding Future Trends and Monitoring Strategies ......................................102

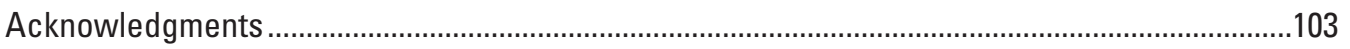

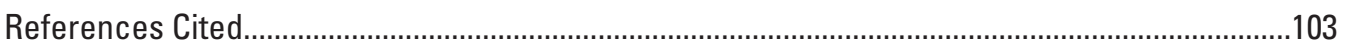

Appendix A. Location Information for Historical and Repeat Oblique Photography

Completed for the Umpqua River, Oregon, Study Area.

Appendix B. General Land Office Survey Notes and Approximate Location for Meandered Portions of the Umpqua River, Oregon, Between 1853 and 1894

Appendix C. Particle-Size Distributions at Sediment Sampling Sites in the Umpqua River Basin, Oregon, by Reach. 


\section{Figures}

Figure 1. Map showing the Umpqua River, Oregon, drainage basin and study area $\ldots \ldots \ldots .2$

Figure 2. Photographs of gravel bars and bedrock outcrops in the Umpqua River, Oregon... 3

Figure 3. Diagram showing the longitudinal profile and cumulative drainage area of the Umpqua River basin, Oregon

Figure 4. Graphs showing mean daily discharge for selected U.S. Geological Survey streamflow-gaging stations in the Umpqua River basin, Oregon

Figure 5. Graphs showing annual peak discharge for selected U.S. Geological Survey streamflow-gaging stations in the Umpqua River basin, Oregon $\ldots \ldots \ldots \ldots \ldots \ldots 10$

Figure 6. Map showing channel planform in the Tidal reach of the Umpqua River, Oregon ... 14

Figure 7. Map showing channel planform in the Coast Range reach of the Umpqua

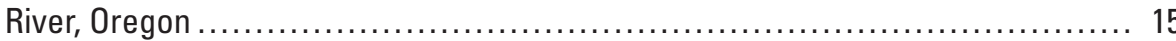

Figure 8. Map showing channel planform of the Garden Valley reach of Umpqua River,

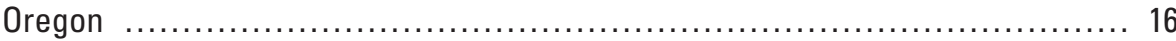

Figure 9. Map showing channel planform of the Roseburg reach of the South Umpqua River, Oregon

Figure 10. Map showing channel planform of the Days Creek reach of Umpqua River, Oregon 18

Figure 11. Map showing channel planform of the North Umpqua reach of the North Umpqua River, Oregon

Figure 12. Photograph, circa 1890s, of the South Umpqua River upstream of Mount Nebo near Roseburg, Oregon

Figure 13. Photographs of hydraulic mining in the Olalla District, Lookingglass Creek drainage, Oregon

Figure 14. Graph showing annual sediment volume removed between 1949 and 2002 by commercial and navigational dredging in the Umpqua River estuary, Oregon ...... 26

Figure 15. Aerial photographs showing examples of mapping units used when creating historical channel maps of the Umpqua River basin, Oregon

Figure 16. Photographs showing examples of gravel bars in close proximity to bedrock outcrops in the Umpqua River, Oregon

Figure 17. Graph showing relation of bar area to discharge in photographs of the Days Creek, Roseburg, and Garden Valley reaches of the Umpqua River, Oregon, 1995-2009

Figure 18. Graphs showing a sSummary of historical channel change 1939-2009 for fluvial reaches in the Umpqua River Basin, Oregon.

Figure 19. Graphs showing(A) The fraction of water, bedrock, and gravel bars in each flood-plain kilometer transect in the Umpqua and South Umpqua Rivers, Oregon, as mapped from 2005 aerial photographs. Downstream of FPKM 25 in the Tidal reach, channel area increases substantially in the lower Umpqua River estuary. (B) Flood-plain width by flood-plain kilometer

Figure 20. Graph showing the size and location of mapped gravel bars along the South Umpqua and Umpqua Rivers, Oregon

Figure 21. Graphs showing reach-segregated changes in bar area in the Umpqua River basin, Oregon, 1939-2005

Figure 22. Photographs showing examples of channel change at selected sites on the Umpqua and South Umpqua Rivers, Oregon, 1939-2005 ..................... 41

Figure 23. Photographs showing changes in bar morphology between 1995 and 2000 for select sites on the Umpqua and South Umpqua Rivers, Oregon 


\section{Figures-Continued}

Figure 24. Graphs showing historical changes in vegetation density within the active channel for fluvial reaches of the Umpqua River basin, Oregon, 1939-2009

Figure 25. Graphs showing patterns of vegetation colonization on bare gravel bars in the Umpqua River basin, Oregon, 1939-2005, by reach ....

Figure 26. Photographs showing historical channel changes in the Umpqua River basin, Oregon, 1920s-2009

Figure 27. Photographs showing historical changes in riparian vegetation in the Umpqua River basin, Oregon, 1920s-2009.

Figure 28. Maps showing comparison of channel position at selected sites along the North Umpqua reach as depicted in General Land Office surveys from 1853 to 1855 and channel maps based on aerial photographs from 1939

Figure 29. Diagram showing repeat longitudinal profiles of the main stem Umpqua River between Elkton and the confluence of the North and South Umpqua Rivers, Oregon, 1914-2009...

Figure 30. Graphs showing stage-discharge rating-curve elevations for specific discharges for long-term main stem streamflow gages in the Umpqua River basin, Oregon

Figure 31. Graphs showing gravel bar volume changes during 2001-09 at instream gravel mining sites along the South Umpqua River, Oregon

Figure 32. Graphs showing channel planform changes during 1939-2005 between FPKM 7 and 40 for the Tidal reach of the Umpqua River, Oregon

Figure 33. Maps showing comparison of channel planform for the Tidal reach of the Umpqua River, Oregon, as depicted in 1857-74 General Land Office surveys, with aerial photographs from 1939

Figure 34. Maps showing bathymetric changes to the Tidal reach of the Umpqua River, Oregon, as detected in historical navigation surveys from 1886, 1920, and

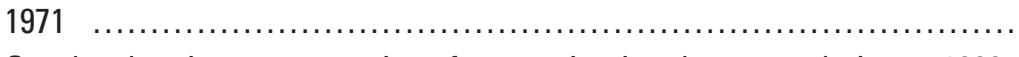

Figure 35. Graphs showing cross sections from navigational surveys dating to 1886 ,

Figure 36 . Photographs showing examples of bed-material sampling sites in the

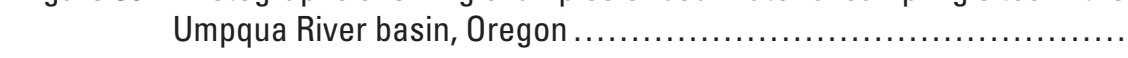

Figure 37. Graphs showing bed-material grain size, armoring ratios, and lithology for

Figure 38. Graphs showing computed bedload transport rating curves for selected sites in the Umpqua River basin, Oregon, as computed from the Parker $(1990 a, b)$ equation.

Figure 39. Graph showing effect of grain size, slope, water depth, and flow on annual bedload transport capacity

Figure 40. Graphs showing longitudinal variation in calculated transport capacity for bed-material sampling sites on the Umpqua and South Umpqua Rivers, Oregon

Figure 41. Graphs showing annual computed transport capacity for water years 1951-2008 for selected sites in the Umpqua and South Umpqua Rivers, Oregon.

Figure 42. Graph showing relation of reference discharge to mean annual transport capacity in the Umpqua and South Umpqua Rivers, Oregon, as computed using the Parker equation 


\section{Figures-Continued}

Figure 43. Graphs showing regional sediment yield regressions, as calculated for 26 basins in Oregon and northern California

Figure 44. Graph showing predicted bed-material yield for South Umpqua and Umpqua

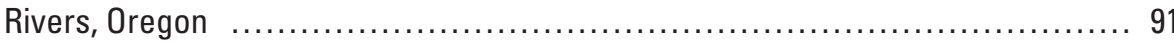

Figure 45. Photograph showing examples of disintegrating sandstone clasts derived from the Tyee Formation in the Oregon Coast Range

Figure 46. Comparison between longitudinal distribution of clast lithologies in bed-material sampling sites, fraction of contributing area underlain by these lithologies, and expected lithologies based on sediment yield analysis .......... 93

Figure 47. Graph showing predicted bed-material yield in the Umpqua River basin, Oregon, under different scenarios of attrition and tributary contribution

\section{Tables}

Table 1. U.S. Geological Survey streamflow-gaging stations used in this study

Table 2. U.S. Geological Survey streamflow-gaging stations in the Umpqua River, Oregon, used in peak flow analysis

Table 3. Geomorphic and channel characteristics for reaches in the Umpqua River basin, Oregon.

Table 4. Channel trends and anthropogenic impacts for reaches in the Umpqua River basin, Oregon

Table 5. Aerial photographs and orthophotographs used in the sediment transport study, Umpqua River basin, Oregon

Table 6. Stream discharge for the aerial photography used in the sediment transport study of the Umpqua River basin, Oregon

Table 7. Map and survey data reviewed in the Umpqua River, Oregon, sediment-transport study

Table 8. Survey data for mined sites on the South Umpqua River, Oregon, 2001-2009 ..... 56

Table 9. Bed-material data and transport rates in the Umpqua River basin, Oregon ........ 68

Table 10. Sources of sediment yield data for Oregon and California watersheds ........... 85

Table 11. Estimated bed-material flux values for the Umpqua and South Umpqua Rivers, Oregon, as calculated from surveys at mined sites, transport capacity equations, sediment yield analysis, and suspended sediment measurements

Table 12. Reach-segregated bed-material flux values for the Umpqua and South Umpqua Rivers, as calculated from surveys at mined sites, transport capacity equations, sediment yield analysis, and suspended-sediment measurements 


\section{Conversion Factors, Datums, and Abbreviations and Acronyms}

Conversion Factors

\begin{tabular}{|c|c|c|}
\hline Multiply & By & To obtain \\
\hline \multicolumn{3}{|c|}{ Length } \\
\hline centimeter $(\mathrm{cm})$ & 0.3937 & inch (in.) \\
\hline millimeter (mm) & 0.03937 & inch (in.) \\
\hline meter (m) & 3.281 & foot $(\mathrm{ft})$ \\
\hline kilometer (km) & 0.6214 & mile (mi) \\
\hline meter $(\mathrm{m})$ & 1.094 & yard (yd) \\
\hline \multicolumn{3}{|c|}{ Area } \\
\hline square meter $\left(\mathrm{m}^{2}\right)$ & 10.76 & square foot $\left(\mathrm{ft}^{2}\right)$ \\
\hline square kilometer $\left(\mathrm{km}^{2}\right)$ & 0.3861 & square mile $\left(\mathrm{mi}^{2}\right)$ \\
\hline \multicolumn{3}{|c|}{ Volume } \\
\hline liter (L) & 61.02 & cubic inch (in $\left.{ }^{3}\right)$ \\
\hline cubic meter $\left(\mathrm{m}^{3}\right)$ & 35.31 & cubic foot $\left(\mathrm{ft}^{3}\right)$ \\
\hline cubic meter $\left(\mathrm{m}^{3}\right)$ & 1.308 & cubic yard $\left(\mathrm{yd}^{3}\right)$ \\
\hline \multicolumn{3}{|c|}{ Flow rate } \\
\hline cubic meter per second $\left(\mathrm{m}^{3} / \mathrm{s}\right)$ & 70.07 & acre-foot per day (acre-ft/d) \\
\hline meter per second (m/s) & 3.281 & foot per second (ft/s) \\
\hline cubic meter per second $\left(\mathrm{m}^{3} / \mathrm{s}\right)$ & 35.31 & cubic foot per second $\left(\mathrm{ft}^{3} / \mathrm{s}\right)$ \\
\hline cubic meter per second $\left(\mathrm{m}^{3} / \mathrm{s}\right)$ & 22.83 & million gallons per day (Mgal/d) \\
\hline \multicolumn{3}{|c|}{ Mass } \\
\hline gram (g) & 0.03527 & ounce, avoirdupois (oz) \\
\hline kilogram (kg) & 2.205 & pound avoirdupois (lb) \\
\hline metric ton & 1.102 & ton, short $(2,000 \mathrm{lb})$ \\
\hline metric ton & 0.9842 & ton, long $(2,240 \mathrm{lb})$ \\
\hline
\end{tabular}

Datums

Vertical coordinate information is referenced to the North American Vertical Datum of 1988 (NAVD 88).

Horizontal coordinate information is referenced to the North American Datum of 1983 (NAD 83).

Abbreviations and Acronyms

$\begin{array}{ll}\text { BAGS } & \text { Bedload Assessment in Gravel-bedded Streams } \\ \text { FERC } & \text { Federal Energy Regulatory Commission } \\ \text { FPKM } & \text { flood-plain kilometer } \\ \text { GLO } & \text { General Land Office } \\ \text { MLLW } & \text { mean lower low water } \\ \text { NAIP } & \text { National Agriculture Inventory Program } \\ \text { NOAA } & \text { National Oceanic and Atmospheric Administration } \\ \text { NUFPKM } & \text { North Umpqua River flood-plain kilometer } \\ \text { NURKM } & \text { North Umpqua river kilometer } \\ \text { RKM } & \text { river kilometer } \\ \text { RM } & \text { river mile } \\ \text { RMSE } & \text { root mean square error } \\ \text { TIN } & \text { Triangulated Irregular Network } \\ \text { URN } & \text { Umpqua River Navigation Company } \\ \text { USACE } & \text { U.S. Army Corps of Engineers } \\ \text { USGS } & \text { U.S. Geological Survey }\end{array}$




\title{
Channel Change and Bed-Material Transport in the Umpqua River Basin, Oregon
}

\author{
By J. Rose Wallick, Jim E. O'Connor, Scott Anderson, Mackenzie Keith, Charles Cannon, and John C. Risley
}

\section{Abstract}

The Umpqua River drains 12,103 square kilometers of western Oregon; with headwaters in the Cascade Range, the river flows through portions of the Klamath Mountains and Oregon Coast Range before entering the Pacific Ocean. Above the head of tide, the Umpqua River, along with its major tributaries, the North and South Umpqua Rivers, flows on a mixed bedrock and alluvium bed, alternating between bedrock rapids and intermittent, shallow gravel bars composed of gravel to cobble-sized clasts. These bars have been a source of commercial aggregate since the mid-twentieth century. Below the head of tide, the Umpqua River contains large bars composed of mud and sand.

Motivated by ongoing permitting and aquatic habitat concerns related to in-stream gravel mining on the fluvial reaches, this study evaluated spatial and temporal trends in channel change and bed-material transport for 350 kilometers of river channel along the Umpqua, North Umpqua, and South Umpqua Rivers. The assessment produced (1) detailed mapping of the active channel, using aerial photographs and repeat surveys, and (2) a quantitative estimation of bed-material flux that drew upon detailed measurements of particle size and lithology, equations of transport capacity, and a sediment yield analysis.

Bed-material transport capacity estimates at 45 sites throughout the South Umpqua and main stem Umpqua Rivers for the period 1951-2008 result in wide-ranging transport capacity estimates, reflecting the difficulty of applying equations of bed-material transport to a supplylimited river. Median transport capacity values calculated from surface-based equations of bedload transport for each of the study reaches provide indications of maximum possible transport rates and range from 8,000 to 27,000 metric tons per year (tons/yr) for the South Umpqua River and 20,000 to 82,000 metric tons/yr for the main stem Umpqua River upstream of the head of tide; the North Umpqua River probably contributes little bed material. A plausible range of average annual transport rates for the South and main stem Umpqua Rivers, based on bedload transport capacity estimates for bars with reasonable values for reference shear stress, is between 500 and 20,000 metric tons/yr.
An empirical bed-material yield analysis predicts 20,000-50,000 metric tons/yr on the South Umpqua River and main stem Umpqua River through the Oregon Coast Range, decreasing to approximately 30,000 metric tons/yr at the head of tide. Surveys of individual mining sites in the South Umpqua River indicate minimum local bed-material flux rates that are typically less than 10,000 metric tons/yr but range up to 30,600 metric tons/yr in high-flow years.

On the basis of all of these analyses, actual bedload flux in most years is probably less than 25,000 metric tons/yr in the South Umpqua and main stem Umpqua Rivers, with the North Umpqua River probably contributing negligible amounts. For comparison, the estimated annual volume of commercial gravel extraction from the South Umpqua River between 2001 and 2004 ranged from 610 to 36,570 metric tons, indicating that historical in-stream gravel extraction may have been a substantial fraction of the overall bedload flux.

\section{Introduction}

The Umpqua River drains 12,103 km² of western Oregon before entering the Pacific Ocean at Winchester Bay near the town of Reedsport (fig. 1). For much of its length, the Umpqua River and its two main tributaries, the North Umpqua and South Umpqua Rivers, flow on a bed alternating between bedrock and coarse alluvium, locally flanked by gravel bars and sandy flood-plain deposits (fig. 2). The lowermost $40 \mathrm{~km}$ of the Umpqua River is tidally affected, where the low gradient river flows over a sand and gravel bottom flanked by muddy tidal flats and flood-plain deposits.

For the last several decades, some of these gravel bars and in-stream alluvial deposits, particularly along the South Umpqua River and main stem Umpqua River, have been mined for aggregate. Ongoing permitting actions have instigated questions of possible effects from such mining and other land-use activities on physical channel conditions (for example, Kondolf, 1994, 1997), prompting the U.S. Army Corps of Engineers (USACE), in conjunction with regulatory agencies and stakeholder groups, to request from the U.S. Geological Survey (USGS) an assessment of bed-material transport and changes in channel and gravel-bar conditions for the Umpqua River and alluvial reaches of the North and South Umpqua Rivers. This study incorporates and supersedes a 2009 reconnaissance study (O’Connor and others, 2009). 


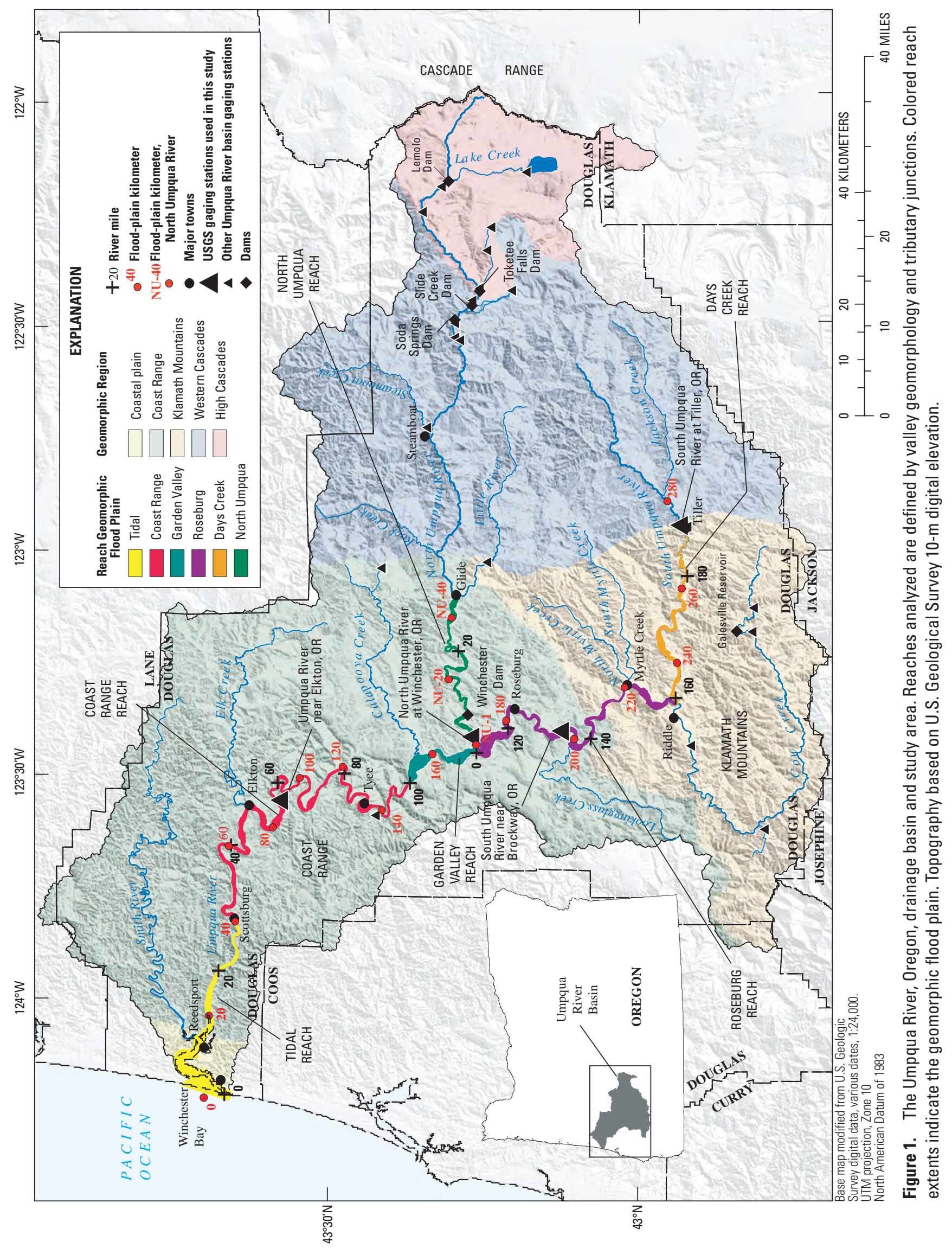




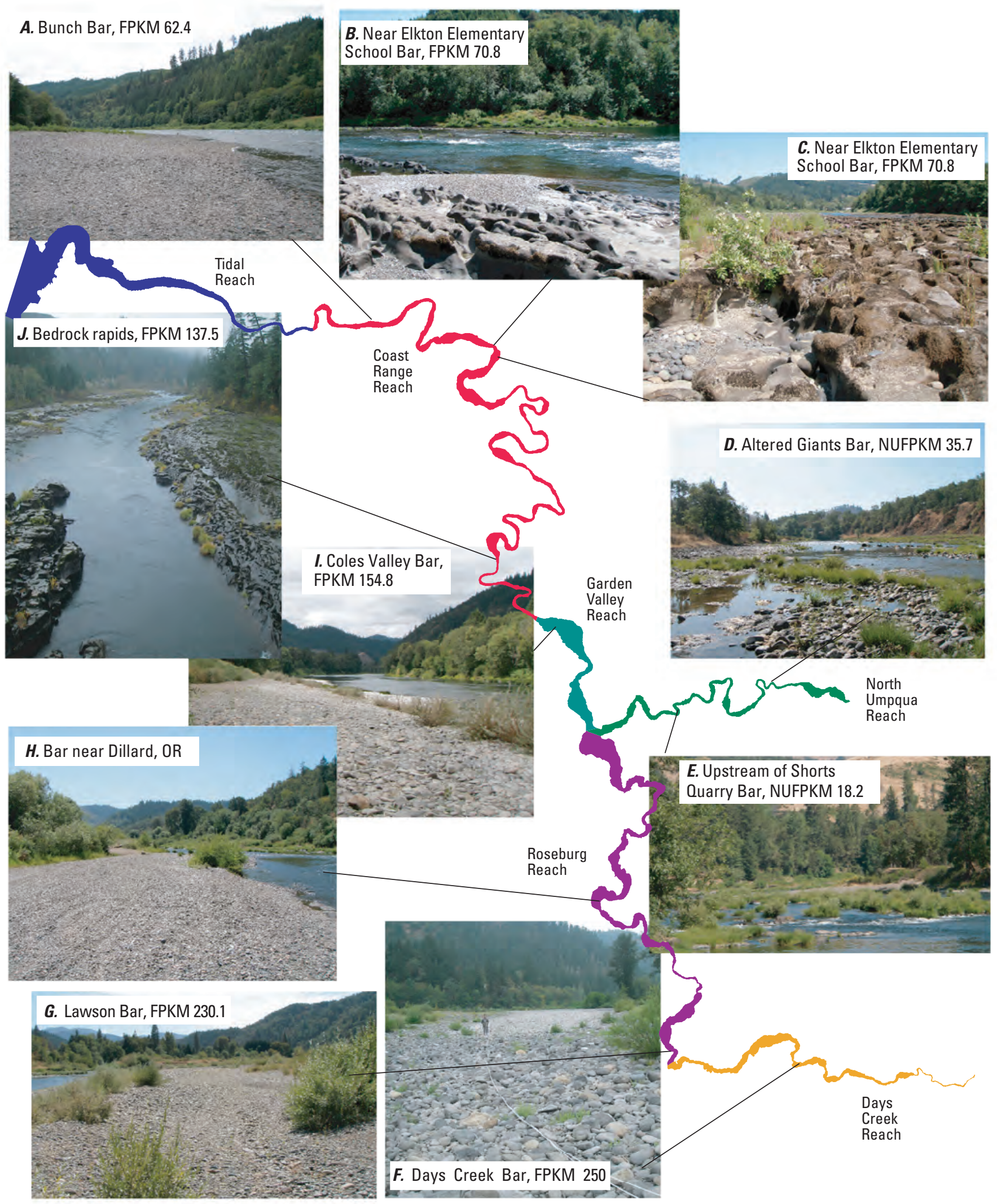

Figure 2. Gravel bars and bedrock outcrops in the Umpqua River, Oregon. Descriptions include flood-plain kilometer (FPKM) and North Umpqua River flood-plain kilometer (NUFPKM). 


\section{Purpose and Scope}

This report summarizes temporal trends of channel and gravel-bar area and provides estimates of sediment flux and sediment yield, with the goal of estimating temporal and spatial trends in bedload transport, deposition, and erosion in the main stem Umpqua River, as well as the semi-alluvial portions of the North Umpqua and South Umpqua Rivers. These analyses were based on mapping of the channel and flood plains from historical and current aerial photographs, sampling of bed-material size distributions, survey records from aggregate mining operations, sediment yield estimates derived from regional analyses, and site-specific sediment transport modeling. The detailed channel maps developed in this study can also be used in future analyses to detect changes in planform and bar morphology that may arise due to changes in sediment balances and transport. The scope of the study follows a process established in the State of Oregon to address permitting issues for in-channel gravel extraction.

\section{Background}

The natural resources of the Umpqua River basin are numerous, ranging from highly productive Douglas-fir forests in the upper basin, to ranches along the low-lying valleys, to coastal fisheries at its mouth. The basin also provides diverse habitats for aquatic and riparian species and supports populations of steelhead, coho salmon, and Chinook salmon, as well as Pacific lamprey and cutthroat trout (Geyer, 2003 $\mathrm{a}-\mathrm{d})$. Issues of fish habitat, water quality, and changing land-use laws, similar to other basins in the Western United States, have motivated new efforts to manage the Umpqua River and its tributaries for multiple resources.

In Oregon, rivers potentially subject to in-channel gravel extraction undergo a two-phase process of review and assessment by an interagency team co-chaired by the USACE and the Oregon Department of State Lands. The first phase is a preliminary assessment of "vertical stability" primarily based on available information. If Phase I analysis shows no clear evidence of adverse channel or flood-plain conditions, a Phase II analysis may be initiated to provide more information relevant to permitting decisions. For the Umpqua River, the Phase I assessment was completed by the USGS in 2009 (O'Connor and others, 2009). Among the findings from this preliminary assessment of gravel transport and historical changes to channel conditions was that the Umpqua River was in a "long-term (over time scales of thousands of years) state of incision" and that the extensive presence of in-channel bedrock indicated that the main stem Umpqua River was historically, and presently is, sediment supply limitedmeaning that the transport capacity of the channel (the amount of sediment the channel could, theoretically, transport given its geomorphic and hydrologic characteristics) probably exceeds the volume of sediment entering the river system.
These findings prompted the interagency team to consider permitting of future in-stream gravel extraction subject to the completion of a more extensive Phase II analysis consisting of data acquisition and analysis aimed at:

1. Assessing planform changes to the Umpqua River, as well as the semi-alluvial portions of the North Umpqua and South Umpqua Rivers;

2. Determining spatial and temporal trends in bed-material flux; and

3. Evaluating linkages between sediment source areas in the upper basin and channel conditions along lower reaches of the main stem Umpqua River.

\section{Locations and Reporting Units}

Analyses and results are presented in SI (metric) units, except for bed-material flux values, which are presented in terms of mass in metric tons, which is equivalent to the SI unit megagram. Conversions to English units are provided in the report front matter. To convert between sediment mass and volume, we used an in situ bulk density value of 2.1 metric tons $/ \mathrm{m}^{3}$ on the basis of measurements conducted by Milhous (2001) and reported in Bunte and Abt (2001).

Locations along the channel are referenced to river kilometers (RKM) measured along the channel centerline from the mouth of the Umpqua River and continuing upstream along the South Umpqua River, as mapped from orthoimagery acquired in summer 2005 by the National Agriculture Inventory Program (NAIP). These distances do not correspond exactly with river miles (RM) shown on current USGS quadrangle maps. Measured from the same orthoimagery, river kilometers for the North Umpqua River (NURKM) begin at the confluence of the North Umpqua and South Umpqua Rivers, and continue upstream along the centerline of the North Umpqua River.

To avoid ambiguity due to channel shifting, locations and analyses for the study area are referenced to a flood-plain kilometer (FPKM) centerline, measured from the river mouth along the centerline of the Holocene flood plain upstream along the main stem Umpqua and South Umpqua Rivers (fig. 1). This flood-plain reference frame provides a static template from which to consider temporal changes in channel morphology and is not intended for use as a regulatory or flood-hazard tool. In 2005, approximately $179.5 \mathrm{~km}$ of river channel lay along $169 \mathrm{~km}$ of the main stem Umpqua River flood plain and $123.4 \mathrm{~km}$ of river channel were within $106 \mathrm{~km}$ of flood plain flanking the South Umpqua River. The North Umpqua flood-plain kilometer (NUFPKM) centerline begins at the mouth of the North Umpqua and extends $45 \mathrm{~km}$ along the North Umpqua River valley bottom, containing $47 \mathrm{~km}$ of river channel in 2005. 
Prominent landmarks and locations along the main stem Umpqua River include the mouth of Umpqua River near Winchester Bay FPKM 0 (RKM 0), the head of tide near Scottsburg at FPKM 40 (RKM 44), and the confluence of the North Umpqua and South Umpqua Rivers FPKM 169 (RKM 179.4). Major landmarks on the South Umpqua River include the city of Roseburg at FPKM 182 (RKM 197), and the mouth of Cow Creek at FPKM 230.9 (RKM 256). On the North Umpqua River, Winchester Dam is located at NUFPKM 10.2 (NURKM 11.3). Numerous gravel bars are referenced in this report, some of which have place names derived from USGS topographic maps and gravel mining permits, whereas others were assigned informal names during this study using nearby place names.

\section{The Umpqua River}

The Umpqua River drains 12,103 km² of western Oregon, heading in the Cascade Range and Klamath Mountains before traversing the Coast Range and entering the Pacific Ocean through Winchester Bay at Reedsport (ig. 1). The Umpqua River begins $179 \mathrm{~km}$ from its mouth at the confluence of the
North and South Umpqua Rivers near the city of Roseburg. The main tributaries of the main stem Umpqua River and their drainage areas are the Smith River $\left(961 \mathrm{~km}^{2}\right)$, Elk Creek $\left(756 \mathrm{~km}^{2}\right)$, and the Calapooya Creek (637 km²) (figs. 1 and $\underline{3}$ ).

The North Umpqua River drains 3,520 km², with headwaters in the High Cascades. Major tributaries and their drainage areas include the Little River $\left(533 \mathrm{~km}^{2}\right)$ and Steamboat Creek $\left(425 \mathrm{~km}^{2}\right)$, both located upstream of the study area. The upper North Umpqua River is noteworthy for its scenery and native fish populations, with approximately $55 \mathrm{~km}$ of the channel between Soda Springs Powerhouse and Rock Creek designated as a Wild and Scenic River. The South Umpqua River drains the northern Klamath Mountains and part of the Western Cascades. At its confluence with the North Umpqua River, the South Umpqua River has a drainage area of $4,665 \mathrm{~km}^{2}$. The main tributaries in the study area and their drainage areas are Lookingglass Creek (417 km²), Myrtle Creek $\left(308 \mathrm{~km}^{2}\right)$, Cow Creek $\left(1,292 \mathrm{~km}^{2}\right)$, and Jackson Creek $\left(490 \mathrm{~km}^{2}\right)$ (figs. 1 and $\left.\underline{3}\right)$.

The Umpqua River basin contains two federally designated wilderness areas, the Boulder Creek Wilderness in the North Umpqua River subbasin, and the Rogue-Umpqua Divide Wilderness in the South Umpqua River subbasin.

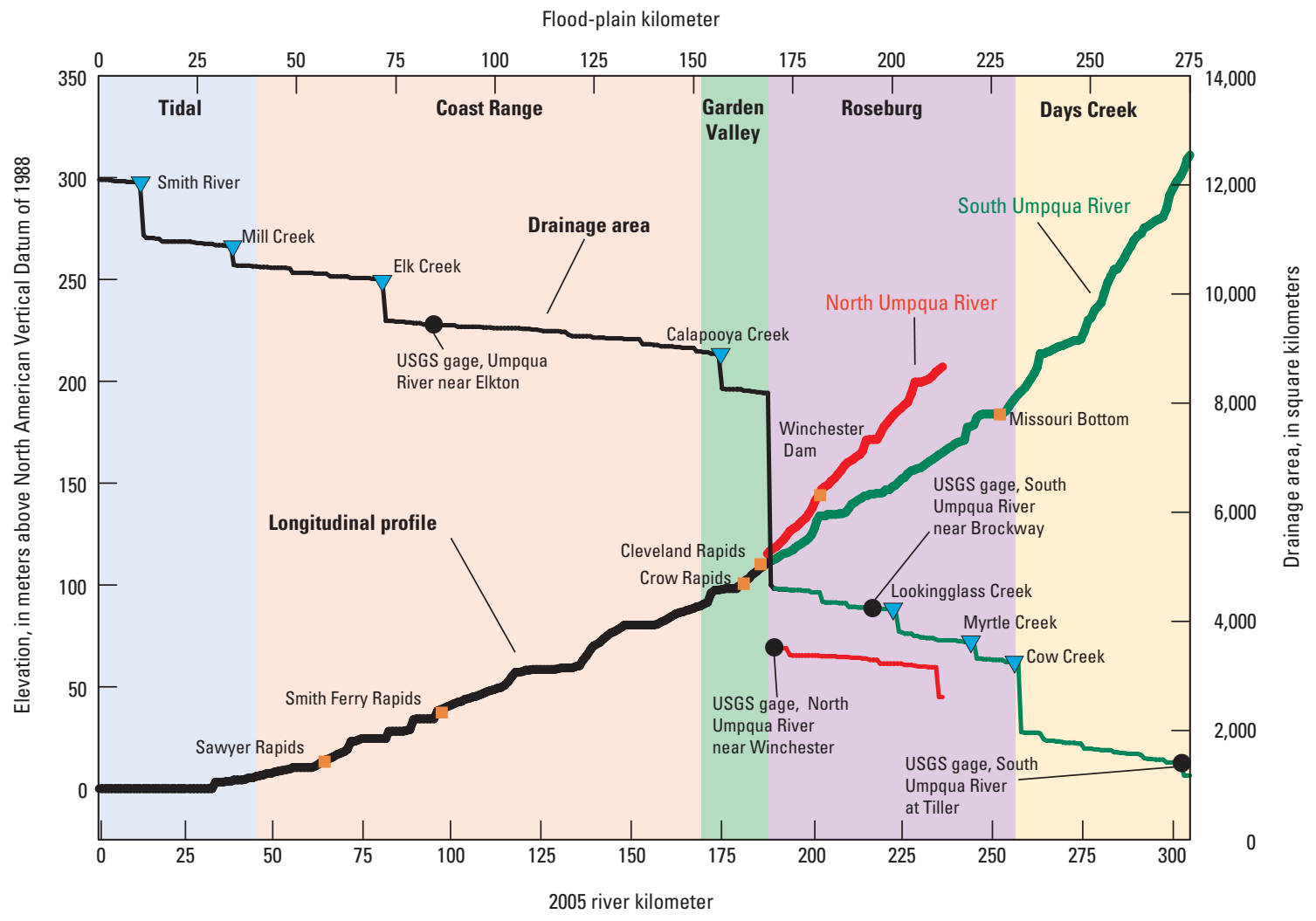

Figure 3. Longitudinal profile and cumulative drainage area of the Umpqua River basin, Oregon. 


\section{Geography and Geology}

The drainage basin is flanked to the north by the Siuslaw and Willamette River basins, to the east by the Deschutes and Klamath River drainages, and to the south by the Rogue and Coquille River basins. The basin has its headwaters in the Cascade Range, is bounded on the south by the Klamath Mountains, and transects the Coast Range before entering the Pacific Ocean (fig. 1).

The Umpqua River basin can be divided into five distinctive geomorphic provinces (fig. 1), each of which has a unique physiography. The North Umpqua River originates in the predominantly low-relief High Cascades province, where highly permeable Pliocene and Quaternary lava flows result in low rates of surface-water runoff and sediment transport (Jefferson and others, 2010).

Downstream of the High Cascades province, the North Umpqua River drains parts of the steeply dissected Western Cascades province, where the South Umpqua River has its headwaters. The weathered Tertiary volcanic rocks of the Western Cascades support higher rates of runoff and erosion than the High Cascades terrain, and mass wasting processes are a dominant mechanism of hillslope sediment production (Stillwater Sciences, 2000).

Downstream of the Western Cascades province, the South Umpqua River enters the Klamath Mountains province near Tiller at FPKM 281. The rugged terrain of the Klamath Mountains is underlain by a Cretaceous and Jurassic accretionary complex composed of weakly to intensely metamorphosed sedimentary, volcanic, and intrusive igneous rocks, primarily of Early Cretaceous and Jurassic age (Ramp, 1972; Wells and others, 2001). The Klamath Mountains are the source of several gravel-rich rivers in southern Oregon and northern California, including the Chetco and Smith Rivers (Wallick and others, 2010; MFG, Inc. and others, 2006).

The South Umpqua River leaves the Klamath Mountains and enters the Paleocene and Eocene marine volcanic sedimentary rocks of the Coast Range province at about FPKM 200. Similarly, the North Umpqua River leaves the Western Cascades at NUFPKM 45 and enters the Coast Range province. Both rivers first flow through the predominantly volcanic rocks of the Siletz River Volcanics before entering the soft sandstones and siltstones of the Umpqua Group near their confluence at FPKM 170 (Wells and others, 2001). From there, the Umpqua River meanders northwestward for about $20 \mathrm{~km}$ through Coles and Garden Valleys before bisecting the higher portion of the Coast Range within a narrow valley trending northwest for $145 \mathrm{~km}$. For this stretch, the river follows large meanders primarily incised into soft marine sediment of the Tyee and Elkton Formations (Ramp, 1972). Approximately $16 \mathrm{~km}$ from its mouth, the lower Umpqua River exits the Coast Range and flows through a coastal plain to the Pacific Ocean.

The main stem Umpqua River is locally flanked by flood-plain and terrace deposits within its entrenched meandering course through the Coast Range (Personius, 1993; Personius and others, 2003), reflecting episodes of river aggradation in conjunction with overall incision of the river during the Quaternary period. The youngest terrace, forming a surface 2-15 m above river level, is apparently associated with a period of enhanced gravel transport and channel aggradation about 10,000 years before present (Personius, 1993; Personius and others, 2003), although this surface is locally capped by younger deposits and probably was inundated by a large flood in December 1964. This episode of aggradation broadly correlates with aggradation of several Cascade Range rivers draining into the Willamette River valley (O'Connor and others, 2001; Wampler, 2004). Even higher surfaces are locally preserved, including some reaching $200 \mathrm{~m}$ above the present river level. One such surface at FPKM 70 is $41 \mathrm{~m}$ above present river level and has a thermoluminescence age of $116 \pm 20$ thousand years ago (ka) (Personius, 1993; Personius and others, 2003), indicating a long-term valley incision rate of 0.3 to $0.4 \mathrm{~mm} / \mathrm{yr}$.

The lower Umpqua River valley, particularly along the lowermost $40 \mathrm{~km}$, has been strongly affected by the $130 \mathrm{~m}$ of sea-level rise after the culmination of the last maximum glacial period 18,000 years ago. Along the Oregon coast, rising sea levels have flooded river valleys incised during low stands of sea level, creating estuaries now extending inland from the coast. This is the case for the Umpqua River, as well as for the Smith River, which joins the Umpqua River at FPKM 14 and is tidally affected for its lower $40 \mathrm{~km}$ (Personius, 1993). With the onset of sea-level rise, and especially during the last 2,000 years of relatively stable sea level, these estuarine reaches have been filling with fluvial sediment (Komar, 1997, p. 30-32), but for rivers such as the Umpqua and Smith Rivers, the low gradient (fig. 3 ) and far upstream propagation of tidal influence indicates that the sediment supply has not matched Holocene sea-level rise and that these rivers have not yet attained a graded profile to the coast. Because of the low gradients in the downstream reaches of the Umpqua and Smith Rivers, coarse bed material probably is not transported through these reaches to the Pacific Ocean. 


\section{Hydrology}

Information on basin hydrology derives from USGS streamflow-measurement records in the basin extending discontinuously back to 1905. Many of these data are available from the USGS (U.S. Geological Survey, 2010b), with some synthesis provided by Jones and Stearns (1930). The mean annual flow of the Umpqua River near Elkton at FPKM 84.7 for $1955-2004$ is $210 \mathrm{~m}^{3} / \mathrm{s}$, which closely corresponds to the combined mean flows for the North Umpqua River at Winchester (NUFPKM 2.5; $106 \mathrm{~m}^{3} / \mathrm{s}$ ), and the South Umpqua River near Brockway (FPKM 195.3, $78 \mathrm{~m}^{3} / \mathrm{s}$ ) for the same period (fig. 4, table 1). Despite a contributing area 25 percent smaller than the South Umpqua River, the North Umpqua River supplies more than 50 percent of the water at Elkton (compared to 37 percent provided by the South Umpqua River), primarily because of a greater area of high-elevation terrain subject to orographically enhanced precipitation (fig. 1, table 1). This high terrain, associated with Quaternary volcanic rocks of the High Cascades province, also explains the much lower intra-annual flow variability of the North Umpqua River, where the mean January flow is only 6.7 times that of August. By contrast, the mean January flow for the South Umpqua River is 57 times greater than the mean August flow. The young volcanic uplands of the North Umpqua River headwaters have poorly integrated surface drainage networks and host large-volume groundwater systems, resulting in attenuated surface runoff and large spring complexes that maintain relatively high and steady summer flows. By contrast, the more dissected and older rocks of the Western Cascades and Klamath Mountains terrains underlying much of the South Umpqua River headwaters generate flows that more quickly respond to episodes of precipitation and drought (Jones and Stearns, 1930).

Peak flows in the Umpqua River basin typically derive from winter frontal systems, with the largest flows resulting from regional rain-on-snow events. The peak of record for the South Umpqua, North Umpqua, and main stem Umpqua Rivers was in late December 1964, when 7,505 m³/s was reported for the main stem near Elkton, and 4,250 and $3,540 \mathrm{~m}^{3} / \mathrm{s}$ were reported for the North Umpqua River at Winchester and South Umpqua River near Brockway, respectively (table 1). The December 1964 flood probably was the largest since the rain-on-snow flood of 1861. The 2-year recurrence-interval flow is about $1,256 \mathrm{~m}^{3} / \mathrm{s}$ for the North Umpqua River near Winchester, 1,292 m³/s for the South Umpqua River at Brockway, and 2,660 $\mathrm{m}^{3} / \mathrm{s}$ for the main stem Umpqua River at Elkton (table 1).
At least two smaller episodes of widespread flooding have occurred in recent decades. From November 1996 through January 1997, a series of storms caused extensive regional flooding, resulting in three distinct periods of high flows in the Umpqua River basin (fig. 4). Most stream gages in the South Umpqua River basin, as well as the Elkton gage on the Umpqua River, had their highest flows during December 4-9, 1996, but the largest flows for the North Umpqua gages were about 2 weeks earlier on November 18, 1996 (table 1; Risley, 2004). Heavy rains in late December 1996 led to a third period of high flows during January $1-2,1997$. These high flows triggered numerous landslides, but the discharges for this flood were lower than for the November and December 1996 floods (Risley, 2004). The peak discharges for the November-December 1996 floods ranged from 5- to 10-year recurrence-interval flows at most sites, except for the Tiller gage on the South Umpqua River, where discharge was approximately similar to the 30-year recurrence interval event (table 1, fig. 5). A flood peaking on December 31, 2005, and continuing into early January 2006, was similar in magnitude to peak flows from the winter of 1996-97 (table 1).

Since the early 1950s, flow has been regulated by Pacific Power hydroelectric projects on the North Umpqua River, which include eight developments in the upper basin (fig. 1). These dams only minimally affect peak flows because they have limited storage, and much of their contributing area lies in the groundwater-dominated High Cascades terrain (Stillwater Sciences, 1998). For example, within the bypass reaches of these hydroelectric dams, the 1.5-year recurrence interval flood has been reduced by 15-30 percent, but larger floods (greater than 5-year recurrence interval) are unchanged (Stillwater Sciences, 1998).

In the South Umpqua River basin, Galesville Reservoir was constructed in the upper Cow Creek basin in 1985 to reduce flooding along the lower reaches of Cow Creek. Although Galesville Reservoir almost certainly has a pronounced effect on peak flows on Cow Creek, peak flows farther downstream on the South Umpqua River near Brockway did not show a marked decline following dam construction (fig. 5). It is unlikely that either Galesville Reservoir or the North Umpqua hydroelectric dams strongly influence peak flows as far downstream as the USGS gage near Elkton on the Umpqua River because they control only a small portion of the total drainage-area runoff at this gage (fig. 3). 


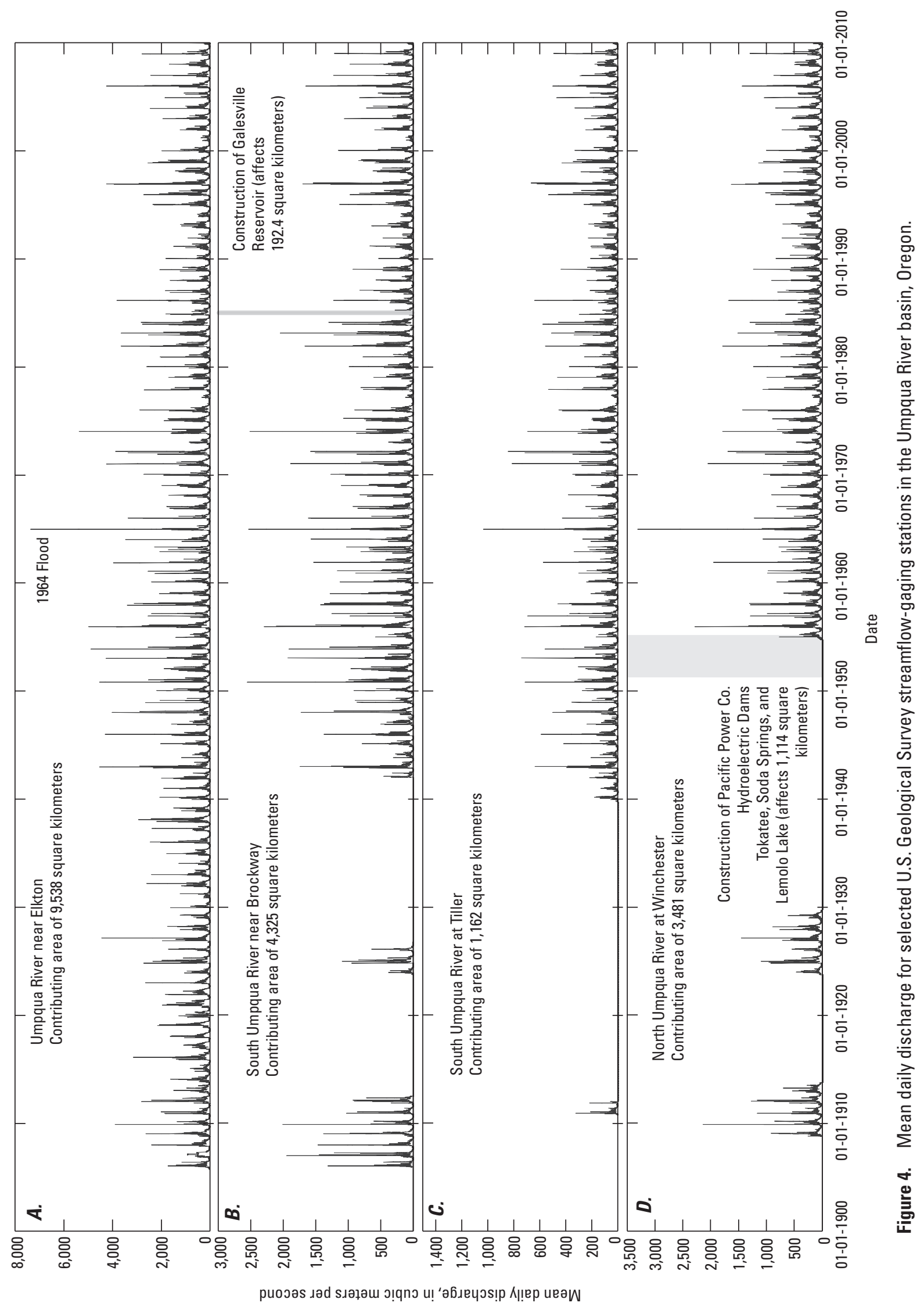




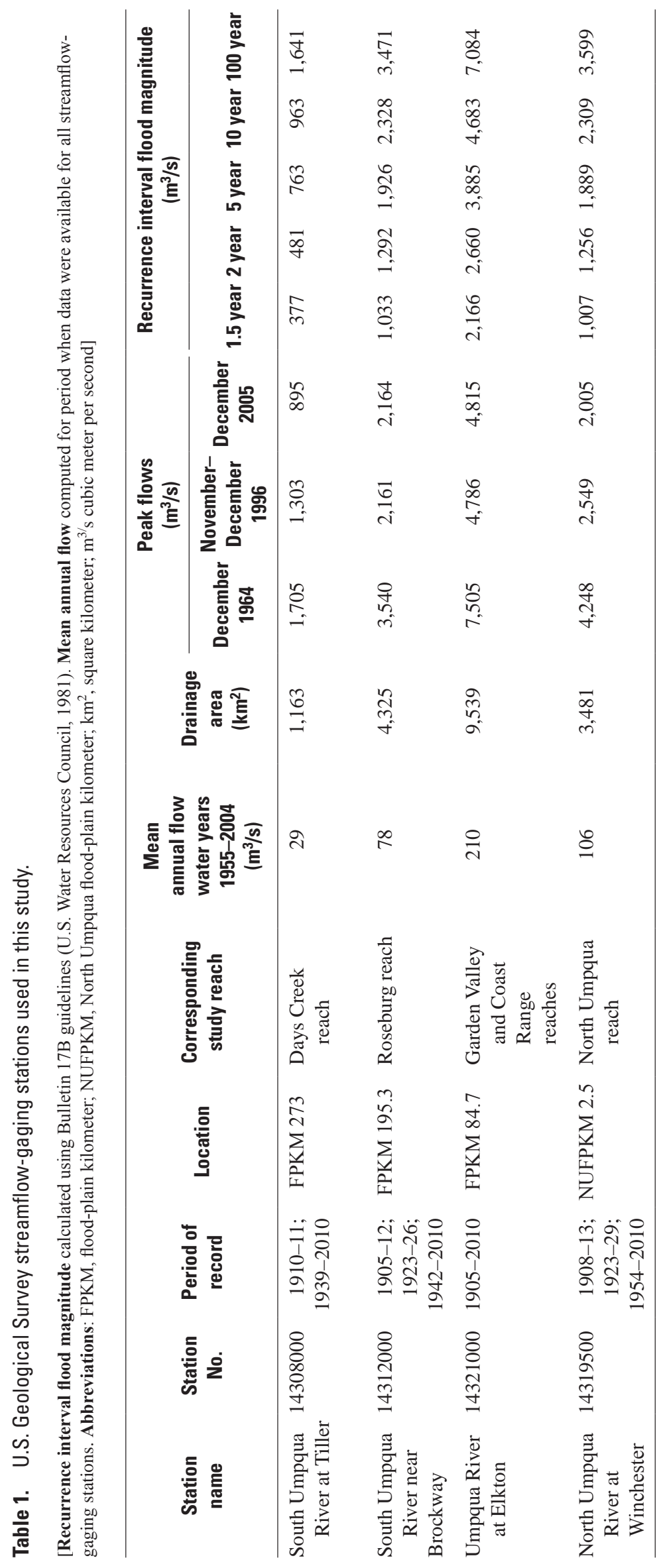




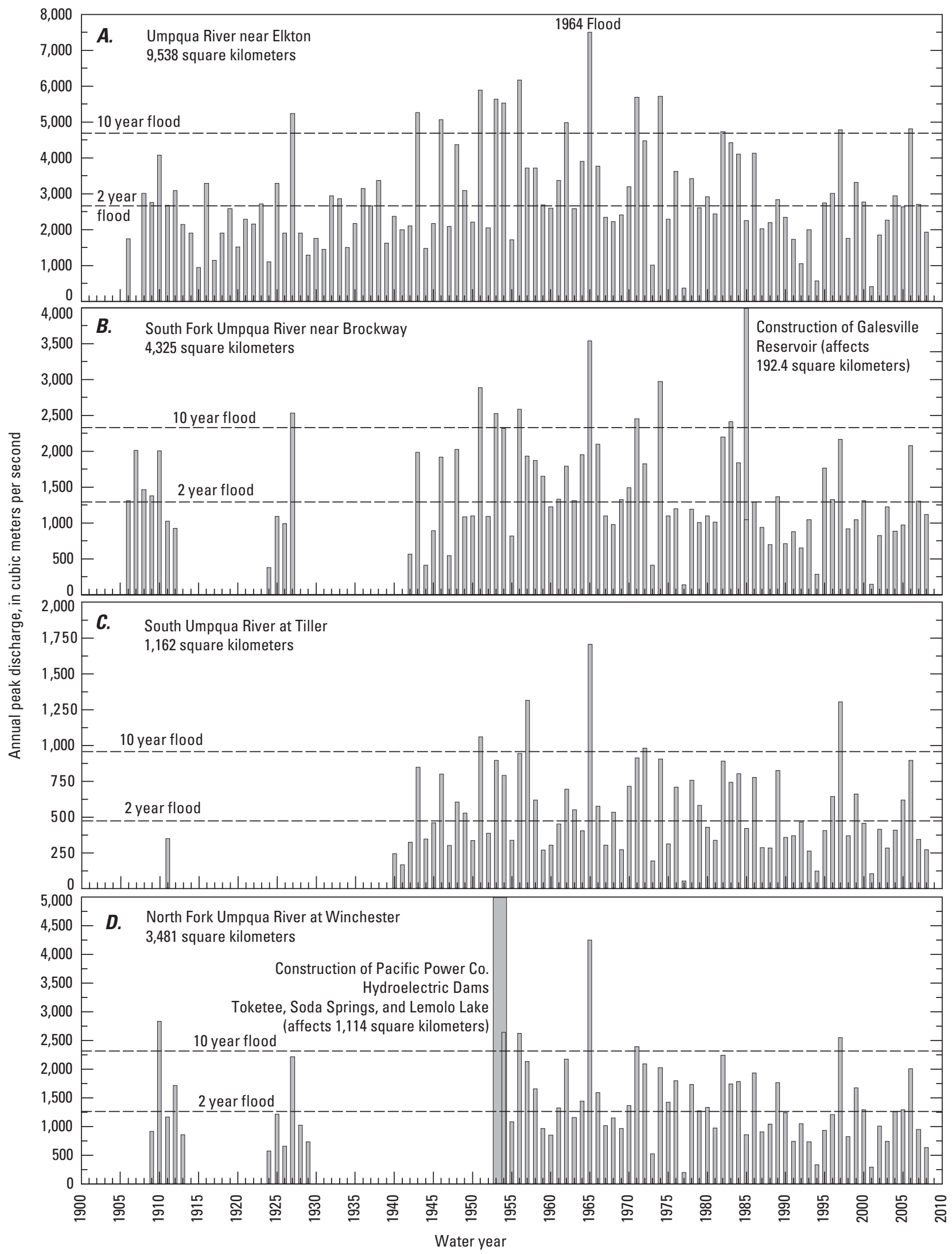

Figure 5. Annual peak discharge for selected U.S. Geological Survey streamflow-gaging stations in the Umpqua River basin, Oregon. 
Because channel morphology and bed-material transport is strongly affected by flood magnitude, streamflow records at 11 USGS streamflow-gaging stations in the Umpqua River basin were examined to evaluate temporal trends in peak flows (table 2). Although more than 70 streamflow and crest stage stations have historically been operated in the basin, only 11 had records extending at least 25 years with minimal flow regulation (defined here as basins where less than 10 percent of the contributing area is regulated by dams or bypass canals). With the exception of the Umpqua River near Elkton, most records begin in the 1940s or 1950s. For most of these sites, peak flows had a decreasing trend during the period of analysis. On the basis of a two-tailed nonparametric Kendall's tau test with a 5-percent level of significance $(p<0.025$ and $p>0.975)$ the trend was statistically significant for 4 of the
11 sites, including West Fork of Cow Creek near Glendale, Lookingglass Creek at Brockway, North Umpqua River at Winchester, and Calapooya River near Oakland (table 2). The South Umpqua River near Brockway site had a $p$ value of 0.03 , which was nearly significant (table 2). This decreasing trend in peak flow mainly is due to long-term climate cycles. Most of these gaging stations began operating during the cool, wet period along the Oregon coast from 1946 to 1976; however, since 1976 the climate has been warmer and drier, although some shorter periods of cool/wet years have occurred since 1976 (Oregon Climate Service, written commun., 1999). The Umpqua River gaging station near Elkton has the longest flood record (104 years), resulting in this record spanning multiple dry (including the 1920s and 1930s) and wet cycles and thereby having no significant overall trend.

Table 2. U.S. Geological Survey streamflow-gaging stations in the Umpqua River, Oregon, used in peak flow analysis.

[ $\boldsymbol{p}$ valuefrom two-tailed, nonparametic Kendall's tau test to evaluate whether historical declines in peak flows are statistically significant; significance level set at 5 percent $(p<0.025$ or $p>0.975)$. Abbreviations: $\mathrm{km}^{2}$, square kilometer; $\mathrm{m}$, meter; $<$, less than; $>$, greater than]

\begin{tabular}{|c|c|c|c|c|c|c|c|}
\hline $\begin{array}{l}\text { Station } \\
\text { name }\end{array}$ & $\begin{array}{l}\text { Station } \\
\text { No. }\end{array}$ & $\begin{array}{c}\text { Period of } \\
\text { analysis } \\
\text { (water years) }\end{array}$ & $\begin{array}{l}\text { Number } \\
\text { of years }\end{array}$ & $\begin{array}{c}p \\
\text { value }\end{array}$ & $\begin{array}{c}\text { Drainage } \\
\text { area } \\
\left(\mathbf{k m}^{2}\right)\end{array}$ & $\begin{array}{c}\text { Gage } \\
\text { elevation } \\
\text { (m) }\end{array}$ & $\begin{array}{c}\text { Mean } \\
\text { basin } \\
\text { elevation } \\
\text { (m) }\end{array}$ \\
\hline South Umpqua River at Tiller & 14308000 & 1940-2009 & 70 & 0.29 & 1,163 & 302 & 978 \\
\hline Elk Creek near Drew & 14308500 & $1955-2009$ & 55 & 0.26 & 141 & 390 & 878 \\
\hline West Fork Cow Creek near Glendale & 14309500 & 1956-2009 & 54 & 0.02 & 225 & 310 & 738 \\
\hline Lookingglass Creek at Brockway & 14311500 & 1956-1987 & 32 & 0.00 & 409 & 165 & 418 \\
\hline South Umpqua near Brockway & 14312000 & $1942-2009$ & 68 & 0.03 & 4,325 & 141 & 698 \\
\hline $\begin{array}{l}\text { North Umpqua River above } \\
\text { Copeland Creek near Toketee Falls }\end{array}$ & 14316500 & 1950-2009 & 60 & 0.21 & 1,230 & 482 & 1,472 \\
\hline Steamboat Creek near Glide & 14316700 & 1956-2009 & 54 & 0.09 & 588 & 344 & 945 \\
\hline Little River at Peel & 14318000 & 1955-1989 & 35 & 0.08 & 458 & 252 & 860 \\
\hline North Umpqua River at Winchester & 14319500 & 1954-2009 & 56 & 0.01 & 3,481 & 114 & 1,006 \\
\hline Calapooya Creek near Oakland & 14320700 & $1956-1980$ & 25 & 0.01 & 544 & 113 & 415 \\
\hline Umpqua River near Elkton & 14321000 & 1906-2009 & 104 & 0.88 & 9,539 & 28 & 747 \\
\hline
\end{tabular}




\section{Description of Study Area}

The study area encompasses the downstream semi-alluvial sections of the North Umpqua and South Umpqua Rivers and the entire main stem Umpqua River (fig. 1, table 3). For both the North and South Umpqua Rivers, the semi-alluvial sections begin where the rivers exit the mountainous headwaters, widen, and flow on a mixed bed of bedrock and alluvium flanked by variable widths of flood plain and terraces. For the North Umpqua River, this transition to a dominantly alluvial character approximately corresponds with the confluence of the Little River at NUFPKM 44.8 (flood-plain kilometers for the North Umpqua River are measured with respect to the confluence with the South Umpqua River). Downstream of the Little River confluence, the North Umpqua River generally is $60-85 \mathrm{~m}$ wide and flows on a bed of sandstone and basalt, locally mantled by thin accumulations of sand and gravel. The average gradient from the Little River confluence to the confluence with the South Umpqua River is 0.00177 (table 3). In this reach, the North Umpqua River is flanked by a valley bottom typically less than $0.8 \mathrm{~km}$ wide formed of recent flood-plain deposits and small terrace remnants.

For the South Umpqua River, the confluence of Jackson Creek at FPKM 280.9 near Tiller approximately marks the transition from a confined mountain stream to a mixed alluvial and bedrock channel locally flanked by active gravel bars, flood-plain surfaces, and terraces. Between the junction of Jackson and Cow Creeks, the South Umpqua River flows generally westward with an average gradient of 0.00249 (table 3) and a width typically less than $45 \mathrm{~m}$. In this reach, the valley alternates between confined canyon reaches and sections as wide as $1.6 \mathrm{~km}$. Wider sections contain channel flanking gravel bars, flood plains, tributary fans, and terrace deposits. With the confluence of Cow Creek at FPKM 230.9, the drainage area of the South Umpqua River increases by about one-third and the channel widens to 60-120 m (fig. 3) as the river flows generally northward on an alternating bed of bedrock and alluvium for $76 \mathrm{~km}$ to the junction with the North Umpqua River. Within this reach, the average gradient is 0.001 as the South Umpqua River winds through canyons alternating with valleys as wide as $3.5 \mathrm{~km}$, and is locally flanked by gravel bars, flood plains, and terraces. The channel widens, and the number of gravel bars decreases for the $19 \mathrm{~km}$ of the main stem Umpqua River downstream of the confluence of the North Umpqua and South Umpqua Rivers. From FPKM 152 to about FPKM 40, the river flows within deep and narrow meanders incised through the Coast Range, with narrow flanking flood plains and terraces almost everywhere less than $0.8 \mathrm{~km}$ wide. The channel in this reach typically is $85-170 \mathrm{~m}$ wide and consists of long pools separated by bedrock rapids; the average gradient between FPKM 152 and the head of tide at FPKM 40 is 0.00073 (table 3). From FPKM 40 to the mouth, the Umpqua River progressively widens and is flanked by low flood plains, tidal marshes, and sand bars, especially downstream of the mouth of the Smith River at FPKM 14.

The overall physical setting, as well as the distribution of in-stream gravel-mining permits (Jo Ann Miles and Robert Lobdell, Oregon Department of State Lands, written commun., 2008), lends itself to delineation of valley reaches to help organize sediment-related issues, analyses, and findings (fig. 1, table 3). These reaches are, from downstream to upstream:

1. Tidal reach (fig. 6), between FPKM 0 and approximately 40 , distinguished by tidal influence, low gradients, expansive sediment deposits, and historical sand and gravel removal for navigation and commercial aggregate;

2. Coast Range reach (fig. 7), between approximately FPKM 40 and 152 , characterized by a confined valley with bedrock channel and few gravel deposits;

3. Garden Valley reach (fig. 8) of broad valleys, between where the Umpqua River enters the Coast Range at FPKM 152 and the confluence of the South Umpqua and North Umpqua Rivers at approximately FPKM 169, a relatively short reach with several historically mined gravel bars;

4. Roseburg reach (fig. 9) of the South Umpqua River, between the confluence with the North Umpqua River (FPKM 169) and the Cow Creek confluence at FPKM 231, where there are abundant gravel bars and several recently active in-stream gravel mining operations;

5. Days Creek reach of the South Umpqua River (fig. 10), between the Cow Creek confluence at approximately FPKM 231 and 275, which constitutes the uppermost semi-alluvial reach of the South Umpqua River; and

6. North Umpqua reach of the North Umpqua River (fig. 11) between NUFPKM 0 and the Little River confluence at NUFPKM 45 , a reach locally flanked by alluvial deposits but with no recent in-stream gravel mining. 
Table 3. Geomorphic and channel characteristics for reaches in the Umpqua River basin, Oregon.

[Abbreviations: FPKM, flood-plain kilometer; $\mathrm{km}^{2}$, square kilometer; m, meter; $\mathrm{m}^{2}$, square meter, $\mathrm{m}^{2} / \mathrm{m}$, meter squared per meter; $\mathrm{m}^{3} / \mathrm{s}$, cubic meter per second]

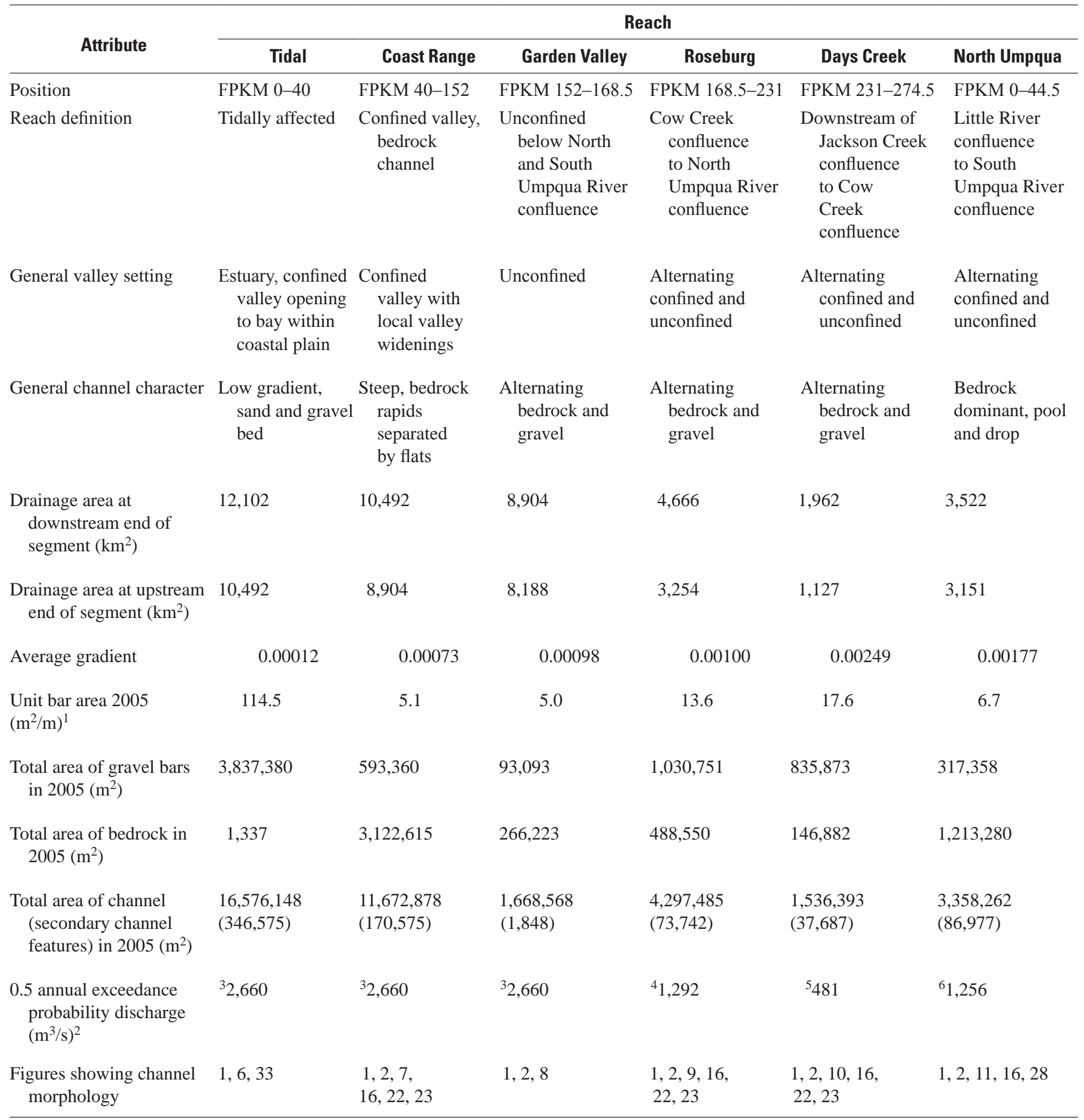

${ }^{1} 2005$ mapped bar area divided by reach centerline.

${ }^{2}$ Following Bulletin 17-B guidelines for gage record through water year 2008.

${ }^{3}$ U.S. Geological Survey streamflow-gaging station on Umpqua River at Elkton.

${ }^{4}$ U.S. Geological Survey streamflow-gaging station on South Umpqua River near Brockway.

${ }^{5}$ U.S. Geological Survey streamflow-gaging station on South Umpqua River at Tiller.

${ }^{6}$ U.S. Geological Survey streamflow-gaging station on North Umpqua River at Winchester. 


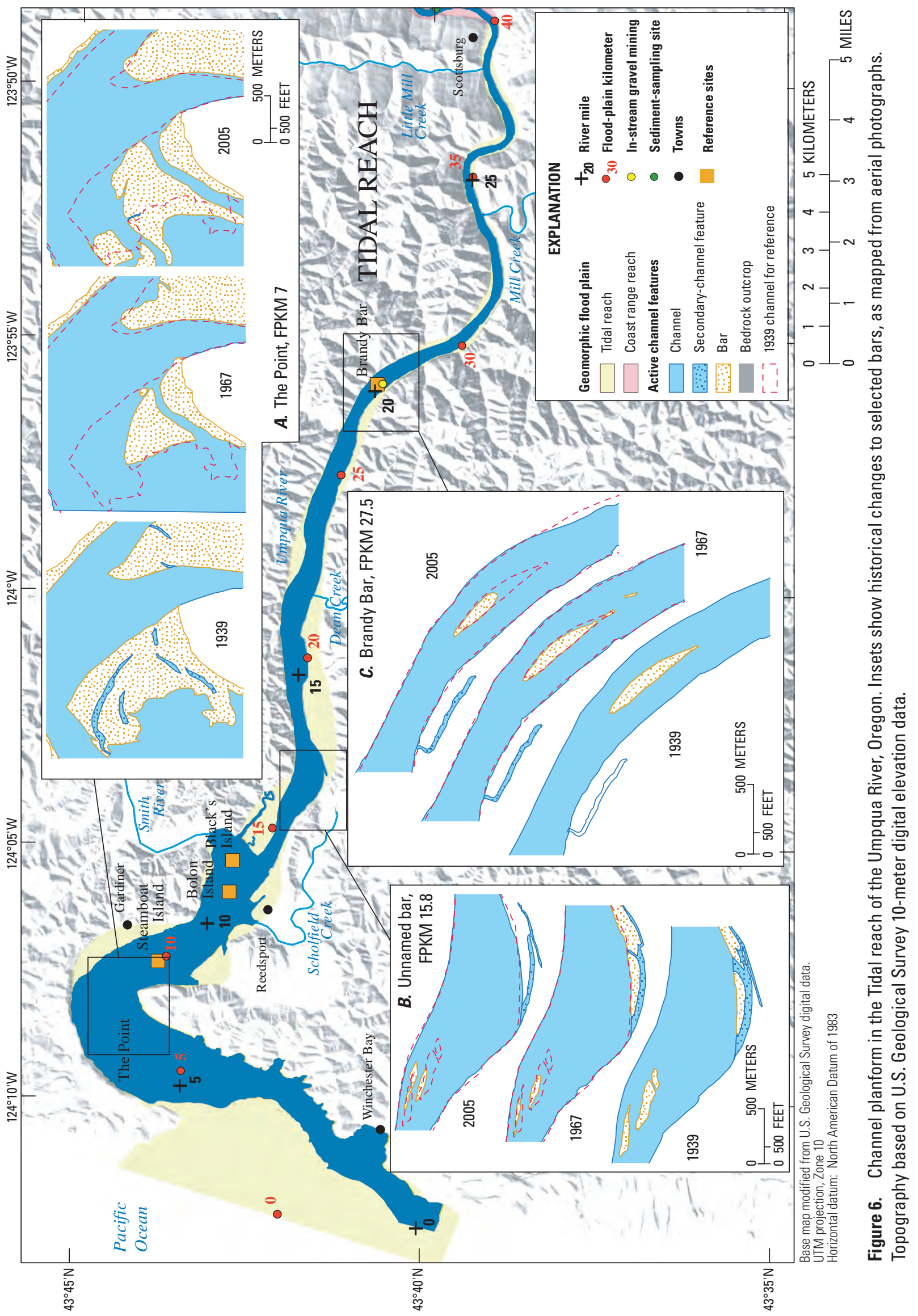




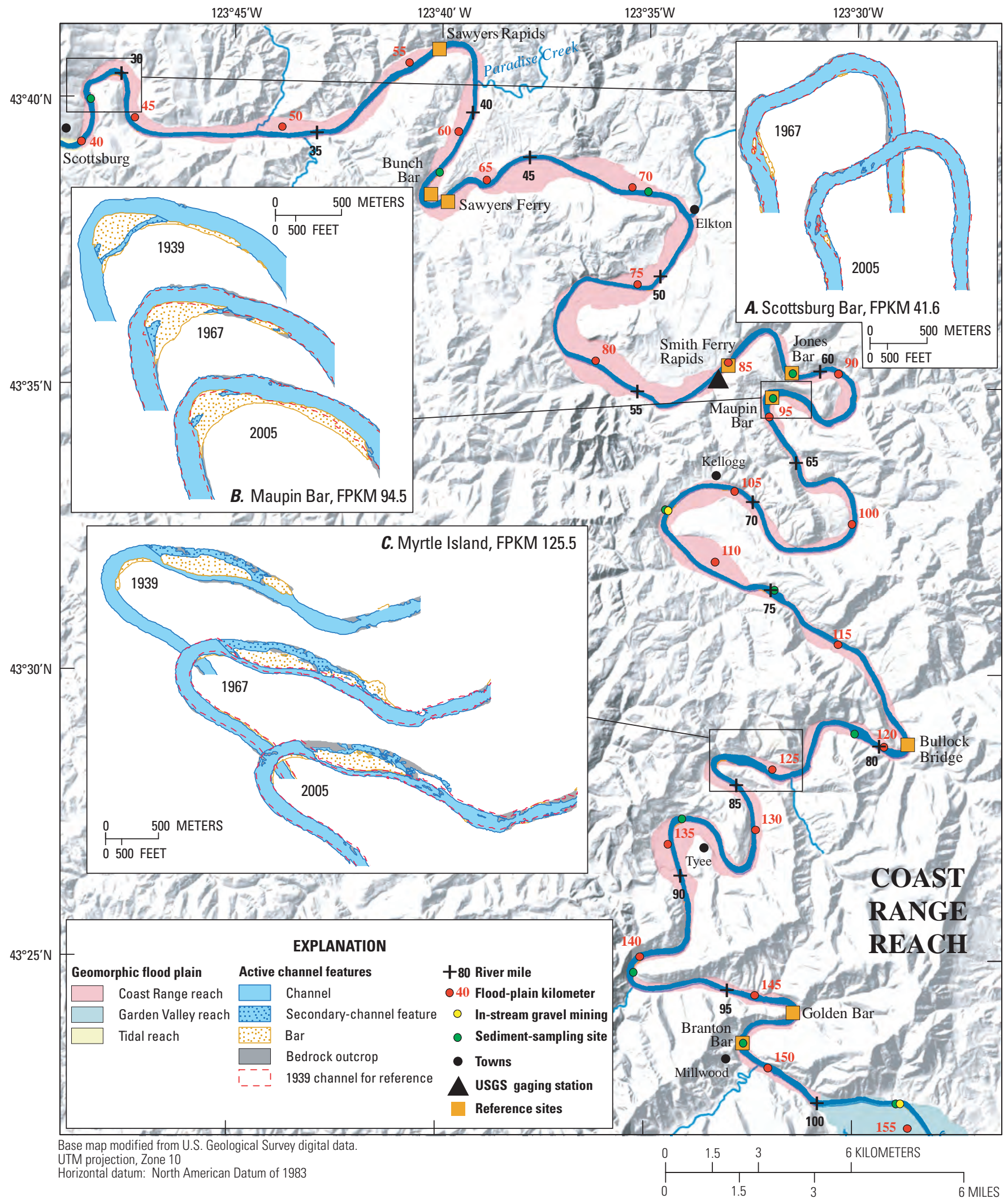

Figure 7. Channel planform in the Coast Range reach of the Umpqua River, Oregon. Insets show historical changes to selected bars, as mapped from aerial photographs. Topography based on U.S. Geological Survey 10-meter digital elevation data. 


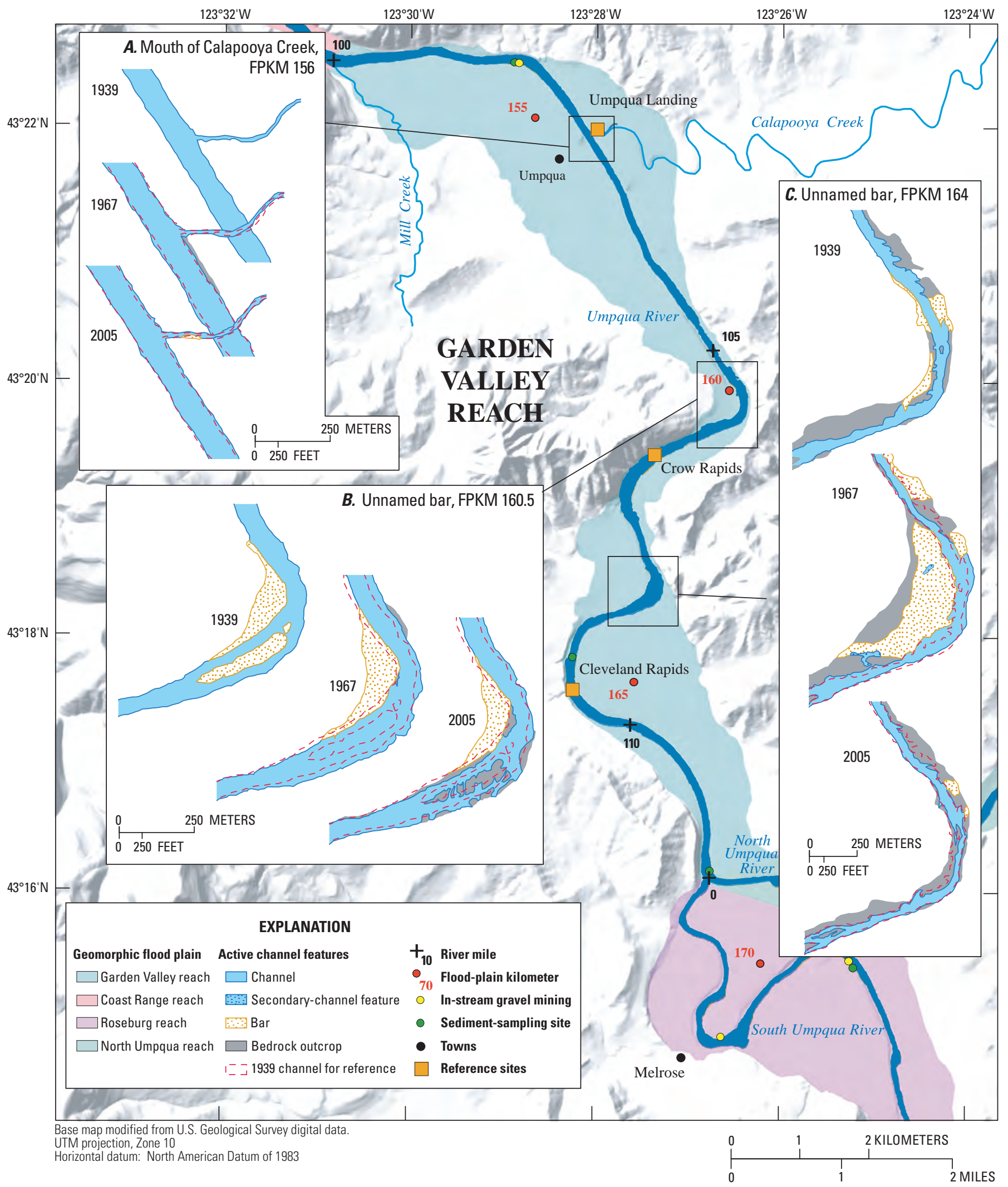

Figure 8. Channel planform of the Garden Valley reach of Umpqua River, Oregon. Insets show historical changes to selected bars, as mapped from aerial photographs. Topography based on U.S. Geological Survey 10-meter digital elevation data. 


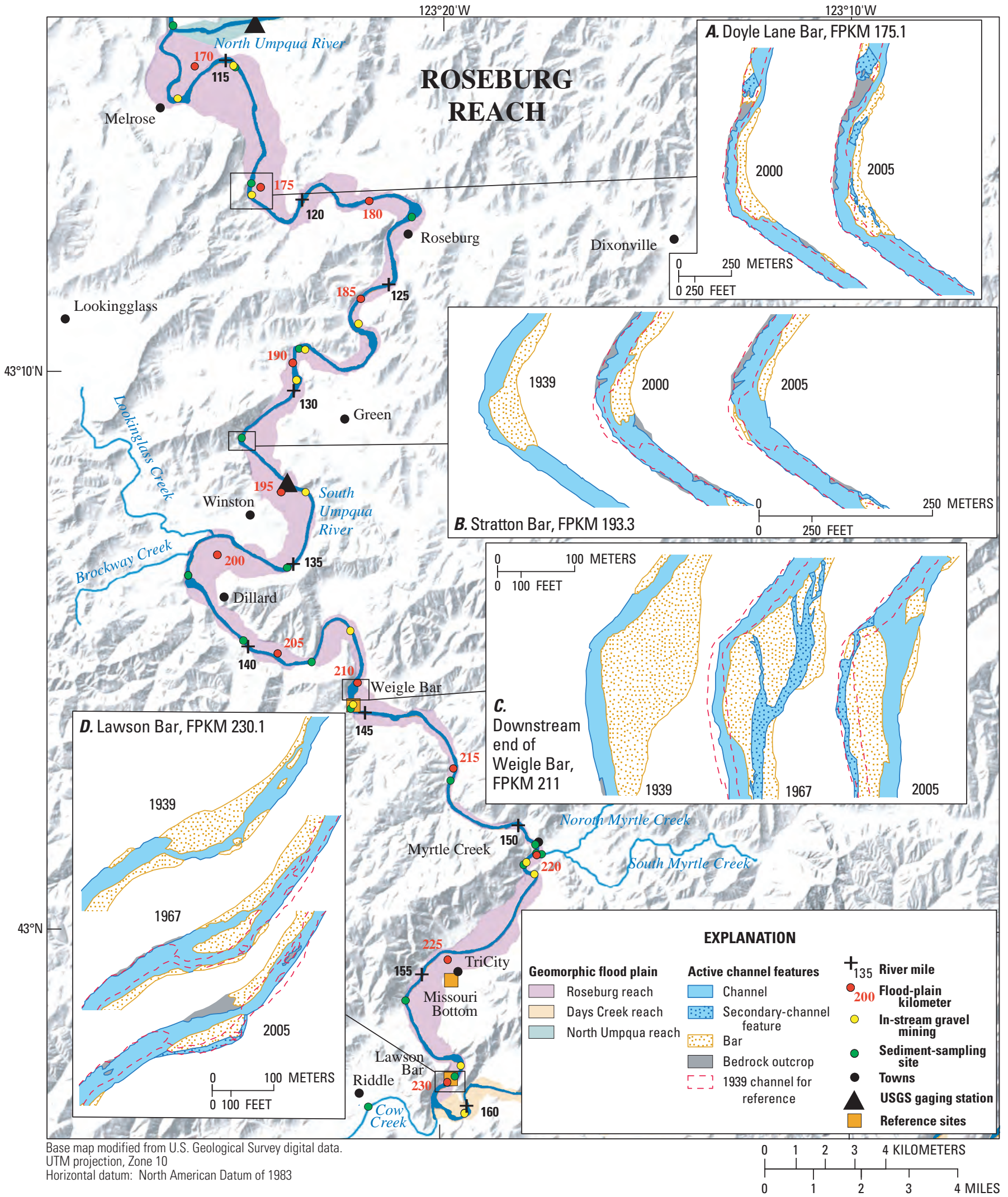

Figure 9. Channel planform of the Roseburg reach of the South Umpqua River, Oregon. Insets show historical changes to selected bars, as mapped from aerial photographs. Topography based on U.S. Geological Survey 10-meter digital elevation data. 


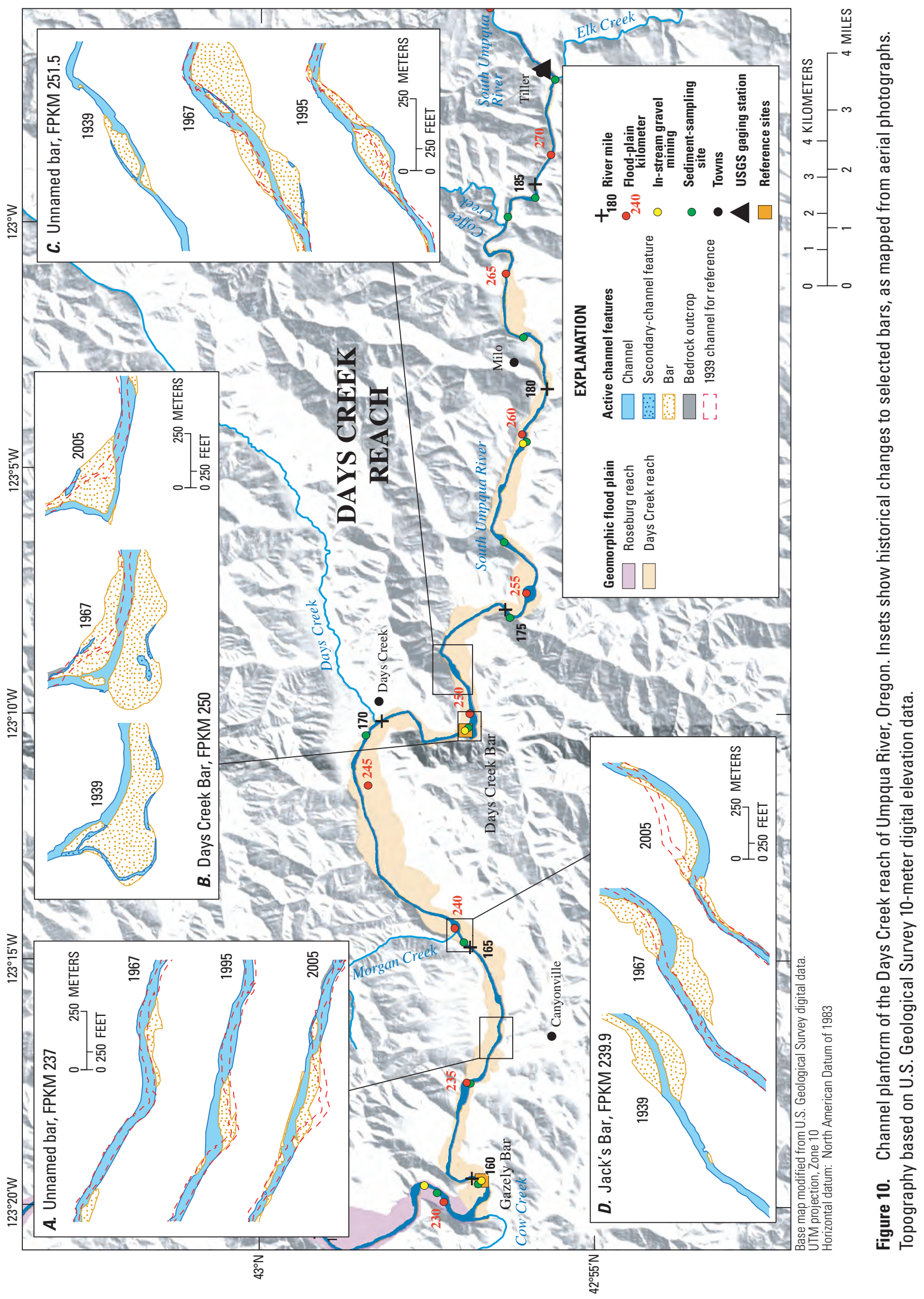




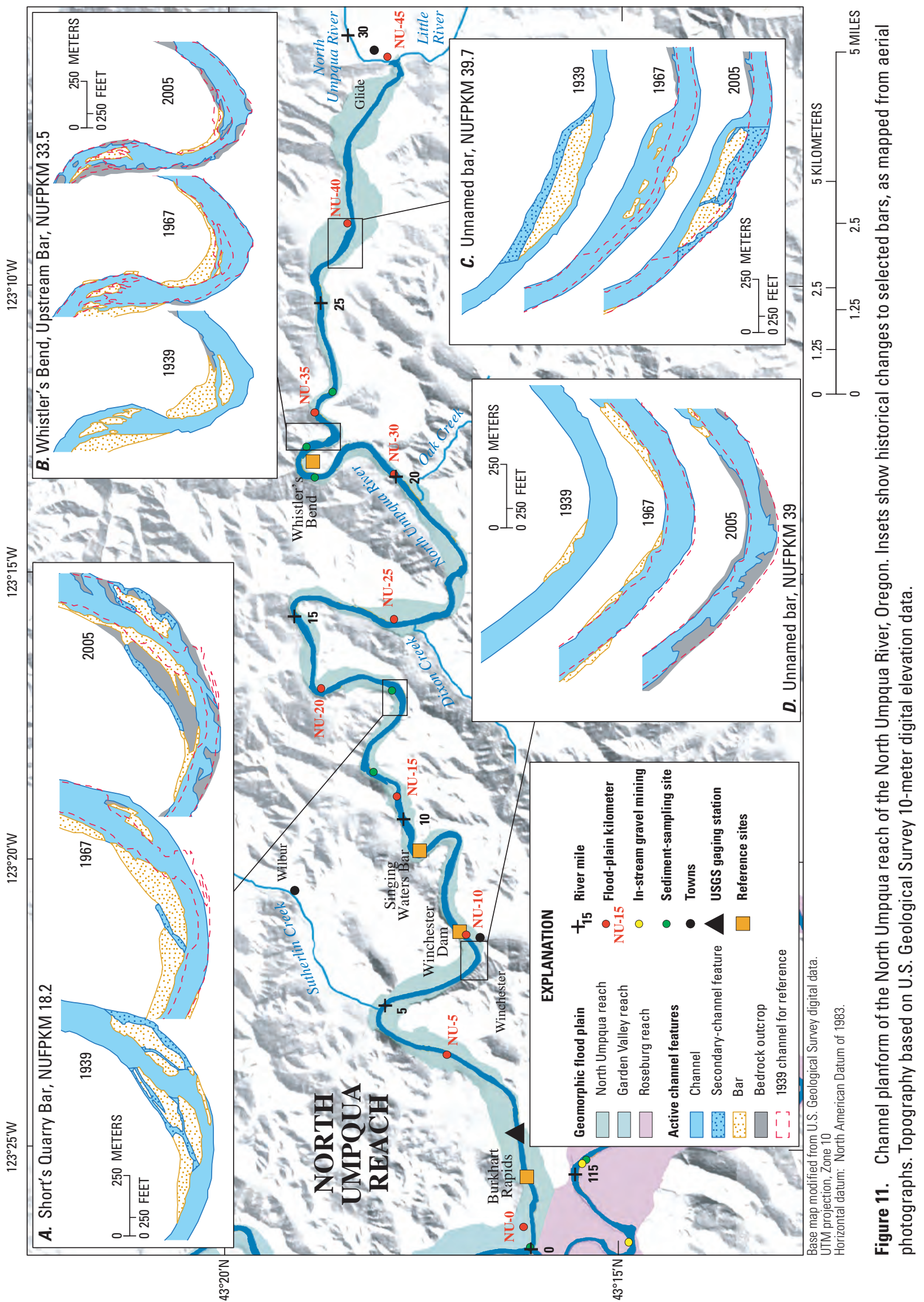




\section{Historical Descriptions of the Umpqua River}

We reviewed several Umpqua River basin historical documents (many also summarized by Beckham [1986], Winterbotham [1994], and Markers [2000]) for observations and accounts pertinent to channel conditions. The most useful of these are reports of early exploration and navigation surveys documenting channel characteristics at first EuropeanAmerican settlement. Accounts of historical land-use activities are also relevant to understanding historical and present channel conditions. Abundant archival photographs, at the Douglas County Historical Society and elsewhere, locally document channel conditions as far back as circa 1900. A primary conclusion from inspection of these historical sources is that gravel was scarce in many reaches of the Umpqua River. This is particularly evident for the Coast Range reach of the main stem Umpqua River. For example, David Douglas, a botanist (and county namesake) accompanying an expedition of the Hudson's Bay Company, describes his October 16, 1826, evening activities at their camp near the present location of Elkton (Douglas, 1914, p. 223; FPKM 72.1; Coast Range reach):

I employed myself chopping wood, kindling the fire, and forming the encampment; and after, in the twilight, bathed in the river: course north-west; bed sandstone; ninety yards broad; not deep, but full of holes and deep chinks worn out by the water.

Similarly John Work, employed by the Hudson's Bay Company, describes following the main stem Umpqua River between Elkton and Scottsburg (FPKM 40) in his journal entry for June 8, 1834 (Scott, 1923): "No stones worth mentioning all the way: the river runs on a bed of soft slatey rock.” Two weeks later, on June 17, John Work was camping along the Umpqua River just downstream of the Calapooya Creek confluence (FPKM 156; Garden Valley reach) where he reported:

The Umquah here is about 150 yards wide \& runs over a rocky bottom of soft slatey rock \& is not very deep. A horse can ford it at present.

The most extensive early survey was by U.S. Army Engineers lieutenant R.S. Williamson in 1870 while investigating navigation possibilities. His report (U.S. House of Representatives, 1871) described the several bedrock rapids between Scottsburg and Roseburg and provided a general characterization of the river:

The average width of the river, when bankfull, appeared to be about 200 feet; but at its extreme low-water stage the water is divided at many places into half a dozen or more streams, varying in width from two to thirty feet, and separated from each other by walls of rock sometimes five or six feet in height. In passing through some of these narrow place[s] the velocity of the current was 400 feet per minute. At each of these rapids between the channel and the shore there is a bench of sandstone, generally flat, varying from two to five feet in height above the low-water mark, and averaging about seventy-five feet in width. During ordinary stages of the river this is covered with water. The river contains no sand-bars, its bottom being coarse gravel, on solid bed-rock; consequently any improvements which may be made to the river are likely to be permanent.

A subsequent survey in 1910 encompassing most of the Roseburg, Garden Valley, and Coast Range reaches by the Junior Engineer F.E. Leefe of the U.S. Engineer Office (U.S. House of Representatives, 1911) reiterates Williamson's findings:

In the stretch of river under examination between Roseburg and Scottsburg, a distance of 86 miles, the low water fall is about 465 feet. Throughout this distance the river at low water is a succession of rocky rapids with pools of quiet water between, of varying lengths and depths. The river flows over a rocky sandstone bottom much of the way, with many dangerous reefs and projections. With such a fall, averaging nearly $5 \frac{1}{2}$ per mile, the current is strong over the rapids at all stages.

Although sand and gravel accumulations are barely mentioned in many of these accounts of the South Umpqua and main stem Umpqua Rivers, except for noting their scarcity, some historical photographs show bars flanking the channel (fig. 12). We have found fewer early descriptions of the Days Creek reach of the South Umpqua River at the time of first exploration, but it too was apparently locally flowing on bedrock, at least near its downstream end, because in-channel potholes near the Cow Creek confluence were targets for gold miners in the 1850s (Beckham, 1986, p. 93).

Although no detailed surveys were conducted for the North Umpqua River, reports by the Wilkes Expedition on their 1841 overland trip between the Willamette Valley and San Francisco Bay (including geologist James Dwight Dana) state that the North Umpqua River ran on bedrock where they crossed it near the present location of Winchester (North Umpqua RM 7; Dana, 1849, p. 662). Similarly, Markers (2000, p. 133) noted:

The North Umpqua River has been pronounced, by experts in the driving of streams, to be the best driving stream in Oregon or Washington. It is singularly free from shifting sand bars and gravel shoals.... 


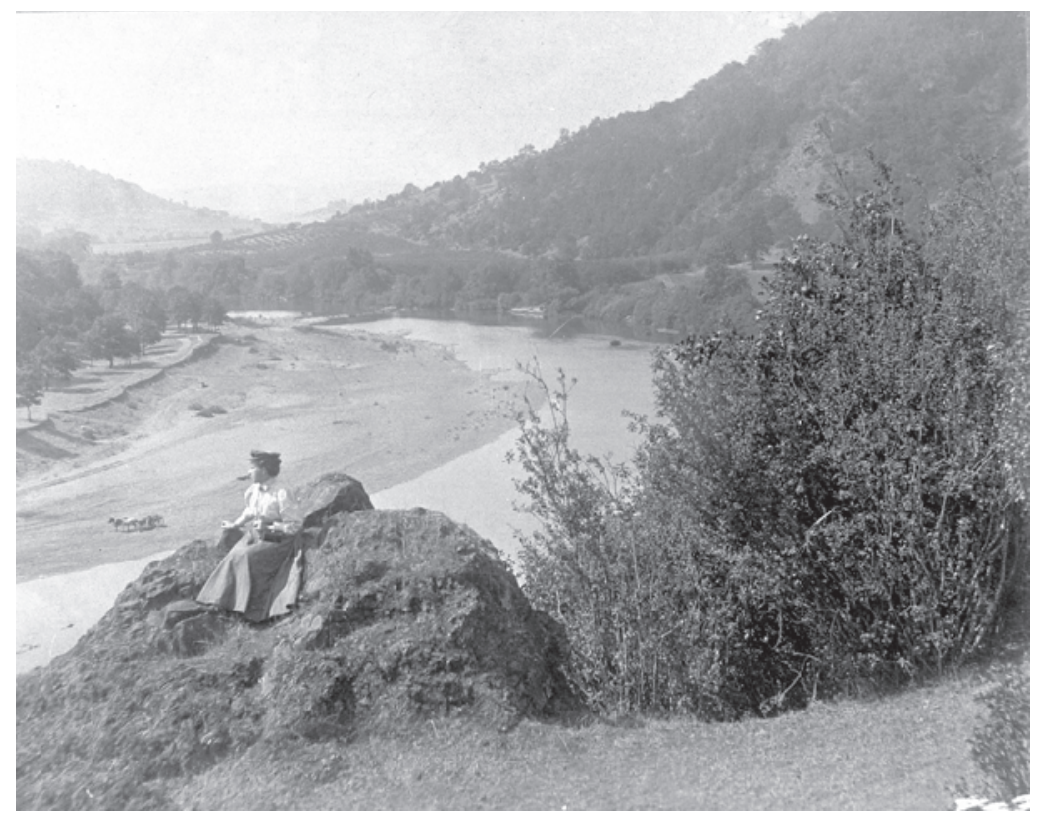

Figure 12. Circa 1890s, of the South Umpqua River upstream of Mount Nebo near Roseburg, Oregon. Photograph courtesy of Douglas County Museum (Photograph N5549a).

The character of the Tidal reach was distinctly different; drifting sand and gravel bars caused persistent navigation problems between the mouth and the head of tide at Scottsburg (FPKM 40), leading to multiple bathymetric surveys beginning in the late 18th century (summarized by Beckham, 1986, p. 149-152). These issues ultimately resulted in construction of the jetties and substantial and ongoing dredging of the lower channel. Shallow gravel bars near Brandy Bar (FPKM 27.5) also caused navigation hazards; this area ultimately became the reach of primary 20th and 21st century sand and gravel mining by Umpqua River Navigation Company and its successors.

\section{Land-Use and Landscape Disturbance in the Umpqua River Basin}

Although fur traders and early explorers entered the mouth of the Umpqua River basin in the late 18th century, European-American settlement of the basin did not fully commence until the mid-19th century following the passage of the Donation Land Act in 1850 and subsequent Federal programs (Beckham, 1986). The earliest immigrants to the basin claimed the fertile bottomlands and broad prairies of the central Umpqua River basin leaving more marginal ground, including rugged forest lands and flood-prone tributary valleys to later arrivals. These early settlement patterns are still evident today, as most of the basin's population lives in the wide valley bottoms in the incorporated areas of Roseburg, Winston, and nearby towns (Geyer, 2003b, 2003c, 2003d). The upper parts of the North Umpqua and South Umpqua River basins primarily are federally held forest lands, but the lower parts of these drainage basins mostly are privately owned, and the basins are managed for forestry and agriculture (Geyer, 2003a, 2003b, 2003c, 2003d). Nearly 70 percent of lands in the main stem Umpqua River basin (downstream of the confluence of North Umpqua and South Umpqua Rivers) are managed primarily for forestry, with the balance being for agriculture, residential, industrial, or other land uses (Oregon State University, 2010). 
Descriptions of historical land-use and landscape disturbance that have potentially affected channel and bed-material conditions are summarized by Beckham (1986), although watershed studies and other sources provide supplementary information. In the Umpqua River basin, the disturbances that are most likely to influence channel conditions and bed-material transport include navigational dredging, placer mining, in-stream gravel mining, impoundments for hydropower and flood control, and forestry and other land-use practices (table 4).

\section{Placer Mining}

Gold mining in the Umpqua River basin began in 1852 on the South Umpqua River near Riddle and in lower Cow Creek (Beckham, 1986, p. 225-226). The widespread placer mining on the South Umpqua River and its tributaries Olalla Creek (a tributary of Lookinglass Creek), Myrtle, Cow, and Coffee Creeks (Diller, 1914; Ramp, 1972) probably had the most significant effects on in-stream gravel conditions (figs. 9 and 10). All these drainages enter the South Umpqua River within the Roseburg and Days Creek reaches. Placer mining in the late 19th and early 20th centuries involved extensive excavation of alluvial terraces flanking the present watercourses, in places aided by elaborate hydraulic works (fig. 13). Beckham (1986, p. 93) noted the impact of these activities on the stream channels:

Mining generated terrible problems for the Indians. The cascade of debris down the creeks and rivers had calamitous impact on the fish runs: mining destroyed the spawning grounds by washing away the gravels and coating the river bottom with mud.

Such effects, as well as possible large inputs of gravel to South Umpqua tributaries, may still have implications for the present-day sediment conditions in the Umpqua River system.

\section{Umpqua River Gravel Mining}

Gravel bars in the Umpqua River basin have provided a local source of aggregate used in local road building and construction projects since the early 1900s. Although records describing mining practices, quantities, and locations prior to 2001 are scarce, anecdotal accounts from landowners and limited information on gravel mining permits (Oregon Department of State Lands, written commun., 2008) indicate that at least 17 sites along the South Umpqua and main stem Umpqua Rivers either had active permits for gravel removal or documented mining in recent decades.
Longtime residents and gravel operators report that the 1970s was a period of particularly high extraction rates, during which time gravel bars were mined with a dragline and scraped of all available sediment until bedrock was reached (Kelly Guido, Umpqua Sand and Gravel, oral commun., 2008). By the mid-1980s, mined volumes had decreased; in recent decades, most bars owned by the main gravel operators have been mined only 2 to 3 times each (Mike Flewling, Knife River Corporation, oral commun., 2008; Joy Smith, Umpqua Sand and Gravel, oral commun., 2008). Gravel mining regulations have changed substantially since the 1970s, and now near-channel gravel typically is harvested by bar skimming, whereby scrapers or other heavy equipment are used to remove only the surface of the bar, typically to an elevation close to the low-flow water level. No permits for in-stream gravel extraction have been issued since 2004, the last year in which mining occurred upstream of the Tidal reach. In the intervening years, two main operators continue to seek approval for future mining at six sites (figs. 1 and $\underline{9}$ ) on the South Umpqua River:

- Umpqua Sand and Gravel Bar, FPKM 171.4, operated by Umpqua Sand and Gravel

- Shady Bar, FPKM 186.2, operated by Knife River Corporation

- Little Valley Bar, FPKM 189.7, operated by Knife River Corporation

- Weigle Bar, FPKM 211, operated by Knife River Corporation

- Gazley East Bar, FPKM 232, operated by Knife River Corporation

- Days Creek Bar, FPKM 249.9, operated by Knife River Corporation

Extraction volumes for 2001-04 provided by the Umpqua Sand and Gravel and Knife River Corporation show that mining in 2001, 2003, and 2004 removed volumes at individual sites ranging from 610 to 21,500 metric tons (based on volumes provided in bar surveys and a bulk density of 2.1 metric tons/m³ $\mathrm{m}^{3}$. In 2001 and 2003, 9,260 and 610 metric tons of gravel were removed from Umpqua Sand and Gravel Bar, respectively, and in 2004, a combined total of 36,570 metric tons was extracted from Days Creek, Weigle, and Umpqua Sand and Gravel bars. Other sites also may have been mined during this period, but no records were available. 
Table 4. Channel trends and anthropogenic impacts for reaches in the Umpqua River basin, Oregon.

[Abbreviations: FPKM, flood-plain kilometer; $\mathrm{mi}^{2}$, square mile]

\begin{tabular}{|c|c|c|c|c|c|c|}
\hline \multirow{2}{*}{ Attribute } & \multicolumn{6}{|c|}{ Reach } \\
\hline & Tidal & Coast Range & Garden Valley & Roseburg & Days Creek & North Umpqua \\
\hline $\begin{array}{l}\text { Major flow } \\
\text { factors }\end{array}$ & Tidally affected & Minimal regulation & $\begin{array}{l}\text { Minimal } \\
\text { regulation }\end{array}$ & $\begin{array}{l}\text { Galesville Reservoir, } \\
\text { Oct. } 7,1985, \\
\text { regulates } 74.3 \mathrm{mi}^{2} \\
\text { of Cow Creek } \\
\text { basin (5.9 percent } \\
\text { of contributing area } \\
\text { at upper end of } \\
\text { segment) }\end{array}$ & $\begin{array}{l}\text { None } \\
\text { a }\end{array}$ & $\begin{array}{l}\text { Pacific Power dams } \\
\text { constructed } \\
\text { 1952-1955 } \\
\text { regulate (slightly) } \\
\text { drainage from } 430 \\
\text { mi }^{2} \text { (35 percent of } \\
\text { the upper end of } \\
\text { segment) }\end{array}$ \\
\hline $\begin{array}{l}\text { Major } \\
\text { sedimentation } \\
\text { factors }\end{array}$ & $\begin{array}{l}\text { Gradient change } \\
\text { promotes } \\
\text { deposition } \\
\text { of sediment } \\
\text { load; Smith } \\
\text { River sediment } \\
\text { inputs; dredging } \\
\text { (100,000-500,000 } \\
\text { cubic yards per } \\
\text { year) }\end{array}$ & $\begin{array}{l}\text { Sediment input from } \\
\text { tributaries; local } \\
\text { landuse and forest } \\
\text { practices } \\
\end{array}$ & $\begin{array}{l}\text { Local sand and } \\
\text { gravel mining; } \\
\text { forest practices; } \\
\text { Calapooya } \\
\text { Creek sediment } \\
\text { input }\end{array}$ & $\begin{array}{l}\text { Late 19th century } \\
\text { placer mining } \\
\text { in reach and } \\
\text { tributaries; forest } \\
\text { practices; sand } \\
\text { and gravel mining; } \\
\text { tributary sediment } \\
\text { inputs }\end{array}$ & $\begin{array}{l}\text { Forest practices; } \\
\text { sand and gravel } \\
\text { mining; tributary } \\
\text { sediment inputs }\end{array}$ & $\begin{array}{l}\text { Pacific Power dams } \\
\text { trap upstream } \\
\text { sediment; forest } \\
\text { practices }\end{array}$ \\
\hline $\begin{array}{l}\text { Channel } \\
\text { disturbance } \\
\text { factors }\end{array}$ & $\begin{array}{l}\text { Historic navigation } \\
\text { dredging, sand } \\
\text { and gravel mining, } \\
\text { rock removal for } \\
\text { navigation near } \\
\text { Scottsburg; road } \\
\text { corridor }\end{array}$ & $\begin{array}{l}\text { Late 19th century } \\
\text { navigation } \\
\text { improvements; } \\
\text { temporary mill } \\
\text { dam at Kellogg } \\
\text { (removed 1871); } \\
\text { road corridor }\end{array}$ & $\begin{array}{l}\text { Late 19th century } \\
\text { navigation } \\
\text { improvements; } \\
\text { sand and gravel } \\
\text { mining }\end{array}$ & $\begin{array}{l}\text { Local navigation } \\
\text { improvements; } \\
\text { transportation } \\
\text { infrastructure; } \\
\text { log driving; 19th } \\
\text { century mill dams; } \\
\text { sand and gravel } \\
\text { mining; placer } \\
\text { mining }\end{array}$ & $\begin{array}{l}\text { Transportation } \\
\text { infrastructure; log } \\
\text { driving (?); sand } \\
\text { and gravel mining; } \\
\text { placer mining }\end{array}$ & $\begin{array}{l}\text { Navigation } \\
\text { improvement; } \\
\text { log driving; } \\
\text { Winchester Dam } \\
\text { at FPKM } 10.2\end{array}$ \\
\hline $\begin{array}{l}\text { General channel } \\
\text { trends }\end{array}$ & $\begin{array}{l}\text { Some evidence of } \\
\text { local incision } \\
\text { historically near } \\
\text { gravel mining } \\
\text { operations (CH2M } \\
\text { Hill, 1972) }\end{array}$ & $\begin{array}{l}\text { Channel historically } \\
\text { and presently on } \\
\text { bedrock; little or } \\
\text { no evident change } \\
\text { (photos, specific } \\
\text { gage analysis for } \\
\text { Elkton gage) }\end{array}$ & $\begin{array}{l}\text { Channel } \\
\text { historically } \\
\text { and presently } \\
\text { on bedrock. } \\
\text { No obvious } \\
\text { change evident } \\
\text { from inspection } \\
\text { of aerial } \\
\text { and oblique } \\
\text { photographs, } \\
\text { analysis of bar } \\
\text { area }\end{array}$ & $\begin{array}{l}\text { Channel historically } \\
\text { and presently } \\
\text { on bedrock. No } \\
\text { obvious change } \\
\text { evident from } \\
\text { inspection of } \\
\text { aerial and oblique } \\
\text { photographs, } \\
\text { analysis of bar } \\
\text { area, and specfic } \\
\text { gage analysis }\end{array}$ & $\begin{array}{l}\text { Channel locally } \\
\text { on bedrock. No } \\
\text { evident trends, } \\
\text { although limited } \\
\text { data for this reach }\end{array}$ & $\begin{array}{l}\text { Channel historically } \\
\text { and presently } \\
\text { on bedrock. No } \\
\text { evident change } \\
\text { from specific gage } \\
\text { analysis }\end{array}$ \\
\hline
\end{tabular}



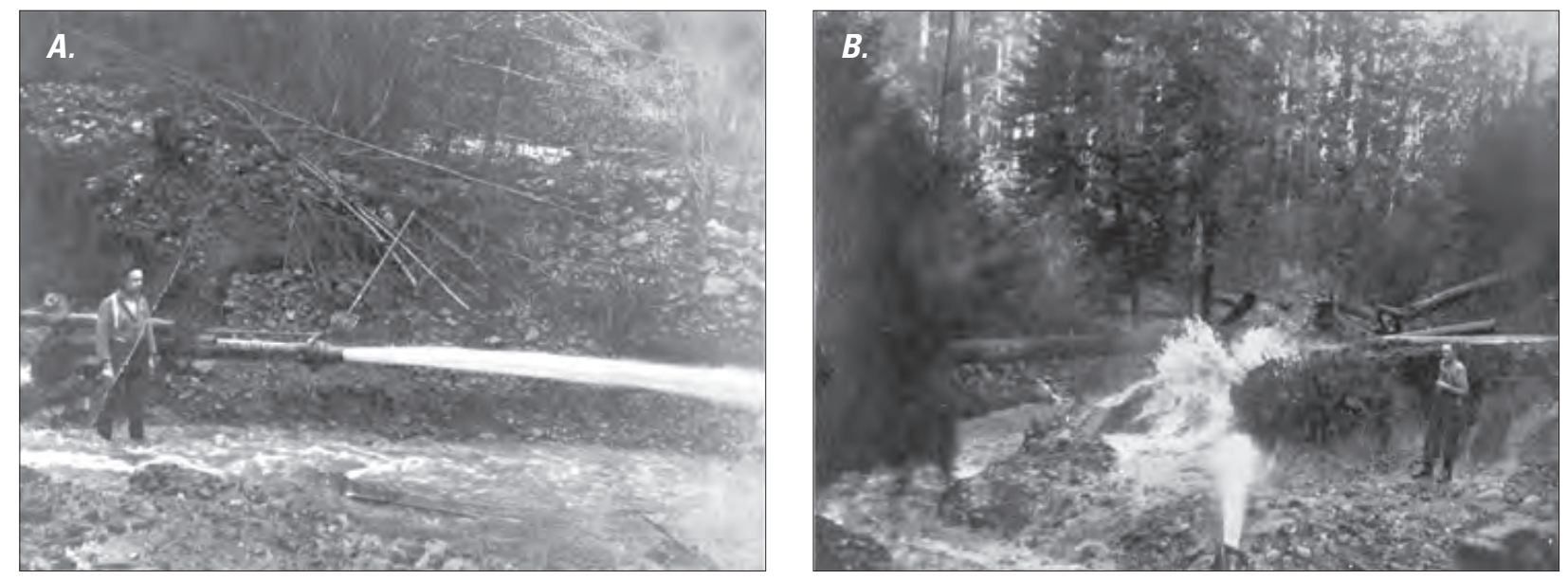

Figure 13. Hydraulic mining in the Olalla District, Lookingglass Creek drainage, Oregon. Photographs courtesy of Douglas County Museum. (Photographs (A) N5155a and $(B)$ N5155b.)

\section{Dams}

Mill dams and other small obstructions served various needs of early settlers, and later, larger dams have provided for hydropower and flood control. Of these early dams near Kellogg (FPKM 105.4; Coast Range reach), Roseburg (FPKM 182; Roseburg reach), and Winchester (NUFPKM 10.2; North Umpqua reach), only the Winchester Dam, a 3-m-high concrete structure on the lower North Umpqua River, remains. Anecdotal accounts indicate that some gravel passes over Winchester Dam, although most bed-material sediment is likely trapped in its shallow upstream reservoir, which has aggraded approximately $2 \mathrm{~m}$ since dam construction in 1904 (Timothy Brady, City of Roseburg Water Plant Superintendent, oral commun., November 15, 2010).

Pacific Power's North Umpqua Hydroelectric Project was constructed during 1952-55 and now traps bedload from the upstream 32 percent of the North Umpqua River basin. However, a 2002 amendment to the 2001 Federal Energy Regulatory Commission (FERC) re-licensing settlement for PacifiCorps' hydroelectric project in the North Umpqua Basin calls for a gravel augmentation plan to increase the amount of spawning habitat downstream of Soda Springs Dam (fig. 1, PacifiCorp, 2002). The augmentation plan included a onetime experimental pulse of 2,300 $\mathrm{m}^{3}$ of spawning size gravel, equivalent to the long-term average annual bedload input to this reach, or approximately 3,680 metric tons (based on a bulk density of 1.6 metric tons $/ \mathrm{m}^{3}$ as provided by Stillwater Sciences, written commun., 2010), which was added to the river in August of 2004 (Stillwater Science, 2006). Additionally, $56 \mathrm{~m}^{3}$ (approximately 90 metric tons) will be distributed seven times during the course of the new FERC license (PacifiCorp, 2002). Sediment studies conducted as part of relicensing these facilities and to monitor the gravel augmentation are summarized later in the section "Previous Water and Sediment Studies in the Umpqua River Basin." Galesville Reservoir on Cow Creek began filling in 1985, and since then has trapped all bed material from the upper $192.4 \mathrm{~km}^{2}$ of Cow Creek, encompassing 5.9 percent of the South Umpqua River basin at the Cow Creek confluence.

\section{Forest Management and Fire}

Because they potentially influence large portions of the basin, watershed-scale disturbances, including forest fires, development and logging, and related activities can affect channel morphology and bed-material conditions throughout the Umpqua River basin. Timber harvest and associated road building can increase peak flows (Wemple and others, 1996; Jones and Grant, 1996, 2001; Bowling and others, 2000) and the frequency of landslides (Kelsey and others, 1995), resulting in sedimentation along lower reaches of affected basins (Madej, 1995). Douglas County, whose boundaries closely follow that of the Umpqua River basin, was second in the nation in timber harvest from Federal lands between 1949 and 1970 (Beckham, 1986, p. 174).

Peak timber production was during the 1950s-1960s, when annual timber harvest from National Forest Lands in Douglas County ranged from 149.6 to 637.6 million board feet (Beckham, 1986, p. 174). Log production from public lands decreased substantially after 1988 when management emphasis shifted from timber production to habitat protection. For comparison, log production in 1988 was 397 million board feet, but annual average harvest 1991-2000 was 29 million board feet, which diminished to 6.7 million board feet during 2001-03 (as calculated from data provided by U.S. Forest Service, 2006). Although detailed records describing historical logging practices, road building, and associated landscape 
changes are lacking for the Umpqua River basin, it is possible that intensive timber harvest peaked in the 1950s-1960s, but remained elevated through the 1980s, likely affecting bed-material influx to the Umpqua River and its major tributaries.

Linking historical patterns of forest fire with changes to channel character is difficult due to sparse records connecting fire extent and severity to subsequent changes in channel condition. Historically, Native Americans used annual, late-summer fires to clear brush and ensure open areas for hunting and berry gathering along valley bottoms (Beckham, 1986). By the early 1900s, however, Federal fire-suppression programs became more aggressive (Beckham, 1986; Geyer, 2003a-d). In recent decades, fires have burned increasingly larger areas of the basin, including fires in 1987 (31 km² burned area), 1996 (73 km²), and $2002\left(341.8 \mathrm{~km}^{2}\right)$ (as determined from U.S. Forest Service [2010] mapping data). Most of the fires in 2002, including the Boulder Fire $\left(193 \mathrm{~km}^{2}\right)$, were in the South Umpqua River basin, where 6 percent of the total drainage basin area was burned (as determined by the U.S. Forest Service [2010]). Possible long-term effects of these fires include increased runoff and erosion associated with canopy removal (U.S. Forest Service, 2003).

\section{Navigation Improvements and Commercial Dredging}

Historical navigation improvements were focused in the Tidal reach, which has been the only section of river with extensive commercial boat traffic, but upstream reaches also had many rapids modified in the early 1870 s in an attempt to promote navigation from the Pacific Ocean to Roseburg (Markers, 2000). Likewise, some bedrock rapids were modified in the late 19th century on the South Umpqua and North Umpqua Rivers to facilitate log drives (Beckham, 1986).

By 1900, the emphasis on improving navigation on the Umpqua River shifted to the river's mouth, and between the 1920s and 1940s, the USACE, together with local entities, constructed major jetties to ensure a stable entrance to the lower river channel (Beckham, 1986). Beginning in 1927, the Corps of Engineers also began deepening the channel between the river's mouth and Reedsport, and constructed a boat turning basin in Winchester Bay in 1945 (Beckham, 1986, p. 153). Navigational dredging by the Corps of Engineers has continued, with annual removal volumes from 1991 to 2008 averaging 157,070 $\mathrm{m}^{3}$ (fig. 14; Judy Linton, U.S. Army Corps of Engineers, written commun., 2008).
Commercial dredging of the Umpqua River estuary for sand and gravel aggregate began in 1918 and has been focused primarily in the area near Brandy Bar, between FPKM 25.9 and 30.6, where Umpqua River Navigation Company and its successor Knife River Corporation operated between 1949 and 2002 (Lidstone and Associates, written commun., 2008). The amount of bed-material sediment removed by commercial dredging during this period ranged from 22,070 to $339,250 \mathrm{~m}^{3} / \mathrm{yr}$, averaging $136,380 \mathrm{~m}^{3} / \mathrm{yr}$ (fig. 14 ; as determined from records provided by Lidstone and Associates, written commun., 2008; CH2M Hill, 1971).

\section{Previous Water and Sediment Studies in the Umpqua River Basin}

Previous reports from hydrology and sediment transport studies for the Umpqua River basin were reviewed for this study. Although many studies are peripherally related (such as turbidity and other water-quality studies), two previous studies are directly relevant to gravel transport and channel morphology in the study area: (1) the basinwide analysis of sediment transport by Curtiss (1975) and (2) the sediment transport analyses by Stillwater Sciences (2000) in support of the FERC relicensing of the Pacific Power hydroelectric facilities on the North Umpqua River.

The Curtiss (1975) report expands on an earlier USGS report by Onions (1969) by providing estimates of annual suspended-sediment discharge for 11 sites in the Umpqua River basin based on as many as 18 years of suspended-sediment measurements between 1956 and 1973. Although there were no measurements of bedload in this study, Curtiss (1975) calculated total sediment loads (bedload plus suspended load) on the basis of measurements at Flynn Creek (a Coast Range stream in the Alsea River basin), where bedload constituted 3 percent of the mean annual suspended-sediment yield. This ratio was applied for the sites in the Umpqua River basin, except for Cow Creek, where field observations implied that bedload composed 5 percent of the total load. Although no known bedload measurements for the Umpqua River system substantiate these values, bedload transport rates typically scale with suspended load, and the analysis by Curtiss (1975) probably provides a reasonable guide to the relative contributions of bed material to the Umpqua River system. For the calculated mean annual total sediment discharge of $1.54 \times 10^{6}$ metric tons/yr of the South Umpqua River at Brockway, the Curtiss (1975) analysis indicates that $0.28 \times 10^{6}$ metric tons/yr enters through Lookingglass Creek, $0.34 \times 10^{6}$ metric tons/yr joins at Cow Creek, and $0.28 \times 10^{6}$ metric tons/yr comes from the upper basin upstream of the Tiller gaging station. 


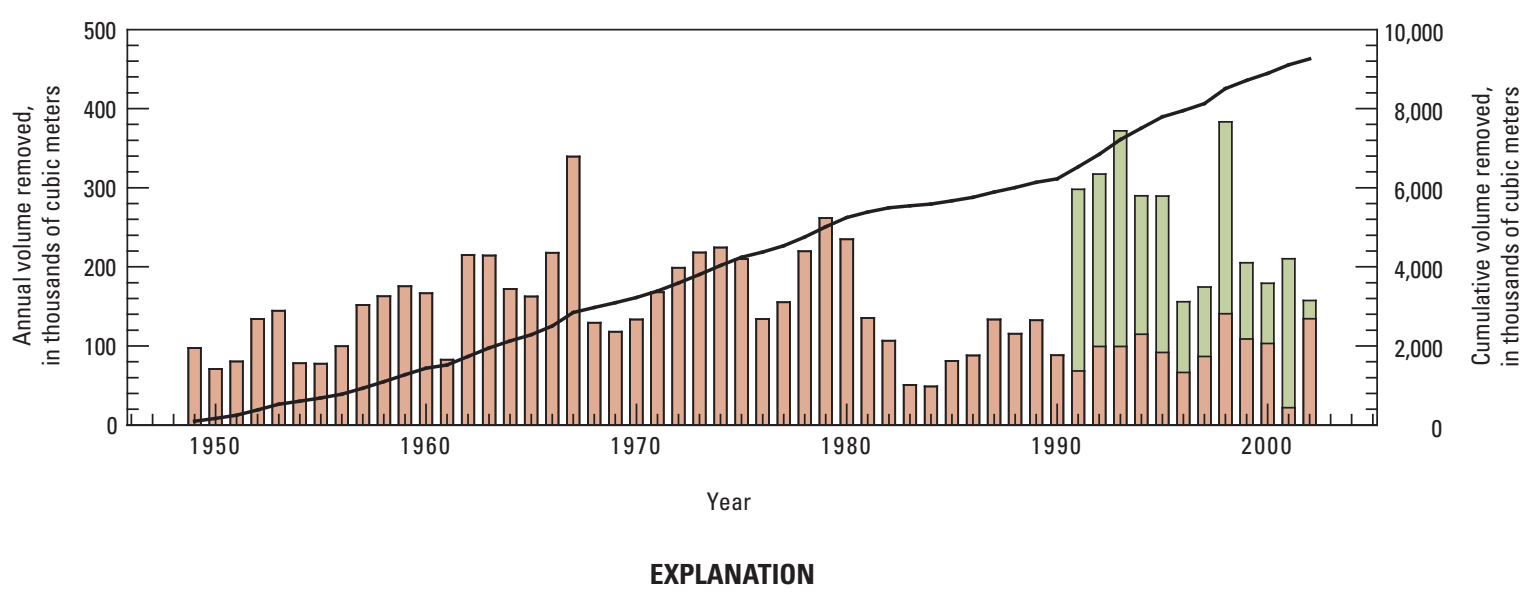

URN/Knife River 1949-2002 (average $=136,000$ cubic meters per year) USACE Navigational Dredging 1991-2002 (average $=158,000$ cubic meters per year) Cumulative Total

Figure 14. Annual sediment volume removed between 1949 and 2002 by commercial and navigational dredging in the Umpqua River estuary, Oregon. Commercial dredging focused mainly on the lower Umpqua River below FPKM 40, whereas navigational volumes provided by the U.S. Army Corps of Engineers (USACE) are mainly for the Umpqua River entrance (FPKM 0-3) near Reedsport. Descriptions include Umpqua River Navigation Company (URN).

These values suggest that more than 80 percent of the sediment entering the South Umpqua River is derived from tributaries downstream of Tiller. At the Elkton streamflow-gaging station on the main stem Umpqua River, where $3.18 \times 10^{6}$ metric tons/yr of sediment passes each year, 23 percent is from the North Umpqua River at Winchester $\left(0.72 \times 10^{6}\right.$ metric tons/yr), 49 percent from the South Umpqua River at Brockway $\left(1.54 \times 10^{6}\right.$ metric tons/yr), 5 percent from the Calapooya Creek $\left(0.17 \times 10^{6}\right.$ metric tons/ yr), with the balance likely from the lower South Umpqua River and unmeasured tributaries entering the main stem Umpqua River between the confluence of the North Umpqua and South Umpqua Rivers and the Elkton streamflow-gaging station. These results indicate that the South Umpqua River supplies a greater amount of sediment to the Umpqua River than is contributed by the North Umpqua River.

In terms of bed-material transport, if the 3 and 5 percent ratios are correct, the Curtiss (1975) measurements indicate an annual bedload transport rate of 8,400 metric tons at Tiller, near the upstream end of the Days Creek reach at FPKM 273; 46,000 metric tons at the Brockway streamflow measurement site on the South Umpqua River within the Roseburg reach near FPKM 195.3; and 160,000 metric tons at the Elkton measurement site on the main stem Umpqua River in the Coast Range reach at FPKM 72.1. Considered similarly, Cow Creek, the North Umpqua River, Lookingglass Creek, and Calapooya Creek contributed 17,000, 22,000, 8,400, and 5,100 metric tons/yr, respectively, to the South and main stem Umpqua Rivers. Considering the relative propensity of the Klamath Mountains terrain to produce gravel compared to the other geologic provinces, as well as the dams on the North Umpqua River (which would reduce bed-material fluxes substantially in comparison with suspended loads), the Curtiss (1975) estimates probably exceed actual values for the North Umpqua River and Umpqua River at Elkton sites.

Stillwater Sciences (2000) prepared sediment budgets for the North Umpqua River to assess the role of Pacific Power's North Umpqua River hydroelectric project on North Umpqua River sediment conditions. Their analysis incorporated a reanalysis of the suspended load data summarized by Curtiss (1975), analysis of reservoir sedimentation data, estimates of geomorphic process rates, and landslide inventory information. They concluded that the dams on the North Umpqua River trap all bedload from the upper 32 percent of the North Umpqua River basin but that the effect of this bedmaterial sediment reduction on downstream reaches is more than compensated by enhanced sediment production from 20th century land-use practices - primarily forest practices - and the effects of the 1964 flood. Specifically, Stillwater Sciences (2000) postulated that downstream of Steamboat Creek (a tributary entering the North Umpqua River approximately $30 \mathrm{~km}$ upstream of the study area), the effects of land use 
doubled the average annual bedload flux to 16,330 metric tons/ yr, from a "reference condition" (pre-1950, minimal land-use effects) value of less than 8,160 metric tons/yr, despite total bed-material blockage since 1952 at Soda Springs Dam (about $60 \mathrm{~km}$ upstream of the study area). Although these conclusions for the North Umpqua River remain unverified, enhanced bed-material contributions to the Umpqua River system from increased sediment yield in managed lands may be an important basinwide factor.

Stillwater Sciences also monitored the August 2004 experimental gravel augmentation, which entailed a release of 3,680 metric tons of spawning size gravel at two sites near Soda Springs Dam (Stillwater Sciences, 2006). Reconnaissance-level monitoring following the augmentation determined that (1) the experiment demonstrated where natural deposition would occur within this confined section of river and (2) a 2-year recurrence-interval flow in December 2004 was sufficient to mobilize all of the augmentation gravel; however, a 5-year recurrence-interval flood in December 2005 redistributed the spawning gravels along the channel margins. Overall, the August 2004 gravel augmentation experiment increased the total area of suitable spawning habitat between Soda Springs Dam and Boulder Creek (Stillwater Sciences, 2006).

\section{Valley Bottom Mapping and Analysis of Historical Channel Change}

A primary goal of this study was to characterize channel conditions throughout the study area and evaluate spatial and temporal patterns in gravel storage, as this forms a basis for determining historical variation in bed-material flux. Because the fluvial reaches of the Umpqua River study area above the head of tide at FPKM 40 share similar overall morphology and management issues, these reaches were assessed separately from the Tidal reach, although a similar overall approach was used for both areas.

For the fluvial reaches, analysis of multiple sets of aerial photographs dating to 1939 were used to evaluate planimetric changes in channel morphology and gravel storage, supplemented by historical surveys and photographs from the mid-19th century and early 20th century. Historical variation in bed elevations were assessed using the record of channel geometry at four USGS streamflow-gaging stations and repeat longitudinal profile surveys from 1914 to 2009. Annual topographic surveys from mined sites on the South Umpqua River from between 2001 and 2009 enabled assessment of deposition rates and bar evolution following gravel extraction and various magnitude flood events. For the Tidal reach, repeat channel mapping from aerial photographs and General Land Office (GLO) surveys was used, but with a slightly different mapping protocol. Additionally, bathymetric changes and channel deepening in the Tidal reach were assessed through comparison of historical navigational surveys from 1886 to 1971 and by reviewing previous reports (Lidstone and Associates, written commun., 2008; CH2M Hill, 1971). We first describe the analysis of planimetric and vertical changes for the fluvial reaches, and then discuss the repeat mapping and bathymetric analyses for the Tidal reach.

\section{Historical Changes in Channel Planform and Vegetation Density above the Head of Tide}

Historical changes to channel planform and vegetation density along the fluvial reaches were evaluated primarily through repeat mapping of the active channel from aerial photographs from 1939 to 2009. GLO surveys dating to the 1850s and reoccupation of land-based photographs dating to the early 1900s extend our characterization of channel conditions into the 19th century and supplement findings from the detailed mapping. Because a major objective of the overall study is to characterize patterns of gravel storage and rates of bed-material flux, we focused our mapping activities, as well as analysis of historical GLO surveys and oblique photographs, on changes to channel character and abundance of gravel bars. In most instances, current information on channel planform and vegetation was based on the $0.5 \mathrm{~m}$ orthoimagery for 2005 developed from summer 2005 aerial photographs as part of the U.S. Department of Agriculture National Agriculture Imagery Program (NAIP).

\section{Acquisition and Rectification of Historical Aerial Photographs}

Aerial photographs from different periods provide a basis for systematic mapping of channel features and their changes. Historical aerial photographs from 1939 and 1967 were available only as scanned images, and these were georeferenced, rectified, and mosaicked to form a seamless layer for digital mapping. Recent aerial photographs from 1995, 2000, 2005, and 2009 were available as digital orthophotographs and did not require additional processing prior to mapping (table 5). All photographs were acquired during late spring to summer, when discharge was relatively low, although the discharge varies between periods (table 6).

A complete description of the process by which the aerial photographs from 1939 and 1967 were scanned, georeferenced, rectified, and mosaicked is provided in the 
Table 5. Aerial photographs and orthophotographs used in the sediment transport study, Umpqua River basin, Oregon.

[Abbreviations: RMSE, root mean square error (in meters) is provided for photographs rectified in this study; FPKM, flood-plain kilometer; NUFPKM, North Umpqua River flood-plain kilometer; NAIP, National Agriculture Imagery Program; USACE, U.S. Army Corps of Engineers; USDA, U.S. Department of Agriculture; USGS, U.S. Geological Survey; m, meter; BW, black and white]

\begin{tabular}{lllllc}
\hline Year & \multicolumn{1}{c}{ Original format } & \multicolumn{1}{c}{ Coverage } & $\begin{array}{c}\text { Photo scale or } \\
\text { orthophotograph } \\
\text { resolution }\end{array}$ & $\begin{array}{c}\text { Original } \\
\text { source }\end{array}$ & $\begin{array}{c}\text { Rectification source } \\
\text { and RMSE }\end{array}$ \\
\hline 1939 & Aerial photograph (BW) & Full coverage & $1: 10,200$ & USACE & This study (4.48 m) \\
1967 & Aerial photograph (BW) & FPKM 8-275; NUFPKM 0-44 & $1: 20,000$ & USDA & This study (2.22 m) \\
$1994-1995$ & Orthophotograph (BW) & Full coverage & 1 pixel = $1 \mathrm{~m}$ & USGS & USGS \\
2000 & Orthophotograph (BW) & Full coverage & 1 pixel = $1 \mathrm{~m}$ & USGS & USGS \\
2005 & Orthophotograph (color) & Full coverage & 1 pixel $=0.5 \mathrm{~m}$ & NAIP & NAIP \\
2009 & Orthophotograph (color) & Full coverage & 1 pixel $=1 \mathrm{~m}$ & NAIP & NAIP \\
\hline
\end{tabular}

metadata for these layers (available at http://www.geodata. gov), and summarized here. Aerial photographs from 1939 were obtained from the U.S. Army Corps of Engineers and scanned by USGS staff. Scanned copies of the U.S. Department of Agriculture 1967 photographs were obtained from the University of Oregon Map and Aerial Photography Library (table 5). The photographs were spatially registered in ArcGIS 9.3, using NAIP 0.5-m resolution digital orthophotographs acquired in 2005 as a base layer to which ground control points were matched. Ground control points generally consisted of building corners or bedrock outcrops located within or near the channel and flood plain.

Most georeferencing of photographs was done using a second order polynomial transformation; photographs with fewer than six control points were rectified using a first order polynomial transformation. Each of the georeferenced photographs was rectified by resampling to a cell size of $0.5 \mathrm{~m}$ using bilinear interpolation within the Georeferencing Toolbar in ArcGIS 9.3 and then clipped to include areas near the channel where the control points had been concentrated. Seamless mosaics, composed of 184 aerial photographs from 1939 and 79 photographs from 1967 were then created from the clipped, rectified images from each period. Lastly, a polygon layer was created to catalog attributes for each of the photographs underlaying the mosaics, including flight date, number of ground control points to spatially register the original photograph, root mean square error associated with the georeferencing, and approximate discharge at the time of the photograph.

\section{Mapping Channel Features, Vegetation Density, and Geomorphic Flood Plain}

Aerial photographs from 1939, 1967, and 2005 were used to map geomorphic features within the active channel of each study reach. In the Days Creek, Roseburg, and Garden Valley reaches, geomorphic mapping also was conducted for three additional periods during 1995, 2000, and 2009 to allow further analysis of recent channel change along these more gravel-rich reaches. The resultant digital channel maps form a basis for evaluating systematic changes to channel and bar planform and support the analysis of depositional and erosional volumes. Vegetation density also was mapped within the active channel in order to evaluate changes that may be attributable to channel processes.

Mapping of geomorphic features was primarily confined to the active channel, defined as the area typically inundated during annual high flows as determined by the presence of water and flow-modified surfaces (Church, 1988). Features within the active channel were divided into five broad mapping units: (1) the primary, low-flow channel, (2) tributary channels, (3) bars, (4) secondary channel features, and (5) bedrock outcrops. For each period, all features larger than about $300 \mathrm{~m}^{2}$ were digitized at a scale of 1:3,000. To ensure consistency between mapped reaches and periods, an iterative review protocol was developed so that all line work was reviewed and finalized, and then verified by multiple members of the project team. 


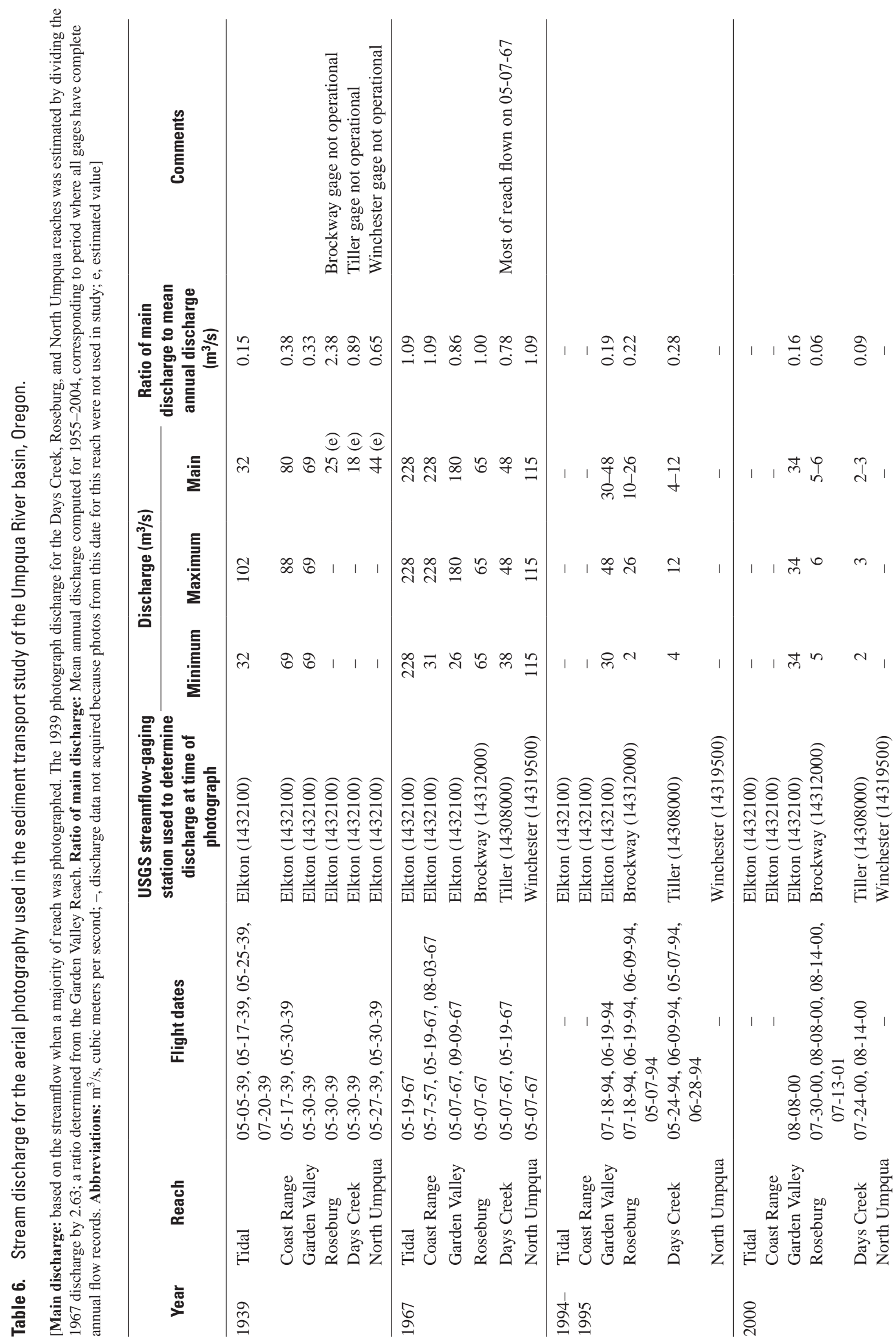




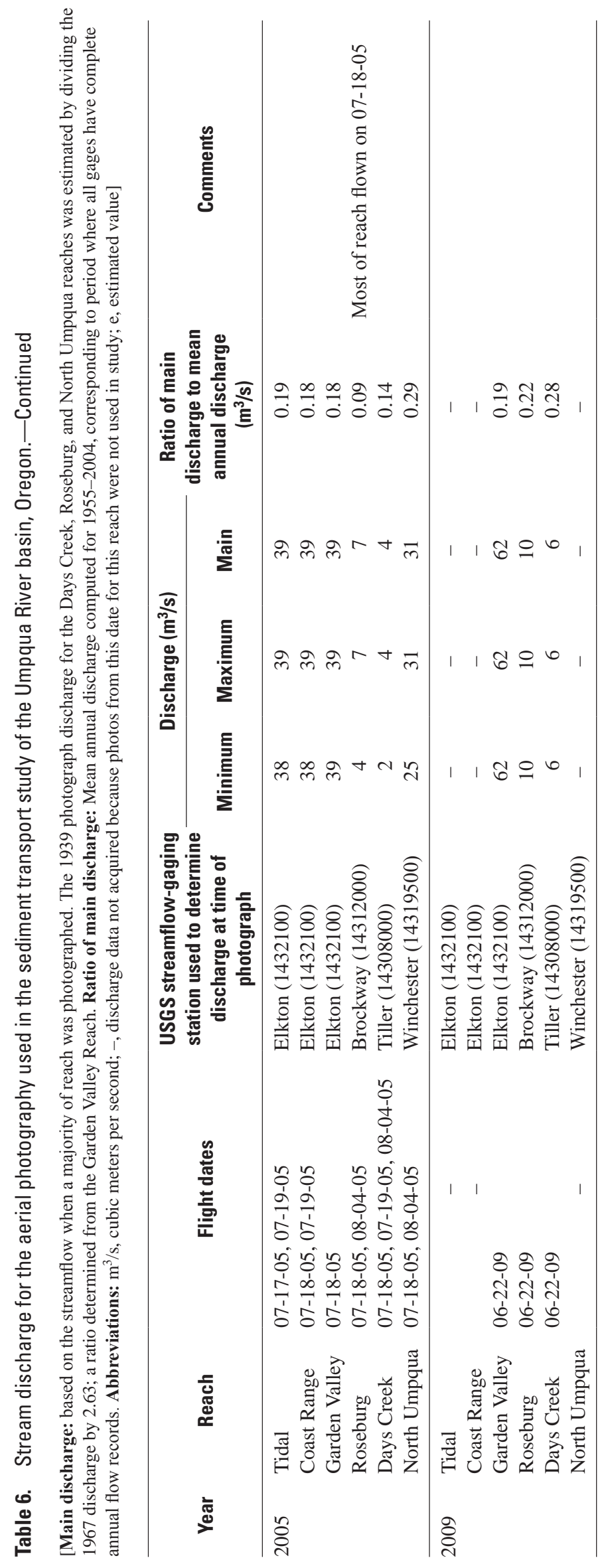


The primary channel of the Umpqua River, as well as the North and South Umpqua Rivers, was mapped by digitizing the wetted perimeter of the channel as depicted in the aerial photographs. For larger tributaries whose mouths were wider than $20 \mathrm{~m}$, the wetted perimeter of the tributary was mapped for a distance of $500 \mathrm{~m}$ upstream of its confluence with the Umpqua River. Secondary channel features generally were associated with alluvial features, such as gravel bars and included side channels, backwater sloughs, and disconnected water bodies adjacent to alluvial features. In many locations, water ponded in potholes and fractures within bedrock outcrops, forming shallow, but sometimes large (greater than $300 \mathrm{~m}^{2}$ in area) water bodies that were disconnected from the main channel (fig. 15). In most cases, they were not mapped separately from the surrounding bedrock outcrop.

For this study, gravel bars were defined as features greater than $300 \mathrm{~m}^{2}$ in area containing exposed bed-material sediment. This definition encompassed a range of features from thin patches of gravel overlying bedrock to large point bars and lateral bars (fig. 15). Gravel bars were divided into two categories: attached bars (sharing a margin with the flood plain) and medial bars (surrounded by water) following the classification scheme of Church and Jones (1982). No specific identification of sediment size was made during the aerial photograph mapping, although field measurements and observations indicate that in the fluvial reaches, most bars were composed of gravel, but for the Tidal reach, mapped bars were composed primarily of sand and mud. Mapped bars locally included small areas (less than $300 \mathrm{~m}^{2}$ ) of open water and bedrock outcrops that were not differentiated from the main bar outline.

Exposed bedrock is common within the Umpqua River active channel, forming islands and channel-adjacent outcrops, and most of the rapids (figs. 2 and 16). Distinguishing bedrock from sediment in the aerial photographs was difficult in some locations, but the task was aided by bedding and jointing apparent in some outcrops and by their jagged, irregular outline near the water's edge. When the photograph resolution was insufficient to make a determination of bedrock versus sediment, photographs from other periods were used to assist in interpretation. Many of the bedrock outcrops are partly covered by small (less than $300 \mathrm{~m}^{2}$ ) patches of sediment or water.
Vegetation density was mapped for all alluvial surfaces within the active channel and all bar features were divided according to three broad categories. Surfaces with less than 10 percent vegetative cover were considered "Bare" and typically occurred on lower elevation bar surfaces. Areas with "Moderate" vegetation density had 10-50 percent vegetative cover, whereas surfaces with "Dense" vegetation had greater than 50 percent cover and typically were mapped on high elevation surfaces near the flood plain. We made no distinction or identification of species as part of this mapping.

The geomorphic flood plain was mapped to provide a static reference frame from which to consider temporal variation to the active channel. For this study, the geomorphic flood plain was defined as the active channel (as described above) and the flanking geomorphic surfaces formed of recent river deposits. These were mapped at a scale of $1: 10,000$ on the basis of topography and the extent of flood-plain soils as depicted in the Soil Survey Geographic Database (Natural Resources Conservation Service, no date). Areas within the geomorphic flood plain are considered to be formed during the recent (Holocene epoch) climatic regime and include most Quaternary deposits mapped in Wells and others (2001) and $\mathrm{Ma}$ and others (2009). The flood-plain kilometer reference system used to denote locations in this study was developed by digitizing a centerline through the geomorphic flood plain.

To evaluate spatial and temporal trends in channel morphology, measurements from the repeat channel mapping were used to calculate several metrics of channel change. Temporal variation in channel length was determined by digitizing centerlines through the main, wetted channel for each period. These lengths allowed computation of sinuosity (calculated by dividing reach-segregated centerline length by the corresponding flood-plain length for that reach). Spatial and temporal patterns in wetted channel width were determined for each period by measuring the main wetted channel orthogonal to the channel centerline at $0.5-\mathrm{km}$ intervals. Reach-aggregated patterns of sediment storage were evaluated by normalizing the cumulative gravel bar areas for each reach, and for each period, by the corresponding 2005 centerline length for that reach. This measure, which we term "specific bar area," represents the area of gravel bar per unit length of channel and enables comparisons between reaches and periods. Longitudinal trends in gravel storage were assessed by overlaying the gravel bar polygons for each period with the flood-plain transect system and then tracking spatially discrete changes in bar area over time. 


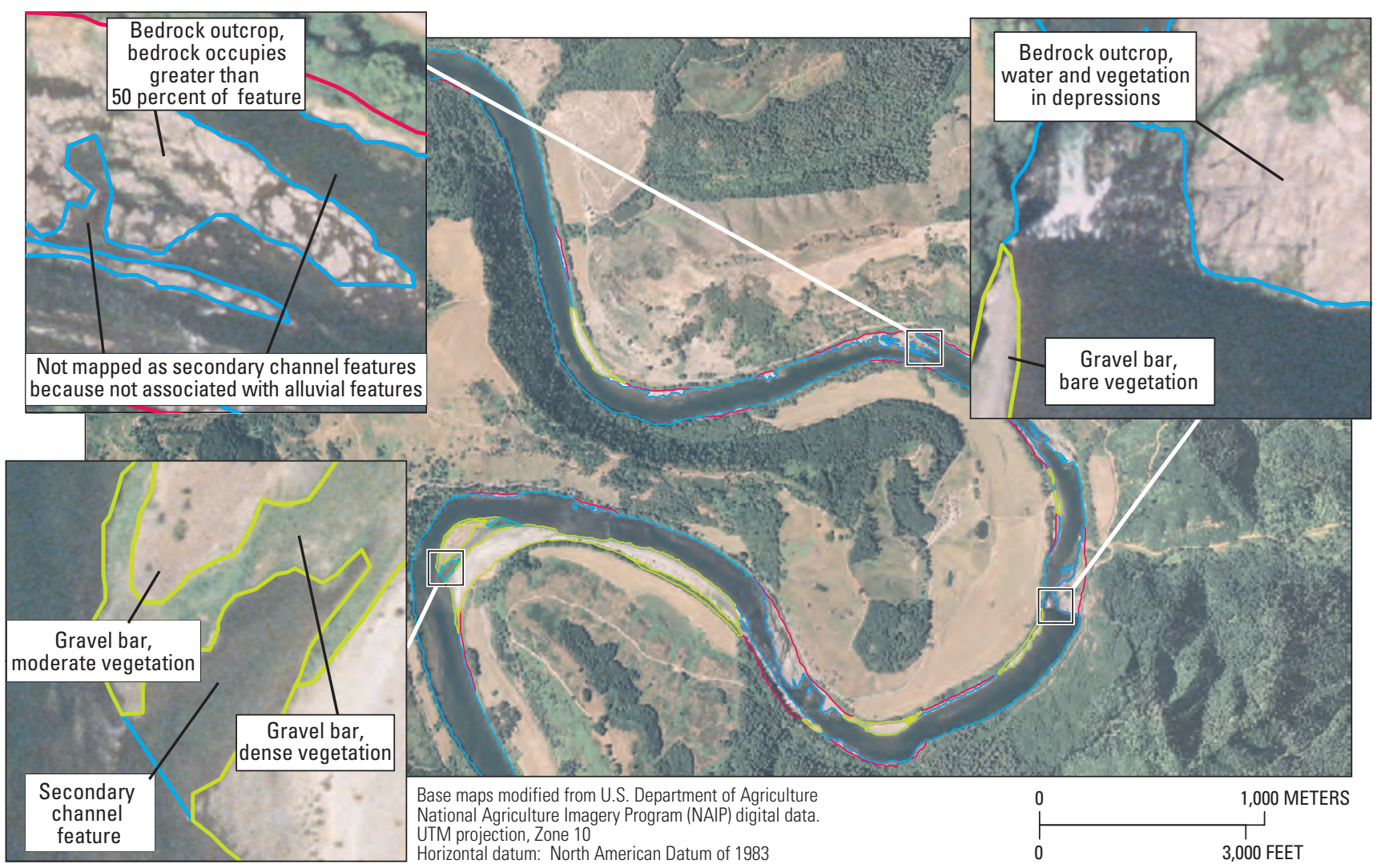

Figure 15. Examples of mapping units used when creating historical channel maps of the Umpqua River basin, Oregon.

\section{Uncertainties and Limitations to Planimetric Mapping}

Uncertainty and error in this interpretative mapping falls into two main categories: (1) errors related to photograph registration and rectification or (2) errors related to mapping of land-surface features, which are mostly due to the challenges imposed by varying light conditions, river discharge, and photograph sharpness and contrast (Gurnell, 1997; Mount and Louis, 2005; Hughes and others, 2006, Walter and Tullos, 2009). In this study, imprecise registration and rectification of historical aerial photographs from 1939 and 1967 stem from the few high-quality control points that are common to both older photograph sets as well as orthophotographs from 2005. The total root mean square error (RMSE) values of the rectified photographs indicate that horizontal position uncertainties range from 0.5 to $13.2 \mathrm{~m}$, but average $4.5 \mathrm{~m}$ for the 1939 photographs and $2.2 \mathrm{~m}$ for the 1967 photographs. Because the control points were concentrated near the channel, the error associated with mapped features along channel corridor should be lower than the total RMSE values for the entire photograph. 

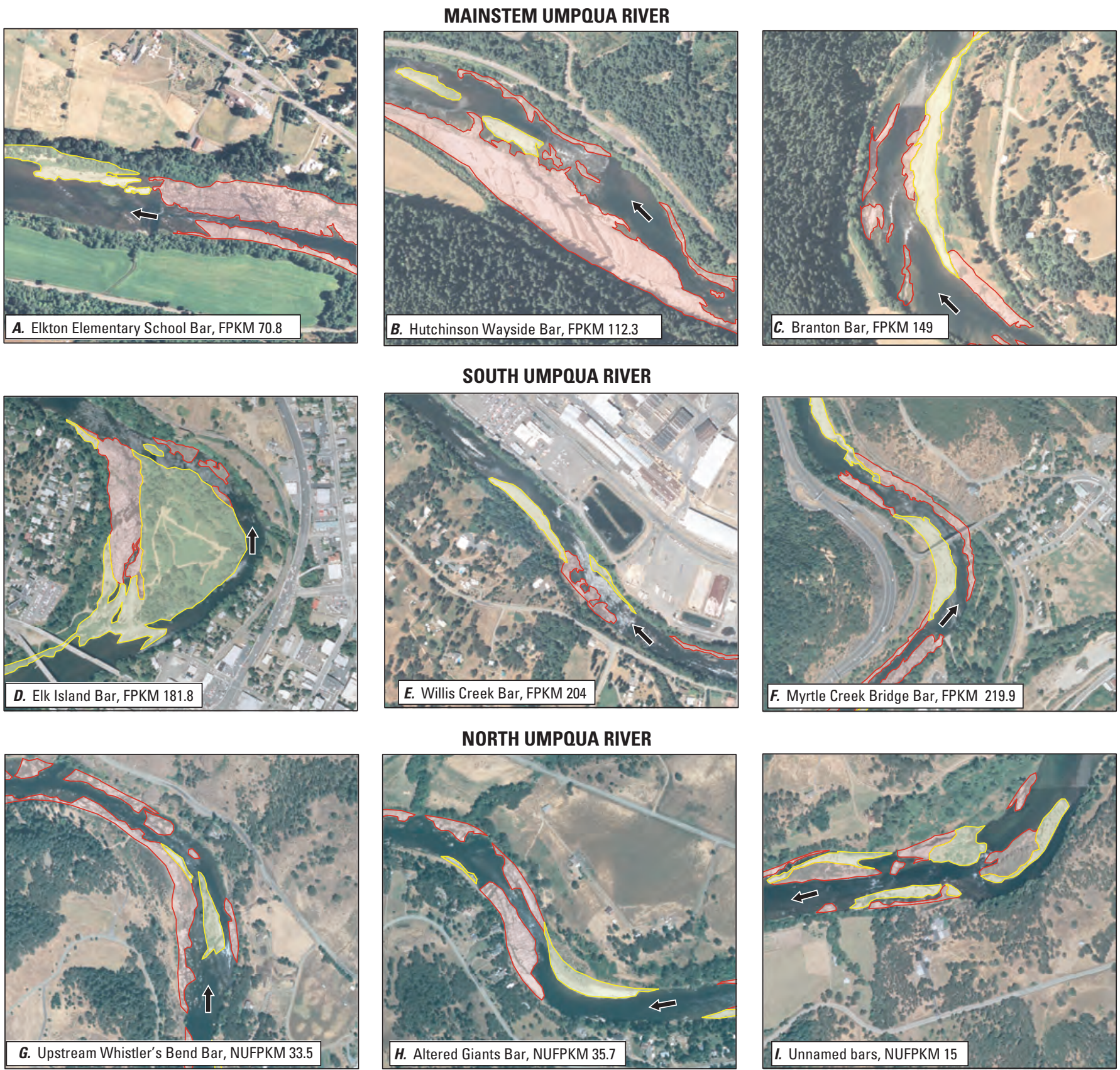

Base maps modified from U.S. Department of Agriculture National Agriculture Imagery Program (NAIP) digital data. UTM projection, Zone $10 \mathrm{~N}$

EXPLANATION

Horizontal datum: North American Datum of 1983
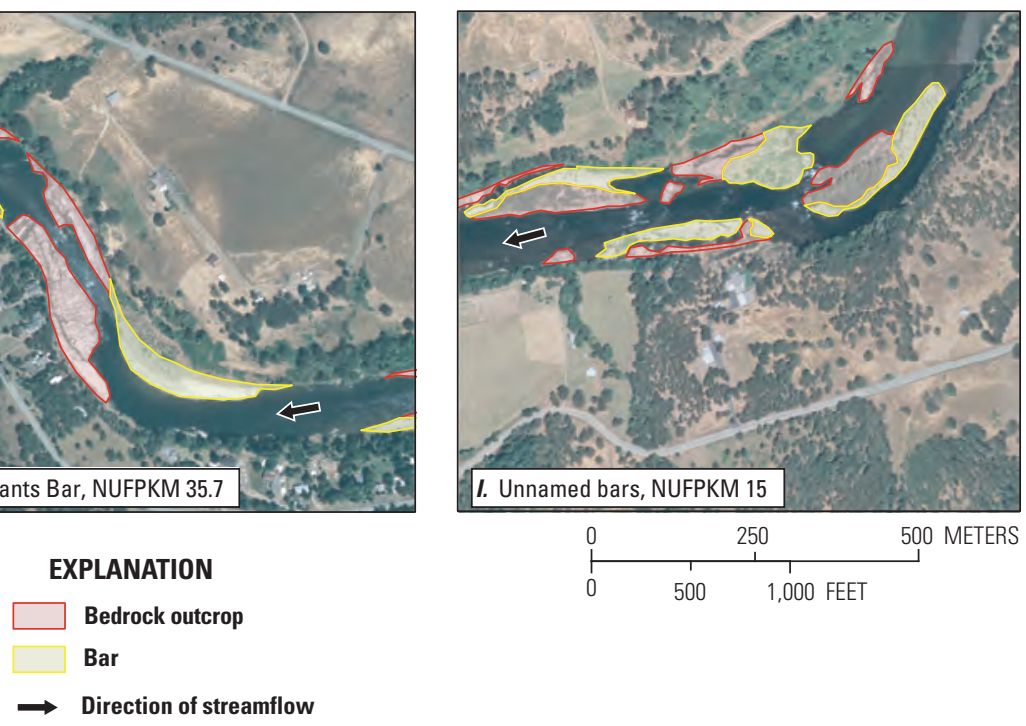

Figure 16. Examples of gravel bars in close proximity to bedrock outcrops in the Umpqua River, Oregon. 
Mapping of channel features was affected by the quality and resolution of the available photographs. Although some photographs had greater amounts of glare, shadows, or other characteristics that locally obscured channel features, the photographs generally were of adequate quality for precise mapping. The main mapping challenge was to discern patches of alluvium from adjacent bedrock, which was particularly difficult for some of the black and white aerial photographs from 1939, 1967, and 1995. Error was also introduced by imprecise line placement, which may conservatively result in horizontal inaccuracies of up to $9 \mathrm{~m}$. However, to minimize errors and increase the overall precision of the interpretive mapping, all line work was verified regularly and repeatedly by other members of the project team.

Another consideration in comparing channel maps from different periods is differences in discharge between sets of aerial photographs. Although all photography was acquired during low-flow periods (table 6), small changes in discharge influence the delineation of channel, bar, and bedrock areas, particularly where the channel is wide and relatively shallow. In general, we expect that mapping from aerial photographs with relatively low discharges (such as those from 2000, when discharge ranged from 6 to 16 percent of the mean annual discharge) will produce results biased toward lower water area and greater bar and bedrock areas. By contrast, photographs made during high discharges, such as 1967 when discharge was about similar to the mean annual discharge, will be biased towards greater water area and smaller bar area. The least amount of discharge variability is among the orthophotographs from 1995, 2000, 2005, and 2009 (table 6) when streamflows for most photographs were less than 20 percent of the mean annual discharge, so comparing channel maps from these time periods should minimize uncertainty due to differences in discharge.

To partially account for the effects of the different discharges associated with the aerial photographs and the effects of these differences on mapped bar area, we normalized the mapped bar areas for some of the reaches to a common minimum discharge according to:

$$
\mathrm{A}_{\mathrm{Qi}}=\mathrm{A}_{\mathrm{m}}+\mathrm{b}\left(\mathrm{Q}_{\mathrm{m}}-\mathrm{Q}_{\mathrm{i}}\right),
$$

where

$\mathrm{A}_{\mathrm{Qi}}$ is the bar area for year $\mathrm{m}$ normalized to the index discharge;

$\mathrm{Q}_{\mathrm{i}}$ is defined as the lowest discharge for which the reach has bar-area measurements (for the cases here, the 2000 photographs);

$A_{m}$ is the measured bar area for a particular set of photographs from year $m$ for which the discharge was $\mathrm{Q}_{\mathrm{m}}$; and

b is the regression coefficient for the reachspecific relation between measured bar area and discharge for 1995, 2000, 2005, and 2009 (fig. 17).
These relations were developed for the Days Creek, Roseburg, and Garden Valley reaches and had correlation coefficients $(r)$ ranging from 0.55 for the Garden Valley reach to 0.95 for the Days Creek reach (fig. 17). Reach-specific linear regressions were not developed for the Coast Range and North Umpqua reaches because of too few measurements, so the Garden Valley reach regression was applied to the Coast Range reach, whereas the bar areas on the North Umpqua Reach were not normalized. The discharges for 1939 and 1967 photograph sets ("photograph discharges") are higher than discharges for the 1995-2009 photographs from which the regressions are derived, so measurements from 1939 and 1967 cannot be reliably adjusted. Mapped bar areas for those years, however, would certainly have been larger if the photograph discharges were similar to those of 1995-2009. The normalized values for the Coast Range and Garden Valley reaches are tentative since they are based on the nonsignificant Garden Valley regression (although the regression coefficient is small, so the normalized values are not too different from the measured values).

\section{Results of Channel Mapping for Fluvial Reaches of Study Area}

Comparison of channel maps from 1939 to 2009 for the fluvial reaches of the Umpqua, South Umpqua, and North Umpqua Rivers shows that the main channel along these reaches is predominantly single-thread and that its overall planform has remained stable over the 70-year analysis timeframe. Despite the overall channel stability, the proportion of bedrock and gravel flanking the main channel has varied between reaches and over time, with gravel bars historically being most abundant along the Days Creek and Roseburg reaches and bedrock outcrop predominating along the main stem Umpqua River (figs. 18, 19, and 20). Altogether, the Roseburg and Days Creek reaches had more than twice the area of mapped gravel per unit length of channel (13.6 and $17.6 \mathrm{~m}^{2} / \mathrm{m}$, respectively) than the Garden Valley and Coast Range reaches in 2005, where specific bar area was 5 and $5.1 \mathrm{~m}^{2} / \mathrm{m}$, respectively (fig. 18).

Much of the gravel mapped throughout the study area is stored in large $\left(>20,000 \mathrm{~m}^{2}\right)$ point bars, whose positions are fixed by valley geometry (for example, Maupin Bar at FPKM 94.5, fig. 7). Bed-material sediment is also stored in medial bars and numerous small $\left(<2,000 \mathrm{~m}^{2}\right)$ bars (such as those shown in figure 16), but these features formed less than 30 and 6 percent, respectively, of the total bar area in 2005. Like other rivers, reach-average wetted channel width (as measured from channel maps from 2005) increases systematically downstream, from $32 \mathrm{~m}$ on the Days Creek reach to $104 \mathrm{~m}$ on the Coast Range reach (fig. 18). 


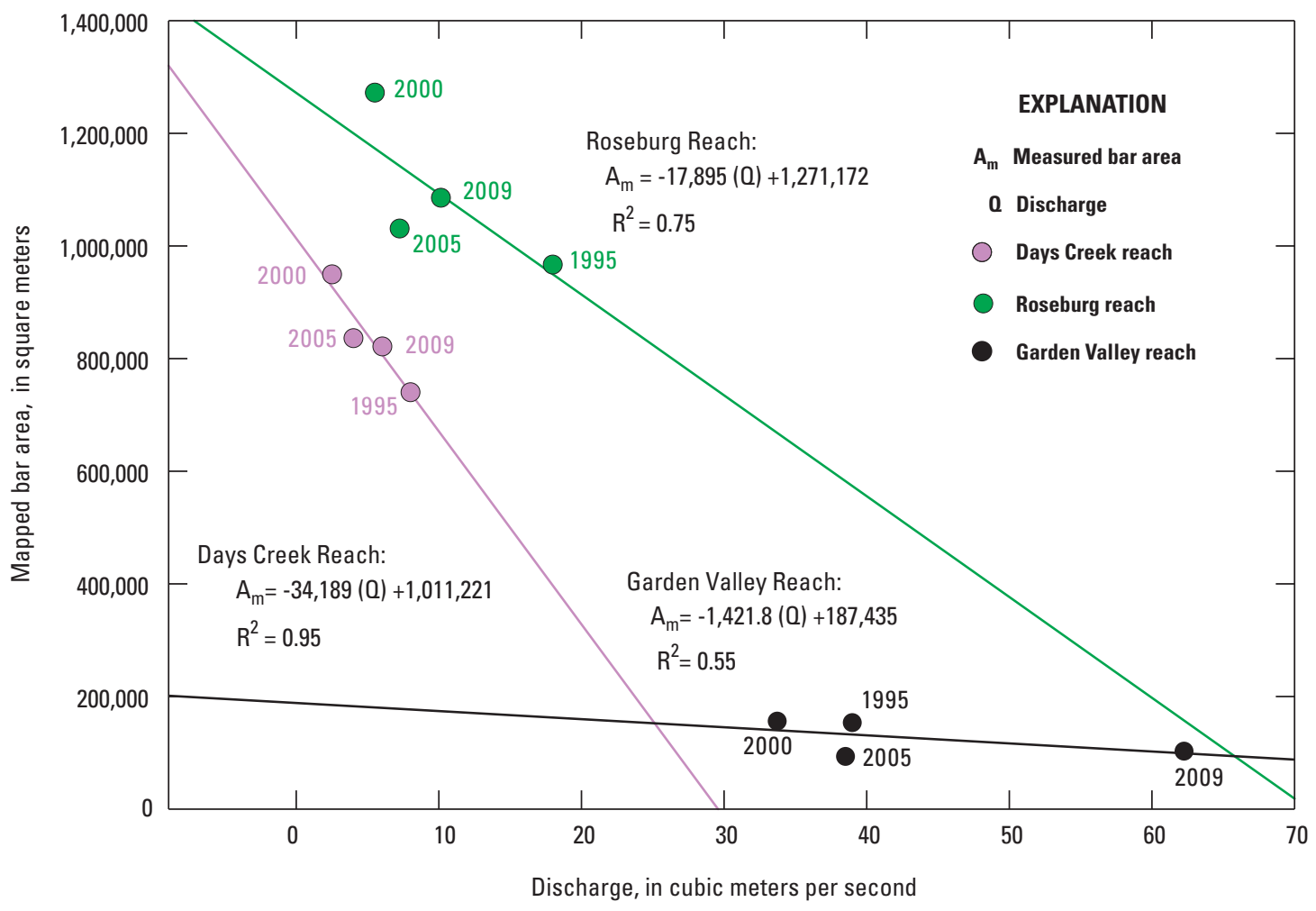

Figure 17. Relation of bar area to discharge in photographs of the Days Creek, Roseburg, and Garden Valley reaches of the Umpqua River, Oregon, 1995-2009. Linear regressions between mapped bar area and photograph discharge (the discharge when the photograph was made) were used to normalize bar areas to a common, reach-specific discharge.

Near its upstream boundary, the South Umpqua River along the Days Creek reach is a mountain stream with a channel width of about $28 \mathrm{~m}$, but along its length, the channel and flood plain widen, and gravel bars increase in size and frequency (fig. 10). Prominent zones of gravel storage along the Days Creek reach include FPKM 250-257, where several large bars, including Days Creek Bar (FPKM 250.1), are located in the apices of sharp bends as the South Umpqua River winds through the resistant rocks of the Klamath Mountains (figs. 10B, 10C, and 18).

Farther downstream, near the boundary of the Days Creek and Roseburg reaches at the confluence of Cow Creek, a series of large bars, including Gazley Bar (FPKM 232, fig. 10) and Lawson Bar (FPKM 230.1, figs. 2G and 9D), have historically been major zones of gravel storage. Other gravel-rich areas of the Roseburg reach are the Myrtle Creek confluence area (FPKM 220-222, encompassing Western Bar and Myrtle Creek Bridge Bar, shown in fig. 16F) and Elk Island (FPKM 180), formed by an overflow channel at a large-amplitude bend (ig. 16D). Although gravel patches less than 2,000 $\mathrm{m}^{2}$ were abundant throughout the Days Creek and Roseburg reaches (accounting for nearly 50 percent of the total number of bars on these reaches), the cumulative area of these features comprised less than 6 percent of the total bar area. These small deposits of gravel typically were mapped in association with bedrock rapids and in narrow strips flanking straight reaches of the channel (for example, Willis Creek Bar, fig. 16E).

In contrast, the Coast Range reach is predominantly a bedrock channel; the reach had more than 4 times the area of exposed bedrock than the Roseburg reach in $2005\left(26.7 \mathrm{~m}^{2} / \mathrm{m}\right.$ compared to $6.4 \mathrm{~m}^{2} / \mathrm{m}$ ) and nearly 10 times the amount of bedrock compared to the Days Creek reach, where the specific bedrock area was $3.1 \mathrm{~m}^{2} / \mathrm{m}$ (fig. 18 and $\underline{19}$ ). The main area of gravel storage in the Coast Range reach lies along a series of incised meander bends between FPKM 90 and 122 (fig. 20), and includes Maupin Bar (FPKM 94.5), the largest bar in the study area above the head of tide $\left(152,270 \mathrm{~m}^{2}\right.$, fig. 7$)$ as well 

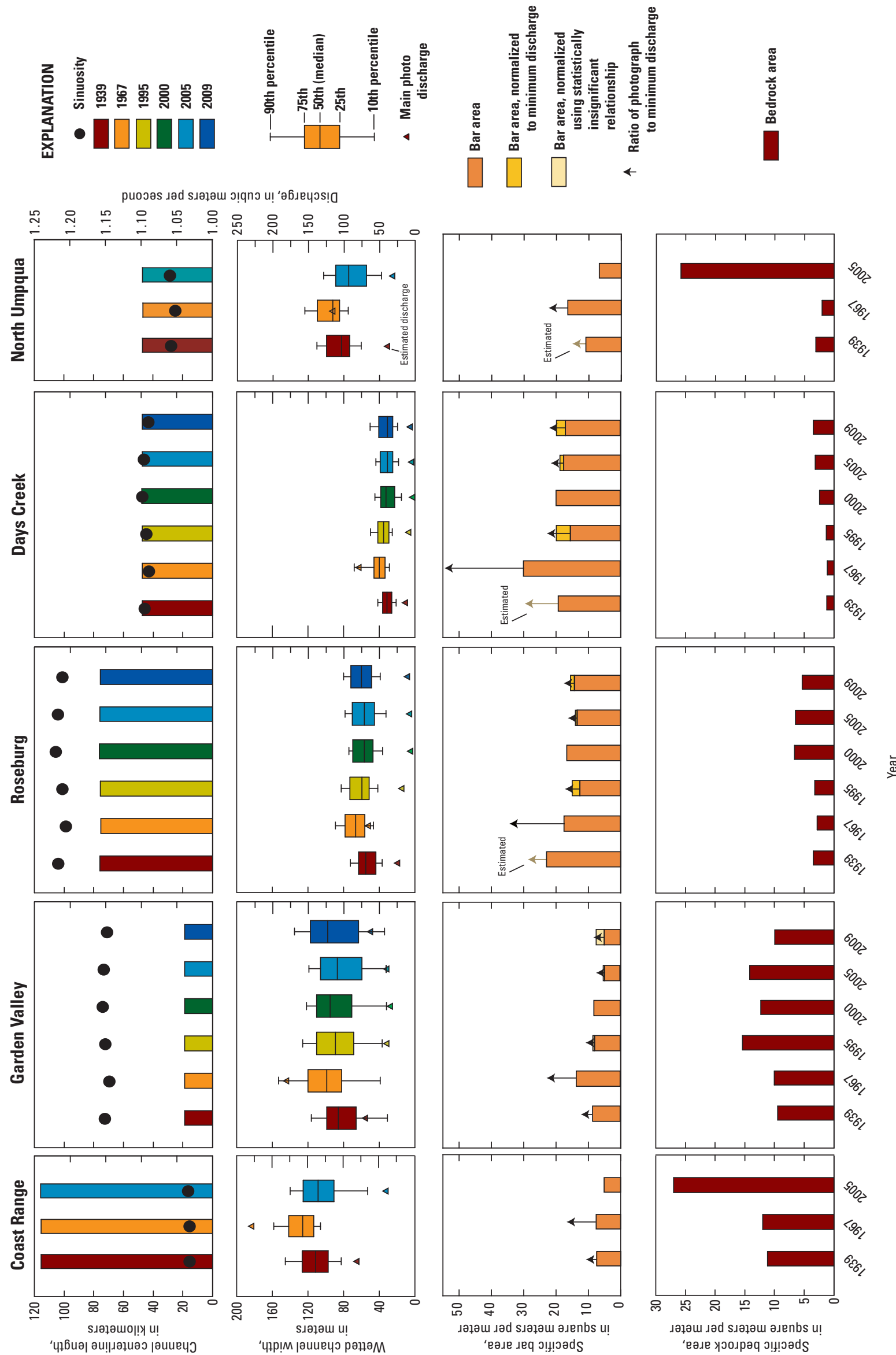

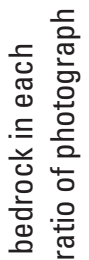

든

कs के

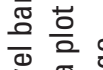

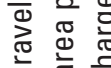

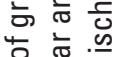

인. $\cong \frac{5}{2}$

त

画

这

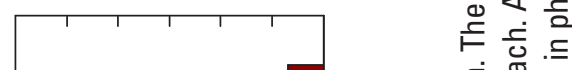

ธ่

बढ

万人

言 $\cong$ 合

氾

ळ

릉ㅎㅁ

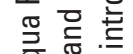

을

与 은

눙

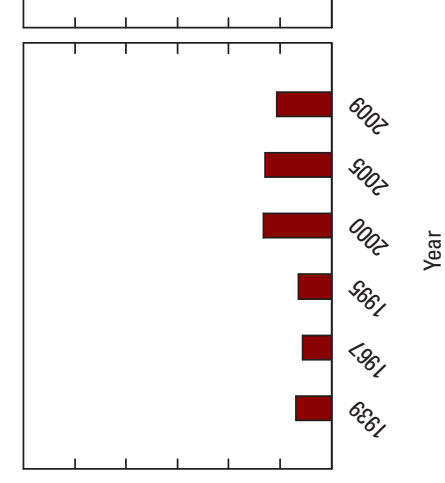

$\stackrel{\square}{\triangle}$

co

는

ब

. क

主吉

한.

表

웅 흠

هे
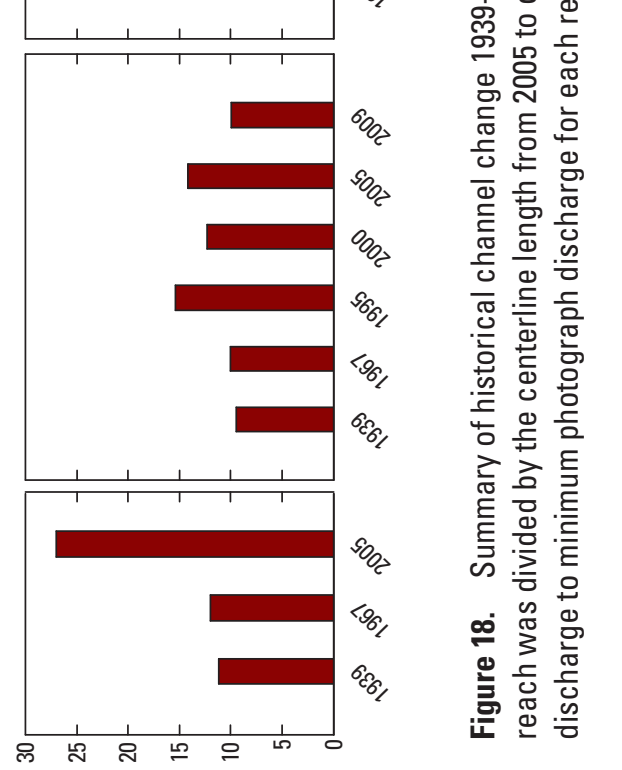

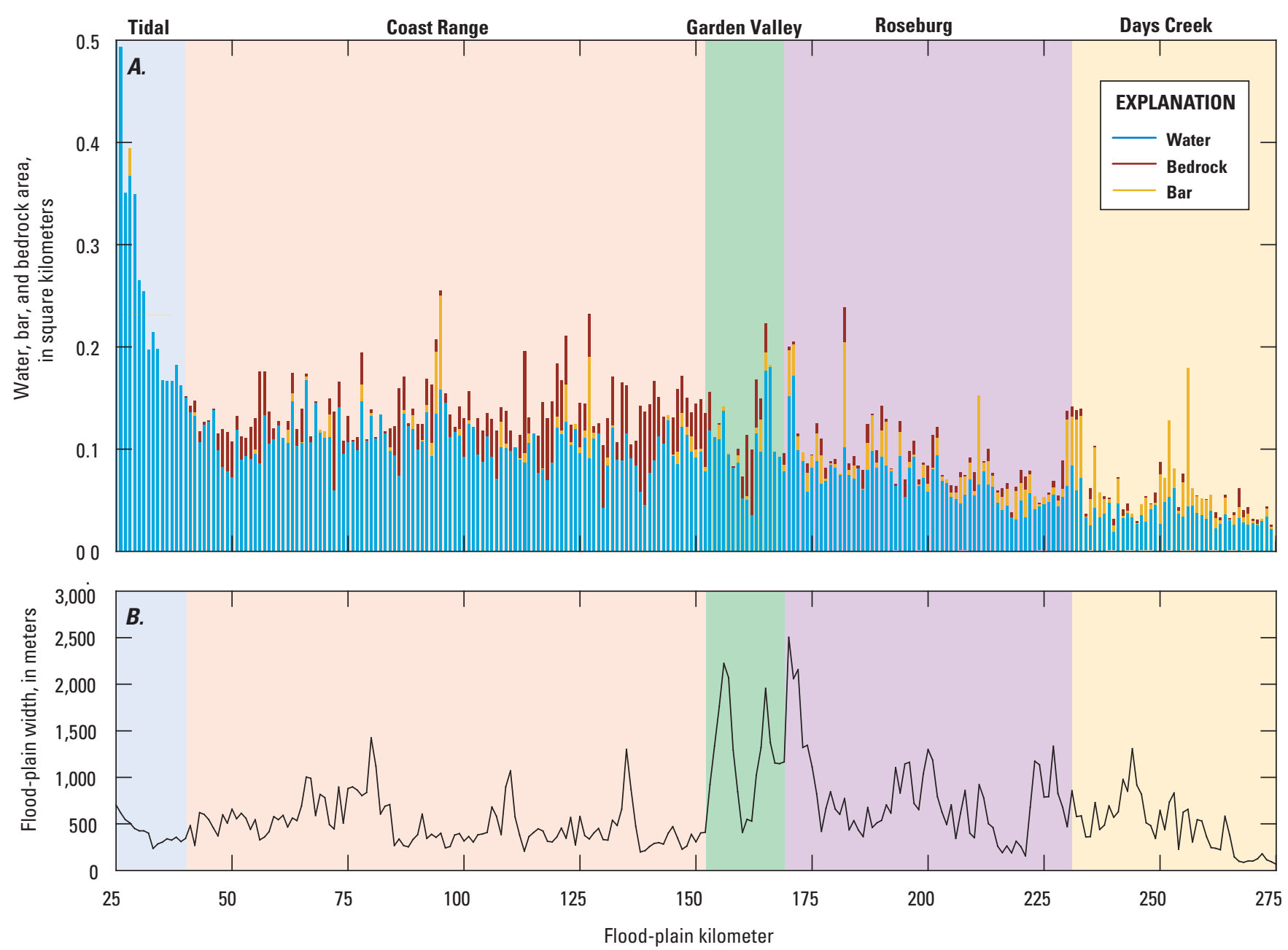

Figure 19. (A) The fraction of water, bedrock, and gravel bars in each flood-plain kilometer transect in the Umpqua and South Umpqua Rivers, Oregon, as mapped from 2005 aerial photographs. Downstream of FPKM 25 in the Tidal reach, channel area increases substantially in the lower Umpqua River estuary. (B) Flood-plain width by flood-plain kilometer.

as Mary's Island (FPKM 122), and the densely forested Myrtle Island (FPKM 125, fig. 7C). Elsewhere, bedrock rapids, locally mantled with a thin veneer of gravel, such as those at Elkton Elementary School and Hutchison Wayside (figs. 16A, $\underline{16 \mathrm{~B}}$, and 19) are common. Many reaches have little or no mappable gravel, including several 5- to 10-km-long sections of the Coast Range reach (ig. 20). Bunch Bar at FPKM 62.5 is the last prominent gravel bar before reaching the expansive fine-grained bars of the lower Tidal reach downstream of FPKM 15.

The Garden Valley reach spans the short distance between the confluence of the North Umpqua and South Umpqua Rivers and the Coast Range reach. This reach had only $5 \mathrm{~m}^{2} / \mathrm{m}$ of gravel along the channel forming 12 mappable gravel bars in 2005 (figs. 18 and 20), the largest of which was
Cleveland Rapids Bar (19,900 $\left.\mathrm{m}^{2}\right)$ at FPKM 164.7. Along the Garden Valley reach, the primary low-flow channel occupies most of the active channel area, although bedrock outcrops are common (fig. 19).

In 2005, the active channel of the North Umpqua reach resembled the Coast Range reach, both in terms of bar area $\left(6.7 \mathrm{~m}^{2} / \mathrm{m}\right)$ and bedrock area $\left(25.8 \mathrm{~m}^{2} / \mathrm{m}\right)$, although the wetted channel is much narrower on the North Umpqua reach (reach average width was $72 \mathrm{~m}$ ) (figs. 11 and 18). Like the Coast Range reach, there are only a few large, gravel bars in the North Umpqua reach, such as those at Whistlers Bend (NUFPKM 33.5, fig. 11B). Similar to the Umpqua River downstream of the confluence, the North Umpqua River channel primarily consists of a series of bedrock rapids, locally mantled with small gravel patches. 


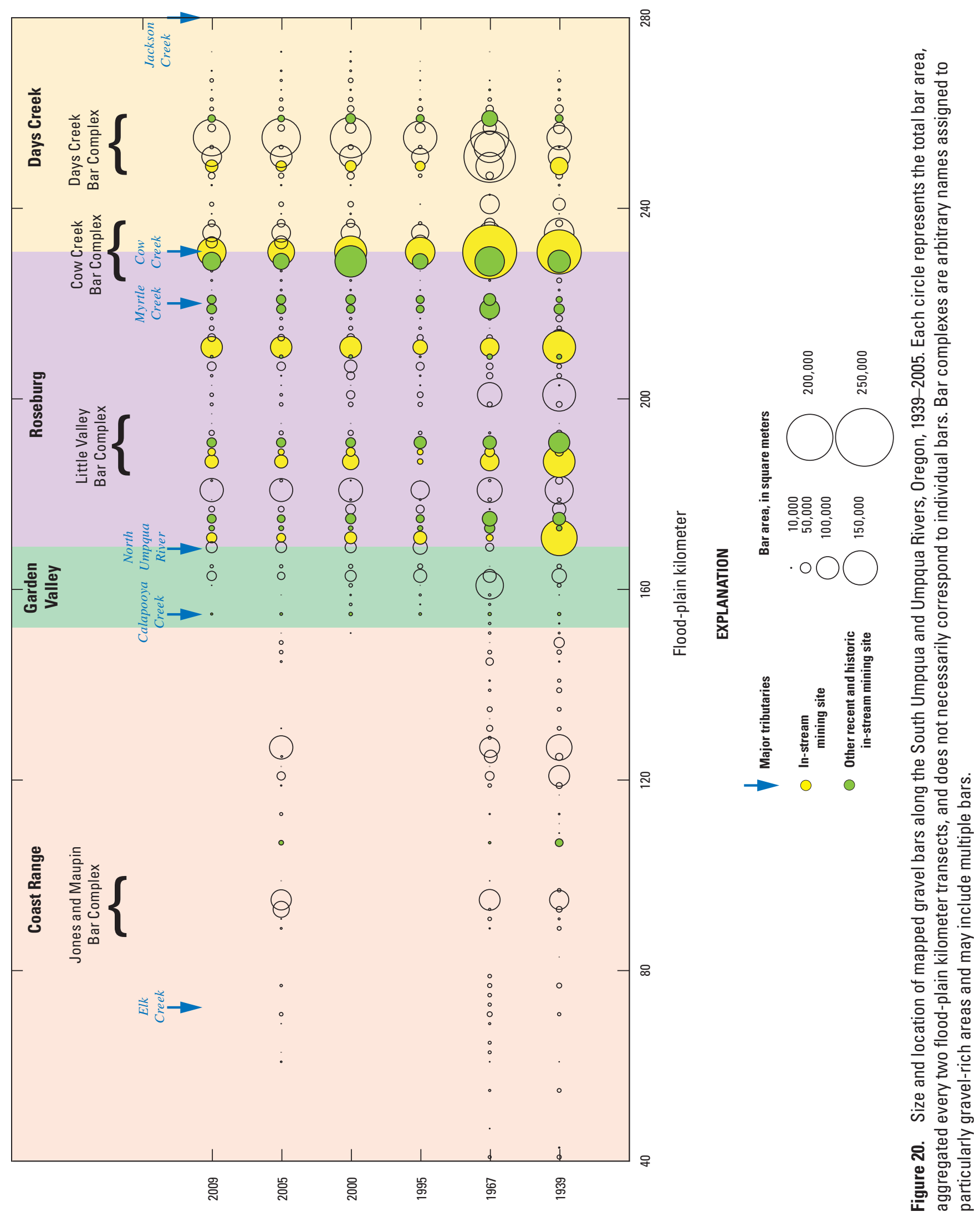


The most evident temporal changes in active channel conditions for all five fluvial reaches between 1939 and 2005 are the large net reduction in bar area. Between 1939 and 2005, the total bar area decreased 29 percent from 4.22 to $2.87 \mathrm{~km}^{2}$ (figs. 18 and 20). However, the temporal trend of decreasing bar size has not been monotonic; total bar area above the head of tide increased 11 percent between 1939 and 1967, and aerial photographs from 1967 show substantial deposition along nearly all bars in the study area. This increase in bar area, however, was more than compensated by a 39-percent decrease in bar area between 1967 and 2005 (fig. 18).

These changes in bar area resulted from various transformations within the flood plain and channel system (fig. 21). Areas of new bars resulted primarily from scouring and covering pre-existing flood-plain surfaces with fresh gravel deposits and the growth and formation of gravel bars into areas formerly covered by water (fig. 21). Only small areas of bedrock were subsequently covered by gravel to form new areas of bars (fig. 21). Areas of lost gravel bars chiefly became water, especially during the 1939-67 period, but many bar areas were evidently scoured to bare bedrock outcrops, especially in the 1967-2005 period (fig. 21).

Other overall findings for the five fluvial reaches are that (1) centerline length along most reaches has remained very stable, with little temporal variation in sinuosity, and (2) channel width has varied only slightly, with no apparent systematic trends except that wetted width for all reaches was greatest in 1967 (when the flow at the time of the aerial photographs was significantly greater) (fig. 18). Inspection of individual photograph sets shows that despite similar overall trajectories, each of the reaches has displayed a unique set of transformations during the 70-year analysis interval.

Historical changes to bar and channel morphology have been greatest along the gravel-rich sections of the Roseburg and Days Creek reaches, where large and closely spaced gravel bars provide more opportunities for adjustments to channel and bar morphology than the primarily bedrock-flanked reaches of the main stem Umpqua River. On these upper reaches, many gravel bars in 1939 had overflow channels and scoured patches of bare gravel flanked by areas with mature shrubs (such as Umpqua Sand and Gravel Bar, FPKM 171.4, fig. 22B). Aerial photographs from 1967 show that many of these partially vegetated 1939 bars, along with their adjacent flood-plain surfaces, had been substantially scoured and stripped of vegetation (fig. 22B ). New bars also formed along the channel between 1939 and 1967; approximately 15 percent of new bars in the Roseburg and Days Creek reaches had been previously mapped as water in the 1939 photographs. In total, between 1939 and 1967, scour and fresh deposition along upper bar surfaces combined with bar growth into former low-flow channel areas (such as that shown at FPKM 251-255, fig. 22C) increased total bar area on the Days Creek reach by 55 percent, from 19.3 to $31.8 \mathrm{~m}^{2} / \mathrm{m}$.

Despite bar growth in some areas, the Roseburg reach was the only reach in the study reach to show a net decrease in mapped gravel between 1939 and 1967. Many bars present in the 1939 photographs are wholly absent or substantially eroded in the 1967 photographs (such as Umpqua Sand and Gravel Bar, fig. 22B), reducing the specific bar area from 23 to $17.6 \mathrm{~m}^{2} / \mathrm{m}$. Between 1967 and 1995, the bar area decreased 28 and 48 percent, respectively, on the Roseburg and Days Creek reaches, primarily as a result of vegetation colonization and consequent mapping as "flood plain" for the 1995 photographs of the high-elevation, freshly scoured surfaces apparent in the 1967 photographs. Also evident was the erosion of many of the bare, low-elevation bars present in the 1967 photographs, transforming those areas to both "water" and "bedrock" (figs. 21 and 22).

Between 1995 and 2000, a period spanning the floods of November 1996-January 1997, the area of mapped gravel increased by approximately 30 percent on the Days Creek and Roseburg reaches (figs. 18 and 20) as low-elevation bars were created and enlarged (figs. 23E and $\mathrm{F}$ ). In most places, the high-elevation surfaces that previously appeared bare and floodswept in the 1967 photographs, but were colonized with vegetation by 1995, did not show obvious signs of erosion during the period 1995-2000, except where high flows had scoured overflow channels (such as those at Days Creek Bar, FPKM 250, fig. 22C). During the low-flow period of 20002005 (Bumbaco and Mote, 2010), bar area decreased from 12 and 19 percent, respectively, on Days Creek and Roseburg reaches (figs. 18 and 20). This decrease was mainly by erosion of low-elevation bars present in the 2000 photographs, but absent (replaced by water) in the 2005 photographs. Comparison of the 2005 and 2009 photographs shows little net change in bar area, and channel maps from both times depict similar channel conditions (fig. 18). 


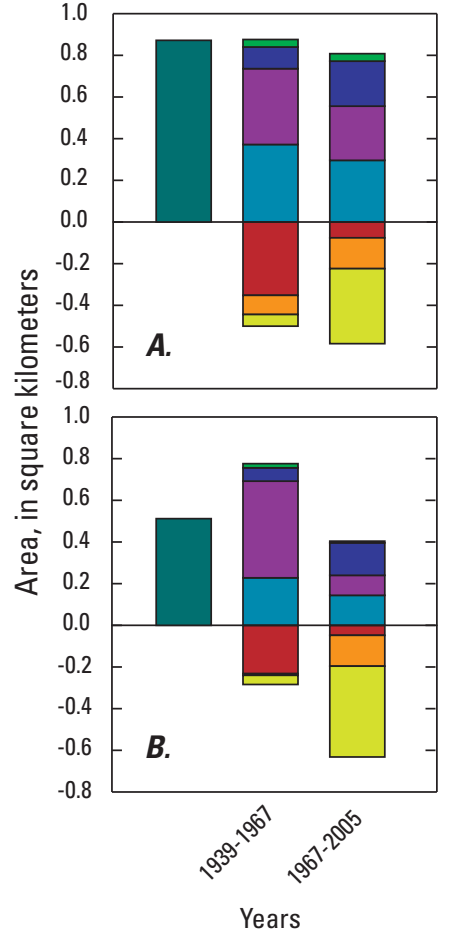

\section{EXPLANATION}

ए 1939 bar area

No transformation $\square$ Bar to bar
Increases in bar area $\square$ Bedrock to bar

Water to bar

Decreases in bar area

Bar to water

$\square$ Bar to bedrock

$\square$ Bar to flood plain
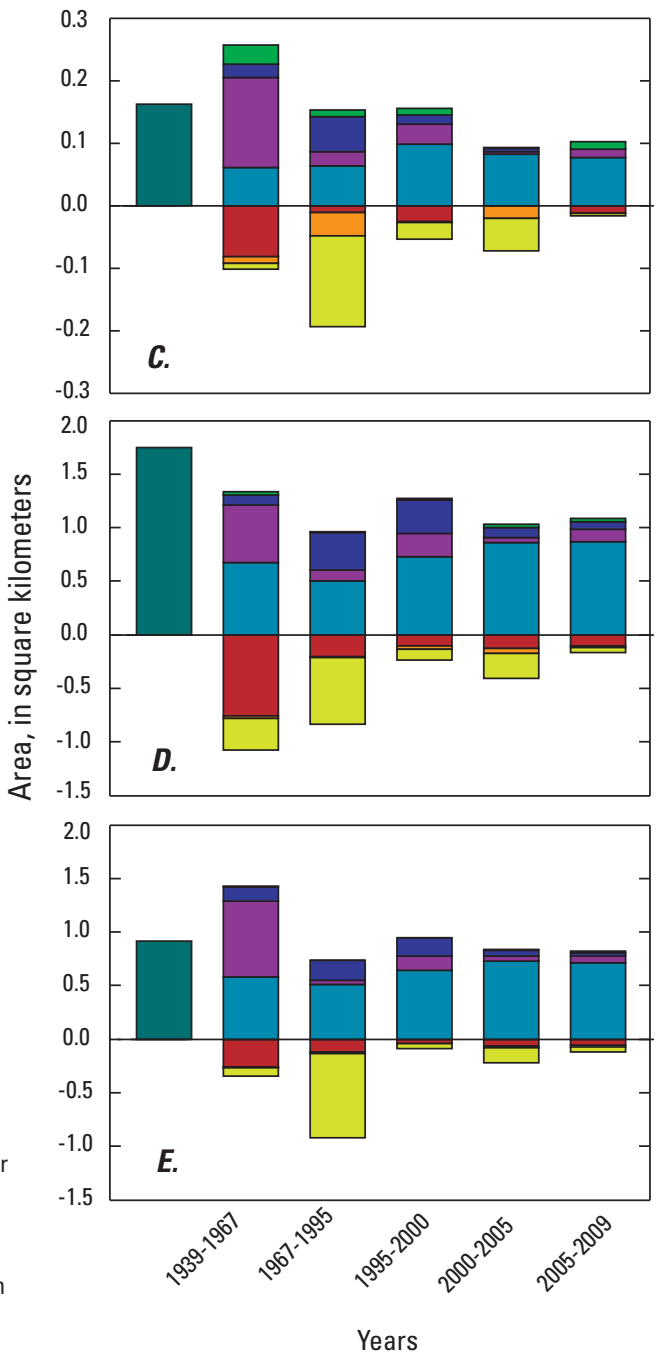

Figure 21. Reach-segregated changes in bar area in the Umpqua River basin, Oregon, 1939-2005. Positive balance represents net bar area in each time period separated according to areas that were previously mapped as bars, and newly created bars that were previously mapped as water, flood plain, or bedrock. Negative balances represent total decreases in bar area, separated into areas that became water, bedrock, or flood plain. $(A)$ Coast Range, $(B)$ North Umpqua, $(C)$ Garden Valley, $(D)$ Roseburg, $(E)$ Days Creek. 

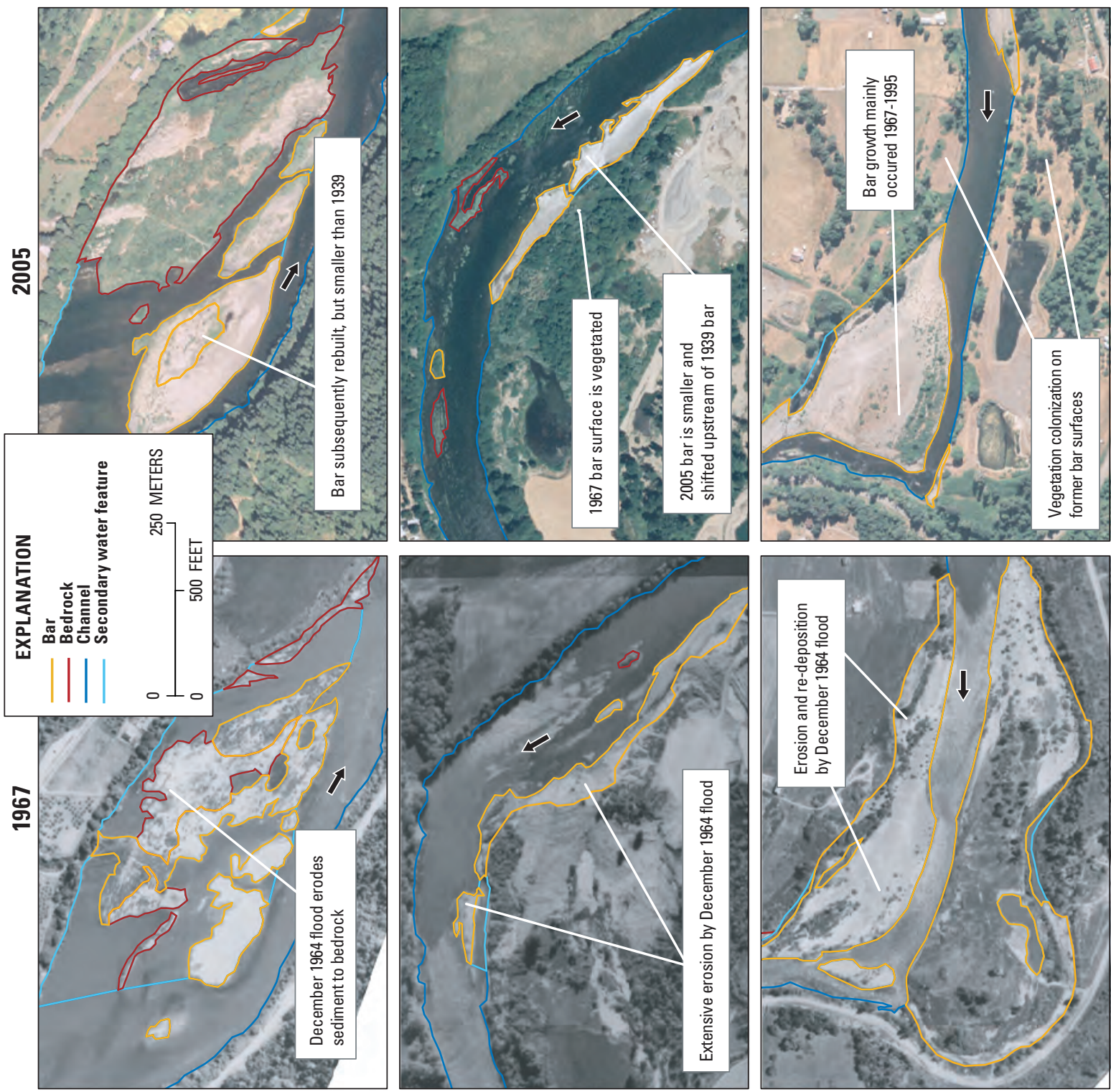

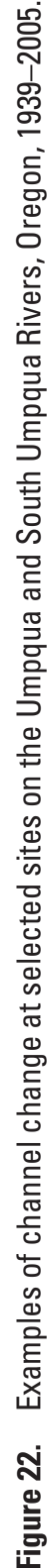
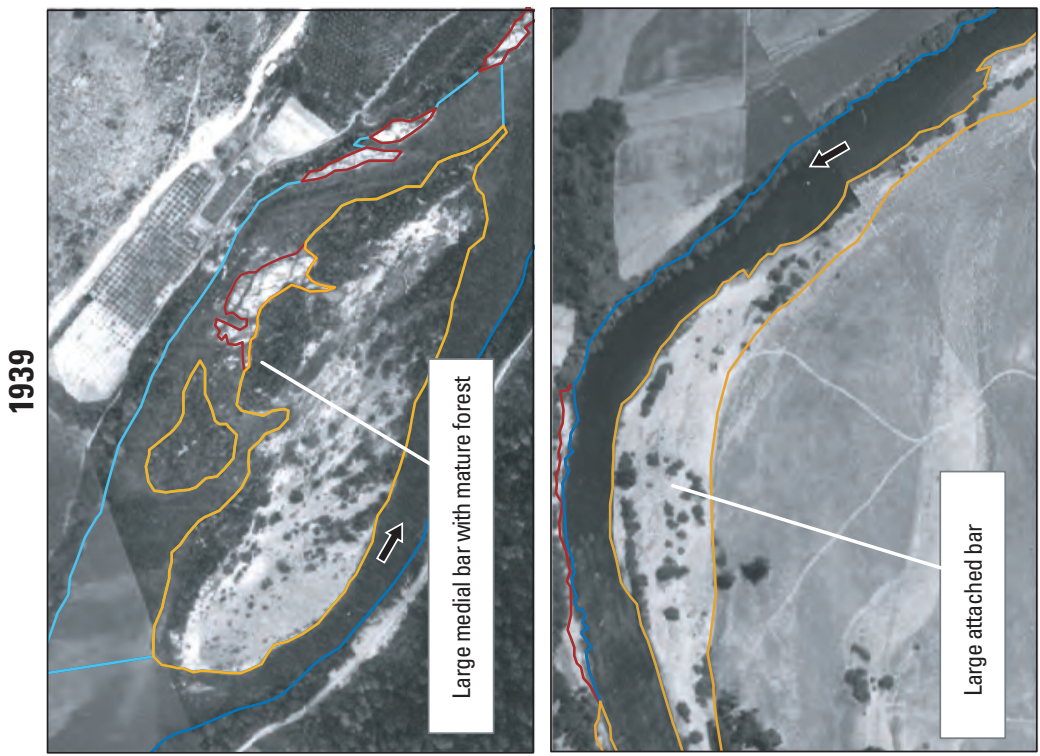

E' IZL WYdd 'deq pue|s| S,AdeW ' $\forall$

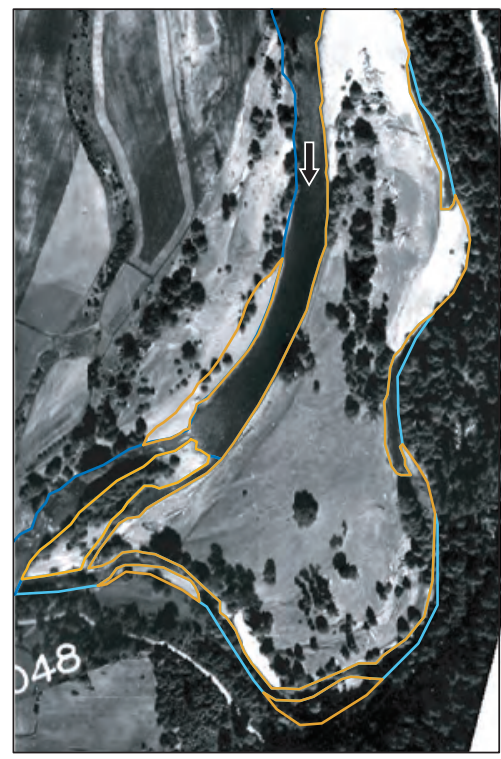

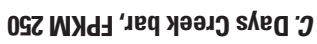



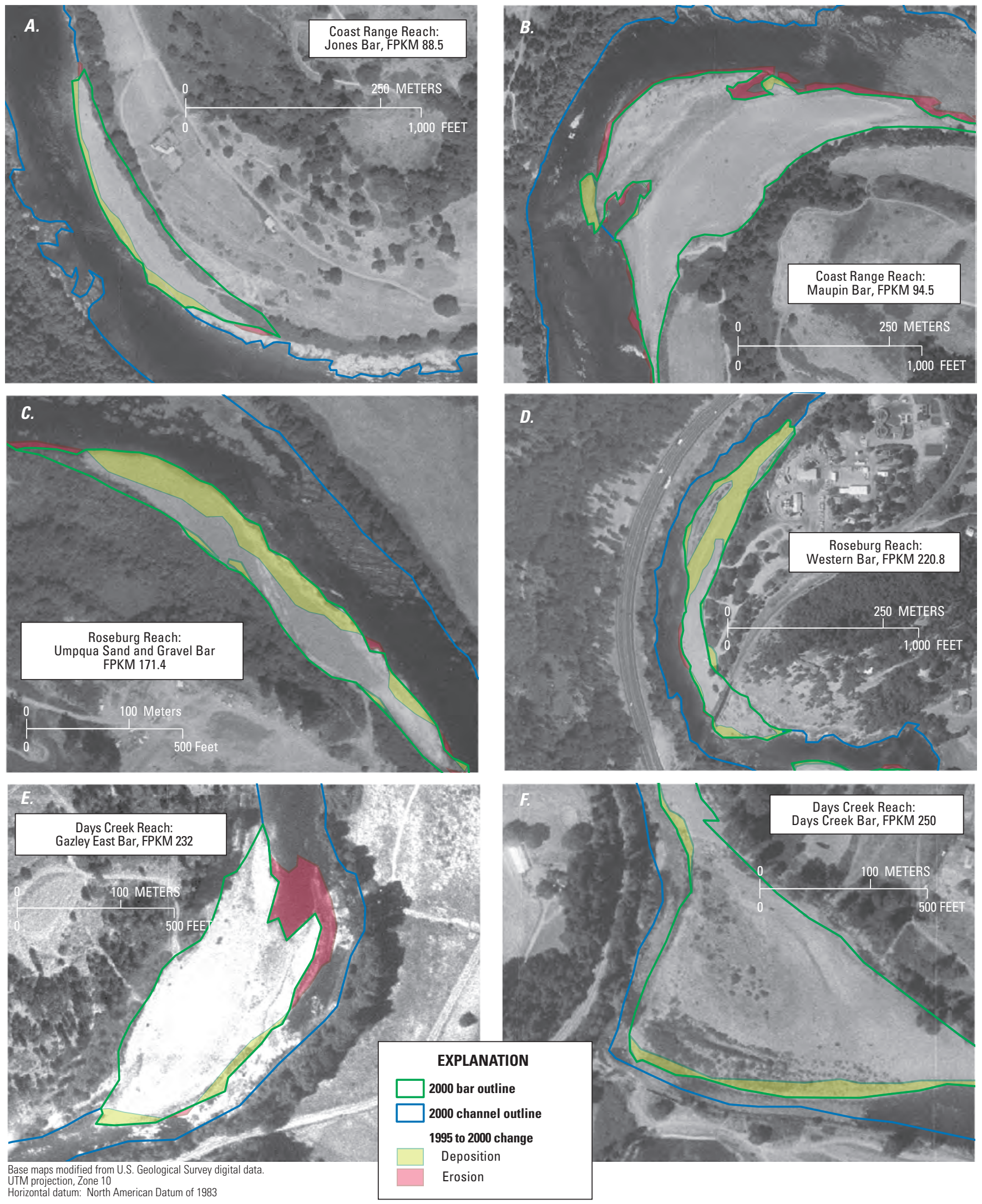

Figure 23. Changes in bar morphology between 1995 and 2000 for select sites on the Umpqua and South Umpqua Rivers, Oregon. Mapping (1995 and 2000) and aerial photographs (2000) span the December 1996 flood. 
Channel change on the Coast Range, Garden Valley, and North Umpqua reaches followed similar trends as the Days Creek and Roseburg reaches, but with several distinctions. Despite local areas where bars were stripped to bedrock (such as Mary's Island at FPKM 121.3, fig. 22A), bar area on the Coast Range reach remained similar between 1939 and 1967, whereas bar area increased 51 percent in the North Umpqua reach during the same period (fig. 18). Many of these newly formed 1967 bars were replaced by areas of bedrock by 2005, causing an 11-fold increase in near-channel bedrock between 1967 and 2005 along the North Umpqua reach. Similarly, bedrock area within the Coast Range reach increased 124 percent (figs. 18 and 21). During the same period, bar area decreased 59 percent from 16.5 to $6.7 \mathrm{~m}^{2} / \mathrm{m}$ on the North Umpqua reach, and 32 percent from 7.6 to $5.1 \mathrm{~m}^{2} / \mathrm{m}$ on the Coast Range reach (fig. 18). Trends in bar area on the Garden Valley reach most closely follow that of the Days Creek reach, but the overall magnitude of change during each time period is less than for the more gravel-rich South Umpqua reaches (fig. 18). Like other reaches, bar area on the Garden Valley reach was greatest in 1967, increasing 58 percent between 1939 and 1967, but then decreasing 40 percent between 1967 and 1995, primarily as newly formed bars were eroded to bedrock (figs. 18 and 21). Bar area on the Garden Valley reach remained about stable from 1995 to 2000, then decreased another 40 percent from 2000 to 2005 and showed little change from 2005 to 2009 (figs. 18 and 21).

Temporal and spatial patterns of historical channel change along the Umpqua River study area probably result from channel response to varying magnitude floods and possibly dam construction, although differences in discharge at the time of the photographs also affect the map patterns. For all fluvial study reaches except the Roseburg reach, mapped gravel bar area was greatest in 1967 (fig. 18) despite the higher flows in the 1967 photographs, which would be expected to cover many low bars. The large area of 1967 bars is likely the result of erosion and redeposition associated with the large flood of December 1964, which had a recurrence interval of approximately 100 years in most places in the study area (fig. 5). Similarly, bar area probably increased in the Roseburg reach between 1939 and 1967, but it was not evident because of the much higher flow in this reach at the time of the 1967 photographs (fig. 18; table 6).

Throughout the study area, decreasing gravel-bar area between 1967 and 1995 probably was due to a combination of (1) vegetation colonization and fine sediment accumulation along floodswept areas from the December 1964 flood and (2) erosion of low-elevation bars (fig. 21). Minor increases in bar area from 1995 to 2000 on the Roseburg, Days Creek, and Garden Valley reaches probably are attributable to
(1) the floods of 1996-97 and (2) the low range of discharges depicted in the aerial photographs from 2000, which biases the channel maps from 2000 toward high bar areas (fig. 18, table 6). When adjusted for flow, the increase in bar area within the Days Creek and Roseburg reaches is only 2-7 percent (fig. 18). Because peak discharges of the 1996-97 floods on the South Umpqua River were 23-39 percent smaller than the December 1964 event (fig. 5, table 1), the 1996-97 floods mainly modified and created low-elevation bars and did not cause widespread erosion like that associated with the December 1964 flood (figs. 23E and 23F). Decreases in bar area during the low-flow period of 2000-2005 are likely also due in part to the low discharge of the 2000 photos, but also to erosion because the adjusted values of bar area are also lower in 2005 for all study reaches (fig. 18; table 6).

Although a December 2005 flood had a similar peak discharge as that of December 1996, bar areas did not change substantially during this period. Evidence for the December 2005 flood is mostly from bare gravel bars present in both the 2005 and 2009 photographs, where the 2009 photographs show recently scoured surfaces and overflow channels (fig. 23). One possible explanation for the difference in channel response between the 1995-2000 and 2005-2009 periods is that although the 1996 and December 2005 floods had similar peak discharge, water year (WY) 1996 had three flows exceeding the 2-year flood discharge of 1,293 $\mathrm{m}^{3} / \mathrm{s}$ (as measured at the Brockway USGS streamflow gage), whereas the December 31, 2005, flood was the only one to exceed this value during WY 2006.

Like other reaches, the North Umpqua River had a substantial net loss of bar area during 1939-2005, especially between 1967 and 2005, when mapped gravel deposits diminished by nearly 60 percent (fig. 18). This decrease, as well as the associated 115 percent increase in exposed bedrock observed on the North Umpqua reach between 1967 and 2005, probably was at least partly because of construction of hydropower dams in 1952-55, which trap bed-material sediment from 32 percent of the North Umpqua River basin. Although the difference in discharge at the time of the two sets of photographs may account for some of the difference in bar and bedrock area, inspection of individual bar polygons from 1967 and 2005 shows that 49 percent of the bar area from 1967 for the North Umpqua reach was scoured to bedrock by 2005. Similar transformation of gravel bars to bedrock areas during this period downstream of the confluence of the North Umpqua and South Umpqua Rivers in the Garden Valley and Coast Range reaches may indicate that diminished sediment supply for the North Umpqua River has decreased bar area in these downstream reaches as well. 
Historical patterns of bar evolution also indicate that small and thin patches of gravel deposited along bedrock rapids were often transient zones of bed-material storage, whereas larger bars, which generally formed at large bends in the valley bottom, provide longer term storage for bed-material sediment. Unlike the smaller gravel patches, the locations and approximate areas of larger bars have persisted for the length of the photographic record (fig. 20), even though the upper bar surfaces were scoured and subsequently revegetated following the flood of December 1964, and low-elevation bar margins increased and contracted in response to the 1996-97 floods and intervening low-flow periods.

\section{Results of Vegetation Density Mapping for Fluvial Reaches}

Repeat mapping of vegetation density on gravel bars reveals patterns of disturbance and recovery that primarily were caused by large floods, in particular the large flood of December 1964. Vegetation density maps created for the Days Creek, Roseburg, and Garden Valley reaches from 1995, 2000, 2005, and 2009 show that floods in 1996-97 and 2005 also influenced vegetation density on gravel bars, although these smaller floods had less effect than the December 1964 flood (fig. 24).

In 1939, about 75 percent of the total bar area along the fluvial reaches of the Umpqua, South Umpqua, and North Umpqua Rivers was covered in moderate to dense vegetation. Aerial photographs from this period show that the dominant vegetation in this time period were grasses, with woody shrubs scattered over entire bar surfaces but becoming increasingly dense and accompanied by mature trees along the upper bar surfaces (for example, Days Creek Bar, FPKM 250, fig. 22C). By 1967, the area of bare gravel had increased 53-234 percent following the December 1964 flood, which scoured vegetated surfaces and created new bars (figs. 24 and 25). The 1964 flood also apparently carved overflow channels through relic floodplain-swales, causing remnant patches of floodswept, vegetated flood plain to be incorporated into the active channel. These bare surfaces were later colonized by vegetation or eroded, causing the area of bare gravel to decrease by 40-70 percent from 1967 to 2005 (figs. 24 and 25), as exemplified by Days Creek Bar (fig. 22C). Between 1967 and 1995, the area of bare gravel decreased as (1) vegetation colonized the floodplain and upper bar surfaces scoured by the 1964 flood, and (2) fluvial erosion

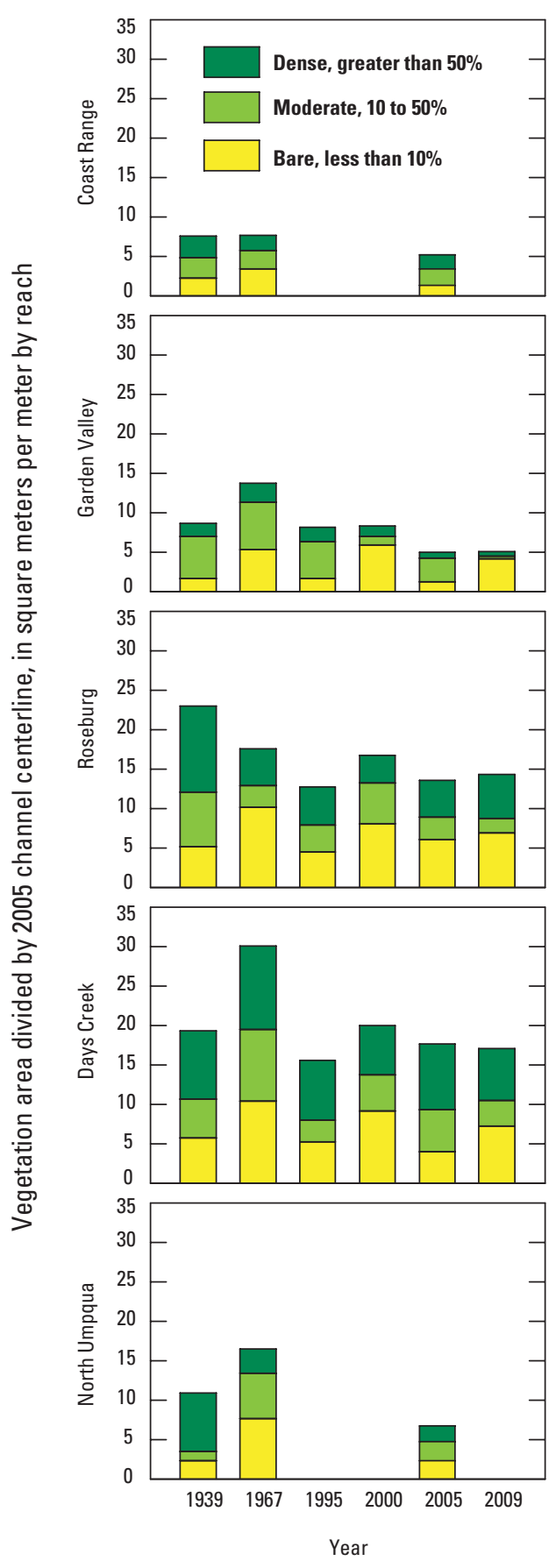

Figure 24. Historical changes in vegetation density within the active channel for fluvial reaches of the Umpqua River basin, Oregon, 1939-2009. Coast Range and North Umpqua reaches were mapped only in 1939, 1967, and 2005. 
trimmed the bare, low-elevation bars. The floods of November 1996 to January 1997 increased the area of bare and moderately vegetated bars, as some densely vegetated areas were scoured and new bars were created. The Roseburg, Days Creek, and Garden Valley reaches show substantial ( $>70$ percent) increases in the area of bare gravel from 1995 to 2000 in conjunction with decreases of about 20-30 percent in the densely vegetated bars. Between 2000 and 2009, total bar area on the Days Creek and Garden Valley reaches remained similar, but the area of bare and moderately vegetated bars fluctuated as vegetation colonized surfaces flooded during winter of 1996-97, and was later scoured (presumably) by the flood of December 2005. Although the bare bars on the Roseburg reach experienced a similar overall disturbance and recovery pattern from 2000 to 2009, the magnitude of fluctuation on this reach was much less than for other reaches, with the area of bare gravel remaining relatively high, even during the relatively dry period of 2000-2005 (fig. 24).

\section{Oblique Photograph Matching}

Repeat long-term ground-based photography is useful for qualitatively evaluating historical changes to landscapes and vegetation because it provides a direct comparison of ground conditions, commonly extending back several decades prior to earliest aerial photography (for example, Skovlin and others, 2001; Webb and others, 2007). Here, we matched six historical photographs of the Umpqua River from the early 20th century for the dual objectives of (1) identifying areas of obvious change in channel conditions, particularly changes in bed-material storage and (2) evaluating changes in riparian vegetation.

Scanned historical photographs of the South Umpqua and North Umpqua Rivers were acquired from the Douglas County Museum. The locations from which these photographs were taken were determined from notes that accompanied the photographs, along with modern aerial photography and topographic maps (appendix A). During summer 2009, the historical photographs were approximately matched, and the resultant oblique images

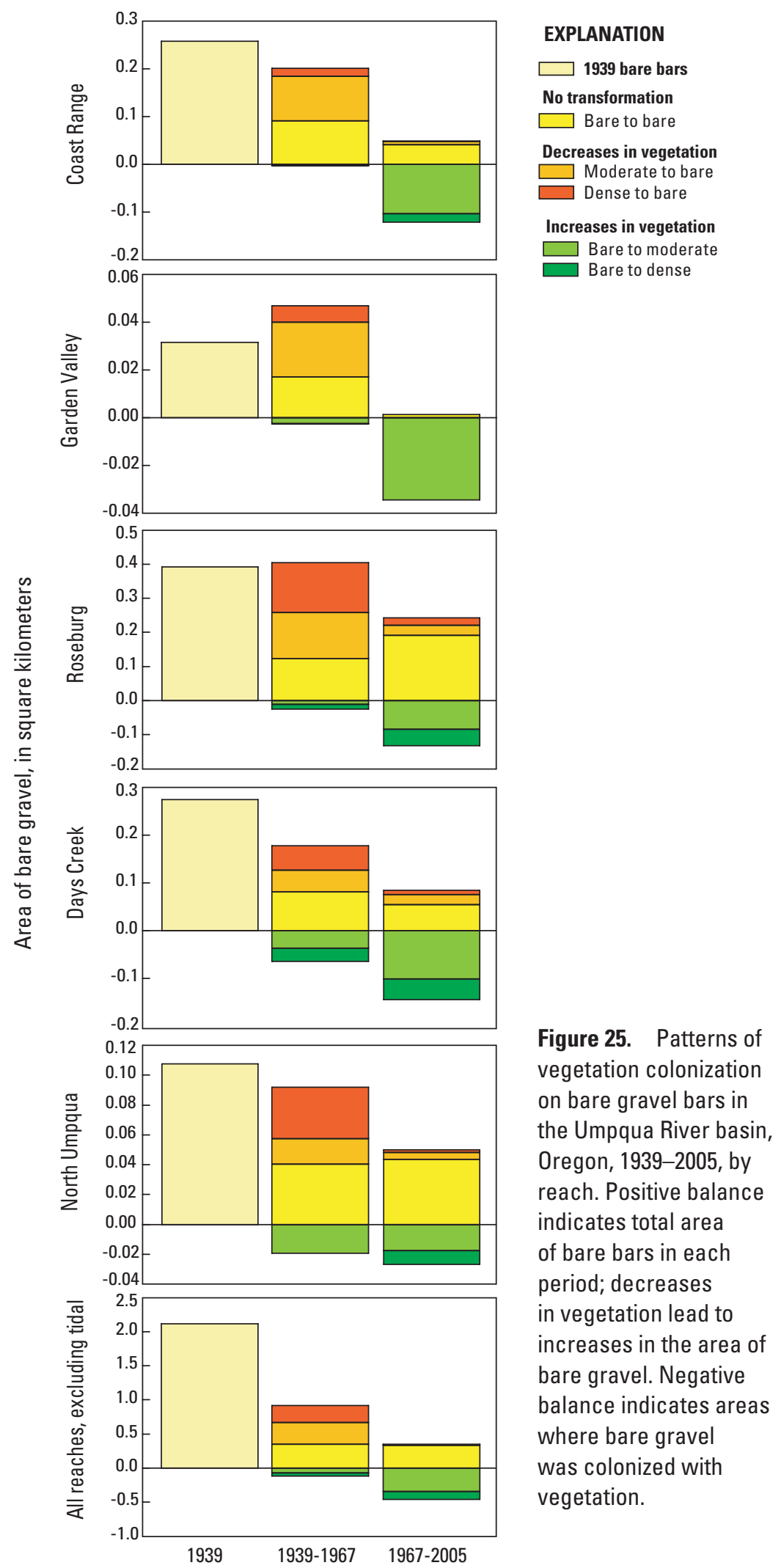


were cropped and resized to approximate the field of view of the historical photographs. In some instances, the original photograph site could not be reoccupied precisely because of vegetation growth, structure, or landform changes, but the approximate match still qualitatively indicates changes to channel and vegetation conditions.

Repeat land-based photographs of the South Umpqua and North Umpqua Rivers show little variation in channel planform or bar characteristics over the past $70+$ years at the three sites (fig. 26A). At Myrtle Creek Bridge (FPKM 219.9), the bar along the left bank appears very similar in 1925 and 2009, as both photographs show a thin mantle of gravel overlying bedrock, but with perhaps slightly more gravel evident in the 2009 photograph (fig. 26B). The confluence of the North Umpqua and South Umpqua Rivers near Singleton Park (FPKM 168.4) also changed little between 1925 and 2009, as the bar along the right bank of the main stem Umpqua River has similar size, shape, and texture in both photographs (fig. 26). Likewise, the photographs from 1925 and 2009 at Booth Bridge on the North Umpqua River show negligible change in bed-material characteristics, as both photographs show thin patches of gravel overlying channel-adjacent bedrock (fig. 26C).

More noticeable is the overall increase in riparian vegetation (fig. 27). Changes in riparian vegetation were most apparent along the South Umpqua River, where vegetation encroachment was evident at all photograph matching sites. At the Winston site, the vegetation in the photograph from 1929 primarily consists of low grass and sparse woody shrubs, but in 2009, the site was densely vegetated, such that trees and shrubs obscured the field of view from the historical photograph location (fig. 27A). At the Rice Creek covered bridge site, the density and character of the bank and flood-plain vegetation remained similar from 1929 to 2009, but herbaceous vegetation had established along the lowelevation bedrock outcrop within the active channel (fig. 27B). Repeat photographs of Whistler's Bend (NUFPKM 33.1) on the North Umpqua River show that trees along the stream corridor had matured and become denser during the 20th century (fig. 27C). These widespread increases in vegetation density in part reflect decreasing flood magnitude (fig. 5), and possibly less direct disturbance of riparian zones during the last few decades.

\section{Comparison of 20th Century Channel Maps with 1854 General Land Office Surveys}

The earliest comprehensive maps of the Umpqua River system were produced by the General Land Office (GLO) in the 1850s as the GLO surveyed public lands in Oregon (as summarized by Atwood, 2008). Although the primary purpose of this mapping was to establish the Township, Range, and Section lines of the Public Land Survey System (PLSS), some of the maps include detailed surveys of the bank lines of larger rivers (a surveying process called meandering [Atwood, 2008]). Although gravel bars and other river features were not systematically mapped as part of the basic PLSS or meander surveys, some GLO maps include prominent gravel bars, rapids, or other local features that can be compared against modern channel maps. Additionally, the survey notes accompanying the maps include descriptions of channel features that are useful for determining changes to channel character over time. Because differences in map quality and detail preclude systematic comparison of the GLO maps with 20th century maps, the GLO maps and survey notes were used to assess general changes in channel conditions. 
A. Myrtle Creek Bridge, South Umpqua River, FPKM 219.9, 1925-2009
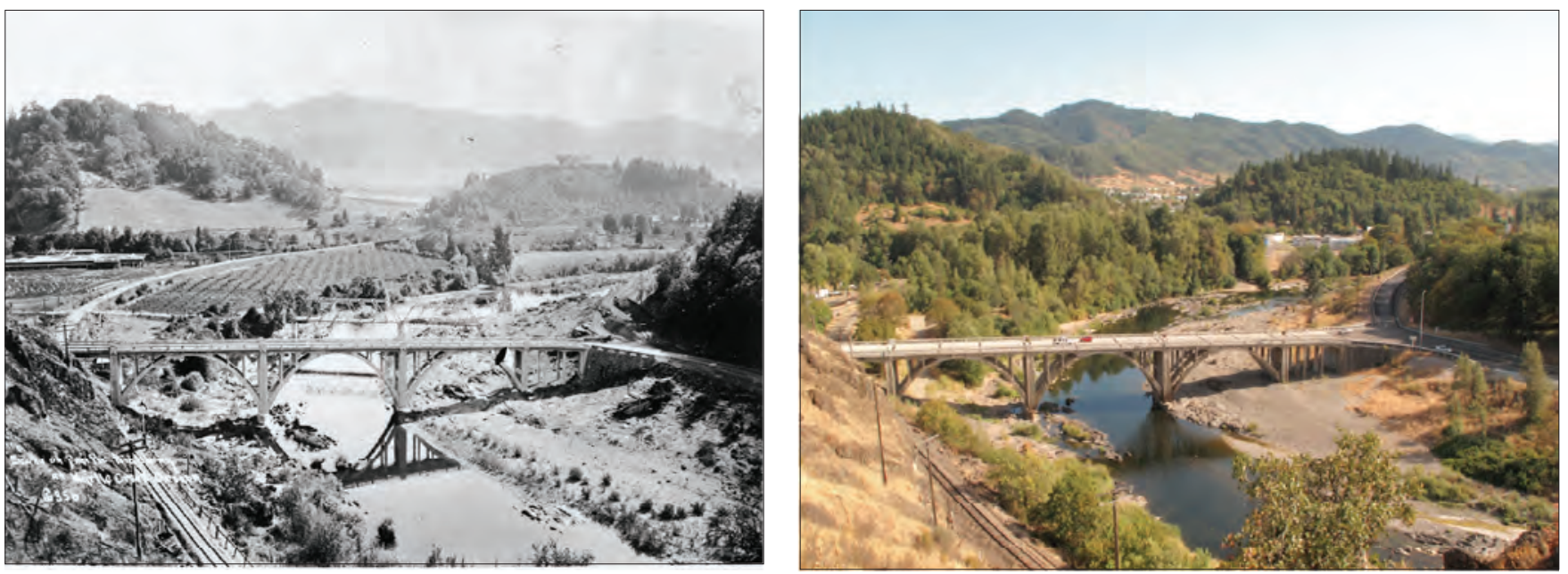

B. Confluence of the South Umpqua and North Umpqua Rivers, near Singleton Park, FPKM 168.4, 1925-2009
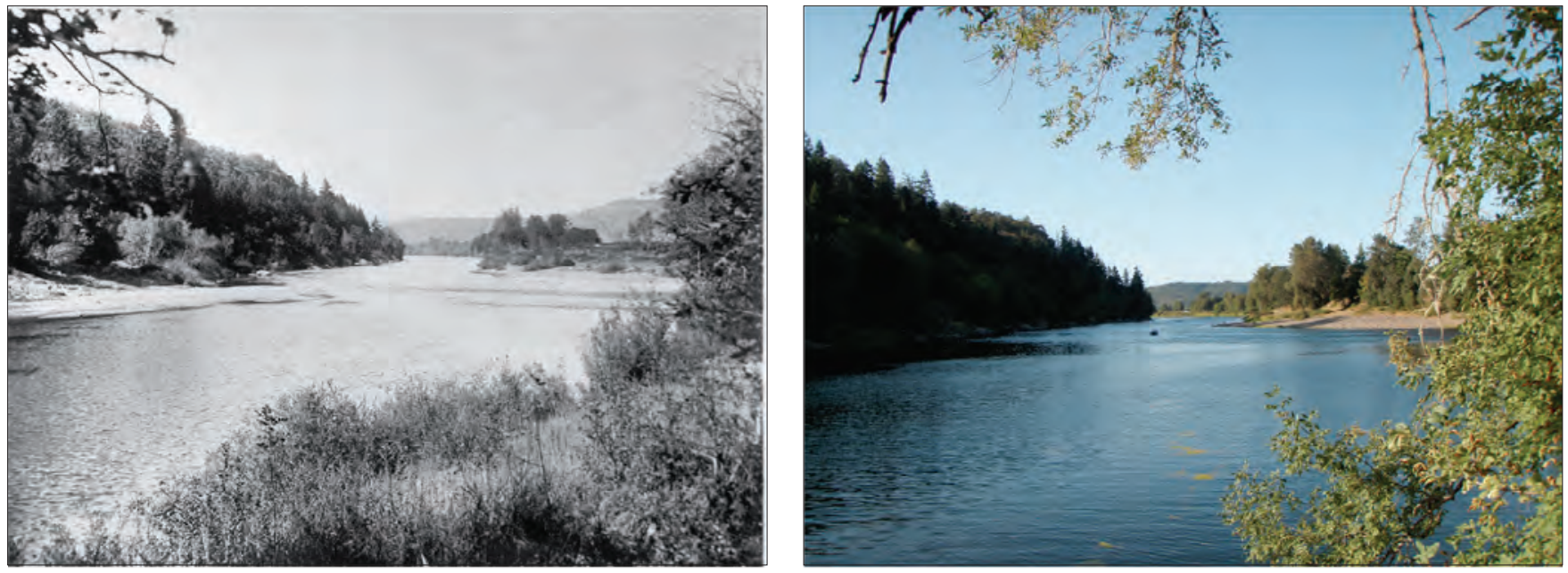

C. Booth Bridge, North Umpqua River, NUFPKM 10, 1925-2009
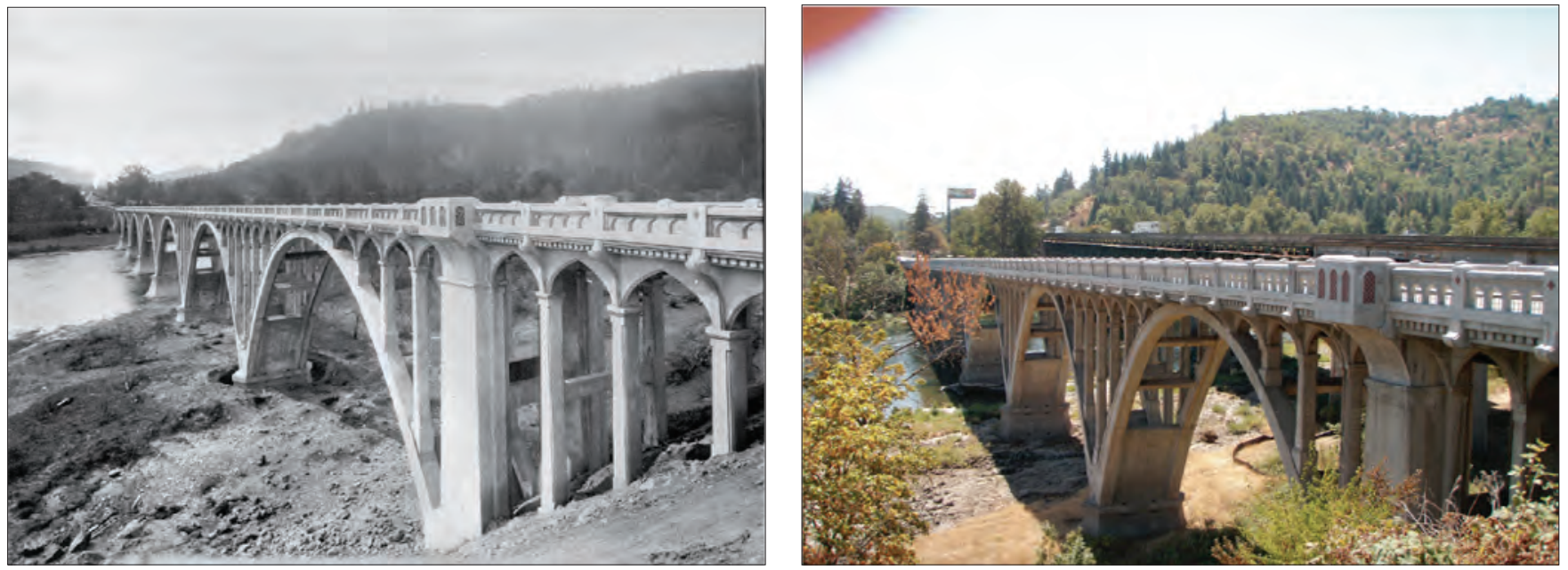

Figure 26. Historical channel changes in the Umpqua River basin, Oregon, 1920s-2009. Locations of photographs are provided in appendix A. 
A. Winston Bridge, South Umpqua River, FPKM 195, 1929-2009
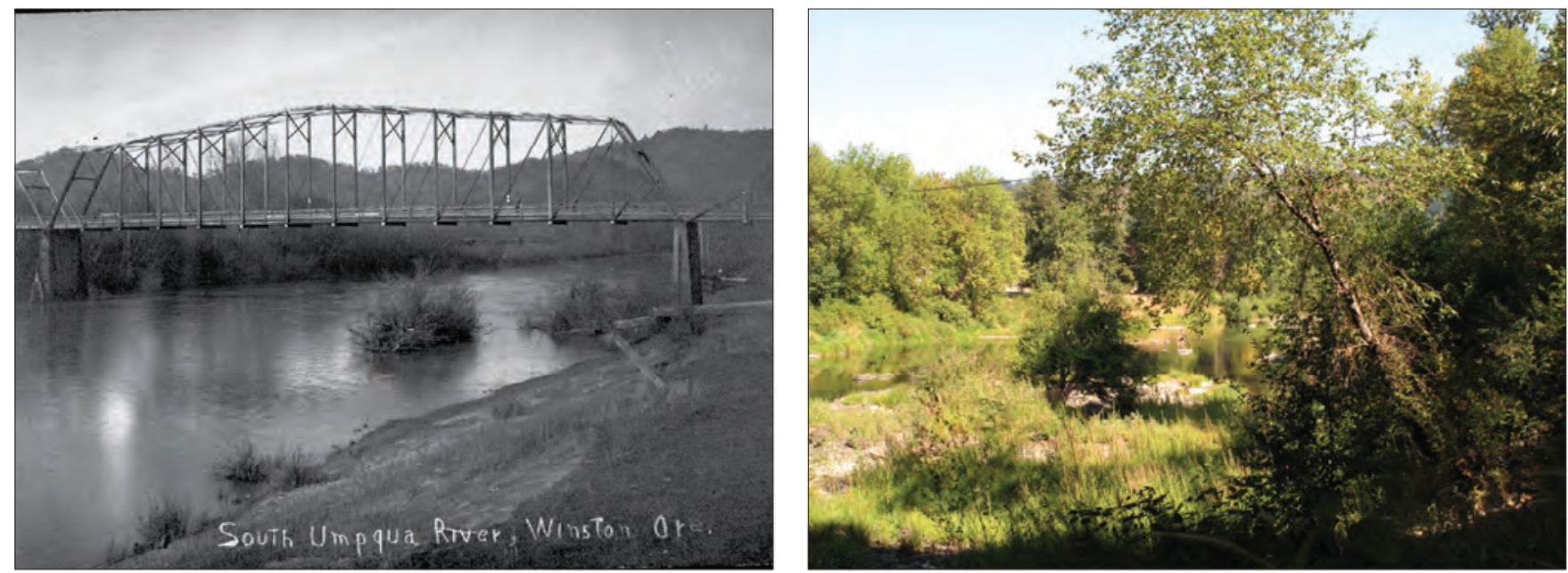

B. Rice Creek covered bridge, South Umpqua River, FPKM 204.5, early 1900s-2009
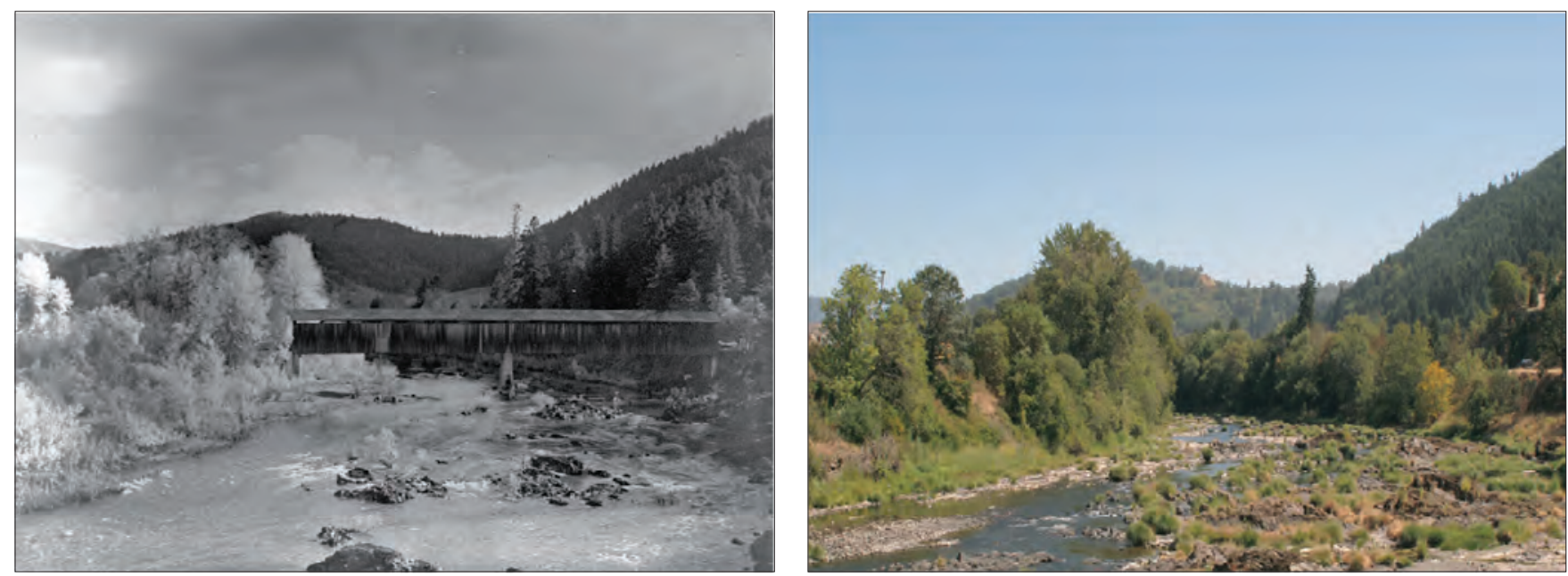

C. Whistler's Bend, North Umpqua River, NUFPKM 33, early 1900s-2009
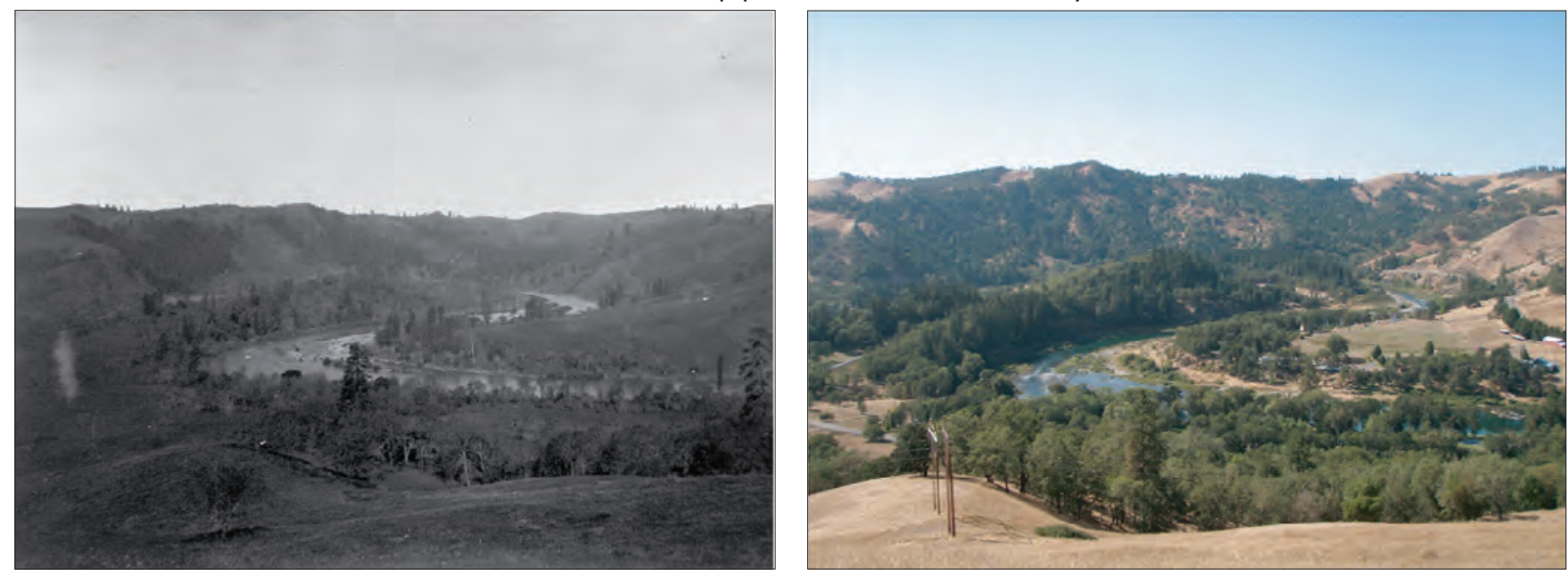

Figure 27. Historical changes in riparian vegetation in the Umpqua River basin, Oregon, 1920s-2009. Locations of photographs are provided in appendix A. 
Scanned, digital GLO surveys and notes were acquired from the Bureau of Land Management (2009) (table 7). Each map was georeferenced by matching section lines depicted on the maps with those from a recent PLSS coverage (Bureau of Land Management and U.S. Forest Service, 2009). Using meander surveys available for the Tidal, Coast Range, Garden Valley, North Umpqua reaches, as well as a part of the Roseburg reach, meandered bank lines were digitized to assess changes in planform. All bars depicted in the meandered and nonmeandered surveys were digitized to evaluate potential changes in bar size and position. Additionally, for each survey used in this study, the accompanying notes were reviewed, and key descriptions of channel characteristics were cataloged for comparison against more recent observations.

Comparison of the 1850s era GLO maps with the 1939 channel map reveals little detectable change in channel position along the meandered reaches. Although the 1850s channel commonly is depicted as wider than the 1939 channel, this is the likely consequence of the GLO mapping being conducted during high-flow winter months (Bureau of Land Management, 2009). Additionally, few gravel bars are depicted in the GLO maps unless they are islands (medial gravel bars) within the channel. This in part reflects GLO mapping protocols focusing on surveying bank lines separating flood-plain surfaces from water and active channel features such as bars and bedrock outcrops. Consequently, the GLO maps, because of the high flows at the time of the survey and the mapping protocols, do not provide an ideal source for comparison of gravel-bar area with more recent aerial photographs. For example, although GLO channel maps from 1853 to 1855 for the North Umpqua reach show no bars attached to flood plains, it is unlikely that attached bars were absent, as 22 medial bars were mapped in 1853-1855, resulting in specific bar area of $3.8 \mathrm{~m}^{2} / \mathrm{m}$ (fig. 28). In comparison, the specific area of medial bars was $5.9 \mathrm{~m}^{2} / \mathrm{m}$ in 1939 when the total bar area for this reach was $10.9 \mathrm{~m}^{2} / \mathrm{m}$ (figs. 16 and 28). Nevertheless, along much of the North Umpqua reach, medial bars shown by the 1853-55 maps are at or near the same places as those in the 1939 aerial photographs, although their size and shape have changed (fig. 28).

Meander survey notes accompanying the GLO maps describe bank height, bank composition, riparian vegetation, channel width, and bar characteristics along the channel. These historical observations generally match our channel mapping and field observations (appendix B). For example, on the North Umpqua reach, the banks were commonly described as "gravelly," especially where channel maps from 1939 onward show flood-plain-attached bars.

Very few bars were mapped in the Coast Range reach, with the notable exceptions of Myrtle Island (FPKM 126), a large, forested bar present in subsequent channel maps, and a large delta at the mouth of Elk Creek (FPKM 72), which was not present in later aerial photographs or maps.

Table 7. Map and survey data reviewed in the Umpqua River, Oregon, sediment-transport study.

[Abbreviations: FPKM, flood-plain kilometer; NUFPKM, North Umpqua flood-plain kilometer; LIDAR, Light Detection and Ranging]

\begin{tabular}{|c|c|c|c|c|}
\hline $\begin{array}{l}\text { Original source for } \\
\text { map or survey }\end{array}$ & $\begin{array}{l}\text { Type of map } \\
\text { or survey }\end{array}$ & Date(s) of survey & Coverage & Reference \\
\hline General Land Office & Township surveys & $\begin{array}{l}\text { 1853, 1855, 1857, 1858, } \\
\quad 1874\end{array}$ & $\begin{array}{l}\text { FPKM 0-169, } \\
\text { NUFPKM 0-45.5 }\end{array}$ & $\begin{array}{l}\text { Bureau of Land } \\
\text { Management, } 2009\end{array}$ \\
\hline $\begin{array}{l}\text { National Oceanic } \\
\text { and Atmospheric } \\
\text { Administration }\end{array}$ & Bathymetric surveys & 1886, 1920, 1971 & FPKM 0-15 & $\begin{array}{l}\text { National Oceanic } \\
\text { and Atmospheric } \\
\text { Administration, 2009a }\end{array}$ \\
\hline U.S. Geological Survey & Flood profiles & 1972, 1973 & FPKM 40-231 & Oster, 1972, 1973, 1975 \\
\hline U.S. Geological Survey & Digital elevation model & $\begin{array}{c}\text { Based on topographic } \\
\text { maps from various } \\
\text { dates 1957-1989 }\end{array}$ & Full coverage & $\begin{array}{l}\text { U.S. Geological Survey, } \\
\text { 2008; http://seamless. } \\
\text { usgs.gov/ }\end{array}$ \\
\hline
\end{tabular}



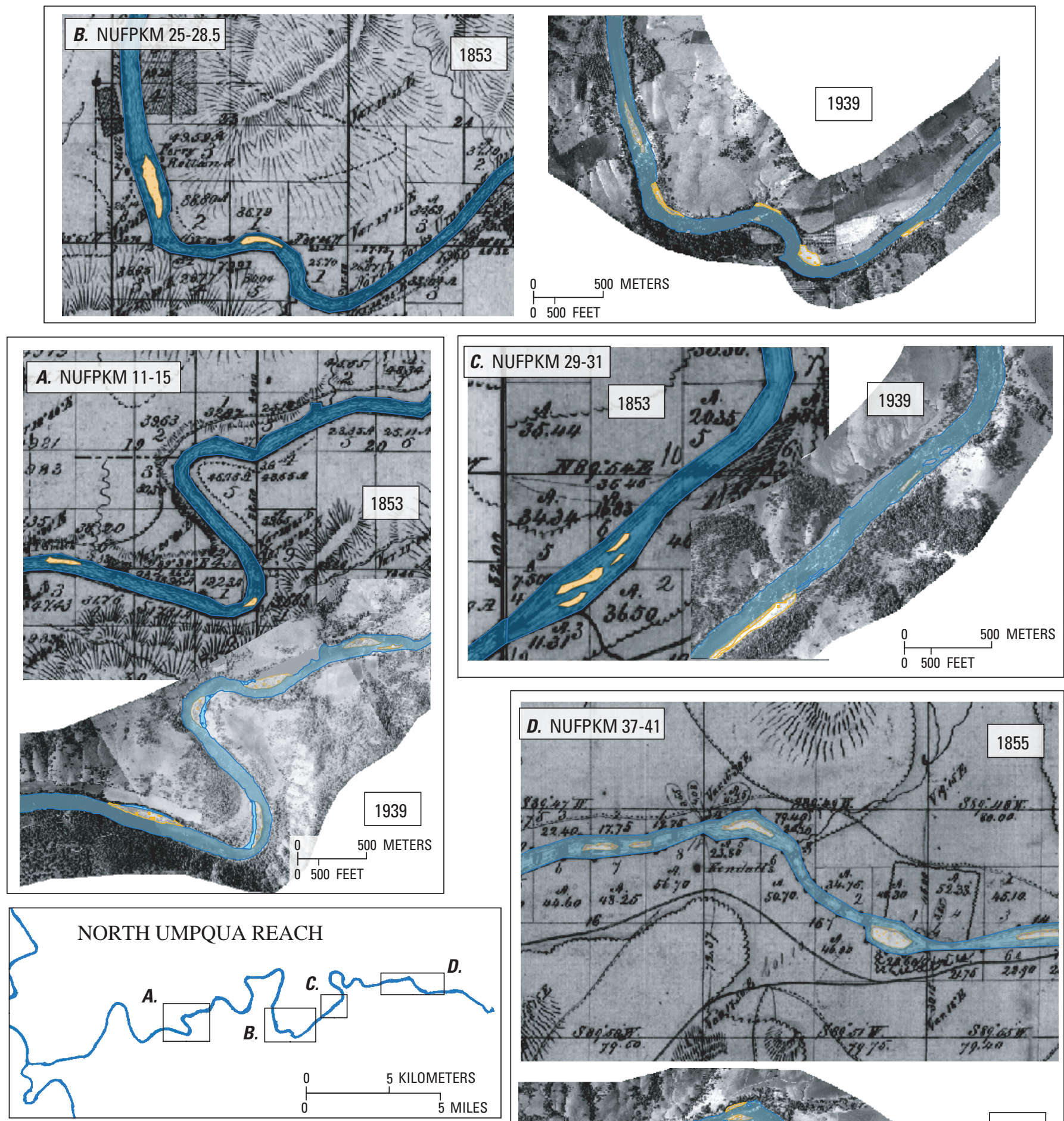

Base maps modified from U.S. Army Corps of Engineers

aerial photography and General Land Office maps.

UTM projection, Zone $10 \mathrm{~N}$

Horizontal datum: North American Datum of 1983

\section{EXPLANATION}
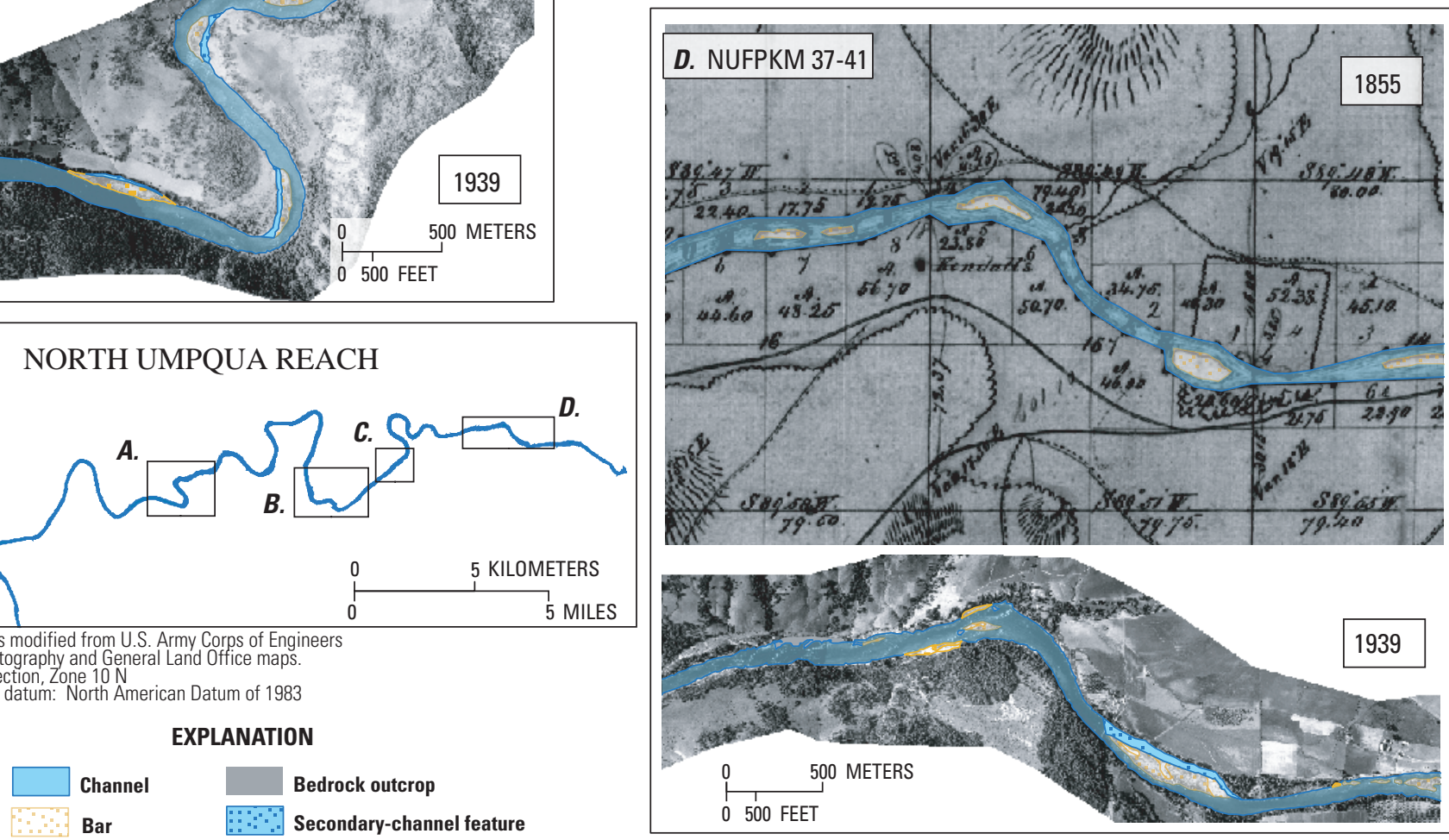

Figure 28. Comparison of channel position at selected sites along the North Umpqua reach as depicted in General Land Office surveys from 1853 to 1855 and channel maps based on aerial photographs from 1939. 
Although bars are not specifically mapped on the GLO maps of the Roseburg and Days Creek reaches, survey notes present at many of the major bars mapped from the 1939 aerial photographs indicate that these areas have been sites of gravel deposition since at least the mid-19th century. Near the location of Umpqua Sand and Gravel Bar (FPKM 171.4), the survey notes state that the bank is " $12 \mathrm{ft}$ high and brushy," which together with the GLO meandered bank lines indicates that the large, semistable bar vegetated with grasses and shrubs present in the 1939 aerial photographs was probably also present in the 1850s (fig. 22B). Similarly, at Little Valley Bar (FPKM 189.8), the 1853 survey notes describe a "low and sandy" bank, closely matching the aerial photographs from 1939 onward showing this area as a bare, low-elevation, active gravel bar. In addition, two prominent secondary channels on the Days Creek reach that are adjacent to large, active gravel bars are depicted GLO maps as "Dry Bed of River" (FPKMs 250-252), indicating these areas have likely been zones of dynamic gravel deposition for more than a century.

\section{Vertical Changes in Channel Morphology along Fluvial Reaches}

Although aerial photographs and historical maps show that channel planform along much of the Umpqua River study area has remained stable for over a century, we also assessed vertical changes in the position of the channel bed. Several survey sources were used to assess vertical changes to the longitudinal profile of the Umpqua and South Umpqua Rivers: (1) USGS Plan and Profile surveys completed in 1914 for parts of the Coast Range, Garden Valley, and Days Creek reaches (Marshall 1915; table 7), (2) thalweg elevation surveys conducted by the USGS for a series of flood studies encompassing all study reaches except for the Days Creek reach upstream of FPKM 240 (table 7; Oster, 1972; 1973), and (3) Light Detection and Ranging (LIDAR) topography acquired in 2009, for the Coast Range reach between FPKM 83 and 155 (table 7; Watershed Sciences, 2009). Additional detailed information on local changes to the channel bed was derived from repeat surveys of instream gravel mining sites and streamflow measurements from USGS streamflow-gaging stations located at Elkton (FPKM 84.7), Brockway (FPKM 195.3), and Winchester (NUFPKM 2.4) (fig. 1).

\section{Repeat Longitudinal Profile Surveys}

Some of the earliest surveys that extend above the head of tide and have broad spatial coverage were conducted by the USGS in 1914 to identify areas for hydropower development, and by the Corps of Engineers in the late 19th century to improve navigation between Reedsport and Roseburg. Because of their availability and extensive coverage, the USGS Plan and Profile surveys were used to document the historical longitudinal profile of the main stem Umpqua River along the Coast Range reach. These early surveys depict the outlines of riverbanks, islands, and rapids and include contoured elevation data for the water surface and banks, in

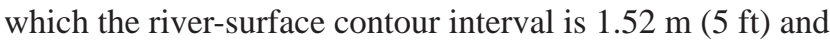

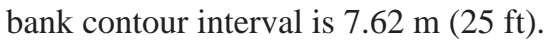

The USGS maps were scanned and georeferenced to the Bureau of Land Management and U.S. Forest Service (2009) Public Land Survey coverage using section corners and rectified using a first order polynomial transformation that yielded RMSE values of 10-13 m. Water-surface elevations, referenced to mean sea level, were digitized directly from the maps and converted to meters (NAVD 88 datum) by assuming that the vertical datum in the 1914 maps was approximately similar to the NGVD 1929 datum used in subsequent Plan and Profile maps from 1929. Because there has been little change in the overall channel position between 1914 and 2005, the river kilometer system based on the 2005 channel centerline was used directly to determine the appropriate linear distance for each water-surface elevation.

The most complete set of elevation data available for the study area was derived from channel surveys conducted by the USGS in support of flood studies in the early 1970s (Oster, 1972; 1973). These surveys extend from FPKM 0 to FPKM 240 and include channel thalweg elevations (NGVD 29 datum) at cross sections located approximately $300 \mathrm{~m}$ apart, referenced to an arbitrary linear system developed for the flood studies. The thalweg survey was aligned with the 2005 centerline reference frame by matching prominent landmarks and tributary junctions as noted in the 1970s surveys. Thalweg elevations were uniformly shifted by $2 \mathrm{~m}$ to approximate the adjustment to the NAVD 88 datum, which can range from 1.5 to $2 \mathrm{~m}$ for the western United States (Zilkoski and others, 1992). LIDAR topography acquired in 2009 (table 7), was available for a part of the Coast Range reach from FPKMs 83 to 155 and was used to extract water-surface elevations at 50-m increments along the 2005 centerline. Although the 1970s thalweg elevations extend as far upstream as FPKM 240, the 1914 Plan and Profile data extend only to FPKM 180 while the LIDAR data encompasses only FPKM 83-155. In total, the two profile surveys overlap for only the Coast Range, Garden Valley, and lowermost part of the Roseburg reaches, and all three datasets overlap for only the 72-km length of the LIDAR survey.

Comparison of longitudinal profiles from 1914, the 1970s, and 2009 along the Coast Range and Garden Valley reaches shows little variation over time (fig. 29). The mean difference between the 1914 and 2009 water-surface profiles is $-0.09 \pm 0.34 \mathrm{~m}$ for 45 locations where 1914 water-surface contours can be directly compared with the 2009 watersurface elevation from the LIDAR survey. Considering the many sources of error and uncertainty that arise when comparing historical longitudinal profile surveys, including uncertainties associated with matching the vertical datums, registration errors, and likely errors in the surveys themselves (more completely described by Magirl and others, 2005), this mean difference is probably not meaningful. The greatest discrepancy between the water-surface profiles occurs at a 
bedrock rapid downstream of Bullock Bridge (FPKM 119.3), where the 1914 water surface was $1 \mathrm{~m}$ higher than the 2009 water surface (fig. 29), which could possibly reflect channel modification due to historical navigation improvements.

Considering the close match between the historical and modern river profile data, the main conclusion from these comparisons is that there has been little systematic channel incision or aggradation, at least between FPKM 75 and FPKM 185 (encompassing the lower part of the Roseburg reach, and much of the Garden Valley and Coast Range reaches). This result is consistent with the extensive bedrock in the channel, which exerts overall control over the channel and watersurface profile.

\section{Specific Gage Analysis}

Following the approach of Klingeman (1973) and Smelser and Schmidt (1998), we conducted a specific gage analysis for three USGS streamflow-gaging stations (fig. 30): the main stem Umpqua River at Elkton (14321000), the South Umpqua River near Brockway (14312000), and the North Umpqua River at Winchester (14319500). The specific gage analysis allows detection of changes in streambed elevation by assessing changes in water elevation (stage) through time for a set of discharge values. At USGS streamflow-gaging stations, discharge is related to stage by a stage-discharge rating curve, which is based on coupled stage and discharge measurements taken at a range of streamflows. If channel conditions change substantially (as shown by consistent offsets of newer measurements from established rating curves), or if a station is moved, a new rating curve will be developed. The specific gage analysis evaluates trends in downstream hydraulic control as indicated by the sequence of rating curves; hydraulic control is, in turn, correlated to bed elevation. For situations where channel width and roughness remain stable (which aerial photographs indicate is the case for the three Umpqua River sites), the sequence of stages for a given discharge directly relates to changes in bed elevation.

Although the Umpqua River specific gage analysis is relatively straightforward due to the stability imposed by the bedrock channel, the gaging stations at each of the three analysis sites were moved at least once, requiring multiple datum shifts. Because the purpose of this task was to detect potentially small changes in bed elevation, we assessed changes in flow stage for low to moderate flows (14-283 $\left.\mathrm{m}^{3} / \mathrm{s}\right)$, which are more sensitive to minor adjustments in bed elevation and are less likely to be influenced by temporal changes in bank vegetation or changes in bank shape.

The specific gage analysis (fig. 30) shows that all three stations have had little change in stage associated with low flows over the period for which flow data are available. At the Umpqua River station near Elkton (fig. 30A), the gage location has changed four times over the period 1906-2008, with stages changing very little while at each location. For 1906-57, stage for each discharge varied by less than $0.12 \mathrm{~m}$, whereas during $1957-72$, stage at $14 \mathrm{~m}^{3} / \mathrm{s}$ decreased by approximately $0.2 \mathrm{~m}$. For 1972-2008, stage for all discharges changed less than $0.15 \mathrm{~m}$, indicating negligible change in bed elevation. The gage analysis for the North Umpqua River at Winchester spans 1924-30 and 1955-2008 (fig. 30C). For all discharges, and across both periods, measured stage changes are small, with the largest and most systematic being the decrease of 0.1 to $0.15 \mathrm{~m}$ associated with the 28 and $57 \mathrm{~m}^{3} / \mathrm{s}$ flow rating curves for 1955-2008. The South Umpqua River gaging station near Brockway provides data for 1906-12, 1924-28, and 1942-2008 (fig. 30B). For all three periods, the Brockway gage also shows only small changes in stage for the discharges used in this analysis. For 1942-2008, stage has lowered between 0.05 and $0.1 \mathrm{~m}$ for all discharges used in the analysis.

\section{Bar Evolution and Rates of Deposition at Mined Sites from Repeat Surveys}

Survey data for 2001-09 for six instream gravel-mining sites in the Roseburg and Days Creek reaches were used to calculate recruitment rates and to examine the evolution of individual bars as they responded to gravel extraction and various magnitude flood events. Although the South Umpqua River mining surveys reviewed in this study (table 8) do not account for all mining sites with either current or expired permits in the basin, these six sites are the ones with the most comprehensive survey records. All surveys used in this study were provided by the gravel operators and were conducted as a condition of permitted aggregate removal. During years of mining, the gravel bars generally were surveyed once in the midsummer prior to extraction to determine erosion or deposition during the previous winter, and then subsequent to mining (typically late summer or early fall) to document extraction volumes. From these surveys, the surveyors report "cut" and "fill" volumes in cubic yards. "Cut" volumes account for both erosion and extraction, although the survey notes and conditions generally provide interpretation of whether these volumes reflect deposit mining or erosion (IE Engineering, written commun., 2008; Joy Smith, Umpqua Sand and Gravel, written commun., 2010; Mike Flewelling, Knife River Inc., written commun., 2010). Volumes were converted to mass by assuming a bulk density of 2.1 metric tons $/ \mathrm{m}^{3}$ on the basis of data collected by Milhous (2001) as presented in Bunte and Abt (2001). 


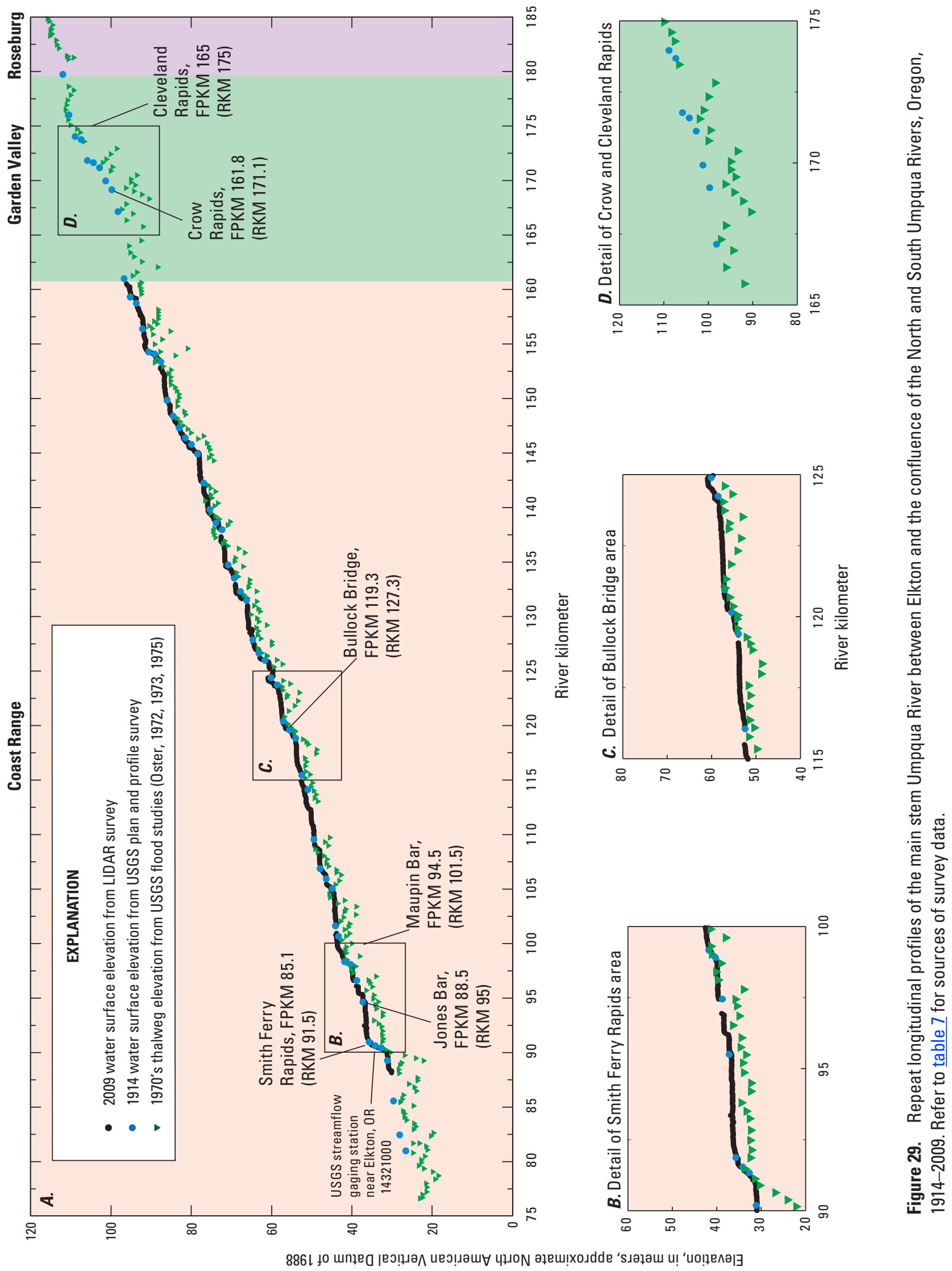




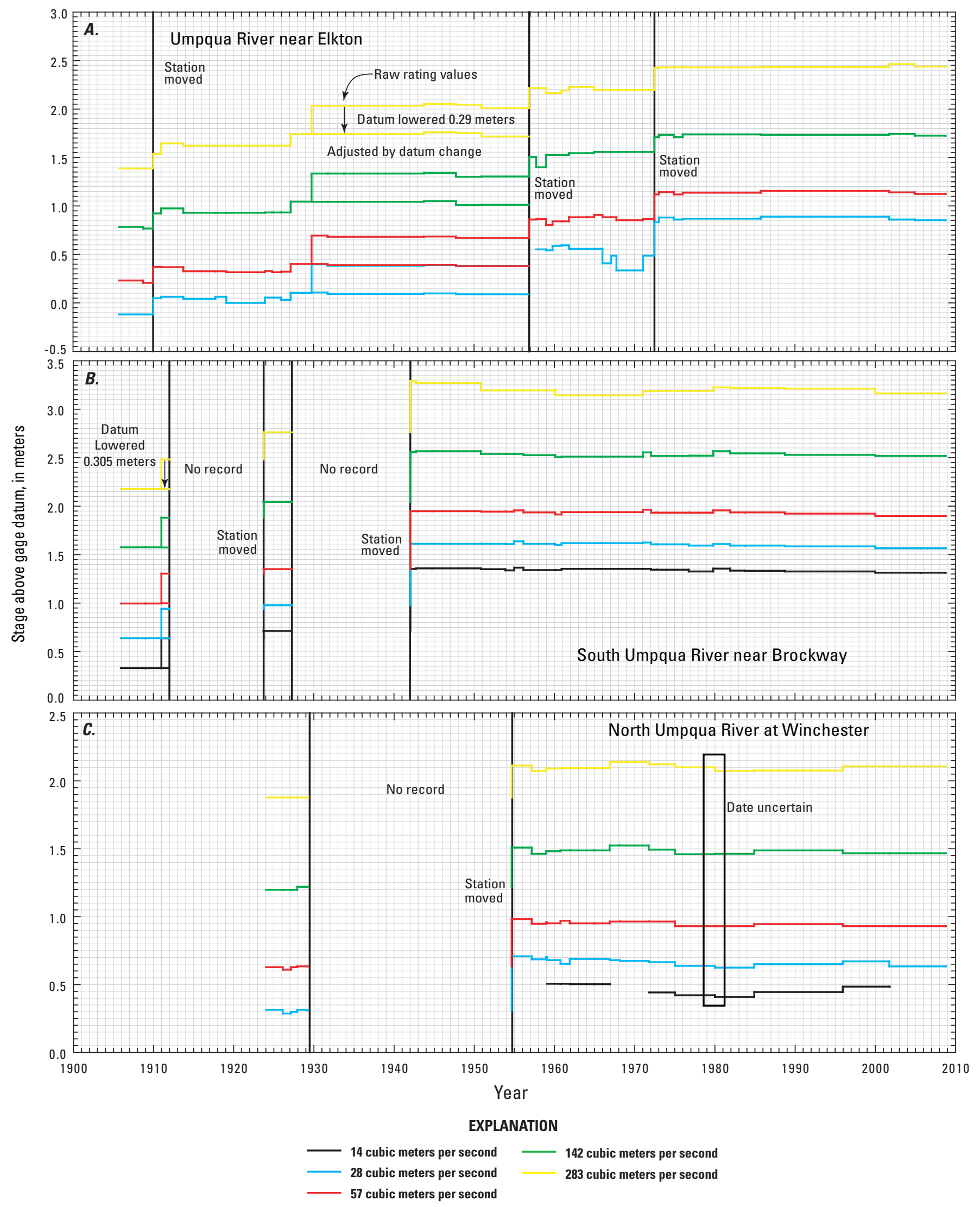

Figure 30. Stage-discharge rating-curve elevations for specific discharges for long-term main stem streamflow gages in the Umpqua River basin, Oregon. Source data is from station records housed at the Oregon Water Science Center, U.S. Geological Survey, Portland, Oregon. 
Pairs of surveys at three sites conducted from 2001 to 2004 report cut and fill volumes that include mining, erosion, and deposition, as well as the net change in bar volume. Annual surveys at the other three sites during 2001-04, and all sites during 2005-09, when there was no mining, provide only the net annual volumetric change. Because the surveys were conducted during the low-flow season, volumetric changes detected at each bar are assumed to have occurred during the previous high-flow season. For example, survey data from the summer of 2008 is used to judge bar growth occurring during WY 2008

Survey information for the six sites of historical gravel bar mining on the South Umpqua River show that mined volumes in 2001-04 for three actively mined sites (Umpqua Sand and Gravel Bar, Weigle Bar, and Days Creek Bar) ranged from 610 to 21,500 metric tons. The three other sites (Shady Bar, Little Valley Bar, and Gazley East Bar) had no mining during this period. These records and communication with individual operators indicate that none of the analyzed bars were mined after 2004. Since then, each of the six bars has accumulated gravel, with four of the six bars now showing positive balances relative to first available surveys (fig. 31).

Volumetric changes to the mined sites are most easily assessed for 2004-09, during which there was no mining and all topographic changes to the bars resulted from fluvial erosion and deposition. For this period, the deposition at individual bars ranged from 80 metric tons at Days Creek Bar during the low-flow year of 2004-05 to 30,600 metric tons at Shady Bar during the relatively high flows of 2005-06 (table 8). Losses due to erosion have ranged from 10,960 metric tons at the Umpqua Sand and Gravel Bar during the low-flow period of 2000-01 to 350 metric tons of erosion at Weigle Bar during 2003-04 (table 8). There can also be considerable variation between sites during a single year. For example, during the winter of 2004-05, Gazley East Bar (FPKM 232) lost 9,240 metric tons of gravel to erosion, while Little Valley Bar (FPKM 189.7) and Weigle Bar (FPKM 211) gained 2,610 and 2,450 metric tons of bed material, respectively (fig. 31; table 8).

Nearly all surveyed bars had volumes that substantially increased (aggrading as much as $0.5 \mathrm{~m}$ ) during the winter of 2005-06 in conjunction with high flows, including the December 31, 2005, peak of 2,164 m³/s, the highest peak flow on the South Umpqua River since December 1996 (fig. 31). Deposition volumes for individual bars for the winter of 2005-06 ranged from 8,370 metric tons at Weigle Bar to 30,600 metric tons at Shady Bar. During more typical water years such as 2007 (which had a peak flow of $1,302 \mathrm{~m}^{3} / \mathrm{s}$ on December 26, 2006, similar to the 2-year flood recurrence interval discharge at the nearby USGS streamflow-gaging station at Brockway), net changes ranged from 2,800 metric tons of erosion at Days Creek Bar (FPKM 249.9) to
9,750 metric tons of deposition at Shady Bar. The only bars that clearly have not regained the volume of sediment documented in the first survey are Days Creek Bar at FPKM 250 and Weigle Bar at FPKM 211, both of which had large amounts of gravel removed in 2004 (table 8).

The deposition volumes recorded by these surveys give a minimum indication of local bed-material flux rates for flow approaching the bar since the accumulated volume must have been transported from upstream. These volumes are minimum values because some bed material in transport undoubtedly bypassed each site and because the net changes detected by surveys do not completely distinguish the volume eroded from the bar surface from the total deposition volume. Nevertheless, these minimum flux values provide secure evidence of bed-material transport rates.

For example, the surveys at Shady Bar at FPKM 186.2 indicate minimum annual bed-material flux rates of 2,810 30,600 metric tons during WY 2002-08. Additionally, these bar surveys show that the bars primarily increase in size during high-flow years, and that low-flow years, such as 2005, result in either erosion or very little deposition. Although these repeat surveys provide constraints on site-specific bed-material flux rates and spatial and temporal patterns of bar erosion and deposition, the depositional volumes documented by surveys of mined bars cannot be extrapolated to estimate reach-scale depositional volumes for all bars because bar mining almost certainly creates depositional space, which enhances future deposition in comparison to unmodified bars.

\section{Planform and Bathymetric Changes in the Tidal Reach}

Channel and bar morphology in the Umpqua River estuary are substantially different from those in the fluvial reaches. Datasets unique to this reach provide the opportunity to track changes to channel planform and bathymetry over time, and enable assessment of the rate of bed-material replenishment relative to volumes dredged for aggregate as well as for navigation maintenance. Similar to the upstream fluvial reaches, changes to channel planform and bar area on the Tidal reach were evaluated using repeat mapping based on aerial photographs from 1939, 1967, and 2005, but the digitizing protocol and mapping scale were tailored specifically to the Tidal reach. Temporal variation in the bathymetry of the Umpqua River estuary was evaluated through comparison of repeat bathymetric surveys from 1886, 1920, and 1971. Additional information on channel morphology, processes, and sediment transport in the Tidal reach includes cross-section surveys and reports describing bathymetric changes in the area where commercial dredging historically occurred (FPKM 26-30.5) and GLO surveys dating to the 1850s. 
Table 8. Survey data for mined sites on the South Umpqua River, Oregon, 2001-2009.

[Survey data provided by the gravel operators. At most sites, surveys from 2001-04 provide raw cut and fill volumes, but for 2005-09, only the net volumes were provided. Survey volumes were converted to mass using a bulk density of 2. Abbreviation: FPKM, flood-plain kilometer; -, no data; na, not applicable]

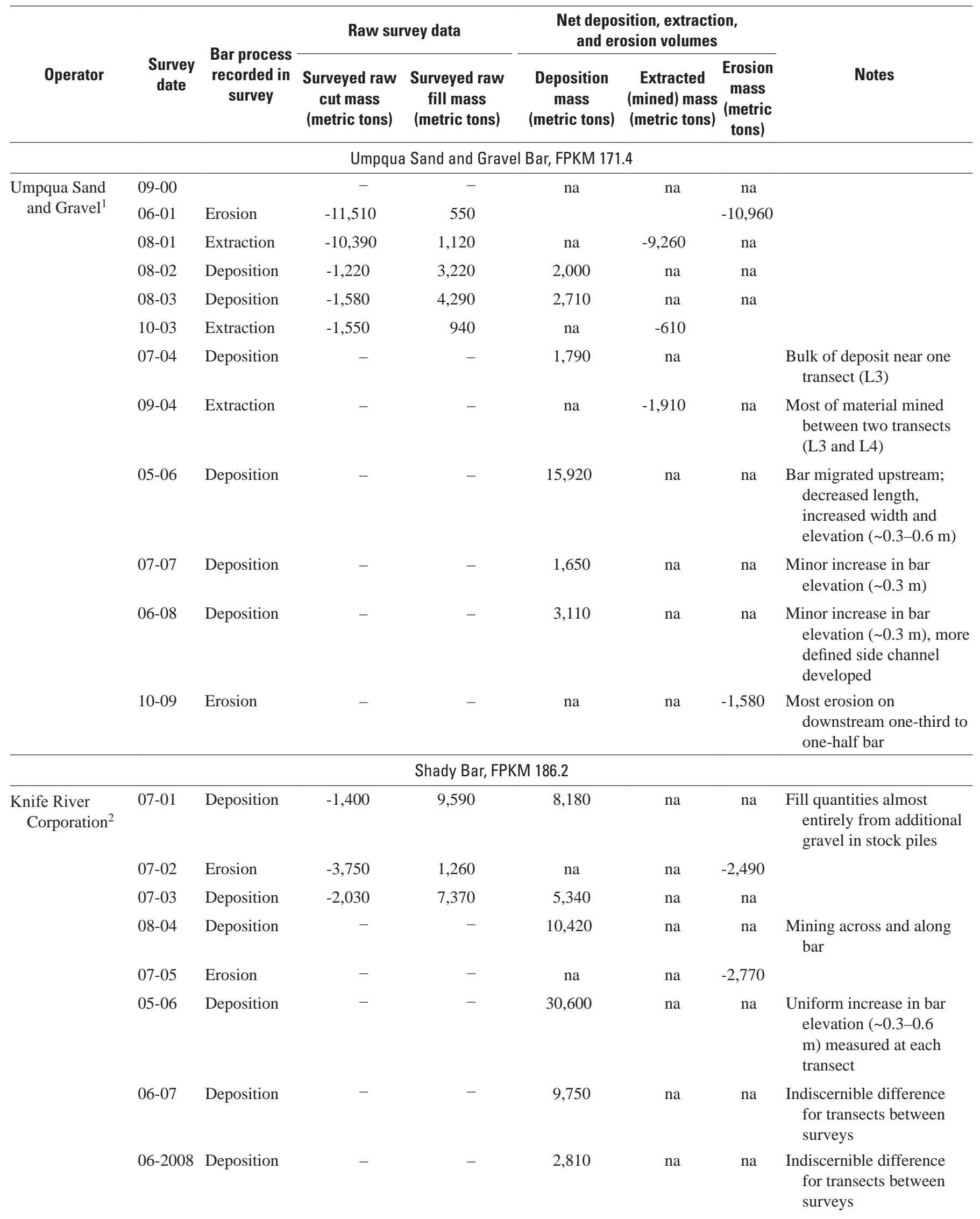


Table 8. Survey data for mined sites on South Umpqua River, Oregon, 2001-2009._Continued

[Survey data provided by the gravel operators. At most sites, surveys from 2001-04 provide raw cut and fill volumes, but for 2005-09, only the net volumes were provided. Survey volumes were converted to mass using a bulk density of 2. Abbreviation: FPKM, flood-plain kilometer; -, no data]

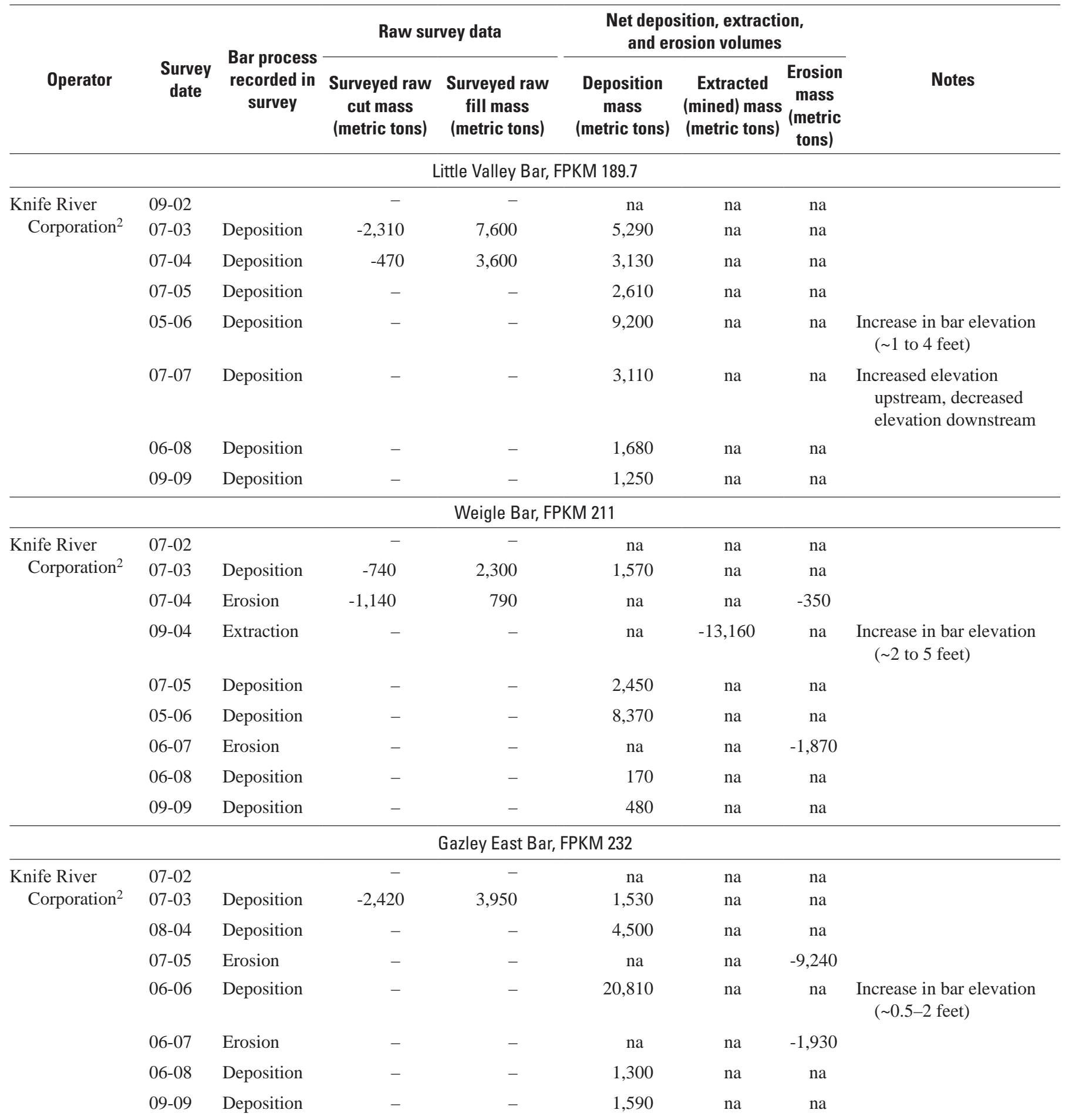


Table 8. Survey data for mined sites on South Umpqua River, Oregon, 2001-2009._Continued

[Survey data provided by the gravel operators. At most sites, surveys from 2001-04 provide raw cut and fill volumes, but for 2005-09, only the net volumes were provided. Survey volumes were converted to mass using a bulk density of 2. Abbreviation: FPKM, flood-plain kilometer; -, no data]

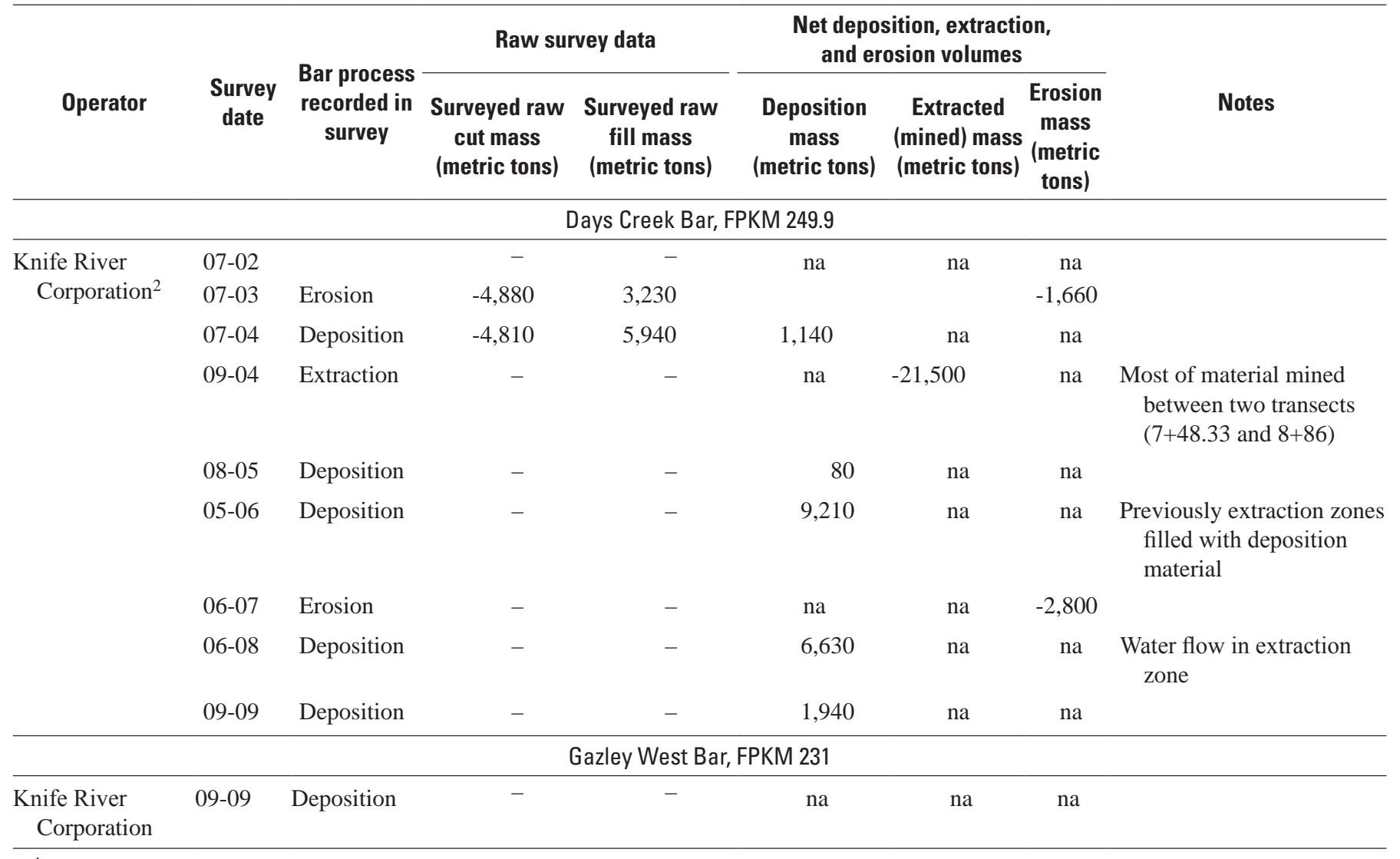

${ }^{1}$ Survey data provided by Joy Smith, Umpqua Sand and Gravel, written commun., 2008-10.

${ }^{2}$ Survey data provided by Mike Flewelling, Knife River Corporation, written commun., 2008-10 and IE Engineering, written commun., 2008 and 2009. 


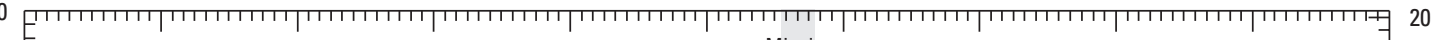

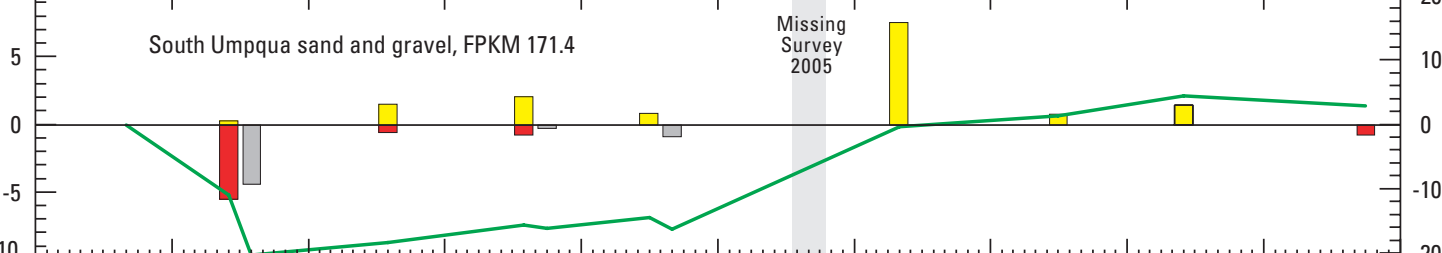

至

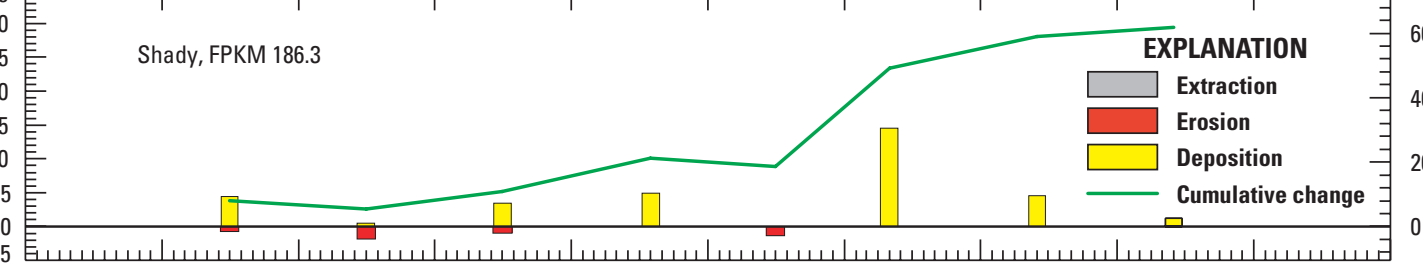

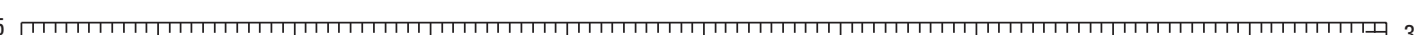

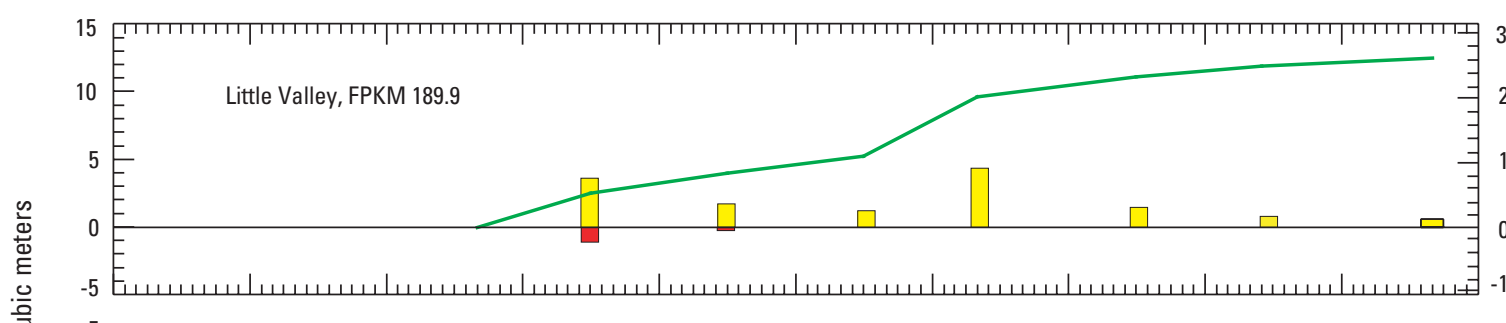

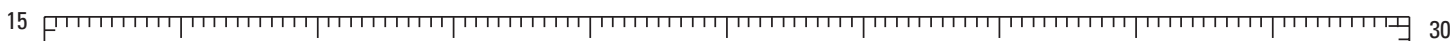

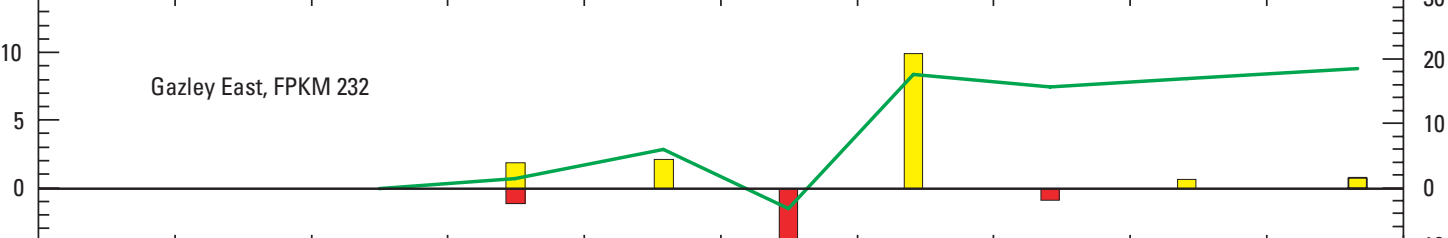

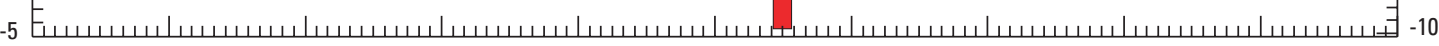
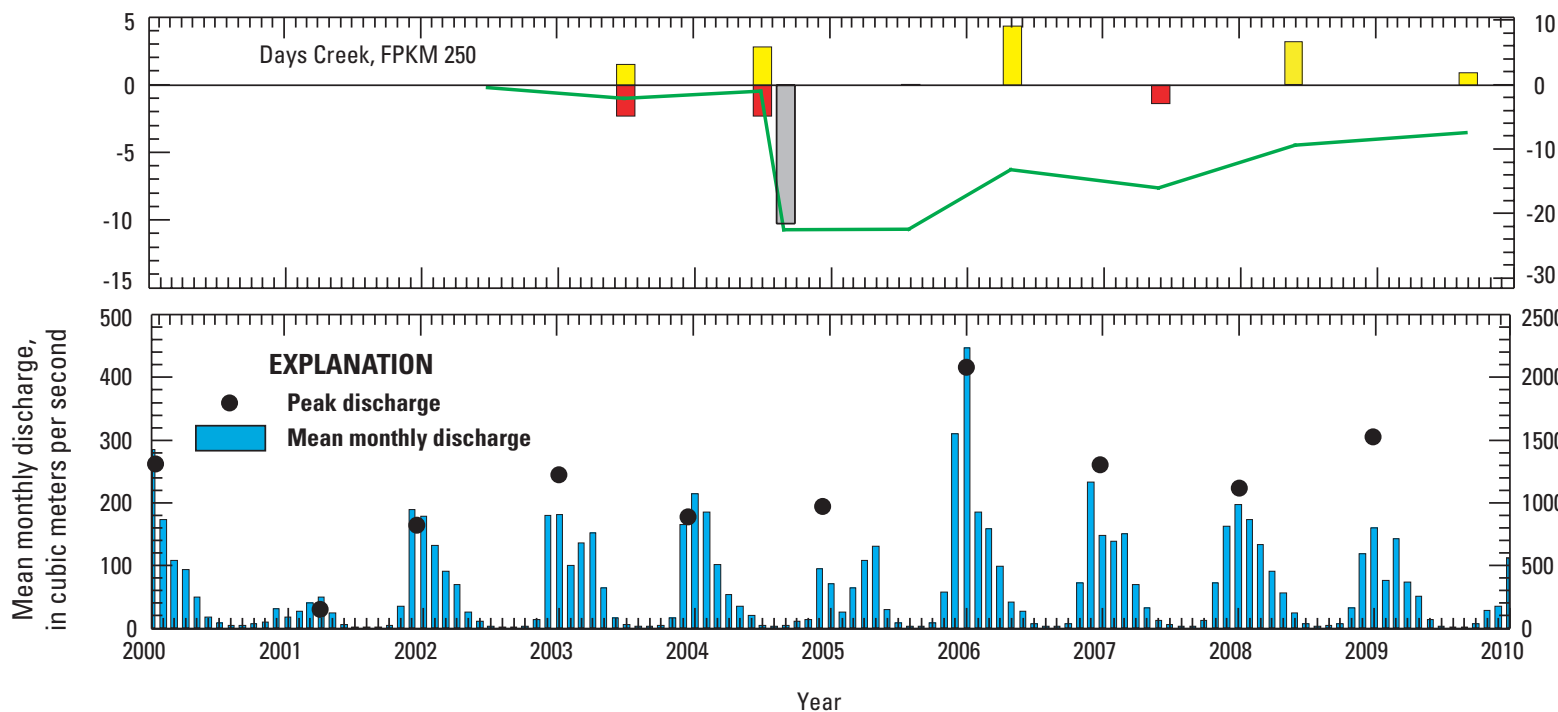

Figure 31. Gravel bar volume changes during 2001-09 at instream gravel mining sites along the South Umpqua River, Oregon. Refer to table 8 for data sources and values underlying this figure. For sites with missing surveys, cumulative totals assume no net change for the period of missing data. Mean monthly and annual (water year) peak flows are from the USGS data for streamflow-gaging station on South Umpqua River near Brockway (station 14312000). 


\section{Mapping of Tidal Reach from Aerial Photographs and General Land Office Surveys}

The overall process used to map channel and bar features in the Tidal reach from aerial photography is similar to that described previously for the fluvial reaches, with complete details on the aerial photograph acquisition, rectification, mosaicking, and digitizing methods provided with the geographic information system metadata (find at http:// www.geodata.gov). The three main differences between the approach used to map channel features on the Tidal reach and that used on the upstream fluvial reaches were: (1) mapping was conducted at a scale of 1:10,000 instead of 1:3,000 because of the much larger dimensions of channels and bars, (2) for the Tidal reach, the mapping unit "bar" refers to the broad, fine-grained sand bars and mudflats, whereas bars on upstream reaches are primarily gravel, and (3) vegetation cover on Tidal reach bars included riparian shrubs and grasses similar to that observed on upstream bars, but some of the low-elevation bars also had substantial algal cover.

Mapping in the Tidal reach also is influenced by the tide level at the time the aerial photographs were acquired. Tide levels in the Umpqua River estuary can vary by as much as $2.6 \mathrm{~m}$, but the mean range is approximately $1.6 \mathrm{~m}$ (on the basis of data from the National Oceanic and Atmospheric Administration [2009a]). Although tide level for the 1939, 1967, and 2005 photographs is unknown, the presence of expansive mudflats, which typically are inundated at high tide, indicates that most were acquired at low tide levels. Lastly, the aerial photographs from 1967 exclude the mouth of the river between FPKM 0 and 7. Therefore, although channel maps from 1939 and 2005 encompass the entire Tidal reach, the analysis of bar area, centerline length, and other metrics only include features from FPKM 7 to 40, where all three periods have complete photograph coverage.

Early maps and aerial photographs of the Tidal reach show that between Scottsburg (FPKM 40) and its confluence with Smith River (FPKM 15), the Umpqua River gradually widens from 143 to $500 \mathrm{~m}$ (as measured from 2005 aerial photographs) as the channel exits the Coast Range and approaches its mouth near Reedsport (FPKM 0) (fig. 6). Between Scottsburg and Brandy Bar (FPKM 27.5), there are only two small gravel bars, but between FPKM 15 and 27 there are 10 bars (fig. 6). These are predominantly forested islands with areas ranging between 30,000 and 50,000 $\mathrm{m}^{2}$. Near its confluence with the Smith River, the Umpqua River widens, creating a broad depositional complex of attached and medial bars including Bolon Island (FPKM 13) and Black's Island (FPKM 14) (fig. 6).
Channel mapping from 1939, 1967, and 2005 aerial photographs show that the overall character of the Tidal reach has remained similar, although individual bars have shifted. The role of navigation improvements also is apparent along the lower $5 \mathrm{~km}$ of the channel, where bank protection and jetties have imposed a stable channel planform. Between 1939 and 2005, there was a 21 percent net decrease in the area of mapped bars in the Tidal reach, but uncertainty due to differences in tide level and discharge in the underlying aerial photographs make it difficult to determine if differences in mapped bar areas reflect actual changes in sediment storage (fig. 32).

For example, between 1939 and 1967, mapped bar area decreased 32 percent, but the discharge in the 1967 photographs was nearly 8 times greater than that in the 1939 photographs, and the high flows likely obscured many low-elevation bars and biased the channel maps towards small measured bar areas (table 6; fig. 32). Discharge in the 2005 photographs is similar to that in the 1939 photographs, exposing many bars, including the large mudflats downstream of Smith River (fig. 6B) and increasing the total area of mapped bars by 17 percent between 1967 and 2005 (fig. 32). Although the low discharge biases the 2005 channel maps towards increased bar areas, some bars upstream of the Smith River confluence decreased in size during 1939-2005 (such as the medial bars near FPKM 15.8 as depicted in fig. 6B), which could partially explain the 21 percent net decrease in bar area from 1939 to 2005.

Comparison of the GLO maps from 1857 to 1858 with 20th century aerial photographs supports the general findings from the repeat channel mapping that channel planform along the Tidal reach has been substantially similar over the 148-year analysis period (fig. 33). However, comparison of the historical and modern maps also shows changes in bar vegetation attributable to development in the Umpqua River estuary. Notes accompanying the General Land Office surveys from 1858 describe Goose, Duck, and Black’s Islands (all situated near the mouth of Smith River) as "[composed of] sand, level marsh with heavy growth of grass” (appendix B), and although aerial photographs from 1939 depict possible grass and other herbaceous vegetation, the dominant vegetation in the 1967 and 2005 photographs is low, lightgreen vegetation that probably comprises mostly algae and rooted aquatic plants. Snelling's Island (opposite the mouth of Smith River) had "scattered timber" and "heavy grass" according to the 1858 survey notes, but was developed into an industrial area by 1939. Similarly, the southern part of Bolon Island was "hilly" in 1858, forested in the 1939 photographs, and then developed by the time of the 1967 photographs. 

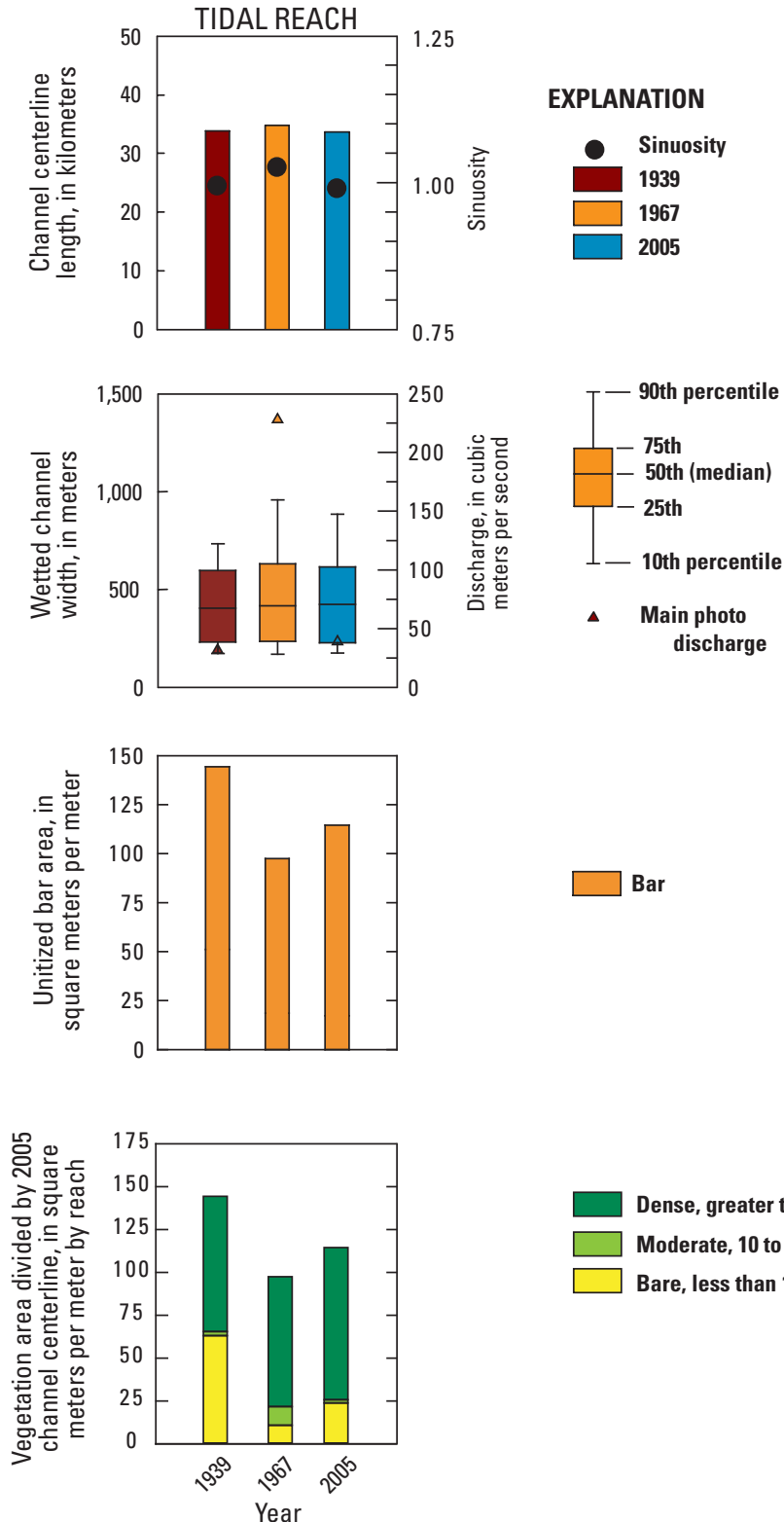

\section{Bathymetric Data Used in Study}

To characterize bathymetric changes to the Tidal reach, we compared three historical hydrographic surveys completed by the U.S. Coast and Geodetic Survey in 1886, 1920, and 1971 (National Oceanic and Atmospheric Administration, 2009b). These maps all show soundings spaced at 15- to 50-m intervals extending from the mouth of the Umpqua River to its confluence with the Smith River (FPKM 15). The 1971 elevation data were available as scanned sheets and digital elevation points. The scanned sheets have latitude and
Figure 32. Channel planform changes during 1939-2005 between FPKM 7 and 40 for the Tidal reach of the Umpqua River, Oregon. longitude lines corresponding to the North American Datum of 1927 (NAD 27) that were used to georeference the maps. The 1920 maps were registered to the georeferenced 1971 survey using survey points common to both maps and NAD 27 coordinates annotated to each map in the 1930s. The 1886 map was registered by matching its latitude and longitude lines to those of the 1920 map. The registered maps were rectified using a first order transformation. Soundings, elevation contours, and bank lines were digitized from the rectified maps. For 1971, soundings were already in digital format and therefore were not digitized as part of this study. 

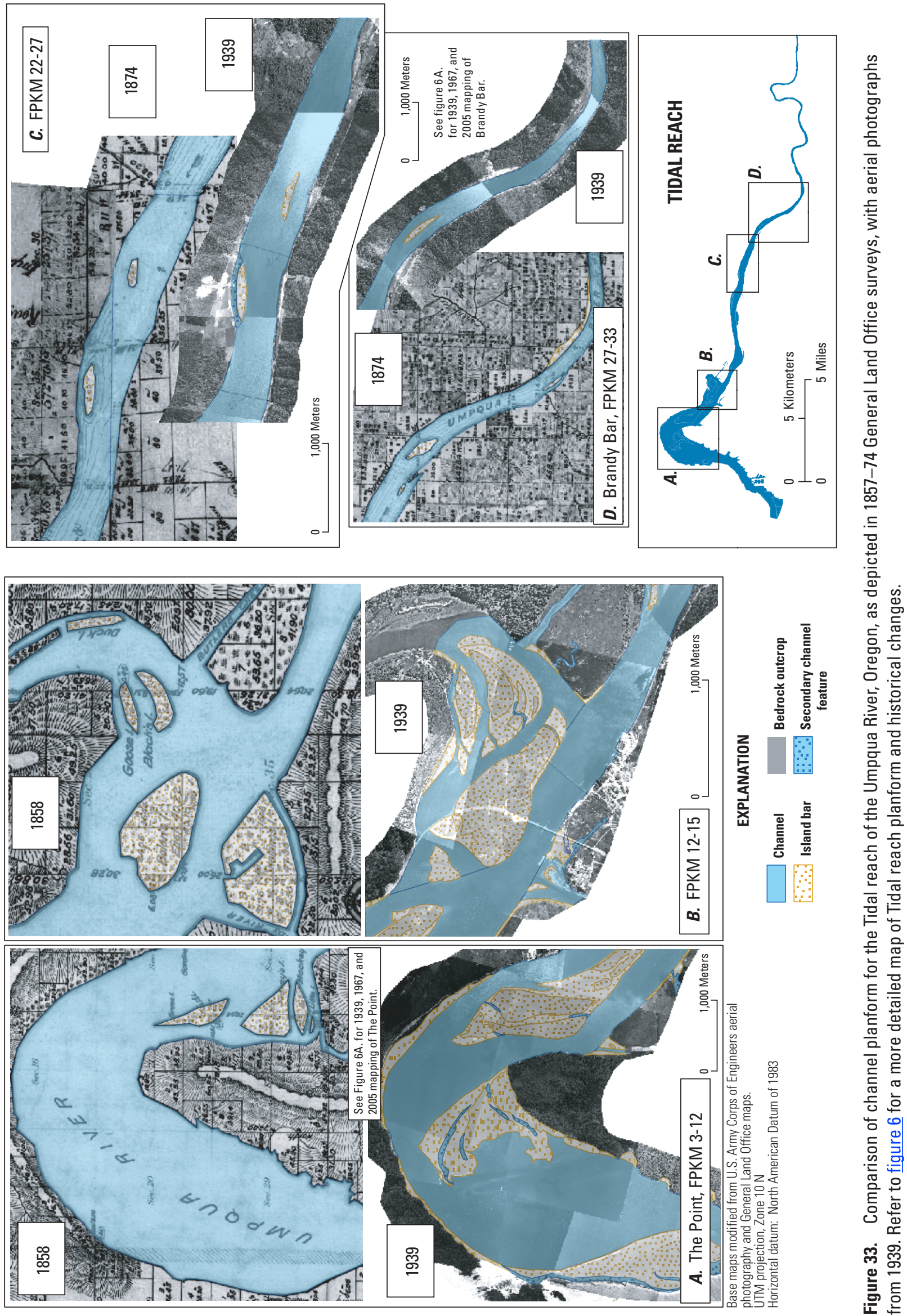
The elevation data in the original surveys were referenced to Mean Lower Low Water (MLLW), which we converted to NAVD 88 using VDatum (National Oceanic and Atmospheric Administration, 2009c). On the basis of National Oceanic and Atmospheric Administration (NOAA) charting procedures (Mark Frydrych, National Oceanic and Atmospheric Administration, written commun., December 2009), we assumed that changes in MLLW due to variation in tidal epochs were insignificant. The bank lines bounding the surveyed channel bed were assumed to have an elevation of $1.6 \mathrm{~m}$, which was the Mean Higher High Water elevation used by National Oceanic and Atmospheric Administration (2006) to derive a continuous surface from the 1971 survey. The final network of elevation points and contour lines were used to develop Triangulated Irregular Network (TIN) surfaces of the bathymetry from each period, which were converted to raster format with the TIN to Raster tool in 3D Analyst Toolbox using linear interpolation (fig. 34). Cross sections were then extracted at key locations from the gridded three-dimensional surfaces to evaluate changes to channel geometry over time (fig. 35).

Another set of survey data available for the Tidal reach includes cross sections from FPKM 26-30.5 near the site historically dredged by LTM, Inc. These data were obtained by LTM, Inc. and were provided by Lidstone and Associates (written commun., 2008). In addition, a report by CH2M Hill (1971) furnishes soundings of the commercially dredged areas from 1970.

\section{Uncertainty and Limitations with Repeat Survey Data}

The total uncertainty regarding the bathymetric surfaces created from the survey data of 1886, 1920, and 1971 is a function of the original data and the processing involved with creating digital maps and interpolated surfaces of the bathymetries. Although the accuracy of the maps from 1886 and 1920 is unknown, the process by which the original maps were registered, rectified, and digitized may have introduced horizontal uncertainty on the order of $\pm 15.5 \mathrm{~m}$ (based on distances between benchmarks digitized from the surveys versus the corresponding NOAA published benchmark location), but in most places the horizontal uncertainty is much lower, with average values ranging from 1.8 to $4.2 \mathrm{~m}$. The 1971 bathymetric data published by NOAA are described as having horizontal accuracy of $3 \mathrm{~m}$ and vertical accuracy of $1 \mathrm{~m}$ for depths greater than $20 \mathrm{~m}$ and of $0.2 \mathrm{~m}$ for depths less than $20 \mathrm{~m}$ (National Oceanic and Atmospheric Administration, 2006).

\section{Results of Repeat Surveys}

Inspection of the repeat bathymetric data indicates that the Tidal reach is dynamic, with areas of deepening and aggradation, but the overall trend for most time sequences is thalweg deepening. Repeat bathymetric surveys for the lower estuary (FPKM 0-15) shows that thalweg deepening is most prominent downstream of Winchester Bay (FPKM 1) where navigational dredging has resulted in more than $10 \mathrm{~m}$ of bed lowering. Substantial deepening is also evident upstream to FPKM 7, where the 1971 thalweg is more than $5 \mathrm{~m}$ deeper than the channel bed in 1886 (figs. 34 and 35), although other areas show little net change (figs. 35E and 35F). The large bar complexes, including Steamboat, Bolon, and Black's Islands, have migrated and changed in extent between 1886 and 1971 (fig. 34) in conjunction with deepening of the thalweg adjacent to these bars (for example, cross section C in fig. 35).

Examination of cross sections and reports documenting bathymetric change in the reach historically dredged for aggregate (FPKM 26-30.5) shows considerable variability between cross sections, with some areas becoming shallower over time, whereas other areas show up to $1.4 \mathrm{~m}$ of deepening. The overall trend evident in the repeat cross sections supplied by LTM Inc. was that dredged areas were not substantially replenished in subsequent surveys. The repeat bathymetric surveys for the 1971 CH2M Hill analysis showed that excavations in areas not mined for more than 5 years had not been refilled. Based on these limited data, we infer that the supply of bed material entering the Tidal reach is less than the 136,380 $\mathrm{m}^{3}$ average annual rate of commercial dredging (based on extraction volumes from 1949 to 2002 as presented in CH2M Hill [1971] and by Lidstone and Associates, written commun. [2009]).

\section{Summary of Channel Morphology and Historical Channel Change}

Within the fluvial reaches, the North Umpqua, South Umpqua, and main stem Umpqua Rivers are a mixed alluvial and bedrock river system with an active channel composed of bedrock and gravel alluvium. Most of the mapped gravel within these reaches is stored in large bars (greater than 20,000 $\mathrm{m}^{2}$ ) deposited within large amplitude river and valley bends. Although widely spaced, these large bars account for nearly 60 percent of the total gravel area within the study area (as mapped from aerial photographs from 2005). More numerous gravel "patches" typically are small (less than 2,000 $\mathrm{m}^{2}$ ) and thin veneers of gravel overlaying and adjacent to bedrock outcrops, particularly at rapids and channel bends (fig. 16). 


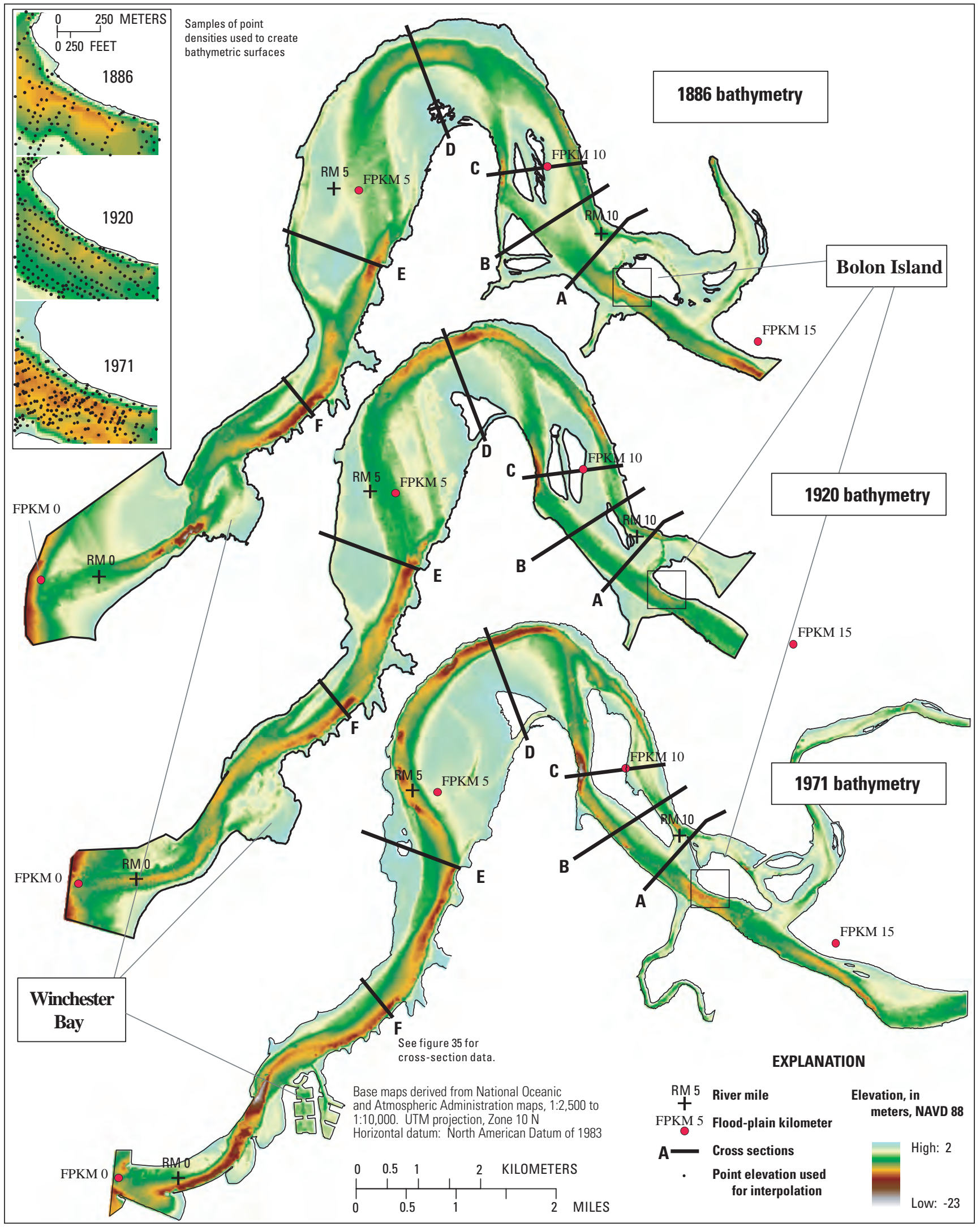

Figure 34. Bathymetric changes to the Tidal reach of the Umpqua River, Oregon, as detected in historical navigation surveys from 1886, 1920, and 1971. Refer to table 7 for information on survey sources. 

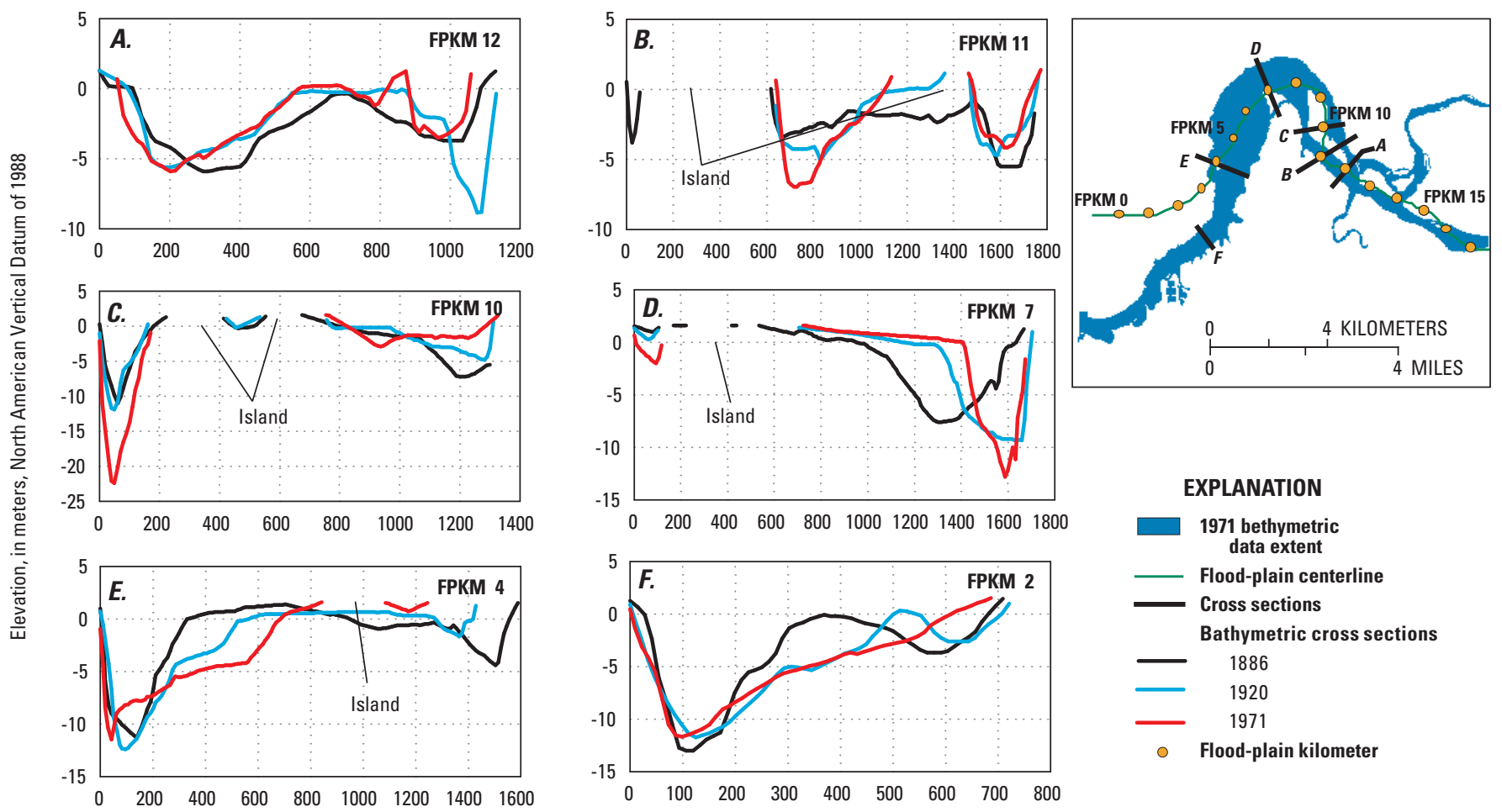

Flood-plain kilometer

Station, in meters, arbitrary datum

Figure 35. Cross sections from navigational surveys dating to 1886, 1920, and 1971. Cross sections were extracted from bathymetric surfaces created from historical surveys that were rectified and digitized in this study. Cross section locations are shown in figure 34. 
Throughout the 70-year period of available aerial photographs, gravel has been most abundant along the Days Creek and Roseburg reaches where specific bar area was 17.6 and $13.6 \mathrm{~m}^{2} / \mathrm{m}$ in 2005 (respectively), but, locally, the channel in these reaches flows on bedrock. In contrast, the channels of Coast Range and North Umpqua reaches are dominated by bedrock outcrops and have much lower specific bar areas of 5.1 and $6.7 \mathrm{~m}^{2} / \mathrm{m}$ in 2005. The Garden Valley reach also has more exposed bedrock than gravel bars, as this short (20-km long) transitional reach between the Coast Range reach and the confluence of the North and South Umpqua Rivers had only 12 gravel bars in 2005 and a specific bar area of $5 \mathrm{~m}^{2} / \mathrm{m}$. The relative abundance of gravel along the Roseburg and Days Creek reaches is consistent with relatively large contributions from the Klamath Mountains terrain.

The abundant in-channel bedrock and generally close flanking valley walls of the fluvial reaches restrict channel movement, and there are no reaches of extensive lateral channel migration and consequent bar growth. The Roseburg reach has the greatest sinuosity and its planform is likely the most mobile of all fluvial study reaches, but historical channel change primarily has occurred during major floods when minor shifts in local channel position can be accommodated by corresponding changes in adjacent gravel bars (fig. 9C). The general stability and bedrock character of the fluvial reaches is consistent with historical maps and descriptions noting channel position and substrate character as far back as the 1820s. There is no evidence of substantial incision along the fluvial reaches, probably due to the widespread occurrence of bedrock in the channel. The specific gage analysis, however, indicates local channel lowering of approximately $0.1-0.2 \mathrm{~m}$, which is probably reflective of bedrock incision.

For most fluvial reaches, total bar area has decreased over the period of historical aerial photograph analysis, although this assessment is confounded by different discharges associated with the photographs and by bar growth evident for most reaches in the 1967 photographs, probably resulting from the 1964 flood. Overall, the total area of mapped gravel in the fluvial reaches decreased 29 percent between 1939 and 2005, but decreases in bar area and associated increase in active-channel bedrock is most evident for the Roseburg, Days Creek, and North Umpqua reaches. The 59-percent decrease in gravel bar area and 115-percent increase in bedrock area since 1967 on the North Umpqua reach is probably, at least in part, due to the 1952-55 construction of hydropower dams upstream of the study reach, which trap bed material from 32 percent of the North Umpqua basin. Long-term variation in climate probably also has contributed to decreases in bar area, as peak flows have declined since the 1950s on the lower North Umpqua River, South Umpqua River, and several tributaries (table 2), which may have contributed to vegetation encroachment on bars and decreased gravel transport.

Historical increases in bar area resulted primarily from scouring and fresh deposition on flood-plain surfaces (especially in 1967) and by bar growth into areas formerly inundated by the low-flow channel. Bar erosion primarily has resulted from lateral channel shifting, which trims lowelevation margins of bars and is the main style of channel change during low-flow years. Nearly all study reaches had substantial increases in bar area between 1939 and 1967 resulting from the December 1964 flood, but smaller increases in bar area associated with a series of floods during the winter of 1996-97 are evident in photographs from 1995 to 2000. Overall patterns of bar growth and erosion detected from repeat mapping from aerial photographs are consistent with repeat bar surveys for sites of historical gravel mining in the Days Creek and Roseburg reaches. These surveys, dating from 2001 to 2009, indicate that bars increase in size during high-flow years, and that local bed-material flux rates may exceed 30,000 metric tons/yr for some locations and years.

The Umpqua River in the Tidal reach has a much lower gradient, resulting in large and expansive flanking bars composed primarily of sand and mud, in contrast to the smaller gravel-rich bars in the fluvial reaches. This reach is a drowned Holocene valley for which basinwide sediment delivery has not been sufficient to construct a graded profile to the Pacific Ocean. Historical changes to channel planform in the Tidal reach have predominantly been the shifting boundaries of the large bar complexes near the mouth of Smith River. Additionally, navigational improvements farther downstream and jetty construction at the entrance to the Umpqua River have stabilized the channel planform. Differences in tide level and discharge at the time the aerial photographs were acquired make it difficult to discern historical trends in bar area in the Tidal reach. Repeat bathymetric surveys from 1886, 1920, and 1971 indicate thalweg incision, probably resulting from dredging for aggregate as well as channel deepening for navigation. In some locations, the thalweg in the Tidal reach was more than $10 \mathrm{~m}$ deeper in 1971 than in 1886. 


\section{Bed-Material Characterization and Transport}

\section{Bed-Material Characterization and Source}

Three primary objectives motivated sampling of bed material throughout the Umpqua River study area. First, a detailed dataset of grain-size distributions collected at closely spaced intervals throughout the study area provides a foundation for evaluating longitudinal trends in transport capacity (for example, Wallick and others, 2010). Secondly, collection of particle-size data from both the surface and subsurface of gravel bars enables calculation of armoring ratios, which can be used to assess the spatial patterns in sediment supply relative to transport rates (Dietrich and others, 1989; Bunte and Abt, 2001). Third, spatial patterns in clast lithology can be used to assess bed-material contributions from tributary basins (Wallick and others, 2010).

\section{Gravel Distribution and Textures}

Throughout most of the study area, the Umpqua River above the head of tide, along with the North Umpqua and South Umpqua Rivers, flows directly on bedrock alternating with boulder-cobble substrates. Locally flanking the channel are gravel bars, commonly small, thin, and discontinuous above and adjacent to bedrock outcrops. Some bars, however, are large, with areas that exceed 120,000 $\mathrm{m}^{2}$ and thicknesses of possibly several meters. As mapped from 2005 aerial photography, the total area of roughly 336 gravel bars (minimum mappable area $300 \mathrm{~m}^{2}$ ) along the main stem Umpqua and South Umpqua Rivers between the head of tide (FPKM 40) and Tiller (FPKM 273.1) was approximately $2.7 \mathrm{~km}^{2}$ (fig. 21), accounting for only 10.5 percent of the total active channel area and covering much less area than the $19 \mathrm{~km}^{2}$ of low-flow channel area.

Positions of most bars are fixed by valley physiography and bedrock outcrops, but although their locations are constant over time, aerial photographs show that bar texture and overall appearance can change in response to flow conditions. Bar height above the low-water surface, as determined from field observations and LIDAR topography (which covers part of the Coast Range reach), ranges from below the low-flow water surface on the low-elevation bars to more than $1 \mathrm{~m}$ on the high surfaces of stable bars.

\section{Sampling}

Bed-material textures on gravel bars along the Umpqua River system were measured by sampling 51 bars throughout the study area in August 2009. Of these, 27 were on the South Umpqua River, 5 on the North Umpqua River, 14 on the main stem Umpqua River, and 5 on other tributaries (table 9). Along the main stem Umpqua and South Umpqua Rivers between Scottsburg (FPKM 40) and Tiller (FPKM 273.1), the average distance between sampling sites was $6.5 \mathrm{~km}$. The distance between sample sites was greater, reaching intervals of as much as $20 \mathrm{~km}$, along the lower reaches where bars are sparse. Sampling sites were selected on the basis of bar size, accessibility, and their ability to represent reach-scale conditions. All five sample sites on the North Umpqua River were located upstream of Winchester Dam (FPKM 180.9), as no substantial gravel deposits were found downstream of the dam. Sites on three major tributaries (Calapooya, Myrtle, and Cow Creeks) also were sampled to characterize bed-material sediment entering the Umpqua River system.

Surface-particle sizes at each of the sampling sites were measured by a modified grid technique (Kondolf and others, 2003). At each site, 200 particles were measured at 0.3-m increments along two parallel $30-\mathrm{m}$ tapes using an aluminum template (Federal Interagency Sediment Project US SAH-97 Gravelometer). The tapes were spaced 1-2 $\mathrm{m}$ apart and were aligned parallel to the long axis of the bar (fig. 36).

Although most sampling was conducted at bar apices to enable consistent comparisons, bedrock outcrops, vegetation, and irregular bar topography resulted in some bars not having a clearly defined apex (which we defined as the topographic high point along the upstream end of the bar). In such instances, a section of the bar that appeared active and representative of the overall bar was measured. Few of the bars, however, had uniform surface textures; many either had irregular patches of different-sized clasts, varying amounts of exposed bedrock and vegetation, or had been disturbed by vehicle traffic. Hence, some variation among bars can be attributed to local depositional conditions and post-deposition disturbance.

Bed-material substrate was sampled at 30 of the 51 surface-material sites to evaluate textural differences between the surface and subsurface material (a measure of "armoring”) and to support sediment transport calculations. The samples were collected by removing the surface layer to a depth approximately equal to the maximum grain size, and then collecting approximately $40 \mathrm{~L}$ of sediment from an area approximately $30-50 \mathrm{~cm}$ in diameter and $30-50 \mathrm{~cm}$ in depth (fig. 36). The bed-material substrate was analyzed by the USGS Sediment Laboratory in Vancouver, Washington, where the samples were dried and sieved into half-phi intervals. Total sample weights ranged from 53 to $83 \mathrm{~kg}$, with an average sample weight of $69 \mathrm{~kg}$. At many sites, the sample weight did not quite meet the criteria suggested by Church and others (1987), although 22 of the 27 samples had sample weights that were at least 50 percent of the recommended weight. These same 22 samples were judged to have medium accuracy (whereby the largest particle represented no more than 1 percent of the total sample mass). 


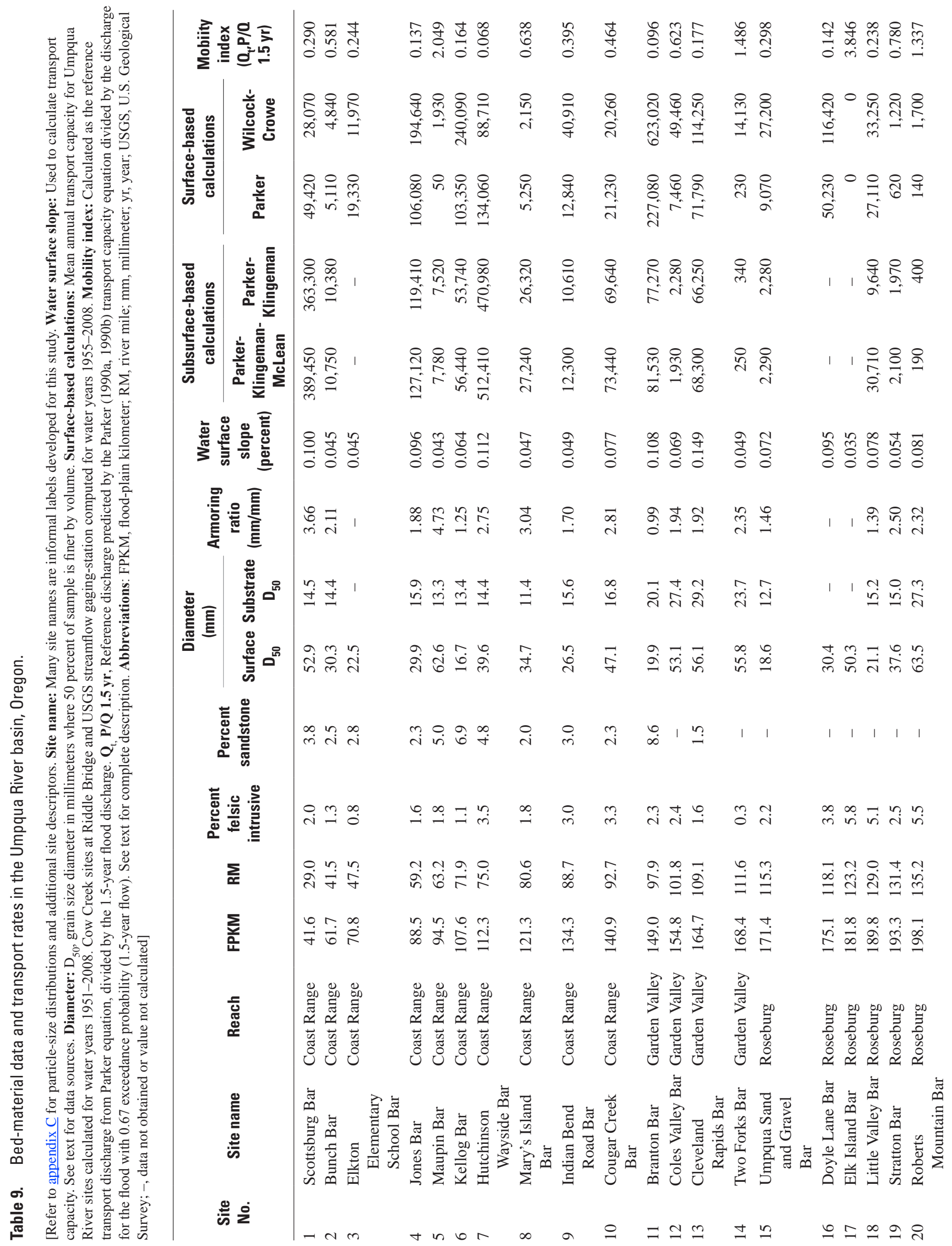




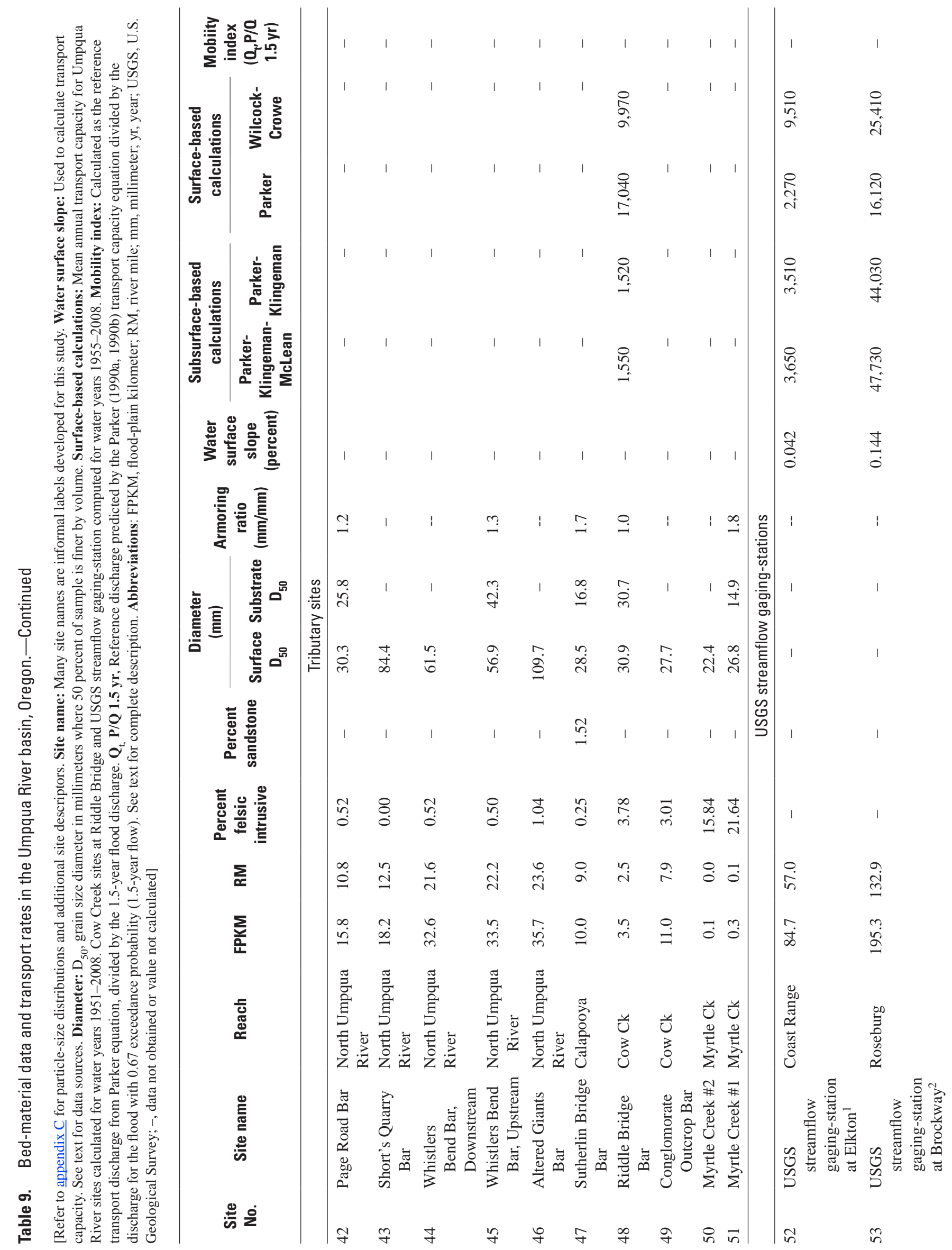




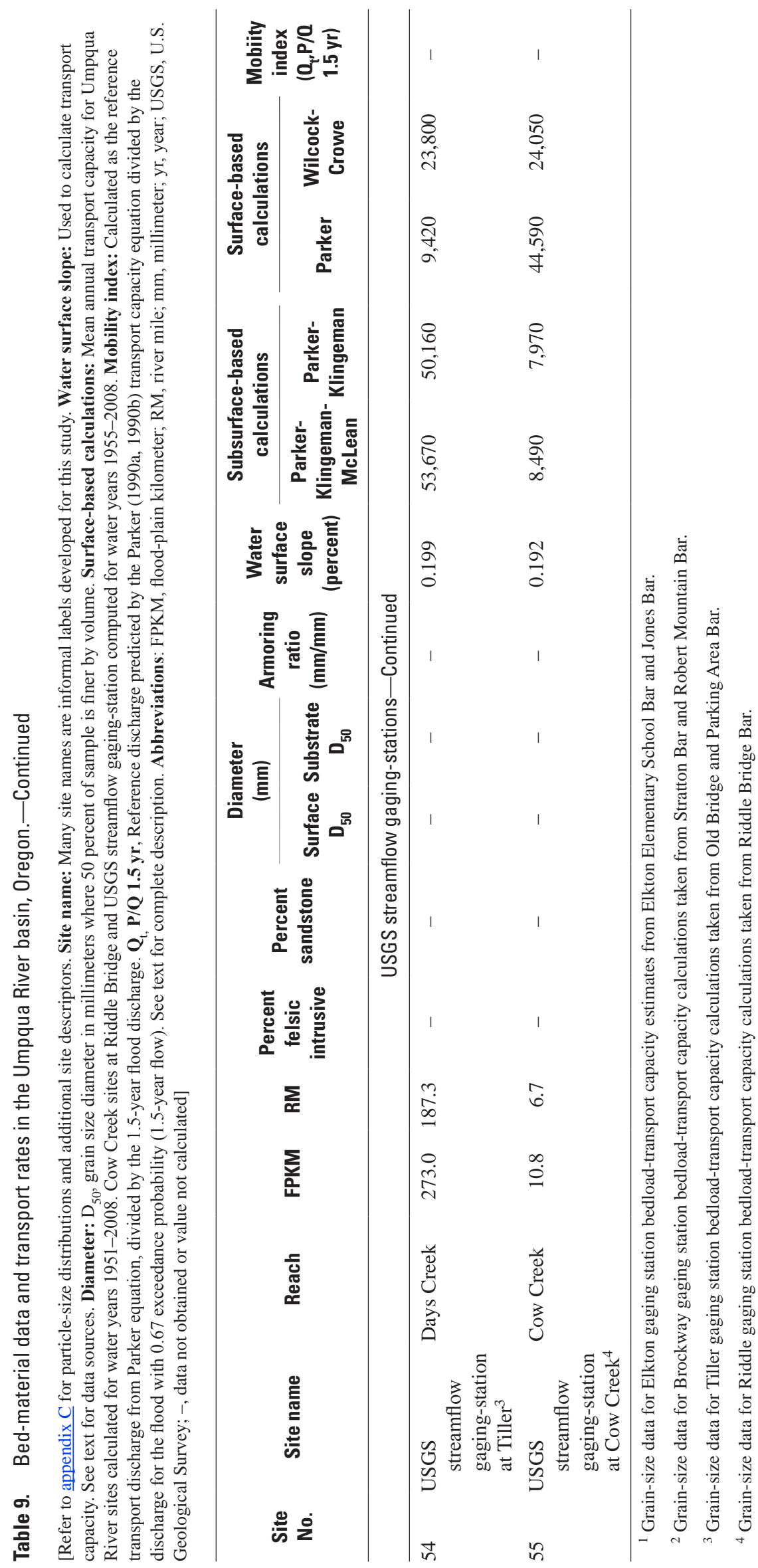



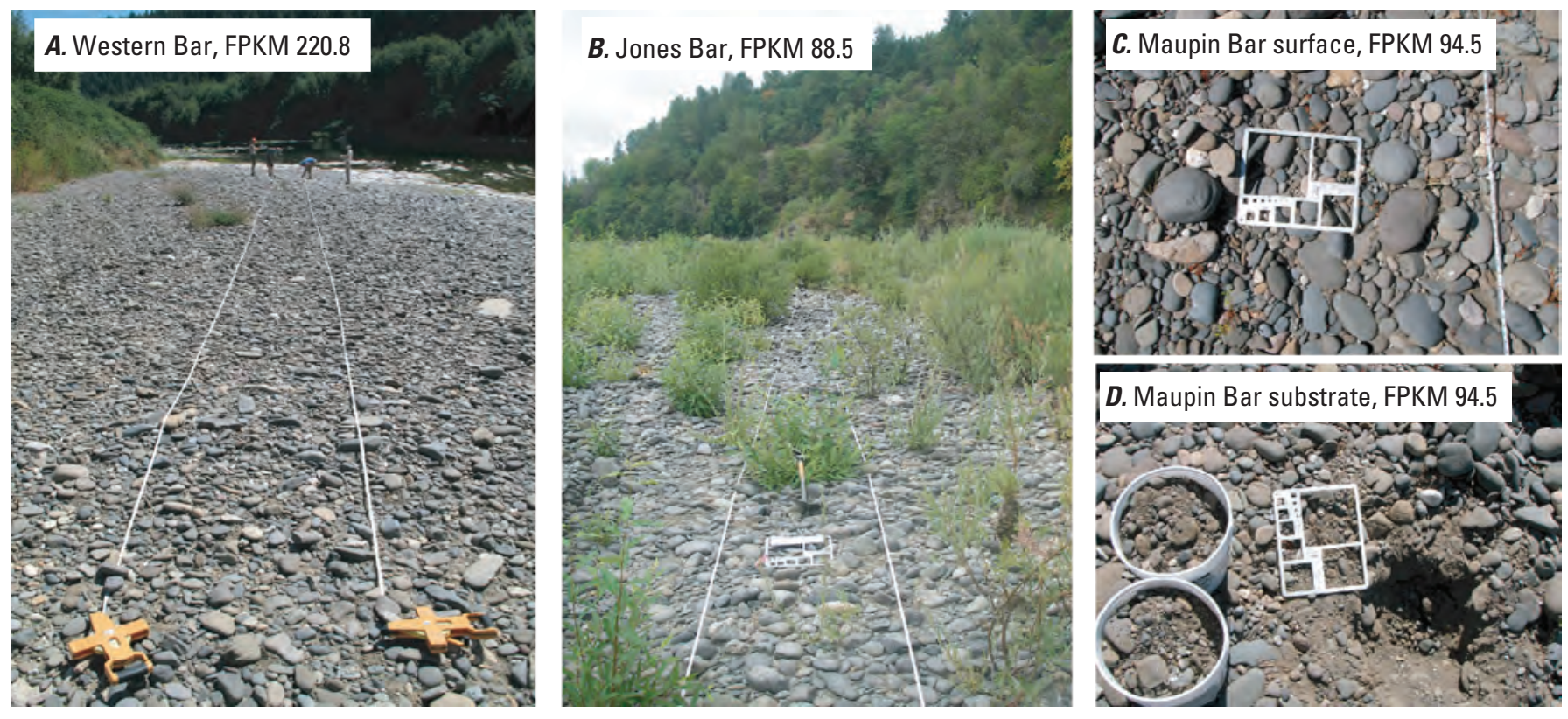

Figure 36. Examples of bed-material sampling sites in the Umpqua River basin, Oregon.

\section{Assessment of Bed-Material Sizes}

For the surface samples of the Umpqua and South Umpqua Rivers, the median particle diameter $\left(D_{50}\right)$ ranged in size from 16 to $122 \mathrm{~mm}$ (fig. 37; table 9). As for most rivers, median bed-material particle size diminishes downstream. The coarsest samples were measured along the Days Creek reach between FPKM 240 and FPKM 268, where the channel flows through a series of large, alternating bars downstream of the confluence of Coffee Creek. Variability is greatest within the Days Creek and Roseburg reaches, where surface material median grain-size diameter $\left(\mathrm{D}_{50}\right)$ can differ by more than $30 \mathrm{~mm}$ between bars spaced 2-3 km in distance (fig. 37; appendix C). This heterogeneity in surface textures reflects the wide ranging differences in the size and character of gravel bars along the Umpqua River system, as adjacent sampling sites varied considerably with respect to local hydraulic conditions, gravel thickness, abundance of bedrock, and degree of vegetation.

The subsurface samples were considerably finer and had less spatial variability than the surface-material samples measured at the same locations (fig. 37; appendix C).

Subsurface $D_{50}\left(D_{50 s}\right)$ increased along the Days Creek reach, decreased sharply from 35 to $10 \mathrm{~mm}$ at the confluence of Cow Creek (FPKM 232), then remained nearly constant along the Roseburg reach until coarsening to about $35 \mathrm{~mm}$ at the confluence with the North Umpqua River. Downstream of the confluence of the North Umpqua and South Umpqua Rivers, $\mathrm{D}_{50 \mathrm{~s}}$ was relatively constant at about $20 \mathrm{~mm}$ for more than $100 \mathrm{~km}$ as the Umpqua River traverses the Coast Range.
Particle-size distributions show that although the coarsest fractions of the subsurface and surface samples were similar in size, the bed-material subsurface was dominated by a finer matrix of sand to pebble-sized particles (ranging in size from 1 to $10 \mathrm{~mm}$ ), whereas the bar surfaces were dominated by cobble-sized clasts greater than $30 \mathrm{~mm}$ (table 9; appendix C). Disparity between surface and subsurface particle size is commonly attributed to an imbalance between sediment supply and transport capacity, with the surface layer coarsening when the transport capacity of the fine fraction exceeds its supply (Dietrich and others, 1989; Buffington and Montgomery, 1999).

Hence, the ratio of $\mathrm{D}_{50}$ to $\mathrm{D}_{50 \mathrm{~s}}$ (or the "armoring ratio") can be used to infer the balance between sediment availability and transport capacity. Armoring ratios close to 1, indicating similar surface and subsurface sediment median grain size, indicate high sediment supply, whereas channels with excess transport capacity typically have armoring ratios closer to 2 (Bunte and Abt, 2001). Along the Umpqua and South Umpqua Rivers, armoring ratios ranged from approximately 1 to 4.7, but more than half of the measured bars had armoring ratios greater than 2, indicating excess available shear stress and transport capacity relative to bed-material supply (fig. 37; table 9). The mean armoring ratio for the 25 measurement sites on the South Umpqua and Umpqua Rivers was 2.3, slightly higher than the 2.0 value measured for three sites on the Chetco River (Wallick and others, 2010). 


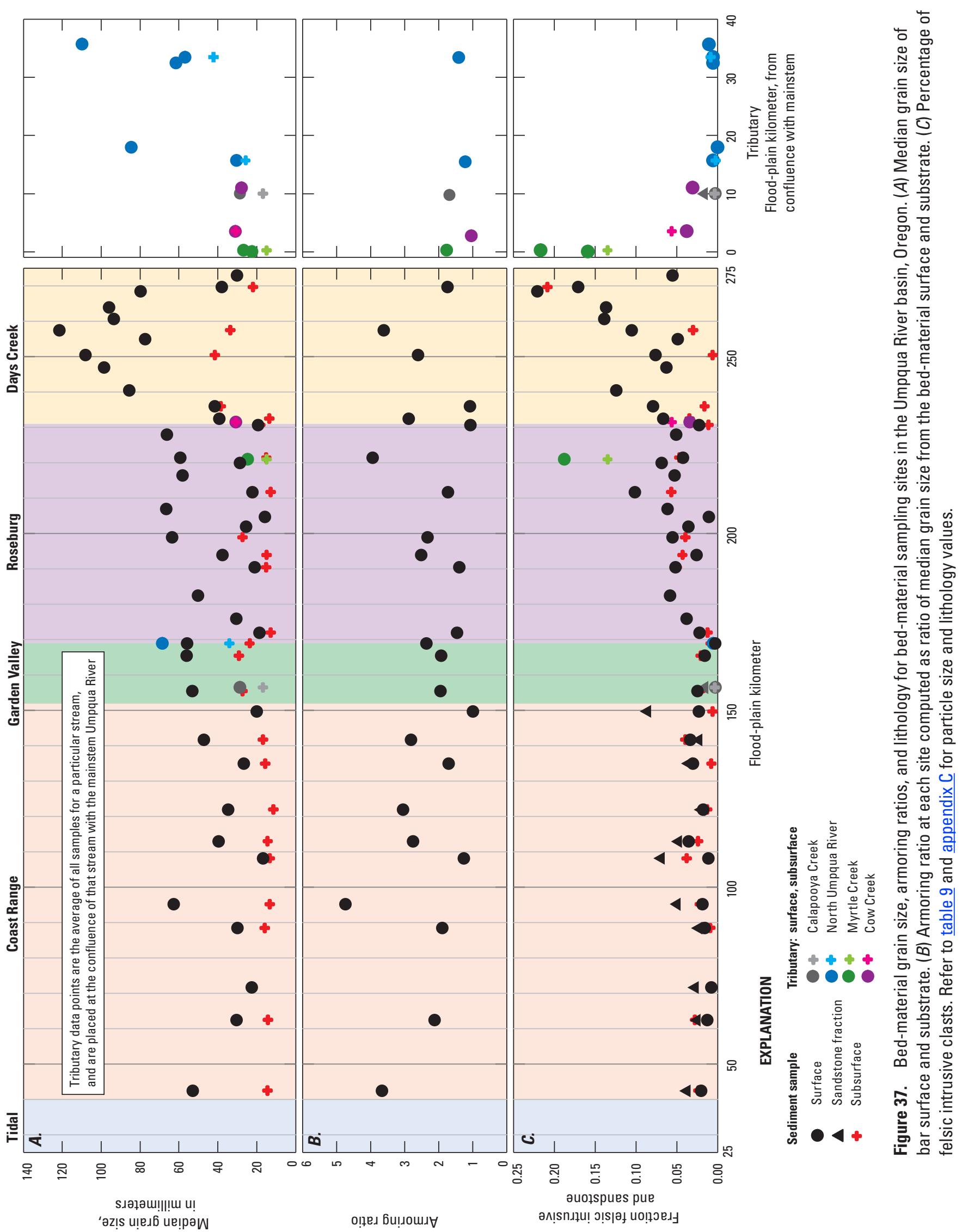


The limited sampling conducted on tributary streams indicates that surface material entering the South Umpqua and Umpqua Rivers from Cow Creek, Myrtle Creek, and Calapooya Creek generally is finer than the bed-material sediment in the main stem channel. The two sampling sites on Cow Creek had $\mathrm{D}_{50}$ values of 27.7-30.9 mm, compared to an average $\mathrm{D}_{50}$ of $76 \mathrm{~mm}$ for the Days Creek reach of the South Umpqua River upstream of the Cow Creek confluence. Surface-material samples from the North Umpqua River were coarser than main stem Umpqua River gravel bars, but this may be partly due to the location of the North Umpqua River sampling sites, which were more than $15 \mathrm{~km}$ upstream of the confluence because of the absence of suitable bars for sampling along the lower reaches of the North Umpqua River.

Although there are too few samples to determine trends regarding sediment supply imbalances on tributary streams, the tributary sites generally are less armored than the Umpqua and South Umpqua Rivers. Cow Creek had the lowest armoring ratio (1.01), consistent with a balance between sediment supply and shear stress, whereas Myrtle Creek and the Calapooya Creek had armoring ratios of 1.78 and 1.66, respectively. The armoring ratios for the North Umpqua River were relatively low (1.17 and 1.34) and probably not representative of overall reach conditions, as these sites had large areas of recently deposited gravel, and essentially no armor layer, whereas all other sites on the North Umpqua River where only bar surface material was sampled appeared substantially armored.

\section{Bed-Material Lithology and Sources}

In addition to measuring sediment texture, clast lithologies were characterized at most surface bed-material sampling sites in order to support inferences of major sources of bed material (see section below, "Basin-Scale Bed-Material Sediment Yield”). Although clasts of many lithologies are present in Umpqua River gravel bars, reflecting the varied source terrains (ig. 1), the assessment was simplified into three broad categories readily distinguished by field inspection: (1) intermediate to coarse-grained felsic igneous and metamorphic rocks (here termed felsic intrusive rocks, chiefly from the Klamath Mountains terrain), primarily light-colored granitic and gneissic rocks, (2) brown sandstones and shales, mainly from the Tyee Formation and equivalents (termed sandstones and mainly from the Coast Range terrain), and (3) all others, which mainly included igneous rocks derived from the Cascade Range. The sandstone category was only assessed at sites downstream of the confluence of the North Umpqua and South Umpqua Rivers; upstream of the confluence, sandstone clasts were rare if present at all.
For the surface-sampling sites, clasts were inspected at 400 points during the particle-count measurements, but classified only if greater than a 16-mm diameter (resulting in total assessed sample sizes at each measurement site ranging between approximately 200 and 400, depending on the surface texture of the bar). Similarly, for the subsurface samples, we classified all sieved clasts greater than $16 \mathrm{~mm}$. The surface samples were done over the 4-week course of field sampling and involved different crew members. Consequently, the categorization of the surface samples may not be as consistent as that for the subsurface samples, which was done in a concentrated effort in the laboratory by a single crew. Sandstone clasts were not categorized for the subsurface samples because they did not reliably survive sieving and transport.

For the surface clast counts along the main stem Umpqua and South Umpqua Rivers, the percentage of felsic intrusive clasts ranged from less than 1 percent to as high as 22 percent. Similarly, the subsurface percentages range from 0.6 to 20.9 percent. The North Umpqua River has few sources of felsic intrusive clasts, reflected in the counts of 1 percent or less. Myrtle Creek and Cow Creek, both of which drain parts of the Klamath Mountains terrain (fig. 1), have higher percentages of felsic intrusive clasts, with Myrtle Creek having one surface sample exceeding 20 percent (table 9).

On the main stem Umpqua and South Umpqua Rivers, felsic intrusive clasts were most abundant along the upper reaches of the South Umpqua River and decreased in abundance downstream (fig. 37). The highest concentrations were along the South Umpqua River within the Days Creek reach, where bar surfaces between FPKM 257 and 269.1 all had felsic intrusive clasts composing more than 10 percent of the surface samples (table 9; fig. 37; appendix C). These high percentages in part owe to the South Umpqua River traversing outcrops of gneiss and coarse-grained schist in this reach, but also to the increasing percentage of total area granitic source terrains such as that drained by Elk Creek, which enters the South Umpqua River at FPKM 272. Downstream, the percentage of felsic intrusive clasts diminishes to values consistently between about 1 and 4 percent.

The percentage of sandstone clasts in the surface samples ranged up to 8.6 percent (table 9; fig. 37; appendix C), but typically were less than 5 percent. Although not specifically counted upstream of the confluence of the North Umpqua and South Umpqua Rivers, they were exceedingly rare if present at all, almost certainly accounting for less than 1 percent of surface clasts. The overall distribution of sandstone clasts reflects the near absence of Paleogene sedimentary rocks upstream of the confluence of Lookingglass Creek at FPKM 119.4, and the increasing area of sandstone sources downstream within the Coast Range terrain. 


\section{Estimation of Bed-Material Transport Capacity from Transport Equations}

Equations of bed-material transport use channel hydraulics and sediment characteristics to estimate sediment fluxes on streams. Although subject to certain assumptions and limitations, such equations can be applied for any stream where information on flow, channel geometry, and bed-material characteristics is available (Collins and Dunne, 1989; Gomez, 1991; Hicks and Gomez, 2003). Moreover, these formulas provide a relatively rapid means of estimating sediment flux across a range of flow scenarios, from individual storm events to decades. For the Umpqua River study area, multiple transport equations were applied for 39 of the sediment sampling sites between FPKM 43 and 270, as well as for sites of three long-term gaging stations. These calculations encompassed the period 1951-2008, aligning with the flow record available from all three gaging stations. The approach applied to the Umpqua River study area largely follows from that applied to the Chetco River in southwestern Oregon (Wallick and others, 2010).

Although several empirical and semi-empirical transport equations are available for bedload transport (Gomez and Church, 1989), all these relations actually predict sediment transport capacity, defined as the "maximum load a river can carry" (Gilbert and Murphy, 1914, p. 35). For situations where there is unlimited bed material available from upstream sources, as well as local erosion from the channel bed and banks, a correct relation for transport capacity coupled with accurate descriptions of flow and bed material should result in accurate estimates of bed-material flux. For the Umpqua River system, however, the assumption of unlimited sediment supply is not valid, as indicated by (1) the extensive and bare bedrock surfaces in and flanking the channel (fig. 16; Howard, 1998; Klingeman, Professor Emeritus, Water Resources Engineering, Oregon State University, written commun., 2010) and (2) the abundant bars with armor values exceeding 2 , thereby suggesting either high transport capacities relative to the supply of fine-grained bed-material or low-transport capacity relative to the supply of coarse-grained bed material (fig. 37). This situation contrasts with that of the similar analysis conducted for the Chetco River in southwestern Oregon, where the low-flow channel is formed in gravel and flanked by voluminous gravel accumulations forming a nearly continuous swath of tractively transported bed-material sediment for the lowermost $18 \mathrm{~km}$ (Wallick and others, 2010). For the more sediment-limited Umpqua River, consequently, calculated transport capacities are best considered indicative of maximum plausible bed-material transport rates, and likely overestimate actual fluxes by substantial margins.
Even in more sediment-rich situations where river conditions satisfy the requirement that bed-material transport is a function of flow, channel, and bed texture rather than sediment availability, large uncertainties still arise because bed-material transport is highly variable in time and governed by highly nonlinear relations between local flow and bed-material transport - both of which are difficult to characterize at high resolution (Gomez, 1991; Wilcock and others, 2009). These challenges, in conjunction with the wide variety of field situations and few measurements, in part explain the large number of transport equations available and the variation in their forms and data requirements (Hicks and Gomez, 2003). For this study, we assess and possibly mitigate for these factors by (1) evaluating multiple transport relations for multiple cross sections, (2) where possible, characterizing flow at individual cross sections using the results from a one-dimensional flow model, and (3) evaluating the results in the context of other information on sediment transport rates.

\section{Equation Selection and Analysis}

The bedload transport calculations for the Umpqua River were implemented by the software package Bedload Assessment in Gravel-bedded Streams (BAGS), a program operating within a Microsoft ${ }^{\circledR}$ Excel ${ }^{\circledR}$ workbook (Pitlick and others, 2009; software and documentation available at http:// www.stream.fs.fed.us/publications/bags.html). The BAGS software enables users to select from six semi-empirical transport formulas that were developed and tested using data from gravel or sandy-gravel streams (Wilcock and others, 2009). Users specify a transport equation and provide information describing channel geometry, flow, and sediment parameters. With this information, bed-material transport rates are calculated for a specific flow and cross-section geometry.

The bedload transport formulas implemented in BAGS are:

- Parker-Klingeman-McLean, a subsurface-based equation (Parker and others, 1982)

- Parker-Klingeman, a subsurface-based equation (Parker and Klingeman, 1982)

- Bakke and others, a calibrated equation version of the Parker-Klingeman formula (Bakke and others, 1999)

- Parker, a surface-based equation (Parker, 1990a, 1990b)

- Wilcock, a two-fraction calibrated model for sand and gravel, (Wilcock, 2001)

- Wilcock and Crowe, a surface based equation (Wilcock and Crowe, 2003) 
Although all six formulas are substantially similar and have been successfully applied to gravel-bed rivers, key attributes differentiate the equations, elaborated in Wilcock and others (2009). The subsurface-based methods (Parker-Klingeman-McLean and Parker-Klingeman) rely on grain-size data from the bed subsurface, beneath the coarser cobble-pavement forming the surface of most bars. Both subsurface-based approaches were developed from measurements made by Milhous (1973) at Oak Creek, a small gravel-bed stream in the Oregon Coast Range. By contrast, two surface-based methods are based on grain-size distributions from bed surfaces. The Parker (1990a, 1990b) equation is a surface-based method also developed from grain-size distributions and transport rates at Oak Creek, whereas the second surface-based method implements the Wilcock and Crowe (2003) equation, which is partly based on the Parker (1990a, 1990b) approach, but is supplemented by flume experiments evaluating the role of sand content on gravel transport.

The main distinction between the two surface-based approaches is in the determination of the reference Shields shear stress $\left(\tau^{*}{ }_{\text {rsg }}\right)$; in the Parker $(1990 \mathrm{a}, 1990 \mathrm{~b})$ equation, $\tau^{*}{ }_{\text {rsg }}$ is assumed to be a constant value of 0.0386 , but in the Wilcock and Crowe (2003) equation, $\tau^{*}{ }_{\text {rsg }}$ varies with the sand content of the surface material. The two calibrated equations of Bakke and others (1999) and Wilcock (2001) require measurements of bedload transport to calibrate reference shear stress, and thus improve the overall transport estimates. These relations are not applicable to this study because of the absence of direct measurements, resulting in the implementation being restricted to the four uncalibrated transport capacity relations.

On the Umpqua River, bedload transport capacity was estimated at a total of 42 sites along the main stem Umpqua and South Umpqua Rivers, including the 39 bed-material sampling sites and the 3 gaging station locations (table 9). Transport also was estimated for two sites on lower Cow Creek, including the gaging station on lower Cow Creek and a nearby bed-material sampling site. Each calculation requires information on flow, bed-material size distribution, cross-sectional geometry, and water or energy-surface slope. No accurate and consistent sources of these measurements were available for all sites. Consequently, information was derived from various sources: flow data were obtained from the USGS gaging stations; sites within the Coast Range and Garden Valley reaches were assigned discharges from the gaging station at Elkton (14321000); and flow records from the gaging stations at Brockway (14312000) and Tiller (14308000) underlie the calculations for the Roseburg and Days Creek reaches, respectively. The gaging station near Riddle on Cow Creek (14310000) was used to calculate transport for the two sites on Cow Creek.

Because nearly all transport capacity calculations were made at August 2009 bed-material measurement sites, these bar-texture measurements were used directly in the transport equations and were applied to the entire cross section. For the four sets of calculations at the gaging stations for which there were no sediment texture measurements, we averaged grain-size distributions from adjacent measurement sites (table 9). At the 15 analysis sites where only bar surface material was sampled, only the surface-based equations of Parker (1990a, 1990b) and Wilcock-Crowe (Wilcock and Crowe, 2003) were applied, whereas at the remaining 24 sites where bar subsurface material was sampled (as well as for the gaging stations where subsurface grain sizes were estimated from nearby sample locations), we also applied the subsurface-based formulas of Parker-Klingeman (1982) and Parker-Klingeman-Mclean (1982).

Cross-section geometry information was limited by the lack of continuous and high-resolution topographic and bathymetric data. For transport calculation locations between FPKM 83.5 and FPKM 155 (Coast Range reach and lower part of the Garden Valley reach), channel cross sections were extracted from a 2009 LIDAR survey (table 7). Elsewhere, cross sections were extracted from the USGS National Elevation Data 1/3 arc second digital elevation model (approximately $10 \mathrm{~m}$ resolution, U.S. Geological Survey, 2010c). For all sites except the Days Creek reach, a trapezoidal cross-section shape was assumed, and the cross sections extracted from these elevation data were adjusted to reflect actual streambed topography using early 1970 s thalweg elevations from USGS flood studies of the Umpqua and South Umpqua Rivers (Oster, 1972, 1973; table 7). The highly stable, chiefly bedrock channel (fig. 30) reduces the uncertainty introduced by using such old channel-depth data. These flood studies did not include the Days Creek reach; therefore, streambed elevations within this reach were estimated to be $1 \mathrm{~m}$ below water surface indicated by the digital elevation models - a value broadly consistent with observations by field personnel. At the three analysis sites located at streamflow-gaging stations, channel cross sections were obtained from recent USGS measurement surveys (U.S. Geological Survey, 2010a).

A key hydraulic variable for computing transport rates is the energy slope $(\mathrm{Sf})$, which was approximated using water surface slope (Sw). For the Coast Range, Garden Valley, and Roseburg reaches (FPKM 41-231), Sw was obtained from the 0.1 annual exceedance probability flood profiles calculated by a one-dimensional step-backwater model (Oster, 1972; 1973; 1975). From these calculated water-surface profiles, we extracted water-surface slope for distances ranging between 550 and $850 \mathrm{~m}$ and spanning the transport capacity calculation location (in nearly all cases, sites of bed-material size analyses). For the Days Creek reach, Sw was determined for 1- to 2-km-long channel segments spanning the analysis sites using low-flow water-surface elevations, as depicted by 5 -ft contour intervals on the USGS 1914 Plan and Profile surveys (Marshall, 1915). 
On the basis of these morphologic, bed-texture, and hydraulic characterizations, we calculated bed-material transport rates for 26 discharges spanning the range of historical flows recorded at nearby USGS streamflow-gaging stations. Using an approach similar to that applied to the Chetco River (Wallick and others, 2010), the results for each discharge produced a relation between discharge $(\mathrm{Q})$ and bed-material transport rate $(\mathrm{Q} s)$, which were fitted by 5 th order polynomial curves to produce sediment-discharge rating curves for each analysis site (fig. 38). Although sediment discharge rating curves are typically modeled using power law relationships (Wilcock and others, 2009), the 5th order polynomial curves provided a better approximation of the Q-Qs relationship than was achieved using a power law relationship.

In conjunction with discharge records of October 1 , 1988-September 30, 2008, from the corresponding USGS streamflow-gaging stations, the calculated Q-Qs relations enabled calculations of annual sediment transport fluxes at each of the analysis sites. Although annual transport volumes typically are calculated using mean daily values (for example, Collins and Dunne, 1989), the combination of highly nonlinear transport rates and the rapid flow changes in the Umpqua River basin during transport events, cause annual bed-material transport volumes determined from mean daily values to likely underestimate true values. Therefore, annual bed-material transport volumes were based on the unit discharge values acquired every 30 minutes and archived electronically since 1988 (although 15-minute flow data are available for WYs 2006-08, to simplify the calculations, these data were not used). For WYs 1988-2006, transport rates were calculated for each analysis site using the 30-minute unit-flow data and summing total transport for each day.

To extend the record back through WY 1951 and to fill recent periods when unit flow data were not available, relations for each calculation site were developed between daily transport volumes calculated from the unit-flow measurements and mean daily flow for all days of predicted transport. These regressions, which typically had correlation coefficients ranging between 0.97 and 0.99 , were applied to all days to permit calculations for the entire record of October 1 , 1951-September 30, 2008. This analysis period coincides with the construction of the North Umpqua hydropower dams (completed by 1955) and encompasses the construction of the Galesville flood control reservoir in the upper Cow Creek watershed in 1985.

In addition to total transport volumes for each site for each of the four bedload transport capacity equations, we calculated the reference discharge, $Q_{T}, P$, as predicted by the Parker (1990a, 1990b) transport capacity equation. The reference discharge is the flow for which shear stress is equivalent to the reference shear stress required for very small but measurable transport (Parker and others, 1982;
Parker, 1990a, 1990b). This value can be compared to annual flow characteristics to assess the frequency of transport or degree of mobility for each measurement site, thereby providing a measure of how frequently a bar may be subject to mobilization. For the measurements here, we calculated the ratio of the reference discharge to the flood with a 0.67 annual exceedance probability (1.5-year flow) to determine a mobility index (table 9). Sites with ratios of unity or less are predicted to have measurable transport for the 1.5-year flood discharge, but those sites with mobility indexes greater than 1 require larger and less frequent flows for mobilization.

\section{Uncertainty and Limitations}

Bedload transport calculations are sensitive to grain size, slope, depth, and discharge (for example, Wilcock and others, 2009). Hence, uncertainties in these parameters affect our calculations of transport capacity for the South Umpqua and Umpqua Rivers. These uncertainties arise from difficulties in measuring or calculating many of these factors in the complicated river channels of the Umpqua River basin, especially in locations where high-resolution topographic data are lacking. Although grain size is easily measured, many of the Umpqua River gravel bars are heterogeneous, and characterized by patches of various sized clasts and intermittent bedrock. Accordingly, the sampling site location within a particular bar, and the resulting measured grain-size distribution, influences the transport capacity calculations for that site. Additionally, the one-dimensional flow model used to calculate Sw is most valid along straight reaches, yet many of the largest bars in the study area were situated along bends, which are not well represented in a one-dimensional model because the hydraulics are dominated by strong secondary flow currents and bedload transport is almost certainly nonuniform across the channel (for example, Dietrich and Smith, 1984). Other sources of uncertainty stem from the limited bathymetric data available for the study area and our resultant dependence on coarse-scale topographic information to characterize channel geometry and bathymetry at some sites.

Calculations that used ranges of values for grain size, slope, depth, and streamflow were used to evaluate the sensitivity of the calculated bed-material transport capacity values (fig. 39). Using flow data from WY 1999 as the base case scenario, annual transport capacity was calculated at the Umpqua Sand and Gravel Bar (FPKM 171.4) by applying the Parker (1990a, 1990b) equation and individually varying each input parameter. Water year 1999 was selected as a typical year for the sensitivity analysis because although it had a mean annual flow approximately 30 percent higher than the average flow for the period 1955-2004, the peak flow during this year was similar in magnitude to the 1.5-year exceedance event. 


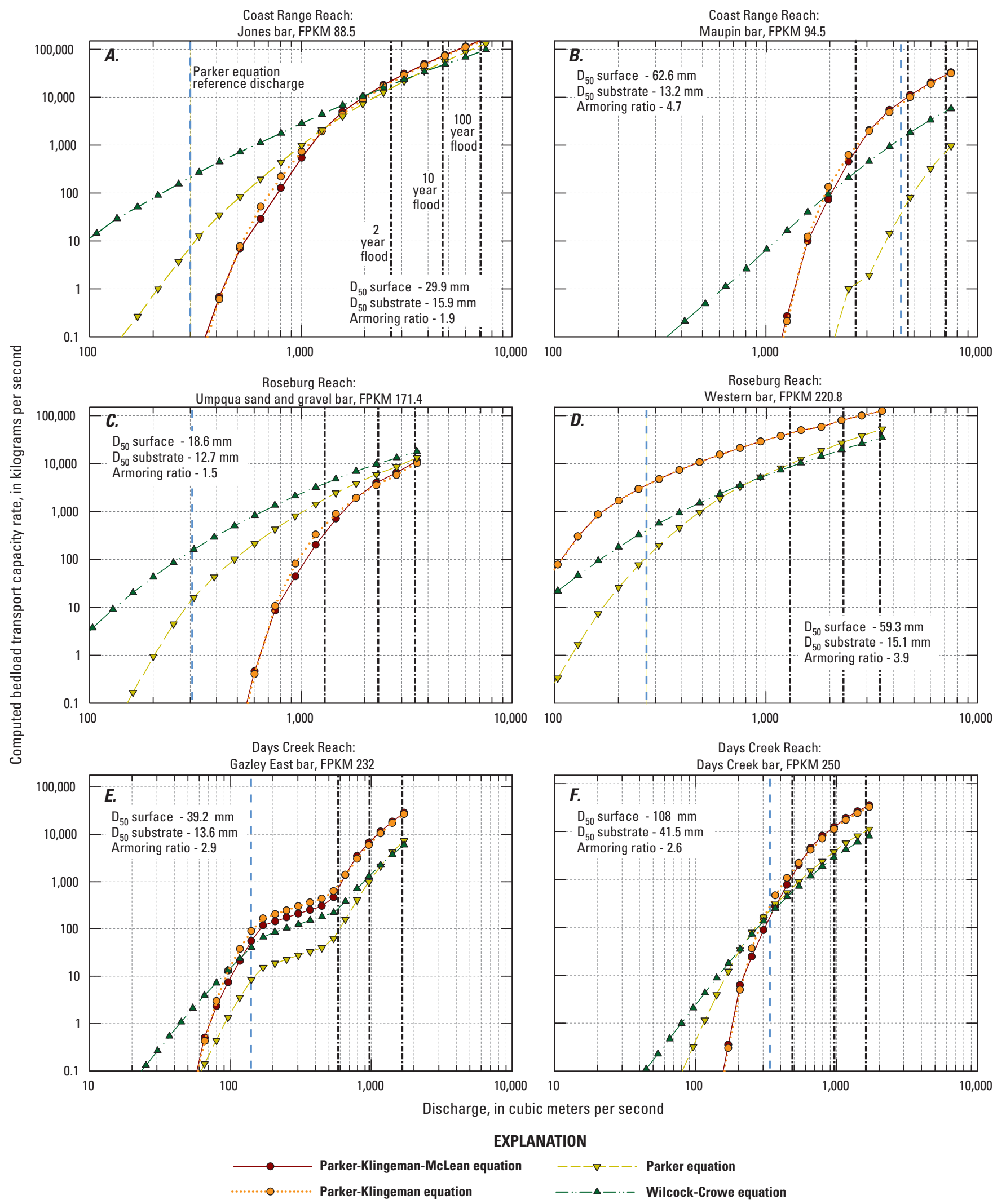

Figure 38. Computed bedload transport rating curves for selected sites in the Umpqua River basin, Oregon, as computed from the Parker $(1990 a, b)$ equation. $D_{50}$ is mean particle diameter; mm, millimeters. 


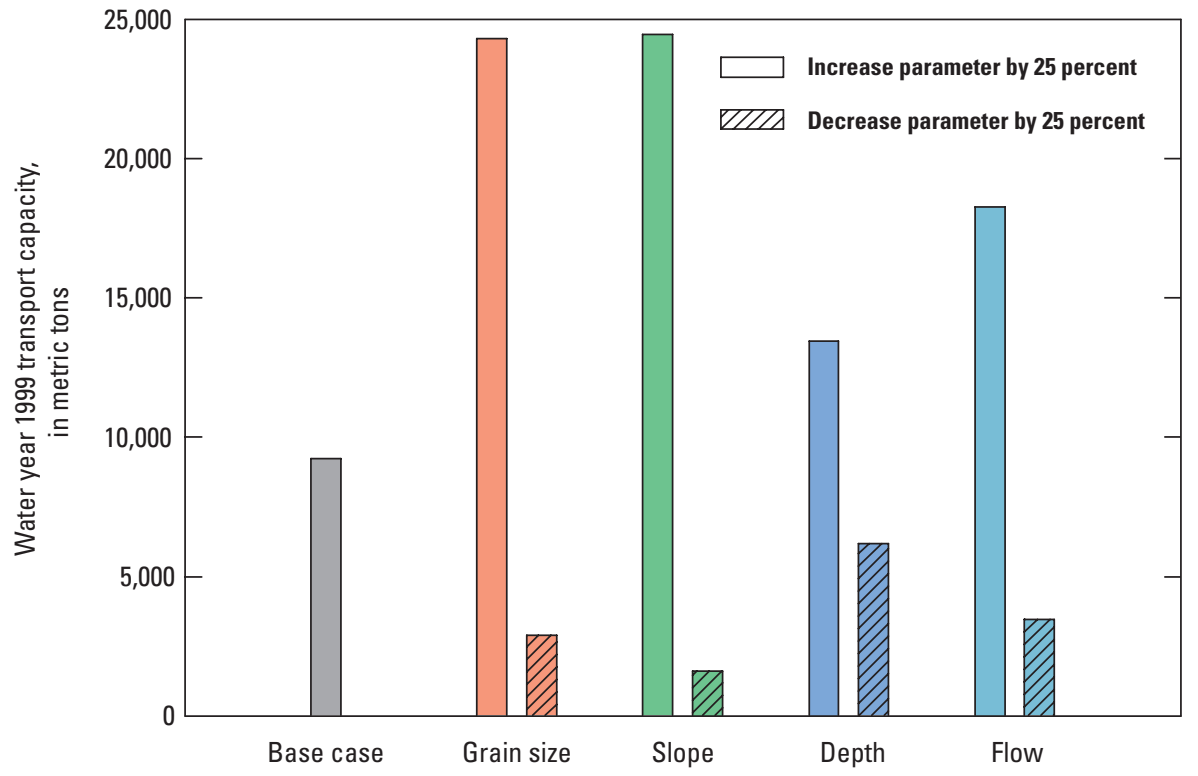

Figure 39. Effect of grain size, slope, water depth, and flow on annual bedload transport capacity. Sensitivity trials conducted for Umpqua Sand and Gravel Bar (FPKM 171.4) for water year 1999 used the Parker $(1990 a, b)$ equation.
Of the four parameters evaluated, annual transport capacity was most sensitive to variation in grain size and energy slope, both of which are affected by the calculated transport rate by about a factor of 2 to 4 when increased or decreased by 25 percent. The transport calculations were less sensitive to mean daily flow values and flow depth, for which a \pm 25 percent variation affected annual transport capacity totals by about a factor of 2 or less (fig. 39). Although this assessment is specific to the Parker (1990a, 1990b) equation, results are likely to be similar for all transport equations because of their similar forms. These results indicate that reasonable uncertainties in the primary factors affecting bed-material transport stem from the heterogeneous nature of gravel bars in the Umpqua River system, which can lead to uncertainties in calculated annual transport volumes approaching a factor of 4 for a specific transport capacity equation. These parameter-related uncertainties are in addition to that resulting from the choice of bed-material transport capacity equation, which is difficult to assess in the absence of direct measurements.

\section{Results of Bed-Material Transport Equations}

Application of the 4 bed-material transport formulas to the 42 sites in the Umpqua River study area for 57 years shows wide temporal and spatial variability in the predicted annual bed-material transport capacities, ranging from negligible transport capacity in some years for many sites to bed-material transport capacities as great as 600,000 metric tons/yr for some sites in high-flow years (table 9; figs. 40 and 41).

The large annual variation at a site owes to the nonlinear relation between flow and bed-material transport capacity (figs. 38 and 41). This is evident by considering the Umpqua Sand and Gravel Bar at FPKM 171.4, for which the mean annual transport capacity for 1951-2008 is 9,070 metric tons/yr as calculated by the Parker (1990a, 1990b) equation, which is similar to the 8,850 metric tons/yr median value for all 27 calculation locations in the Days Creek and Roseburg reaches. At the Umpqua Sand and Gravel Bar, two-thirds of the years have calculated transport capacities less than the mean value of 9,070 metric tons/yr (fig. 41C). The high frequency of low transport years is compensated by a few years of much greater transport capacity: 9 years with values greater than 20,000 metric tons/yr, and exceptional years, such as 1956, 1965, 1974, and 1997 with bed-material transport capacities exceeding 30,000 metric tons/yr (fig. 41C). Considering the calculated daily transport values for the 58-year period of record, the Parker (1990a, 1990b) equation predicts transport on about 15 percent of all days. Half, however, of the total cumulative calculated transport capacity for the Umpqua Sand and Gravel Bar occurred over 80 days (less than 0.4 percent of total days), and 10 percent of the total transport capacity for this 58-year period was over just 6 days, including October 29, 1950, December 23, 1964, and January 16, 1974, which all had transport capacities exceeding 10,000 metric tons.

The annual bed-material transport capacity values for the Umpqua Sand and Gravel Bar decrease significantly ( $\mathrm{P}<0.05$ based on Parker [1990a, 1990b] calculations) over the 58-year period of record. This decrease corresponds to the overall decrease in peak flows since the early 1950s $(\mathrm{P}<0.05$ for USGS streamflow gage at Brockway; fig. 5 , table 2), particularly after 1974 (fig. 41C) and probably reflects regional and longer term climate cycles controlling flow volumes and peak discharges. 


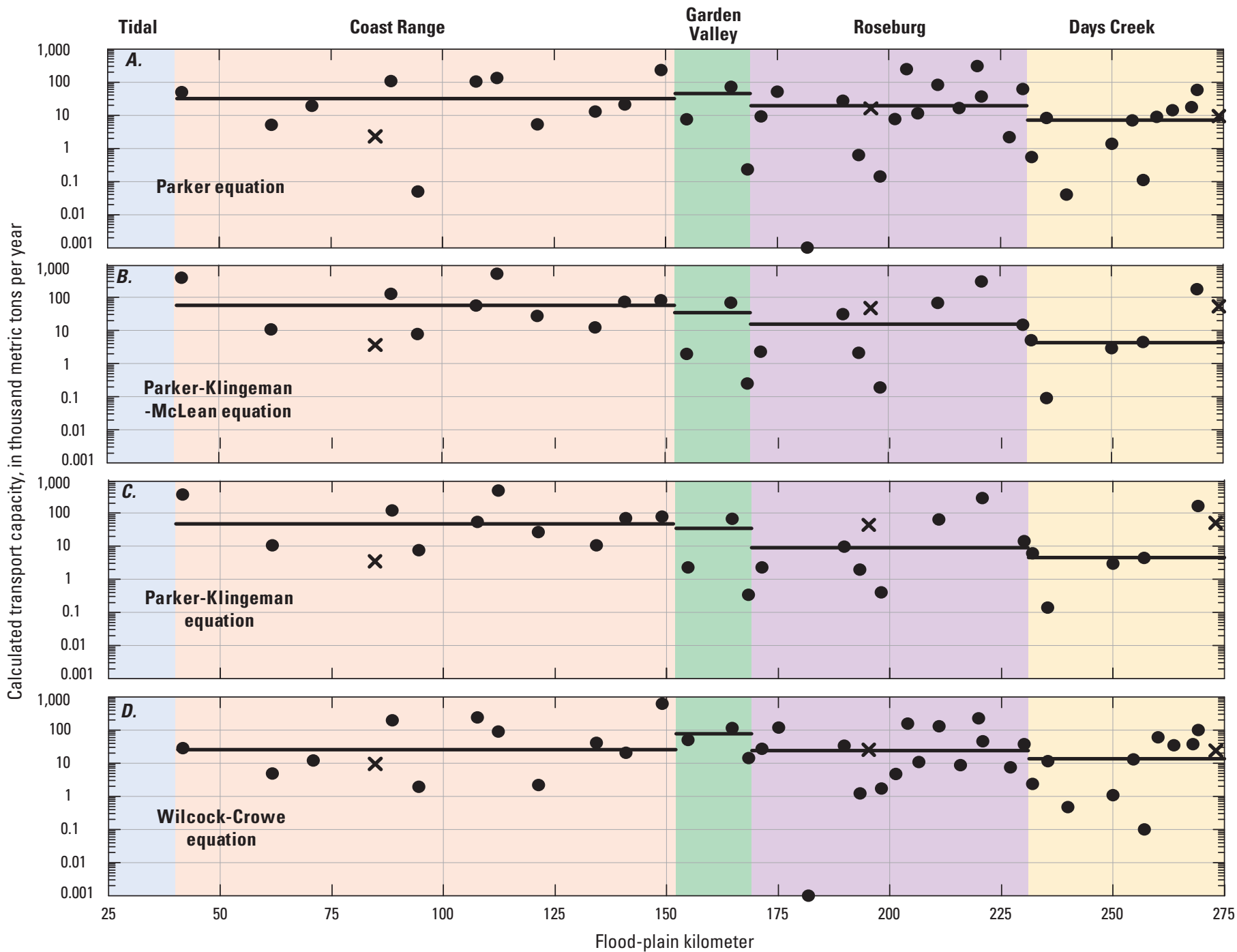

EXPLANATION

Median value for reach

$\times \quad$ Value at gaging station

- Value at sampling site

Figure 40. Longitudinal variation in calculated transport capacity for bed-material sampling sites on the Umpqua and South Umpqua Rivers, Oregon. Data points represent site-specific annual transport, as calculated for 1951-2008, whereas horizontal lines represent median values for each reach. See table 9 for transport capacity values, grain size, and slope data for each sampling site. 

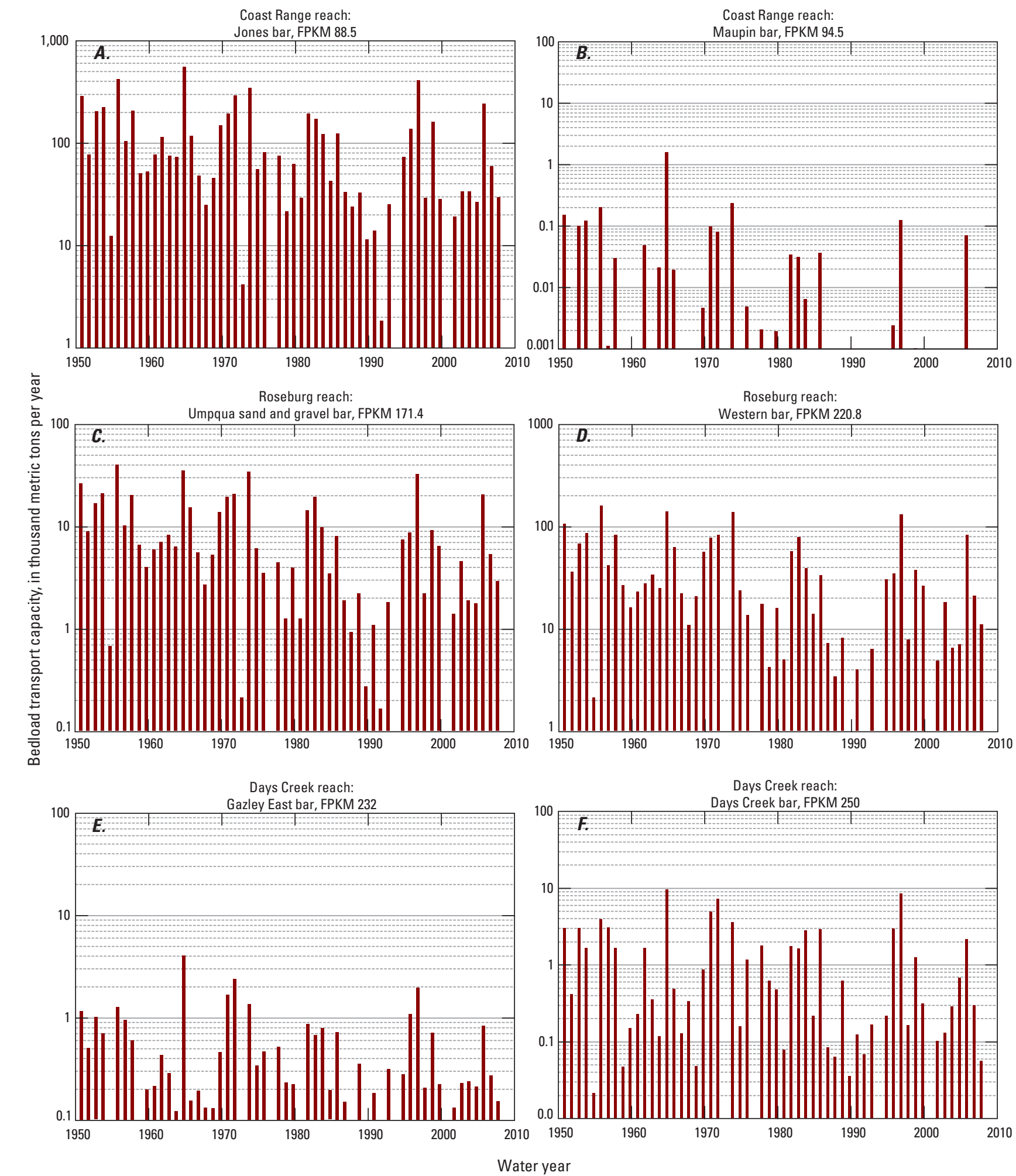

Figure 41. Annual computed transport capacity for water years 1951-2008 for selected sites in the Umpqua and South Umpqua Rivers, Oregon. 
Understanding the spatial variations in calculated transport rates is more challenging. Although the largest bar complexes (including Maupin Bar and those near the confluence of Cow Creek, fig. 20) broadly coincide with zones of decreasing transport capacity, there is considerable site-to-site variability. Average annual transport capacity calculated by the 4 equations and among the 42 calculation locations (39 bars and 3 gaging-station locations) ranges from 0 to 623,000 metric tons/yr (table 9). The two surface-based transport equations (Parker and Wilcock-Crowe) generally predicted greater transport capacity than the subsurface-based equations (Parker-Klingeman-Mclean and Parker-

Klingeman) for sites within the Days Creek, Roseburg, and Garden Valley reaches, but less transport capacity than the subsurface-based calculations for the Coast Range reach. These results are consistent with bar-surface particle sizes decreasing faster with respect to river location than that for subsurface bed material (fig. 37). The two subsurface-based methods (Parker-Klingeman-McLean and Parker-Klingeman) produce similar bedload rating curves (fig. 38), and at most sites, the mean annual transport capacities predicted by the two equations differ by less than 20 percent (table 9). For most sites, the two surface-based equations of Parker (1990a, 1990b) and Wilcock and Crowe (2003) generally agree within an order of magnitude (table 9), with the Wilcock-Crowe equation predicting higher levels of bedload transport at locations where there is a higher proportion of sand.

Median values among the 4 equation-based calculations of average annual transport for the 1951-2008 period for all 39 main stem and South Umpqua River sites for which we had local measurements of bed texture (including the 24 sites where subsurface-based calculations were applied) range from 12,800 to 27,200 metric tons/yr depending on the transport equation. Assessed by reach, the median values increase downstream from 4,450 to 12,620 metric tons/yr in the Days Creek reach to 20,280 to 56,440 metric tons/yr in the Coast Range reach.

Consideration of only these median values, however, masks the six-orders-of-magnitude variation in calculated bed-material transport rates among sites (fig. 40). Although the sensitivity analysis showed that transport capacity calculations are sensitive to both grain size and slope, plausibly affecting the calculated capacity values in this study by as much as a factor of four, the much wider scatter in the computed values for the Umpqua River indicates that other factors are also important. Most of the variation in transport values is the likely result of applying transport capacity equations to a channel system for which bed-material transport is limited by sediment supply rather than transport capacity.

For river systems in which bed-material transport at all locations is limited by flow capacity and for which the channel is in steady state with respect to channel and flood-plain storage of bed material, the expectations are (1) the active channel would be chiefly alluvial and consist of alternating bars flanking a low-flow channel formed in alluvial bed material, (2) all bars would be subject to gravel transport during approximately the same flows, and (3) calculated transport rates would be similar from site to site and variations would chiefly reflect changes in supply resulting from tributary inputs and particle attrition. By contrast, bedrock forms much of the active channel for the Umpqua River, particularly in the Coast Range reach, where the area of bedrock almost everywhere exceeds the area of gravel bars (fig. 18). Moreover, for all reaches of the Umpqua River other than the Tidal reach, the channel flows mostly over bedrock (fig. 19). As a consequence, bar locations and their textural characteristics reflect local hydraulic conditions established by valley and bedrock morphology rather than broad-scale transport conditions (ig. 16).

The diversity of bar types with correspondingly wide-ranging textures is the main reason for the large range of calculated transport capacity values. For example, some bars appear to be largely relic or only active during exceptional flows. Maupin Bar, at FPKM 94.5, for which sequential photographs show little change since 1967, is likely an example of a bar only rarely subject to substantial bed-material transport, which probably occurs during flows similar to the December 1964 flood (fig. 23B, table 9). Aerial photographs and field observations show that although this type of sampling site may appear bare and recently scoured in aerial photographs, many sites (like Maupin Bar) are overlain by a coarse armor layer (table 9 ). Consistent with this observation, these bars have high mobility indexes; the reference discharge (QTP) for Maupin Bar, is 4,400 $\mathrm{m}^{3} / \mathrm{s}$ as calculated by the Parker (1990a, 1990b) transport capacity equation, which is twice the magnitude of the 1.5-year annual peak flow, and similar in magnitude to the 10-year annual peak flow (fig. 38B, table 9).

Infrequent mobility results in low calculated transport capacities. For the case of Maupin Bar, the mean annual transport rate was 50 metric tons/yr as calculated by the Parker (1990a, 1990b) transport capacity equation. Such calculations associated with a stable bar probably do not reflect reach-scale bed-material transport conditions. In contrast, other bars have very low calculated reference discharges, including six with mobility indexes less than 0.1 , indicating that measureable transport is predicted at flows less than one-tenth the $1.5-\mathrm{yr}$ flood. These bars are associated with the greatest calculated annual fluxes, such as the 305,420 metric tons/yr calculated by the Parker (1990a, 1990b) transport capacity equation for the Myrtle Creek Bridge Bar at FPKM 219.9 (table 9). Many of these bars, including the Myrtle Creek Bridge Bar (fig. 26A), Willis Creek Bar (FPKM 204), and Hutchinson Wayside Bar (FPKM 112.3) are in the lee of bedrock protrusions or are otherwise in locations of complicated hydraulics for which bar compositions may more closely reflect local hydraulic and depositional conditions rather than reach-scale bed-material transport conditions (fig. 16). 
The wide range of calculated transport capacity values and the apparent supply limited bed-material conditions for the Umpqua River hinder understanding as to how the calculated transport capacity values might relate to actual bed-material transport rates. Pitlick and others (2009) provide guidance for evaluating such calculations pointing out, on the basis of data reported by Mueller and others (2005), that mobility indexes for most gravel-bed rivers for which flux is inferred to be transport limited range between 0.3 and 1.25. For the Umpqua River bars for which the reference discharge is within this range, the annual transport capacity values range between 600 and 50,000 metric tons. The median value of mobility index for the 45 datasets considered by the Mueller and others (2005) analysis is 0.67 . For the 39 sites on the Umpqua River, the relation between transport capacity (as calculated by the Parker [1990a, 1990b] equation) and site mobility index indicates that a mobility index value of 0.67 correlates to an annual flux of 4,000 metric tons/yr, although the 2-sigma range (95-percent confidence interval) bracketing this prediction ranges from 500 to 33,000 metric tons/yr (fig. 42).

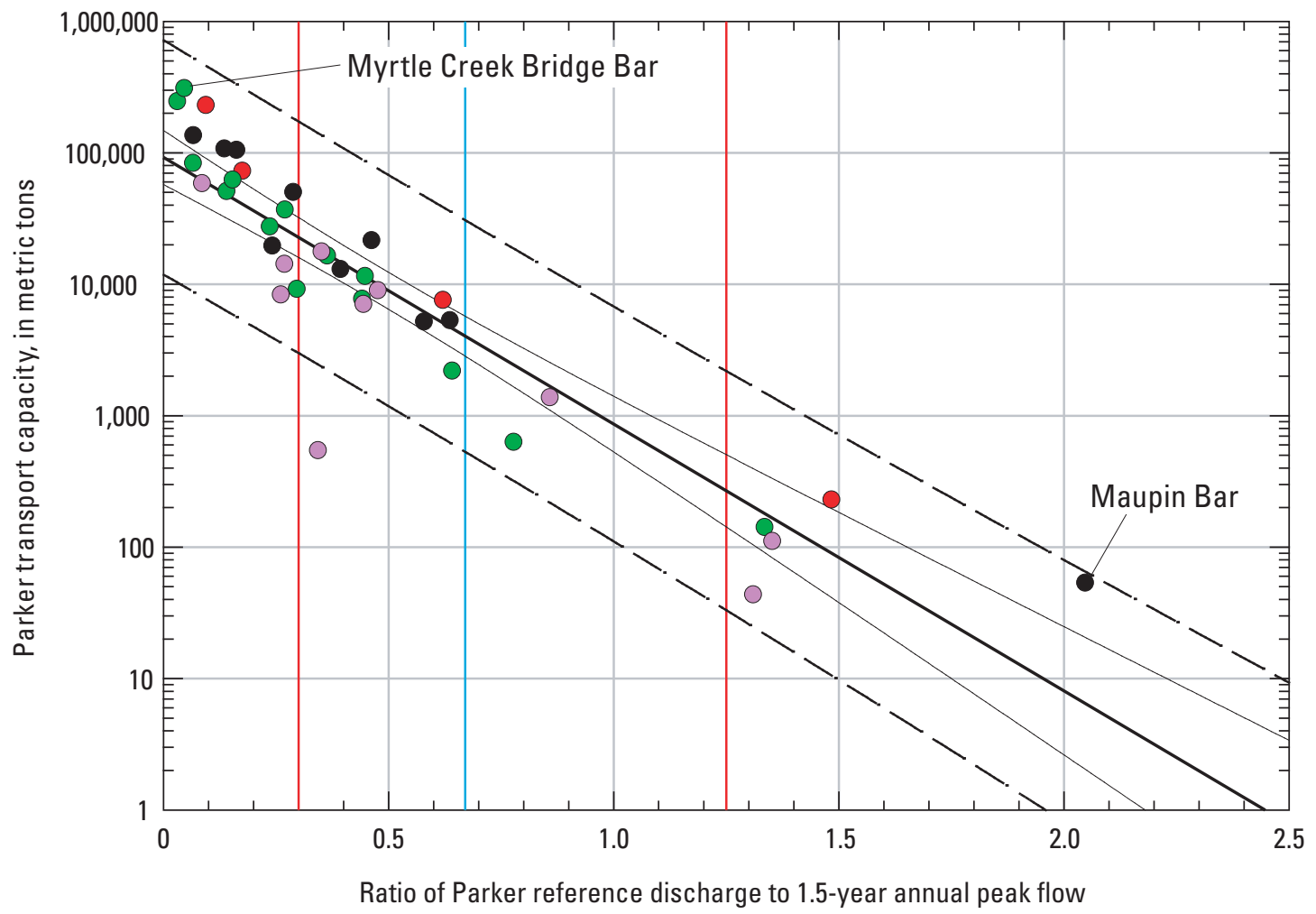

EXPLANATION

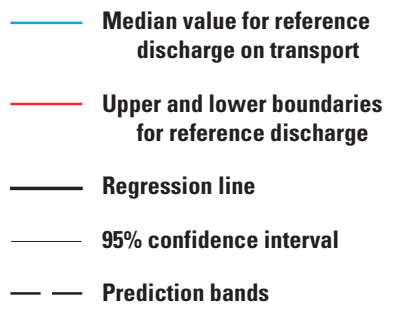

- Coast Range reach

- Garden Valley reach

- Roseburg reach

Days Creek reach

- - Prediction bands

Figure 42. Relation of reference discharge to mean annual transport capacity in the Umpqua and South Umpqua Rivers, Oregon, as computed using the Parker equation. 
The high degree of spatial variability in bed textures and transport rates demonstrates the challenges of applying bedload transport formula to the Umpqua River, where bed-material transport is supply limited. Of the 4 transport formulas applied to the 39 bed-material sampling sites, the surface-based equations of Parker (1990a, 1990b) and Wilcock and Crowe (2003) probably are most applicable because many sites are armored. If bed-material conditions and bar textures were to change, however, than the subsurface-based equations of Parker-Klingeman and Parker-Klingeman-McLean would become more applicable to the study area. Selecting an appropriate range of values to characterize reach-average transport rates is difficult because of the nonuniform nature of Umpqua River gravel bars and transport rates. Consideration of bars with intermediate mobility indexes $\left(0.3<\mathrm{Q}_{\mathrm{T}, \mathrm{P}} / \mathrm{Q}_{1.5 \mathrm{yr}}\right.$ $<1.25$ ) as proposed by Pitlick and others (2009) provides one approach for characterizing actual flux rates, although these rates probably are best considered maximum plausible bed-material transport rates because of the semi-alluvial character of the Umpqua River. In our judgment, the resulting range of annual transport values of 500-20,000 metric tons/yr, as predicted by the Parker (1990a, 1990b) equation for these intermediate mobility sites, most plausibly reflects overall bed-material transport rates, although transport at some sites and for some years will vary substantially from this range.

\section{Basin-Scale Bed-Material Sediment Yield}

An empirical and independent approach to estimating bed-material flux along the Umpqua River was derived from relations between measured sediment yield and predictor variables, such as basin slope, precipitation, and drainage density. This approach is modeled after that used for assessing the sediment yield in the Deschutes River basin of central Oregon (O’Connor and others, 2003) and globally by analyses such as Milliman and Syvitski (1992). In conjunction with estimates of bed-material abrasion rates, this approach permits spatially explicit estimates of bed-material flux for each of the study reaches as well as assessment of the effects of sediment trapping by dams and diversions.

The approach used in this study follows from the premise that basin slope exerts a primary influence on sediment yield. Specifically, in steady-state landscapes dominated by diffusive processes of surficial sediment mobilization (such as biogenic activity, soil creep, freeze-thaw action), sediment flux per unit stream length is proportional to the gradient of the flanking hillslope (Culling, 1960, 1963; Hirano, 1968), although this relation may not be linear in steeper terrains (Andrews and Buckman, 1987; Roering and others, 1999). Consequently, sediment yield per unit area should be proportional to the product of the average slope gradient and drainage density, termed the sediment production index (SPI) by O'Connor and others (2003).
Alternative approaches rely on correlations between sediment yield and precipitation (Langbein and Schumm, 1958; Douglas, 1967; Walling and Webb, 1983, p. 81), and lithology (for example, Schmidt [1985] and Hicks and others [1990]). Hooke (2000) in summarizing available data and analyses concluded that slope steepness and precipitation (as it affects runoff) are the key factors positively correlated with sediment yield but that precipitation is more difficult to assess because it also controls vegetation cover, which is inversely correlated to sediment yield. This study examined correlations between sediment yield and (1) mean basin slope, (2) the product of basin slope and drainage density (SPI of O'Connor and others, 2003), and (3) the product of basin slope and mean annual basin precipitation (following the analysis of Hooke, 2000).

This analysis does not explicitly consider lithology, which has been shown to be a strong predictor of sediment yield in some studies (Aalto and others, 2006; Syvitski and Milliman, 2007), and which is a very important factor for the Umpqua River basin, judging from the correspondence of gravel-bar abundance with Klamath Mountains source areas. The rationale is that geology is difficult to parameterize objectively in a manner relevant to producing bed material, and for many areas in the region is strongly correlated with slope and drainage density (O’Connor and others, 2003; Jefferson and others, 2010).

\section{Sediment Yield Measurements}

Underlying this analysis are 33 measurements of sediment yield from 26 basins in the Cascade and Coast Ranges of Oregon and northern California. Sediment-yield measurements were compiled from reservoir surveys, reservoir delta surveys (surveys of sediment volumes deposited at river or stream entrances into reservoirs), bedload sampling, and bedload transport equations confirmed by sampling. The yield measurements and calculated totals encompass durations of 1 to 95 years and basins ranging from 0.7 to $6,901 \mathrm{~km}^{2}$ (table 10).

This analysis focused on compiling bed-material yield rates from previous studies, which required estimation of the bed-material volumes from the reported total sediment volume measurements. Bed-material transport rates were measured and calculated directly for Oak Creek, Chetco, and Smith Rivers, as well as the measurements from the H.J. Andrews Experimental Forest, so these reported values were used without modification. For studies where the total fluvial load was measured, such as for the Pistol River and Redwood Creek, the bed-material load was assumed to be 20 percent of the suspended load, in broad agreement with the ratio of bed-material load to suspended load measurements at Smith River (which drains similar terrain as Redwood Creek), Redwood Creek, and at the H.J. Andrews Experimental Forest (table 10). 


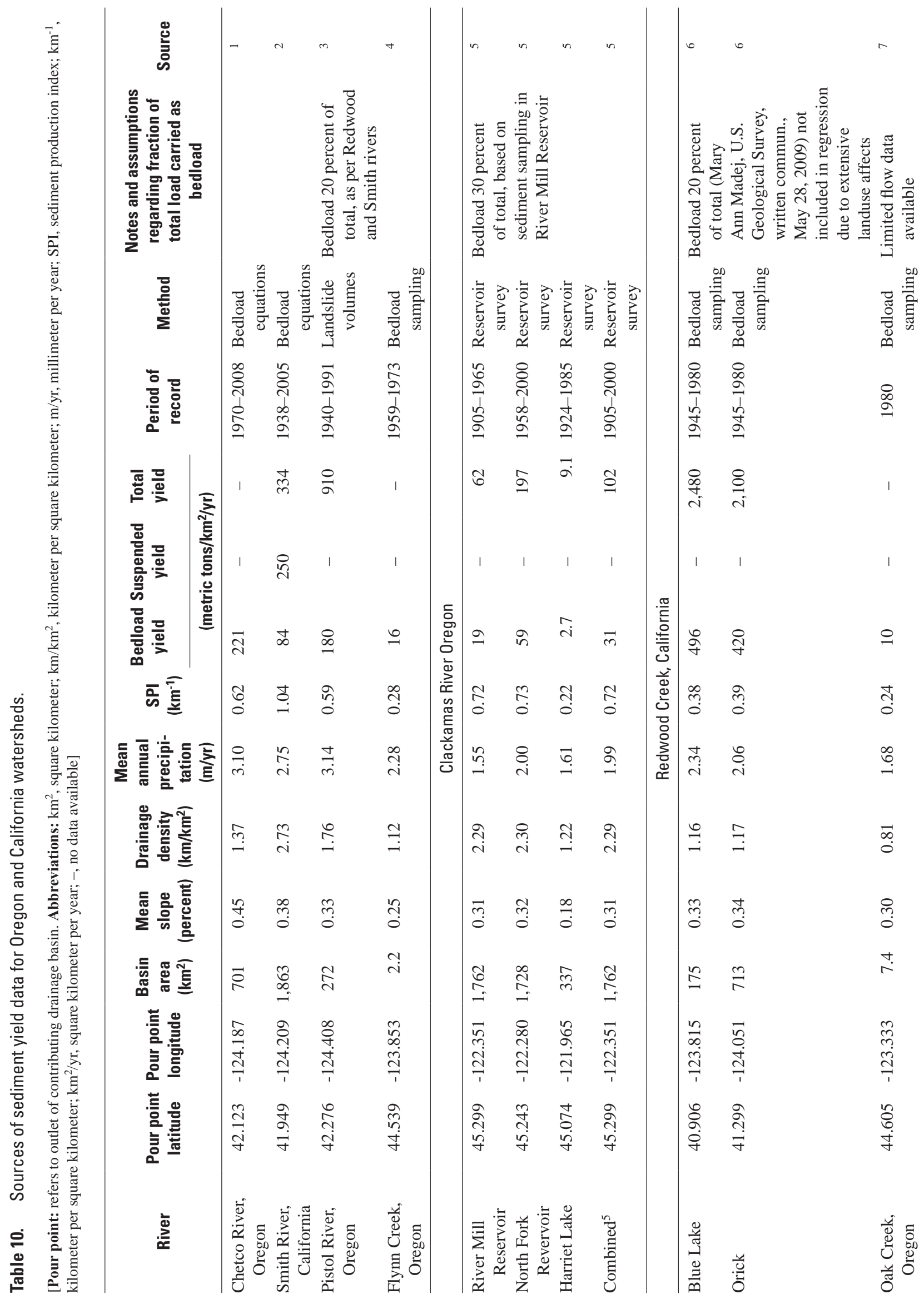




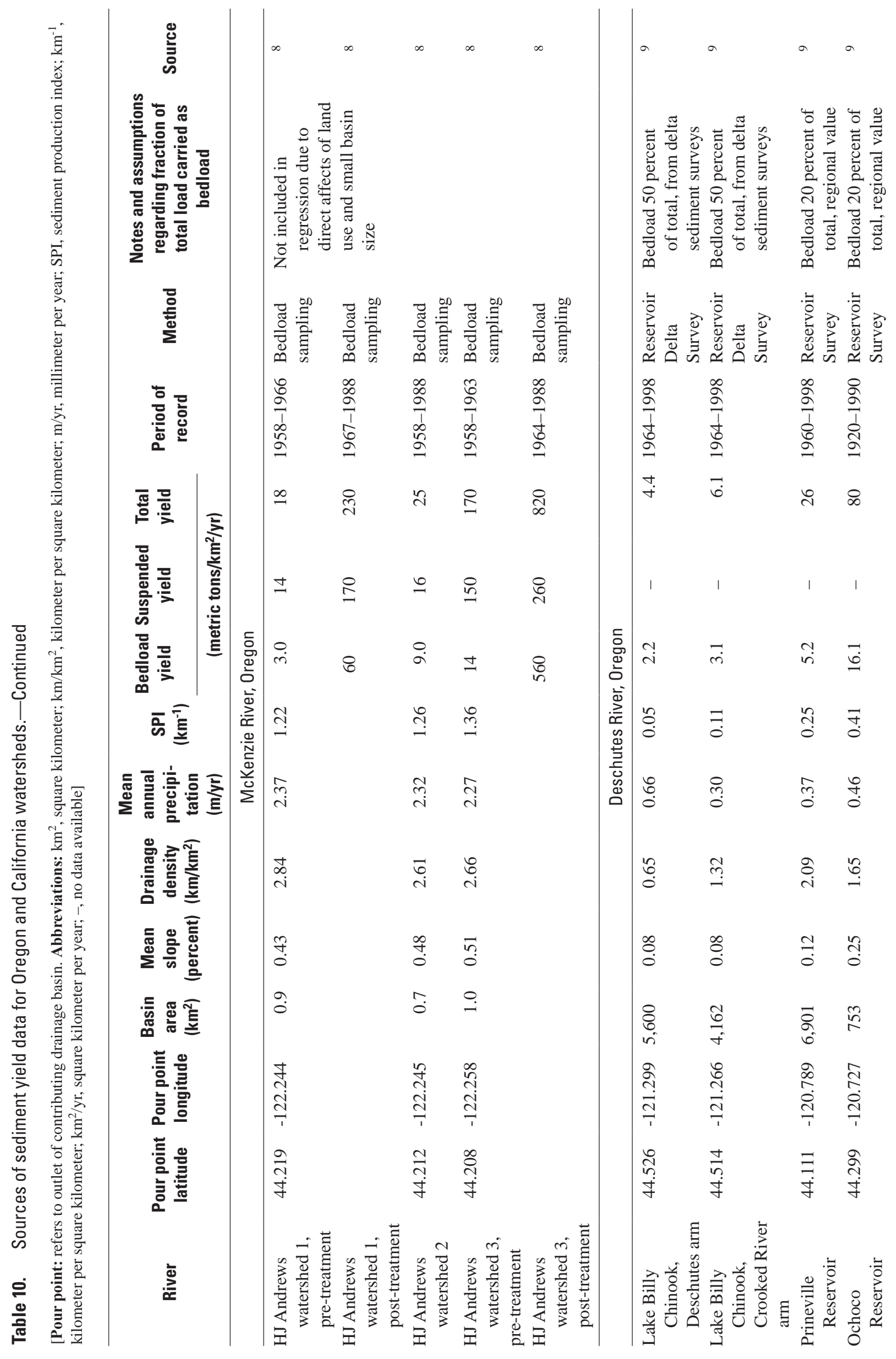




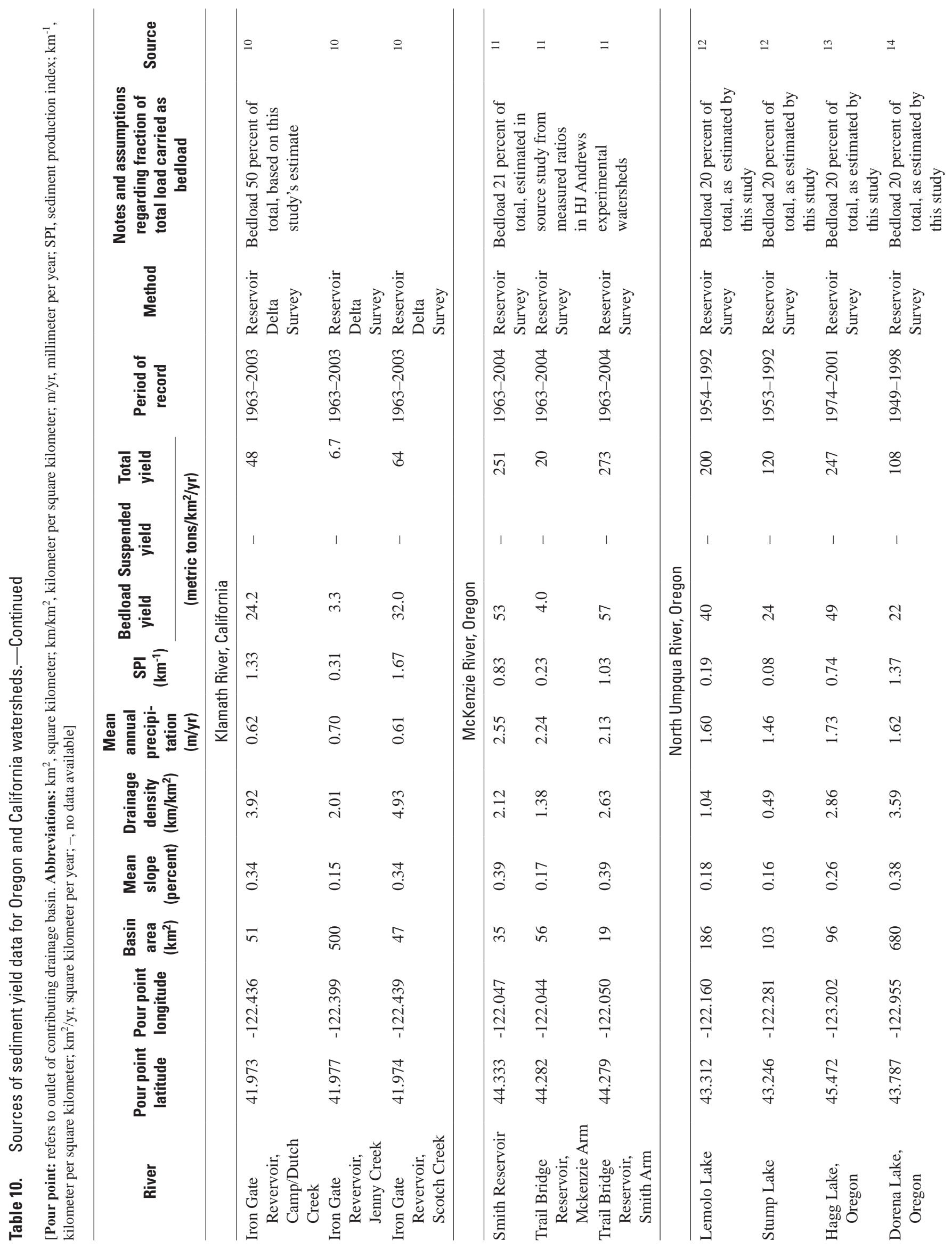




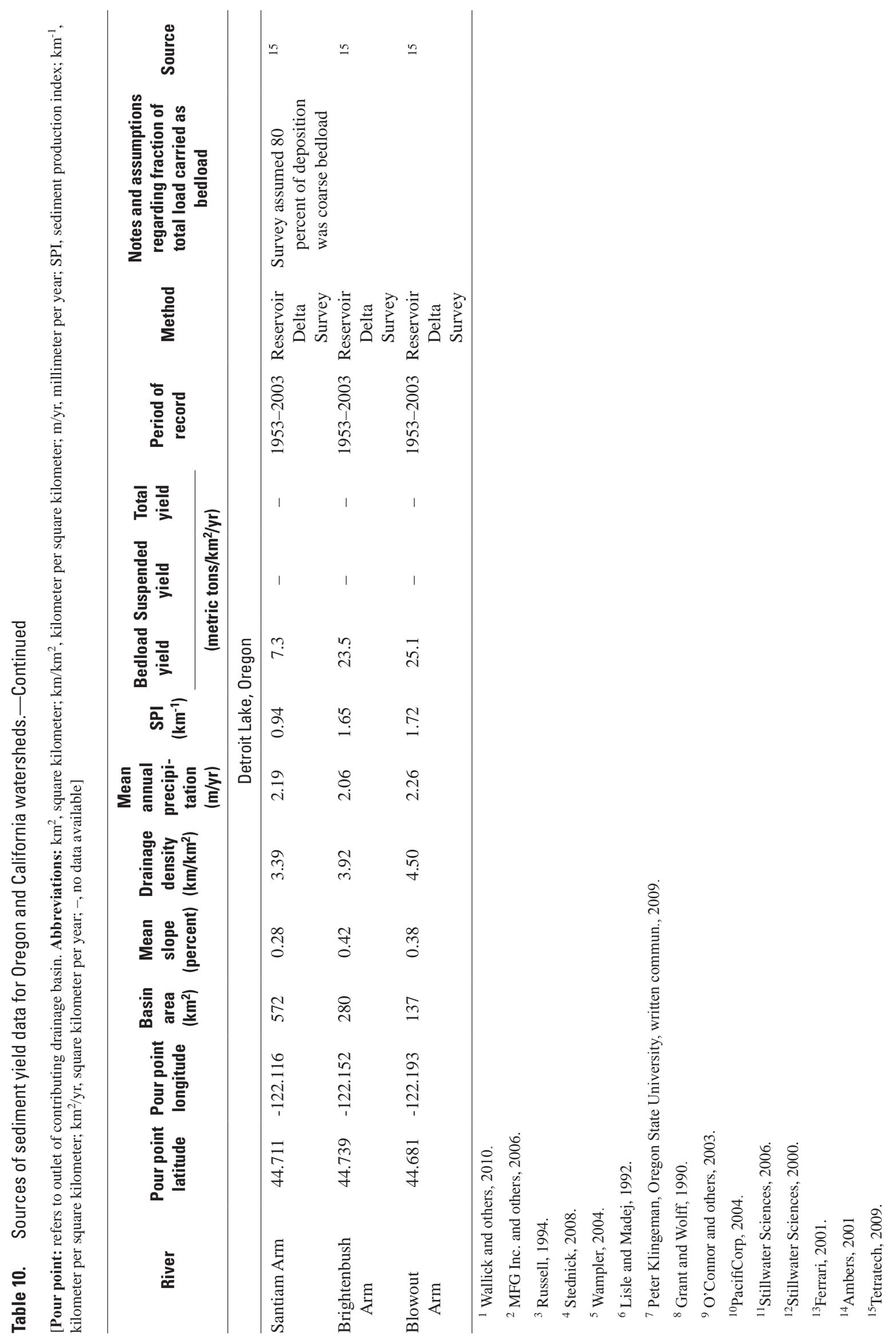


Most of the yield data is from reservoir surveys, for which estimating the percentage of the reported value representing bed material is more challenging, especially for instances where sediment size data are lacking. It was assumed, on the basis of the size composition of bed-material samples collected along the Umpqua River (this study) and the Chetco River (Wallick and others, 2010), that bed material is composed primarily of clasts with diameters greater than $0.5 \mathrm{~mm}$ (coarse sand and gravel) and that finer particles were transported primarily as suspended load. For the full reservoir surveys for which the data sources give no estimate of the portion representing bed material or indication of sediment-size distributions (such as for reservoirs in the North Umpqua and Deschutes River basins), it was assumed that bed material composes 20 percent of the total volume. For the McKenzie River reservoirs, a bed-material percentage of 21 percent was estimated by Stillwater Sciences (2006). For the Clackamas River basin reservoirs, we assigned a bedmaterial percentage of 30 percent on the basis of reservoir sediment samples reported in Wampler (2004).

Several reservoir surveys focused on deltas formed at major points of inflow, allowing estimates of sediment volumes delivered by as many as three basins draining into a reservoir. For most of these surveys of the typically coarser deposits found at tributary deltas, 50 percent of the total volume was assumed to be bed material, based on sediment-size analyses for the delta sediment accumulations in Lake Billy Chinook (Deschutes River; O'Connor and others, 2003) and Iron Gate Reservoir (PacifiCorp, 2004). For Detroit Lake, the volumes in the three surveyed reservoir arms were assumed to be 80 percent bed material, based on grain-size analyses conducted by Tetratech (2009).

\section{Specific Bed-Material Yield}

Analyses were performed with respect to specific bed-material yield $(Y)$ in units of metric tons per square kilometer of contributing drainage basin area. For sediment accumulations originally reported as volumes, such as for all reservoir surveys, bed-material mass was calculated by multiplying the estimated bed-material volume by 2.1 metric tons $/ \mathrm{m}^{3}$. Contributing drainage area was determined for each of the measurement sites through the U.S. Geological Survey (2010d) Streamstats website.

\section{Predictor Variables}

On the basis of previous analyses in the Deschutes River basin (O’Connor and others, 2003) and Hooke's (2000) analysis, correlations between specific bed-material yield and predictor variables involving combinations of mean basin slope ( $\mathrm{S}$; in percent), drainage density (dl; in kilometer per square kilometer), and mean basin precipitation ( $\mathrm{P}$; in millimeters) were assessed. Mean basin slope was calculated from a slope raster map derived from the U.S. Geological Survey National Elevation Dataset 1/3-arc-second (approximately 10 $\mathrm{m}$ resolution) raster digital elevation data (obtained from the U.S. Geological Survey [2010c] The National M ap Seamless Server ). Drainage density was calculated from the total stream length for each basin as mapped in the high-resolution (based on 1:24,000-scale topographic mapping) National Hydrologic Dataset (U.S. Geological Survey, 2010a). Mean annual basin precipitation for 1971-2000 was calculated from 30-arc-second (approximately 800-m resolution) gridded data provided by the PRISM Climate Group (2007) at Oregon State University.

\section{Correlations}

Specific correlations were made between the natural logarithm of specific bed-material yield and (1) mean basin slope, (2) the product of mean basin slope and mean annual basin precipitation, and (3) the product of mean basin slope and basin drainage density (fig. 43). The logarithmic transformation normalized the observations and enabled linear regression fits. Seven of the bed-material measurements were excluded from the correlation analyses: two exceptionally high values from the Redwood Creek basin, where sediment yield was substantially increased by land-use practices in the basin prior to the 1970s (Madej, 1995); and the five measurements from the H.J.

Andrews Experimental Forest because of the very small size of the basins (all less than $1 \mathrm{~km}^{2}$ ) and their unrepresentative experimental treatments. The resulting exponential correlations between specific bed-material sediment yield $(\mathrm{Y}$, in metric tons per square kilometer of drainage area) and three predictor variable sets are statistically significant, although the correlations are much stronger for $S$ and S-P than for S. $\mathrm{dl}$ :

$\mathrm{Y}=1.64 \mathrm{e}^{8.935} \mathrm{P}<0.0001$ (analysis of variance); $\mathrm{r}^{2}=0.58$ ).

$Y=5.13 e^{2.585 * P} P<0.0001$ (analysis of variance); $r^{2}=0.57$ )

$Y=9.59 e^{1.035 * d l} P<0.05$ (analysis of variance); $r^{2}=0.18$ ) 

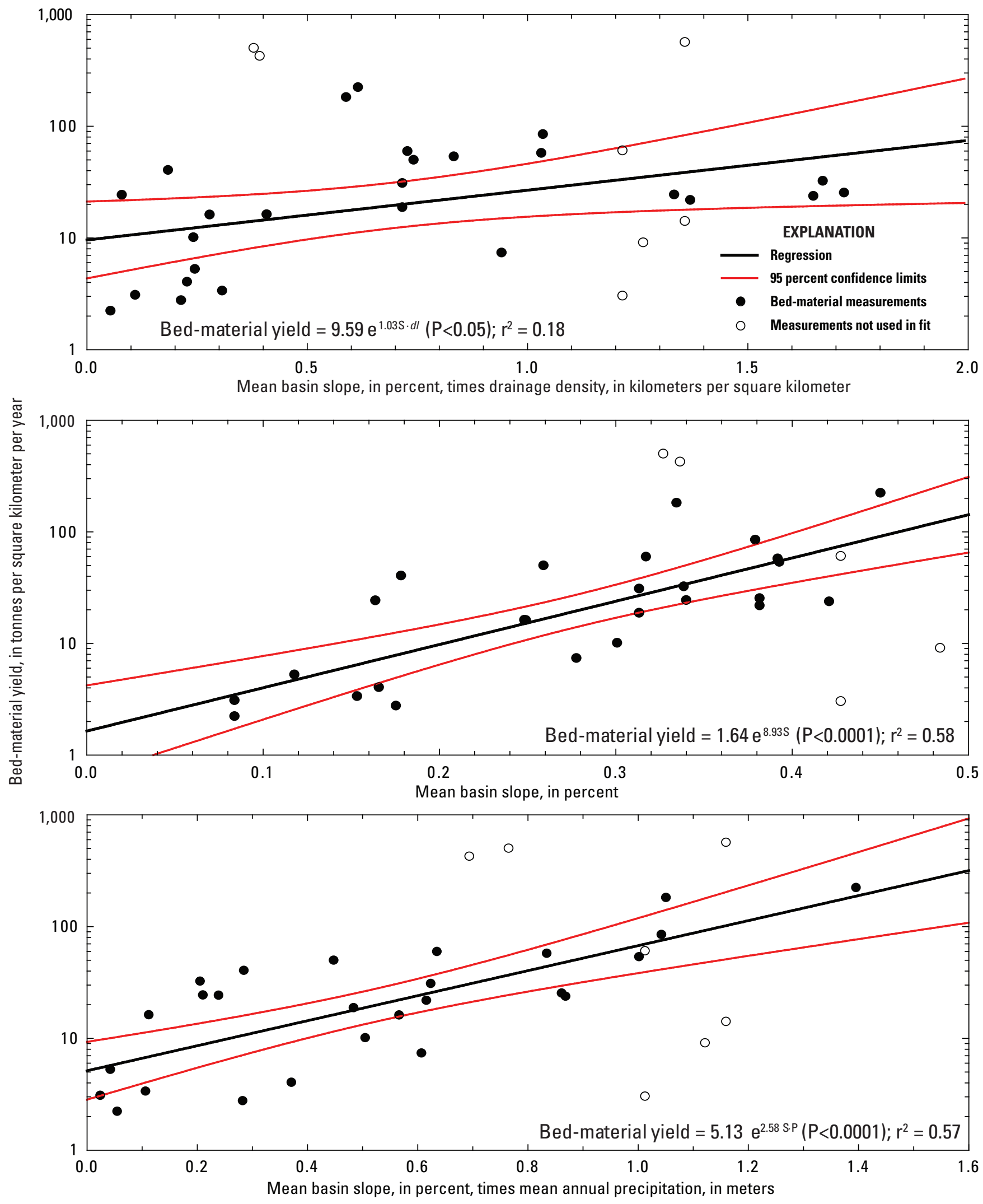

Figure 43. Regional sediment yield regressions, as calculated for 26 basins in Oregon and northern California. 


\section{Application to the Umpqua River}

All three correlations between specific sediment yield and basin-scale predictor variables were applied to the Umpqua River basin. To examine spatial trends in sediment yield explicitly relative to river position, we subdivided the basin into 62 subbasins ranging from 0.16 to $3,190 \mathrm{~km}^{2}$, accounting for major tributaries, dam locations, and bedmaterial sampling locations. For each of these subbasins, total bed-material yield was calculated using equations $2-4$ as well as for the bounding 95-percent confidence limits for the regression (fig. 43). Total yield calculations allow for coarse predictions of bed-material flux to the South Umpqua River and continuing downstream along the main stem Umpqua River channel for the entire study area (fig. 44).

The 95-percent confidence intervals of the regressions imply that uncertainties range from 30 to 70 percent about the calculated specific sediment flux. For example, the predicted sediment flux for the South Umpqua River immediately upstream of the North Umpqua River confluence at FPKM 175.1 is $212,600+140,600 /-129,700$ metric tons/yr for the regression based on the product of slope (eq. 1) and $70,000+29,200 /-20,800$ metric tons/yr for the regression based on the product of slope and precipitation (eq. 2). These flux calculations also show that the regression based solely on mean basin slope (eq. 1) predicts approximately twice the bed-material volume as those resulting from the slope-drainage density (eq. 3) and slope-precipitation (eq. 2) combinations. Although all three predictions of bed-material sediment yield to the Umpqua River exceed local transport capacity in most locations, on the basis of local particle size and bed-material transport equations (fig. 44; table 9), equations 3 and 4 provide mutually consistent bed-material sediment yield predictions more closely matching the transport capacity estimates. From these observations, we judge equation 3, based on the product of slope $(S)$ and precipitation $(\mathrm{P})$, to be most appropriate for estimating sediment delivery to the Umpqua River channel.

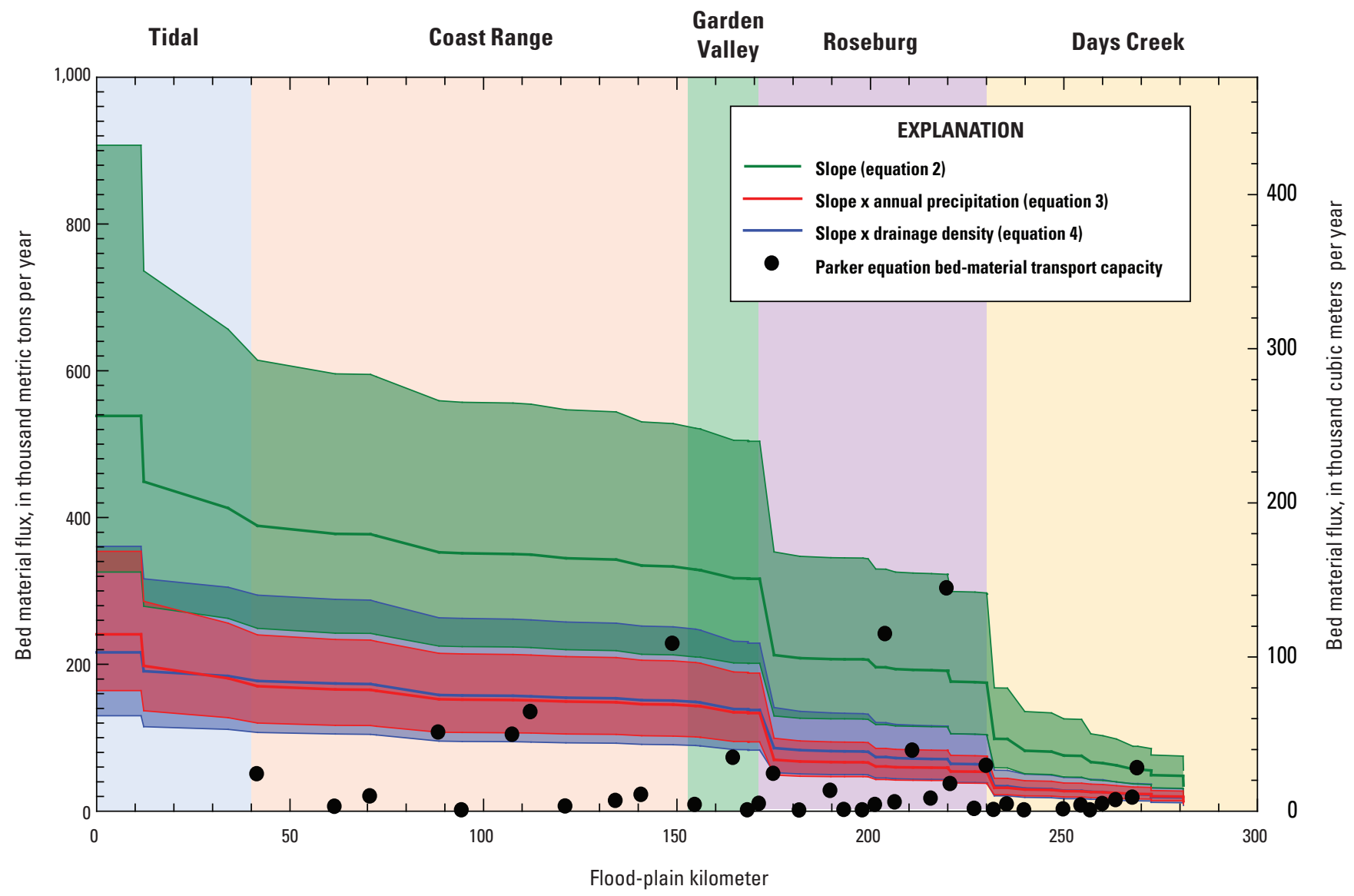

Figure 44. Predicted bed-material yield for South Umpqua and Umpqua Rivers, Oregon. Total yield was calculated by regressions between bed-material flux and different predictor variables (regressions shown in figure 43). Shown here is the predicted yield and range of yields predicted by the 95-percent confidence limits for each regression. 
The predictions shown in figure 44 do not account for bed-material attrition by abrasion or for discontinuities in sediment yield and transport because of dams or other special circumstances. Bed-material attrition along the main stem Umpqua River resulting from fracture, abrasion, dissolution, and weathering and the resulting transformation of bed material to suspended load is accounted for in a similar manner as for the Chetco River analysis of Wallick and others (2010). For sediment generated from the Western Cascades and Klamath Mountains geomorphic provinces (fig. 1), we applied a mass loss rate of 0.51 percent per river kilometer, adopting the rate determined by Shaw and Kellerhals (1982; calculated from their estimate of a fraction-diameter reduction rate of $0.0017 / \mathrm{km}$ ) for quartzites in natural rivers. For the much softer rocks produced from the Coast Range geomorphic province, we assigned a mass loss rate of 18 percent per kilometer on the basis of tumbler experiments with Tyee Formation sandstone clasts conducted by Benda and Dunne (1997). Although this rate seems high relative to that for quartzites, it is consistent with our observations that there were few Coast Range clasts in the gravel bars within reaches supplied by sedimentary rocks of the Coast Range. At the surface sampling sites within the lower reaches, many clasts of Paleogene sedimentary rocks have disintegrated in place (fig. 45) and typically composed less than 5 percent of the bar surface clasts despite these rocks accounting for 10-25 percent of the contributing drainage area at the sampling sites. The rapid attrition of Paleogene sedimentary rock clasts is also supported by the high suspended sediment loads in Coast Range streams (for example, Beschta, [1978]).

By contrast, the fraction of felsic intrusive rocks in surface and subsurface bar sediment samples is consistent with the overall fraction of the basin underlain by felsic intrusive rocks as well as the expected percentage of felsic intrusive clasts as predicted from the sediment yield analysis in conjunction with mapped areas of felsic intrusive rocks (Wells and others, 2001; Ma and others, 2009; table 9, fig. 46). The result of applying the abrasion rates proportionally to the volume of bed material delivered from the different terrains, as predicted from the bed-material sediment yield correlation of equation 3 , indicates that the bed-material flux generally increases downstream to the North Umpqua confluence, but decreases downstream from the North Umpqua confluence as attrition reduces bed-material volume faster than it is replenished by downstream tributaries that furnish mainly soft clasts of Paleogene sedimentary rocks (fig. 47).

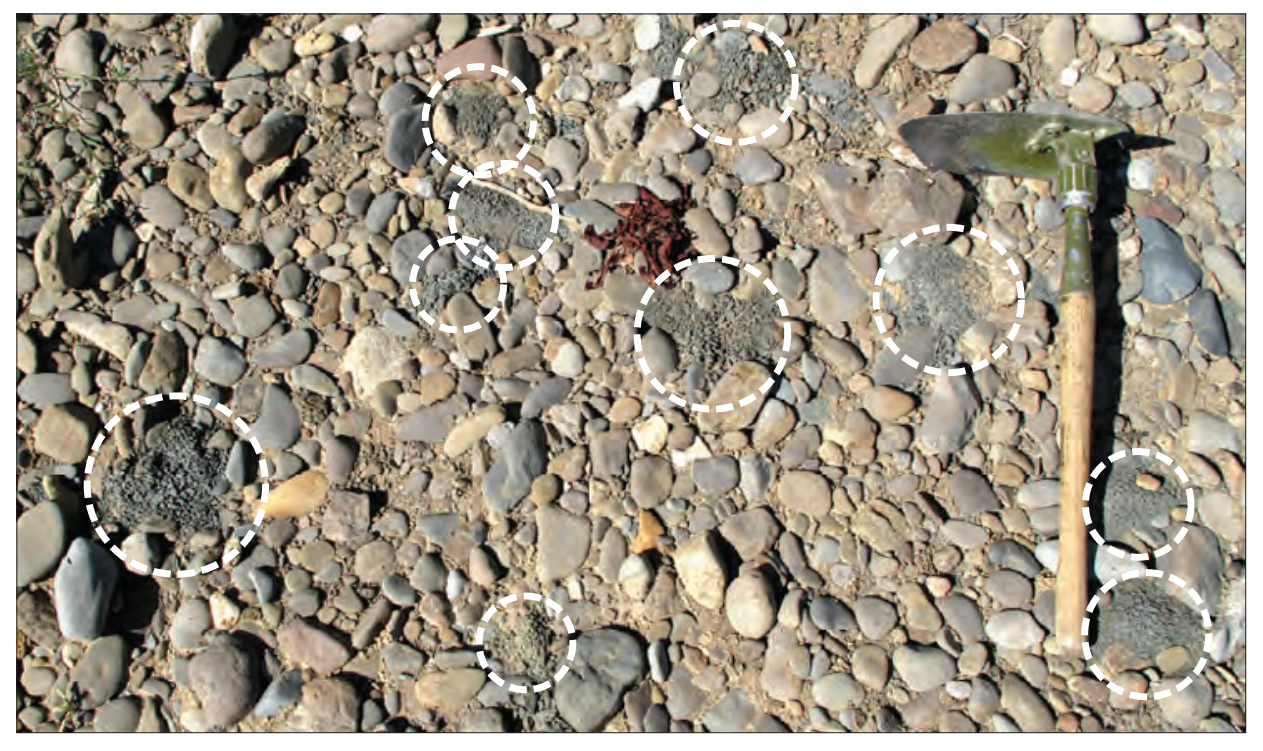

Figure 45. Examples of disintegrating sandstone clasts derived from the Tyee Formation in the Oregon Coast Range. 
We further modified predictions of cumulative sediment yield to account for present river conditions by assuming no bed-material input from the dammed portions of Cow Creek and the North Umpqua River, and from the Smith River, of which the lower $6 \mathrm{~km}$ is estuarine as a consequence of Holocene sea-level rise, thereby inhibiting gravel transport to the Umpqua River (fig. 47). The influence of the Galesville Dam on Cow Creek is small, reducing the total predicted yield at the Cow Creek confluence with the South Umpqua River by 6 percent. The dams on the North Umpqua River likely have had larger effects on total bed-material yield to the
Umpqua River: the calculated volume of bed-material yielded by the North Umpqua River in the absence of impoundments accounts for as much as 65 percent of the total bed material downstream of the confluence with the South Umpqua River. This analysis probably overestimates the historical contribution of the North Umpqua River because of the river's smaller peak flows and the smaller area underlain by Klamath Mountains terrain rocks relative to the South Umpqua River, and neither factor is explicitly accounted for in the bedmaterial sediment yield model.

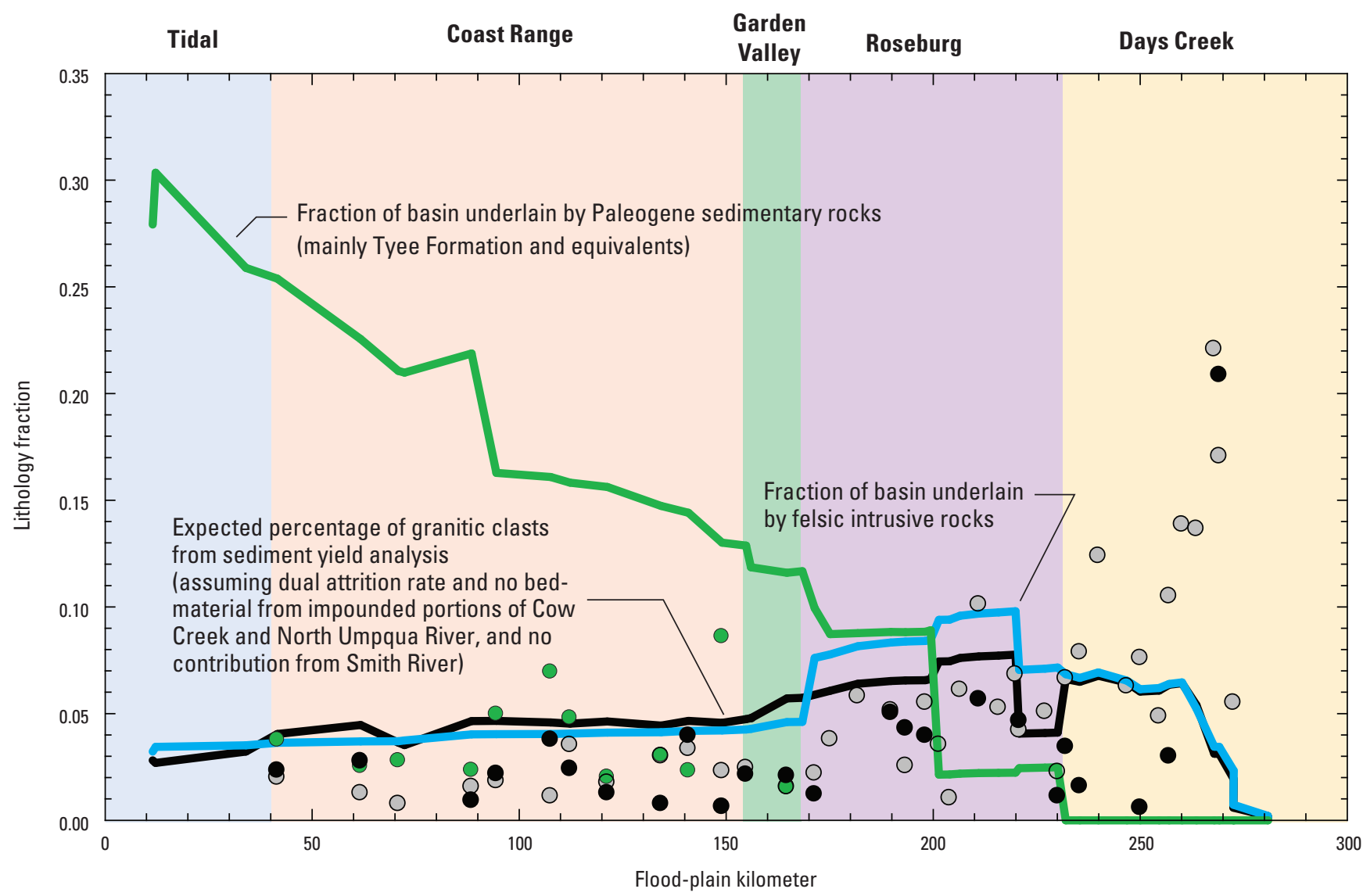

EXPLANATION

\section{Fraction felsic intrusive clasts} in surface samples

- Fraction felsic intrusive clasts in sub-surface samples

- Fraction sandstone clasts in surface samples

Figure 46. Graph showing comparison between longitudinal distribution of clast lithologies in bed-material sampling sites, fraction of contributing area underlain by these lithologies, and expected lithologies based on sediment yield analysis. See table 9 and appendix $C$ for lithology values at sampling sites. 


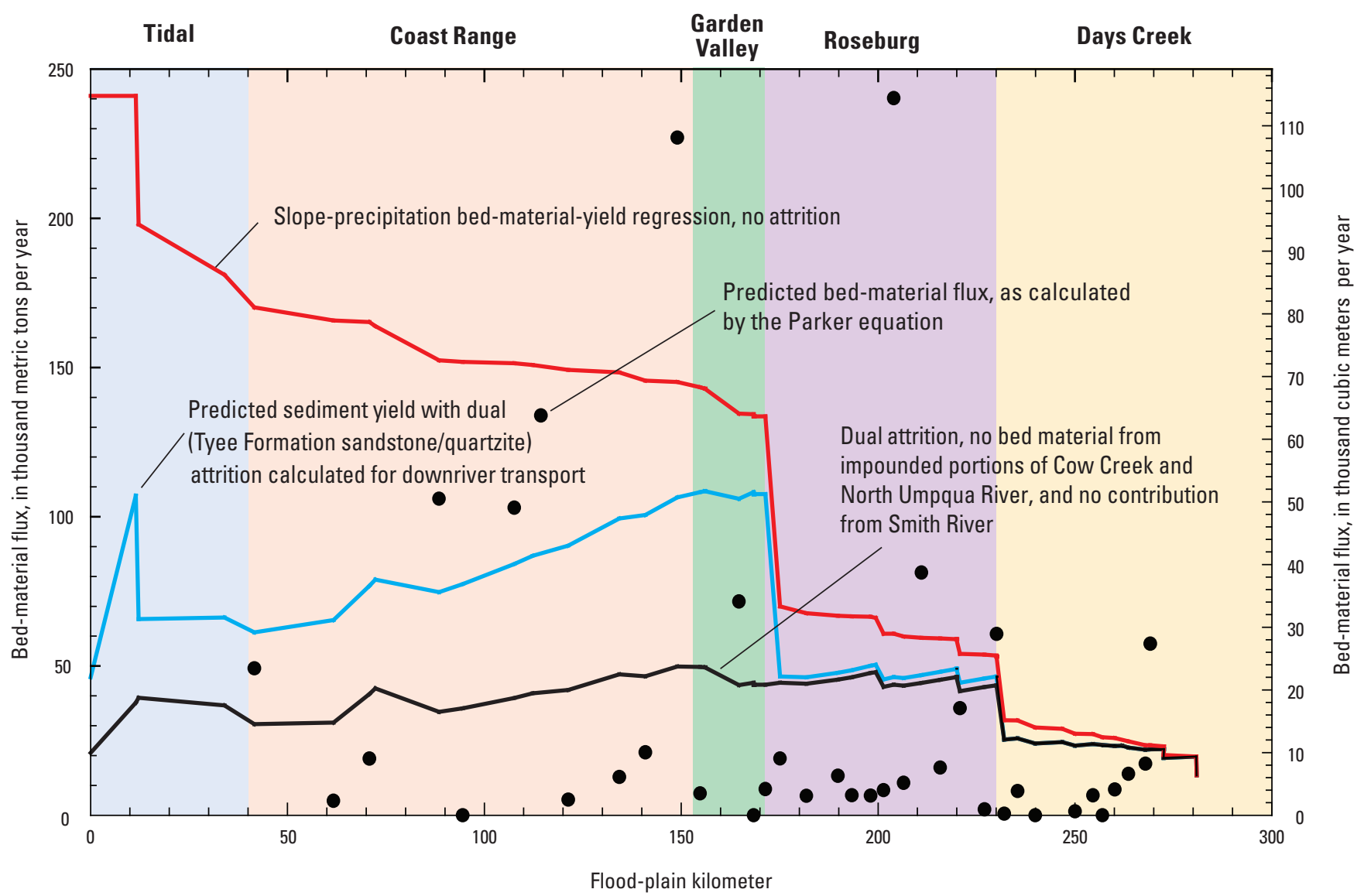

Figure 47. Predicted bed-material yield in the Umpqua River basin, Oregon, under different scenarios of attrition and tributary contribution.

Combining the empirical bed-material sediment yield estimates with estimates of downriver attrition rates and the impoundments of Cow Creek, North Umpqua River, and Smith River gives an overall prediction of bed-material flux along the Umpqua and South Umpqua Rivers (fig. 47). Flux rates generally increase within the Days Creek and Roseburg reaches from approximately 13,400 metric tons/yr at the upstream end of the Days Creek reach to nearly 50,000 metric tons/yr within the Roseburg and Coast Range reaches.

Downstream, predicted flux rates diminish as attrition exceeds input of bed material, gradually diminishing to 30,00040,000 metric tons/yr at the entrance to the Tidal reach.

\section{Summary of Bed-Material Characterization and Transport}

Measurements of bed-material sediment at 51 sites in the Umpqua River study area provide a basis for characterizing longitudinal patterns in bar texture and also support calculations of transport capacity (table 9). Surface particle sizes at 41 bars on the South Umpqua and main stem Umpqua Rivers indicate a general downstream fining of surface bar texture, with median grain size diminishing from about $100 \mathrm{~mm}$ in the Days Creek reach to less than $50 \mathrm{~mm}$ in the Coast Range reach (table 9; fig. 37). Subsurface grain sizes diminished much less, from median grain sizes of 20-40 mm in the Days Creek reach to about $15 \mathrm{~mm}$ in the Coast Range reach (fig. 37; table 9). Tributary bed material typically is finer than that in the main stem Umpqua River. 
Armoring ratios computed for 25 sites on the main stem Umpqua and South Umpqua Rivers range between 1.08 and 4.73 , with a mean value of 2.3 , which is consistent with overall conditions of excess transport capacity relative to bed-material supply. Armoring ratios on tributaries generally are lower; a value of 1.0 computed for Cow Creek indicates that for that stream, sediment supply may approximate or exceed transport capacity.

Clast lithologies assessed at each of the sampling sites document the persistence of felsic intrusive rocks (which originate in Klamath Mountains terrain) in the bed material. The much softer sedimentary rocks of the Coast Range terrain were either scarce or absent at most sites, which is consistent with the greater abundance of gravel bars in the Days Creek and Roseburg reaches compared to downstream reaches and the overall conclusion that Klamath Mountains terrain rock types are a major source of bed material for the Umpqua River.

Calculated bedload transport capacity for WYs 1952-2008 varies markedly temporally and spatially among 44 computation sites on the South Umpqua River and Umpqua River, and a single site on Cow Creek (figs. 40 and 41). Variation among the four applied transport equations is due primarily to differences in surface and subsurface sediment-size distributions among the sites and the minor differences in the equation forms. The largest discrepancies between the surface and subsurface-based equations are at armored bars, where the transport capacities computed by the subsurface-based equations can be 2-3 orders of magnitude greater than those computed using surface grain sizes (table 9 ).

Annual transport capacity calculated for individual sites ranges from essentially zero transport during low-flow years, such as 1977 and 2001, to as much as 600,000 metric tons/yr for high-flow years, such as 1964 and 1997. For the Umpqua Sand and Gravel Bar (FPKM 171.4), more than 50 percent of the total bed-material transport capacity for this 57 -year period occurred over a total of just 80 days. There is also considerable spatial variation, as computed transport capacity values throughout the study area span more than six orders of magnitude. Armored and rarely mobilized sites such as Maupin Bar (FPKM 94.5) have little or no transport capacity in most years, whereas other highly mobile sites, such as Willis Creek Bar and Myrtle Creek Bridge Bar (FPKM 204 and 219.9), have calculated mean annual transport capacities of 100,000-300,000 metric tons. With the exception of the large bars at the mouth of Cow Creek, many of the largest bar complexes in the study area are in areas of decreasing transport capacity.
Most sites with high calculated annual transport capacities are small patches of gravel deposited in the lee of bedrock rapids (fig. 16) and likely are not representative of overall reach conditions. The wide-ranging variability in estimated transport capacities over time and between sites illustrates the highly nonlinear dependence of bed-material transport on key parameters of grain size, slope, and discharge. Sensitivity trials, combined with field observations, show that although some of the spatial variations in transport capacity may arise from uncertainties in calculation parameters, most of the variation for the Umpqua River system probably results from the diversity of bar types and the supply-limited character of the Umpqua River.

Considering the limitations of the equation-based approach to the Umpqua River system, these calculations probably are not a reliable means of estimating actual bedload fluxes; nonetheless, given the range of calculations and associated bar mobilities ( figs. 40 and $\underline{42}$ ), we judge that the overall transport capacity along the South Umpqua and Umpqua Rivers is probably less than 25,000 metric tons/yr, a value consistent with the minimum bed-material transport rates of 2,810 to 30,600 metric tons during WYs 2002-08 determined from the site-specific gravel bar surveys.

A second approach to estimating rates of bed-material transport in the Umpqua River basin is an analysis of regional measurements of bed-material yields. This analysis indicates that basin attributes such as slope, drainage density, and precipitation correlate with bed-material yield. The correlation between bed-material yield and the product of basin slope and precipitation is most applicable to the Umpqua River basin. Application of this sediment-yield relation in conjunction with (1) estimates of particle attrition, and (2) the effects of dams and tidal influence, which markedly reduce or eliminate bedmaterial supply from the North Umpqua River, Smith River, and part of the Cow Creek basin, results in flux rates that generally increase in the Days Creek and Roseburg reaches, from approximately 13,400 metric tons/yr at the upstream end of the Days Creek reach to nearly 50,000 metric tons/yr within the Roseburg and Coast Range reaches. Downstream, predicted flux rates diminish as attrition exceeds input of bed material, gradually diminishing to 30,000-40,000 metric tons/yr at the entrance to the Tidal reach.

The bedload transport capacity estimates are broadly consistent with the bed-material yield analysis and sitespecific surveys at instream gravel mining sites along the Roseburg and Days Creek reaches (tables 11 and 12) which indicate local bed-material flux rates of up to 30,600 metric tons/yr in high-flow years, but less than 10,000 metric tons/yr in more typical years. 

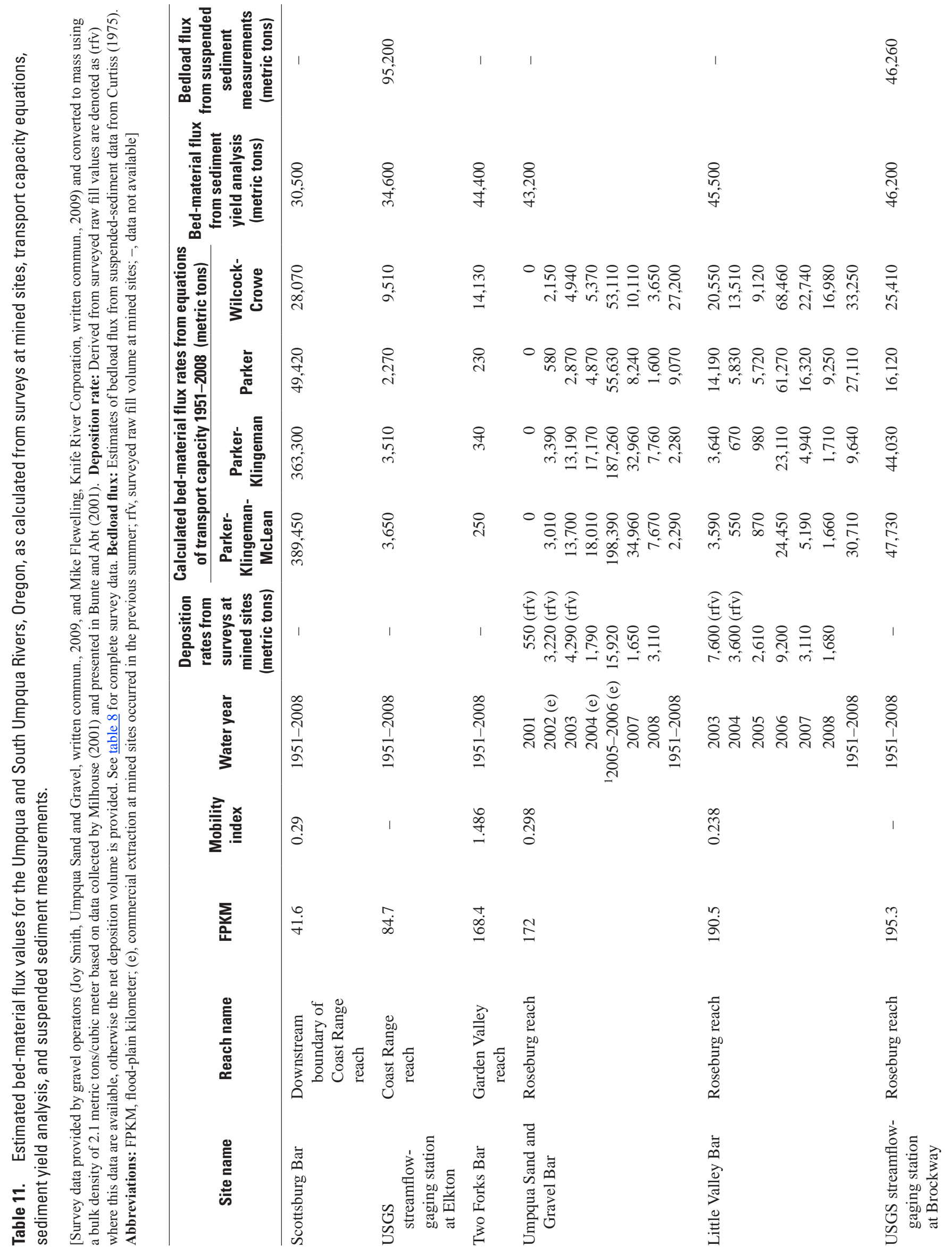

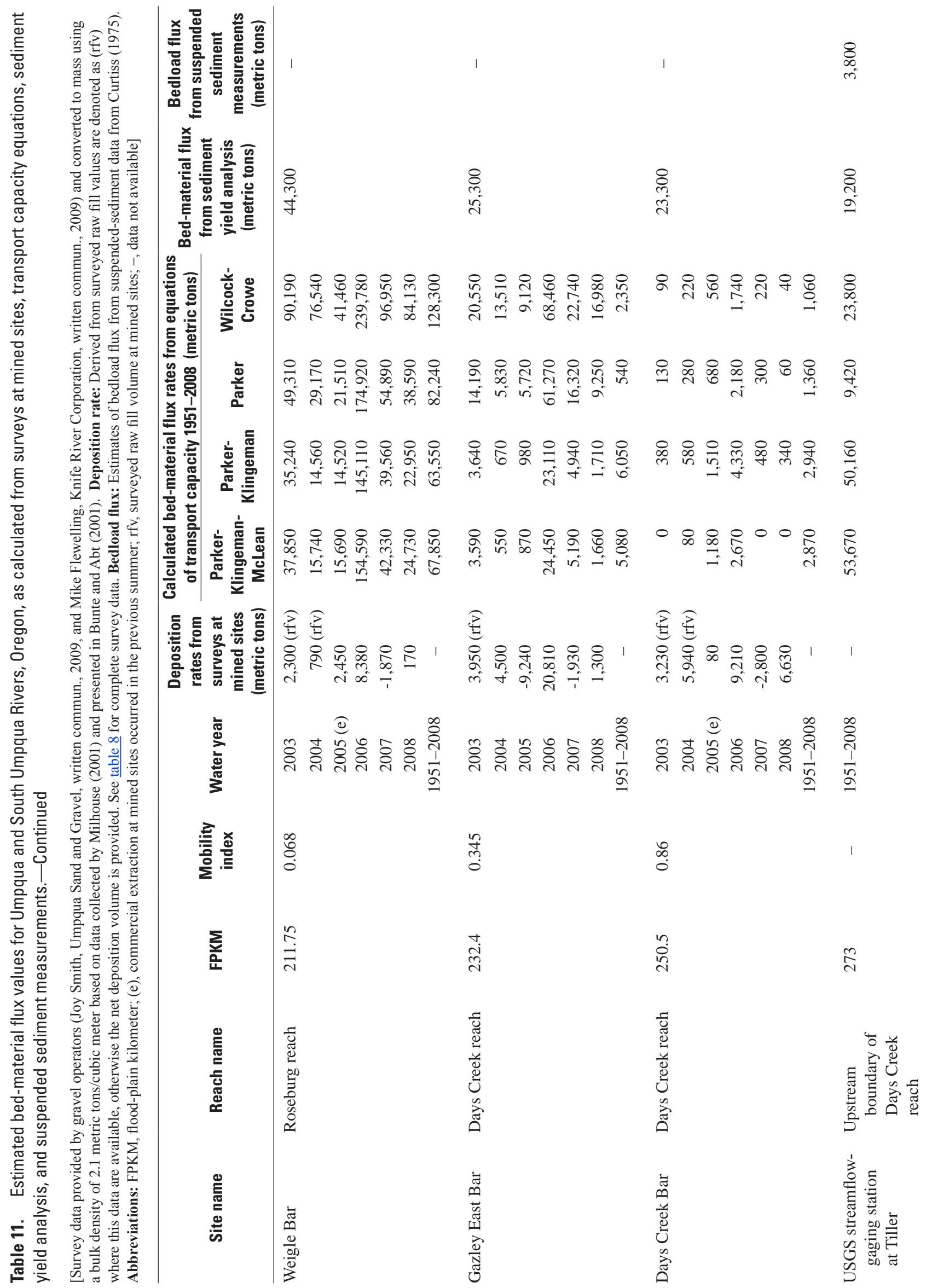

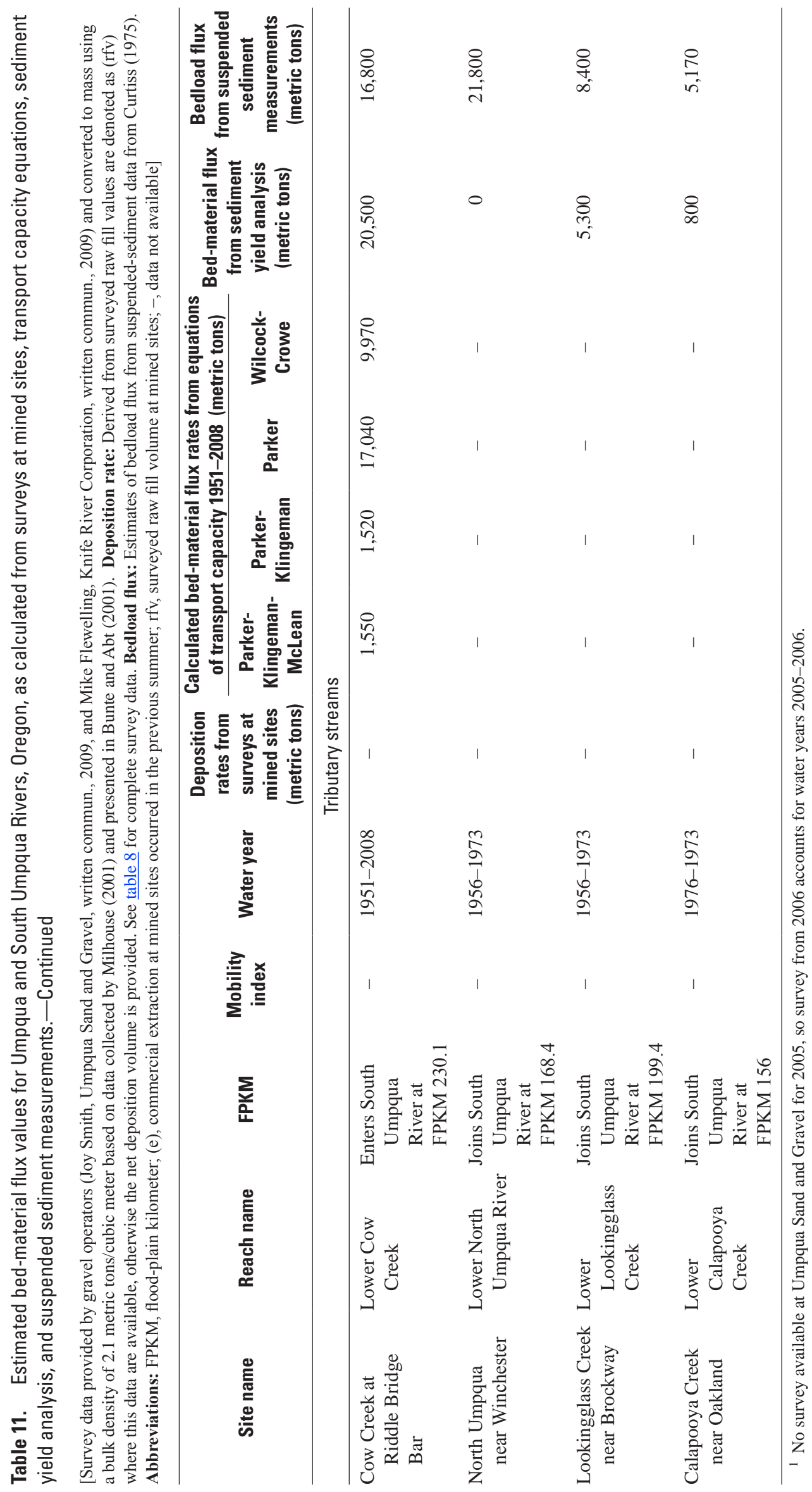
Table 12. Reach-segregated bed-material flux values for the Umpqua and South Umpqua Rivers, as calculated from surveys at mined sites, transport capacity equations, sediment yield analysis, and suspended-sediment measurements.

[Bedload flux: Estimates of bedload flux from suspended-sediment data from Curtiss (1975). Abbreviaton: FPKM, flood-plain kilometer; -, no data]

\begin{tabular}{|c|c|c|c|c|c|c|c|c|}
\hline \multirow[b]{2}{*}{ Reach Name } & \multirow[b]{2}{*}{ FPKM } & \multirow{2}{*}{$\begin{array}{c}\text { Range of } \\
\text { surveyed fill } \\
\text { volumes and } \\
\text { net deposition } \\
\text { rates }\end{array}$} & \multicolumn{4}{|c|}{$\begin{array}{l}\text { Calculated median transport capacity value 1951-2008 } \\
\text { (metric tons) }\end{array}$} & \multirow{2}{*}{$\begin{array}{l}\text { Bed-material } \\
\text { flux from } \\
\text { sediment } \\
\text { yield analysis } \\
\text { (metric tons) }\end{array}$} & \multirow{2}{*}{$\begin{array}{l}\text { Bedload flux from } \\
\text { suspended sediment } \\
\text { measurements } \\
\text { (metric tons) }\end{array}$} \\
\hline & & & $\begin{array}{c}\text { Parker- } \\
\text { Klingeman- } \\
\text { McLean }\end{array}$ & $\begin{array}{l}\text { Parker- } \\
\text { Klingeman }\end{array}$ & Parker & $\begin{array}{l}\text { Wilcock- } \\
\text { Crowe }\end{array}$ & & \\
\hline Coast Range reach & $40-152$ & - & 56,440 & 53,740 & 20,280 & 24,165 & $30,500-49,800$ & 195,200 \\
\hline Garden Valley reach & $152-169$ & - & 35,115 & 34,265 & 39,625 & 81,855 & $43,600-49,700$ & ${ }^{2} 68,060$ \\
\hline Days Creek reach & $231-275$ & $80-20,810$ & 4,450 & 4,400 & 7,585 & 12,260 & $19,200-25,800$ & ${ }^{4} 3,800$ \\
\hline
\end{tabular}

${ }^{1}$ From Elkton gaging station.

${ }^{2}$ Sum of Brockway and North Umpqua gaging stations.

${ }^{3}$ From Brockway gaging station.

${ }^{4}$ From Tiller gaging station.

\section{Summary and Conclusions}

This study, done in cooperation with the U.S. Army Corps of Engineers, assessed spatial and temporal trends in channel change and bed-material transport for $350 \mathrm{~km}$ of alluvial and semi-alluvial river channel in the Umpqua River basin. Basin network structure and channel geomorphology led to subdivision of the river system into six contiguous analysis reaches. The North Umpqua reach includes $47 \mathrm{~km}$ of channel extending upstream of the North Umpqua River confluence with the South Umpqua River. The Days Creek reach encompasses $47 \mathrm{~km}$ of the South Umpqua River from the upstream extent of the study area near Tiller, Oregon, to the Cow Creek confluence. The Roseburg reach continues $76 \mathrm{~km}$ downstream of Cow Creek to the South Umpqua River confluence with the North Umpqua River. The Garden Valley reach contains the Umpqua River for the $19 \mathrm{~km}$ from the confluence of the North Umpqua and South Umpqua Rivers to the entrance of the Coast Range, from where the Coast Range reach of the Umpqua River extends another $116 \mathrm{~km}$ downstream to the head of tide near Scottsburg, Oregon. The much lower gradient and partly estuarine Tidal reach encompasses the final $45 \mathrm{~km}$ of river channel and through Winchester Bay to the Pacific Ocean at Reedsport. These reaches have distinct physiographic and bed-material transport conditions, as well as distinct histories of instream gravel mining, thereby providing an efficient analysis and discussion framework.

The findings reported here draw largely upon two components: (1) historical analyses, including detailed mapping of the active channel using aerial photographs and repeat surveys, to document spatial and temporal changes in channel morphology and bed-material storage and (2) quantitative investigation of the bed-material flux through the study reaches. These analyses provide a basis for understanding the recent history of the active channel and also allow for inferences regarding the spatial and temporal variation of production, fluxes, and routing of bed material through the study reaches.

\section{Primary Findings}

The overall character of the Umpqua River reflects its geologic history. For the past 10,000 years, the overall trend for fluvial reaches of the Umpqua River has been incision, where transport capacity has exceeded the supply of coarse bed-material sediment, as indicated by abundance of exposed bedrock in and flanking the active channel throughout the study area. This channel characteristic, as well as the sparse gravel cover, was specifically noted by 19th and 20th-century Euro-American explorers. Repeat mapping from multiple aerial-photograph sets spanning 1939-2009 shows that the fluvial reaches of the Umpqua, South Umpqua, and North Umpqua Rivers flow within largely stable, single-thread channels of bedrock or coarse boulder and cobble substrates. Coarse bed-material sediment locally mantles the bedrock, forming shallow bars in and flanking the low-flow channel, whose position and overall size are dictated primarily by valley geometry rather than channel migration processes.

Gravel bars have historically been most abundant on the South Umpqua River within the Roseburg and Days Creek reaches, where there has been as much as 1.3-4 times the area of gravel bars per unit length of stream (approximately 12.7-31.8 $\mathrm{m}^{2} / \mathrm{m}$ ) compared with the Coast Range and Garden Valley reaches (where specific bar area has ranged from 5.0 to $13.7 \mathrm{~m}^{2} / \mathrm{m}$ ). Although bedrock rapids and channelflanking bedrock shoals are common features throughout the study area, they are most abundant along the Umpqua and 
North Umpqua Rivers, where 2005 aerial photographs show 3-5 times more exposed bedrock (by area) than mapped gravel. Most of the gravel in the study area is stored in large bars with areas greater than $20,000 \mathrm{~m}^{2}$, many of which apparently become active areas of bed-material transport only during exceptionally large floods, such as the December 1964 flood. Although many numerous smaller gravel patches (less than 2,000 $\mathrm{m}^{2}$ ) flank the river at the heads of rapids and immediately downstream, these smaller depositional zones account for less than 6 percent of the total mapped gravel in the study area in 2005.

The abundance of gravel bars along the lower South Umpqua River most likely results from Klamath Mountains source areas underlying much of the South Umpqua River basin. The tectonically deformed and metamorphosed Mesozoic rocks of the Klamath Mountains terrain, together with its steep slopes and dense stream network, enhance production and delivery of bed material to the South Umpqua River. High bed-material fluxes from this terrain have been documented for the Chetco River (Wallick and others, 2010) and Smith River (MFG, Inc. and others, 2006) to the south. Additionally, clasts from this terrain are probably more resistant to abrasion than bed material from the High Cascade and Western Cascade terrains, and consequently are a persistent component of Umpqua River bed material as far downstream as the Tidal reach. Cow Creek, a large tributary draining Klamath Mountains terrain, probably is a major supplier of gravel to the South Umpqua River, judging from the extensive gravel deposits near its mouth, the increased abundance of bars downstream of its confluence, and the low armoring ratio of bars within Cow Creek. Historically, several Klamath Mountains tributaries, including Cow Creek, Myrtle Creek, and Lookingglass Creek, were subject to extensive placer mining, which may have further enhanced sediment output from these streams, although historical photographs of the Roseburg reach do not indicate significantly greater gravel volumes during the early 20th century.

Bed-material sediment from Cascade Range streams originates mainly in the Western Cascades, because the much younger lava flows of the High Cascades are highly porous and have little capacity for sediment transport. Although the Western Cascades terrain yields more bed-material sediment than the High Cascades terrain, sediment production from the Western Cascades probably is small compared to that from Klamath Mountains terrain as evidenced by: (1) the North Umpqua reach, which exclusively drains the Cascade Range, had less than one-half of the gravel bars per unit stream length in 1939 than the South Umpqua reaches, and (2) the South Umpqua River upstream of the Days Creek reach drains only the Western Cascades terrain, and unlike the more gravel-rich lower reaches downstream of Klamath Mountains terrain tributaries, the river within the Western Cascades terrain is a narrow bedrock stream with boulder-dominated rapids and few gravel bars.
Farther downstream of its confluence with the South Umpqua River, sedimentary rocks supplied to the main stem Umpqua River by Coast Range tributaries are highly erodible, and although this region produces high suspended-sediment loads (for example, Beschta [1978]), bed-material clasts from these geologic units disintegrate readily. Therefore, although the terrain of Klamath Mountains comprises only 21 percent of the Umpqua River basin, it probably supplies a disproportionately large amount of bed-material sediment to the channel system. Further, the importance of this terrain to total basinwide sediment production is even larger because of the effects of dams on sediment transport in the North Umpqua River.

The primary observation from the repeat channel mapping and surveys is the overall stability of the Umpqua River planform. All fluvial reaches showed little change in sinuosity or channel width throughout the 70-year analysis timeframe, mainly because of lateral and vertical bedrock control. Consistent with this, repeat stage measurements at USGS streamflow-gaging stations show only local areas of slight channel deepening (on the order of 0.1-0.2 m), some of which may be associated with bedrock erosion.

The main temporal trend evident from repeat channel mapping from aerial photographs is a 29-percent decrease in the area of mapped gravel bars between 1939 and 2005. Most of this decrease was between 1967 and 2005, and was partly due to vegetation colonization on formerly active, upper bar surfaces, converting some of these high bar surfaces to floodplain. Also important was erosion of lower elevation bars to bedrock, particularly for the Coast Range and Garden Valley reaches. The decrease in mapped gravel bar area probably resulted from a combination of factors, including decreasing peak flows, gravel extraction, and dam construction. Several unregulated tributary streams, as well as the South Umpqua River gaging station at Brockway, show significant trends of decreasing peak flows since the 1950 s, which is probably due mainly to decadal-scale climate cycles. Because three of the five streams that show this trend drain Klamath Mountains terrain, even small decreases in peak flows on these tributaries may have a disproportionate effect on overall gravel transport in the study area. The cumulative effects of instream gravel extraction in recent decades likely also affects bed-material storage in the active channel because mined volumes in some years probably constituted a substantial portion of the overall gravel flux.

For the North Umpqua River, the 59-percent decrease in gravel between 1967 and 2005 is probably due to a combination of trapping of bed material by hydropower dams constructed in 1952-55 and climate-driven decreases in peak flows, as detected for the gaging station at Winchester. For this reach, decreased gravel bar area has led to much more exposure of active channel bedrock. 
Although the overall trend was of decreasing bar area, many bars have episodically grown, mainly as a consequence of large floods. This is particularly the case for the major flood of December 1964, which had an annual exceedance probability of about 1 percent. Total bar area throughout the fluvial reaches increased by more than 11 percent between 1939 and 1967, which probably is attributable mainly to the 1964 flood. Evident in the 1967 photographs are (1) removal of vegetation and bed-material deposition on upper bar surfaces, and (2) bed-material deposition extending the margins of low-elevation bars into areas mapped as water in 1939. Later but smaller floods in December 1996 and December 2005 resulted in smaller increases in bar area, but these increases have been offset by erosion and bar diminishment during intervening and subsequent years.

Bed-material flux was estimated for fluvial reaches of the Umpqua and South Umpqua Rivers by two independent approaches, supplemented by bed-material recruitment measurements at six sites of past gravel mining and by earlier measurements of suspended-sediment transport. Bed-material transport capacity estimates at 44 sites throughout the South Umpqua and main stem Umpqua Rivers for the period 1951-2008 result in transport capacity estimates that vary spatially and temporally. The temporal variations relate to flow history, with most transport associated with large peak flows. The diminishment in peak discharges over the last three decades, at least partly to climate cycles, has led to an overall temporal trend of reduced gravel transport.

The even wider spatial variations in calculated bedmaterial transport rates reflect the more fundamental difficulty of applying equations of bed-material transport capacity to a supply-limited river, where bar textures chiefly reflect local hydraulics rather than reach-scale supply conditions. Nevertheless, the transport capacity values should provide an indication of maximum possible bed-material transport rates; reach-averaged median transport capacity values calculated by the bed-material surface-based equations of Parker (1990a, 1990b) and Wilcock-Crowe (2003) equations for 1951-2008 yields a transport capacity of 7,000-27,000 metric tons/yr for the South Umpqua River and 20,000-81,000 metric tons/ yr for the main stem Umpqua River upstream of the head of tide (tables 11 and 12). The values of bed-material transport capacity values for the intermediate mobility sites, generally ranging between 500 and 20,000 metric tons/yr as predicted by the Parker (1990a, 1990b) equation, may be the best estimate for actual bed-material transport rates, although confidence in this assessment would be bolstered substantially by actual transport measurements.

These estimates of bed-material transport capacity are broadly consistent with an empirical bed-material yield analysis developed from regional bed-material transport measurements. The most satisfactory regional relation predicts bed-material yield as a function of source area slope and precipitation (fig. 43). Adopting this relation in conjunction with estimates of in-channel attrition, results in predicted bed-material fluxes of as much as 25,000 metric tons/yr on the
Days Creek reach, increasing to nearly 50,000 metric tons for the Roseburg, Garden Valley, and Coast Range reaches, but then decreasing to approximately 30,000 metric tons/yr at the entrance to the Tidal reach.

Both of these approaches - the transport capacity estimates and the regional bed-material sediment yield analysis - give results consistent with site surveys at individual bars within the Days Creek and Roseburg reaches. These surveys indicate minimum local bed-material flux rates of up to 30,600 metric tons/yr in high-flow years, but more typically less than 10,000 metric tons/yr.

The two approaches adopted by this study give estimates less than those predicted by Curtiss (1975) from suspendedsediment transport measurements made during 1956-1973. By applying an assumed bedload transport ratio to measured suspended-sediment loads, the Curtiss (1975) analysis predicts bedload transport rates of 8,400 metric tons/yr at Tiller, near the upstream end of the Days Creek reach at FPKM 273; 46,000 metric tons/yr at the Brockway streamflow measurement site on the South Umpqua River within the Roseburg reach near FPKM 195.3; and 160,000 metric tons/ $\mathrm{yr}$ at the Elkton measurement site on the main stem Umpqua River in the Coast Range reach at FPKM 72.1. Although these bed-material transport values for the Days Creek and South Umpqua reaches are slightly higher than those we infer from the sediment yield and capacity analyses, they are within realistic uncertainty bounds. The estimate of 160,000 metric tons/yr of bedload at the Elkton measurement site on the main stem Umpqua River greatly exceeds likely bed-material transport rates for this reach as estimated from the capacity and yield analyses, and is almost certainly high as a result of substantially elevated suspended loads derived from Coast Range sedimentary rocks, which produce little bed material.

In consideration of all these analyses, together with the depositional volumes measured by individual gravel bar surveys, we judge that the actual bedload flux in most years is probably less than 25,000 metric tons/yr in the Days Creek and Roseburg reaches, although Cow Creek probably adds substantial bed material to the South Umpqua River at its confluence. Bed-material transport in the Garden Valley and Coast Range reaches may be similar or slightly less because of bed-material attrition exceeding tributary addition. For comparison, the estimated annual volume of commercial gravel extraction from the South Umpqua River was 9,260 metric tons in 2001, 610 metric tons in 2003, and 36,570 metric tons in 2004, based on data supplied by the two main operators in the South Umpqua River-which indicates that historical instream gravel extraction may have been a substantial fraction of the total bed-material flux in the Umpqua River system.

The Tidal reach has a distinctly different morphologic character and transport regime. The Umpqua River along the Tidal reach contains the largest bars in the study area, particularly at the expansive valley bottom near the confluence of the Smith River. These bars are mainly composed of sand and mud, contrasting with the gravel bars upstream. 
Commercial dredging has historically focused on the section between the Smith River confluence and upstream to the head of tide at FPKM 40, where there are few bars and repeat surveys show persistent channel deepening even in areas that had not been mined for several years.

Like other coastal streams in Oregon, the lower Umpqua River has been strongly affected by the $130 \mathrm{~m}$ of sea-level rise after the culmination of the last maximum glacial period 18,000 years ago, resulting in long-term aggradation and trapping of bed material and suspended coarse sand transported from upstream. Consequently, it is unlikely that substantial bed material from the upstream fluvial reaches (and the upper Smith River) is transported into the Pacific Ocean. The long Tidal reach (and lack of graded profile to the Pacific Ocean mouth) is evidence that upstream sediment supply has not kept pace with Holocene sea level rise inundating the lower Umpqua River valley.

The sediment yield analysis indicates that about 30,000-40,000 metric tons of bed-material sediment enters the Tidal reach annually, but bed-material accumulation within the lower Tidal reach may be substantially greater, because much of the sand transported in suspension upstream is likely transported as bedload in the Tidal reach due to the lower gradients. Consequently, while annual commercial instream mining averaged 140,000 $\mathrm{m}^{3}$ annually during 1949-2002, this volume is not indicative of bed-material transport rates in the upstream fluvial reaches because much of this material probably entered the Tidal reach as sand transported as suspended load from the upstream reaches.

\section{Implications Regarding Future Trends and Monitoring Strategies}

For a mixed bedrock and alluvial river such as the Umpqua River, the physical character of the channel is mainly the result of its geologic history and physiography. Throughout the Holocene, transport capacity has exceeded the supply of bed-material sediment, causing the Umpqua River to incise through Pleistocene valley fill and bedrock, resulting in a modern channel that flows mostly on bedrock. The character of individual bars is highly variable and depends on the history of flow and sediment transport, time lags involved in eroding and redepositing sediment, and other local and drainage-basinscale disturbances that might affect the channel directly or indirectly.

Although many factors influence the abundance and character of Umpqua River gravel bars, the decreases in bar areas observed on all of the fluvial reaches between 1967 and 2005 will likely continue if future gravel removal exceeds bed-material influx. Continued decreases in bar area may also be accompanied by the coarsening of low-elevation active bars that currently have low armoring ratios. In the absence of future mining, bar building will probably be greatest in the lower Days Creek reach and throughout the Roseburg reach, as this area has historically had the greatest concentration of gravel bars because of the high influx of bed-material sediment from tributaries draining the Klamath Mountains terrain.

However, even prior to gravel extraction and dam construction, transport capacities throughout the Umpqua River study area were much greater than sediment supply, so bar building may proceed slowly following cessation of gravel extraction, and the rate of bar growth will depend on the timing and magnitude of peak flows and the sediment influx accompanying these floods. Although gravel augmentation on the North Umpqua River began in 2004 (Stillwater Sciences, 2006), this additional gravel is not likely to have a substantial effect on bar area in the lower North Umpqua River and main stem Umpqua River because the total augmentation volume is small relative to the long-term gravel deficit introduced by the hydropower dams (based on data provided by PacifiCorp, 2002 and Stillwater Sciences, 2006).

To better understand variation in bed-material storage under different management scenarios, actual bed-material influx to the Umpqua River study reaches must be accurately quantified. However, it is difficult to characterize bed-material fluxes in gravel-rich settings, and even more so for the supplylimited Umpqua River, where bar characteristics and sediment transport are highly variable. Improving our understanding of bed-material fluxes on the Umpqua River will require a variety of independent methodologies, bolstered by highresolution datasets. The approaches that will potentially be most useful for future characterization of bed-material storage in the Umpqua River study area include (1) the application of transport capacity equations, similar to the methodology used here, but updated using a detailed hydraulic model and up-todate bar texture information, and (2) direct measurements of bedload transport, which could be difficult to obtain and interpret, but as part of a sustained monitoring program would significantly aid in characterizing bed-material fluxes across a range of flows.

A detailed hydraulic model, along with several key datasets, would support these approaches and form the basis for a future adaptive management program. The nonlinear response of calculated transport capacities to variation in grain size and slope indicates the need for accurate, detailed data describing Umpqua River bar textures and hydraulics. The hydraulic model encompassing the South Umpqua and Umpqua Rivers above the head of tide could be developed from LIDAR topography, and bathymetric surveys would provide a more accurate method of calculating energy slope under a variety of discharge scenarios. At a minimum, the modeling approach would entail a 1D hydrodynamic model with closely spaced cross sections to characterize the highly variable channel. Ideally, the approach would entail a blend of both 1D and 2D models so that the complex hydraulics at large key bars in sharp bends (such as Maupin Bar and Days Creek Bar) are accurately characterized. Such a modeling framework could be used to more accurately calculate energy slope under a variety of discharge scenarios, enabling better understanding of transport conditions and refining our overall understanding of longitudinal patterns in bed-material transport. A detailed 
hydraulic model, if coupled with a spatially discrete sediment transport model, could also be used to simulate morphological changes to the channel bed under different management and flood scenarios.

If repeated at regular intervals or following large floods, the LIDAR and bathymetric surveys underlying the hydraulic model would provide a comprehensive basis for evaluating future changes to channel morphology and bar topography. Such data, combined with detailed measurements of bar thickness, could also be used to calculate volumetric sediment flux and deposition rates throughout the study area (similar to a morphology-based approach applied on alluvial rivers). Because the channel is primarily underlain by bedrock and is in many places shallow, the bathymetric survey could consist of depth soundings along the centerline of deep pools, as the LIDAR acquired at low flows would provide an adequate approximation of bed elevation in rapids. Future monitoring could also incorporate sampling of bar textures at regular intervals (perhaps every $2-5$ years, or following a flood of a certain magnitude) in order to improve our transport capacity calculations. Textural information, combined with repeat mapping of vegetation densities from aerial photographs would also aid in evaluating temporal evolution of bars in response to different management scenarios and floods.

\section{Acknowledgments}

The framework for this study was established with the guidance of Judy Linton of the Portland District of the U.S. Army Corps of Engineers. Information on past gravel mining, access to measurement sites and detailed topographic surveys of mining sites were provided by Umpqua Sand and Gravel, Knife River Corporation, and IE Engineering. Joy Smith and Kelly Guido of Umpqua Sand and Gravel, and Mike Flewelling of Knife River Corporation were especially responsive to our data requests. Chris Lidstone, Lidstone and Associates, supplied reports and surveys from the historically dredged area of the Umpqua River estuary, and provided thoughtful feedback during both phases of this study. Peter Klingeman, Professor Emeritus, Oregon State University, provided instructive comments and observations concerning sediment transport in the Umpqua River basin and reviewed this manuscript. Janine Castro, U.S. Fish and Wildlife Service lent her expertise to both phases of this study by providing helpful comments regarding our study approach and numerous datasets and documents regarding Umpqua River sediment issues. Chuck Wheeler, NOAA Fisheries provided historical data, helpful comments and a field tour of the Umpqua River Basin. Adam Stonewall, USGS Oregon Water Science Center, assisted with the specific gaging station analysis. Jeff Coe, USGS Landslide Hazards Program, provided LIDAR datasets of the Oregon Coast Range. Chauncey Anderson, USGS Oregon Water Science Center, shared resources, reports, and photographs of the Umpqua River basin. Mikeal Jones of the U.S. Forest Service provided helpful comments following the preliminary Phase I study of this report. Field assistance was provided by Dan Polette, Norman Buccola, Esther Duggan, Rachel Peavler, and Tara Chestnut, all of the USGS Oregon Water Science Center. Steve Sobieszczyk, USGS Oregon Water Science Center, assisted with the Phase I version of this study and with field measurements. Tana Haluska, USGS Oregon Water Science Center, contributed to GIS analyses and metadata preparation. Bedload transport modeling was facilitated by assistance with the Bedload Assessment for Gravel-bed Streams (BAGS) software by John Pitlick, Yantao Cui, and Peter Wilcock.

\section{References Cited}

Aalto, R., Dunne, T., and Guyot, J.L., 2006, Geomorphic controls on Andean denudation rates: The Journal of Geology, v. 114, p. 85-99.

Ambers, R.K., 2001, Using the sediment record in a western Oregon flood-control reservoir to assess the influence of storm history and logging on sediment yield: Journal of Hydrology, v. 244, p. 181-200.

Andrews, D.J., and Buckman, R.C., 1987, Fitting degradation of shoreline scarps by a nonlinear diffusion model: Journal of Geophysical Research, v. 92, p. 12857-12867.

Atwood, Kay, 2008, Chaining Oregon, Surveying the public lands of the Pacific Northwest, 1851-1855: Granville, Ohio, The McDonald and Woodward Publishing Company, 267 p.

Bakke, P.D., Basdekas, P.O., Dawdy, D.R., and Klingeman, P.C., 1999, Calibrated Parker-Klingeman model for gravel transport: Journal of Hydraulic Engineering, v. 125, p. 657-660.

Beckham, S.D., 1986, Land of the Umpqua, a history of Douglas County, Oregon: Roseburg, Oreg., Douglas County Commissioners, 285 p.

Benda, Lee, and Dunne, Thomas, 1997, Stochastic forcing of sediment supply to channel networks from landsliding and debris flow: Water Resources Research, v. 33, no. 12, p. 2849-2863.

Beschta, R.L., 1978, Long-term patterns of sediment production following road construction and logging in the Oregon Coast Range: Water Resources Research, v. 14, p. 1011-1016.

Bowling, L.C., Storck, Pascal, and Lettenmaier, D.P., 2000, Hydrologic effects of logging in western Washington, United States: Water Resources Research, v. 36, no. 11, p. 3223-3240. 
Buffington, J.M., and Montgomery, D.R., 1999, Effects of sediment supply on surface textures of gravel-bed rivers: Water Resources Research, v. 35, no. 11, p. 3523-3530.

Bumbaco, K.A. and Mote, P.W., 2010, Three different flavors of drought in the Pacific Northwest: Journal of Applied Meteorology and Climatology, v. 49, p. 2058-2068, doi:10.1175/2010JAMC2423.1.

Bunte, Kristin, and Abt, S.R., 2001, Sampling surface and subsurface particle-size distributions in wadable gravel and cobble-bed streams for analyses in sediment transport, hydraulics, and streambed monitoring: U.S. Department of Agriculture, Forest Service, Rocky Mountain Research Station, General Technical Report RMRS-GTR-74, 428 p.

Bureau of Land Management, 2009 Land status and cadastral records viewer, Willamette meridian-Oregon and Washington states: accessed 2009 at http://www.blm.gov/or/ landrecords/survey/ySrvy1.php.

Bureau of Land Management and U.S. Forest Service, 2009, GeoCommunicator, National integrated land system: Bureau of Land Management Land Survey Information System website: accessed December 2009 at http://www. geocommunicator.gov/GeoComm/lsis home/home/index. shtm.

CH2M Hill, 1971, Umpqua River gravel study for Umpqua River navigation company: Corvallis, Oregon, 29 p.

Church, Michael, 1988, Floods in cold climates, in Baker, V.R., Kochel, R.C., and Patton, P.C., eds., Flood geomorphology: New York, Wiley, p. 205-229.

Church, Michael, and Jones, D., 1982, Channel bars in gravelbed rivers, in Hey, R.D., Bathurst, J.C., and Thorne, C.R., eds., Gravel bed rivers: Chichester, England, John Wiley and Sons, p. 291-338.

Church, Michael, McLean, D.G., and Wolcott, D.F., 1987, River bed gravels: sampling and analysis, in Thorne, C.R., Bathurst, J.C., and Hey, R.D., eds., Sediment transport in gravel-bed rivers: Chichester, England, John Wiley and Sons, p. 43-88.

Collins, B.D., and Dunne, Thomas, 1989, Gravel transport, gravel harvesting, and channel-bed degradation in rivers draining the southern Olympic mountains, Washington, U.S.A.: Environmental Geology, v. 13, no. 3, p. 213-224.

Culling, W.E.H., 1960, Analytical theory of erosion: The Journal of Geology, v. 68, p. 336-344.

Culling, W.E.H., 1963, Soil creep and the development of hillside slopes: The Journal of Geology, v. 71, p. 127-161.

Curtiss, D.A., 1975, Sediment yields of streams in the Umpqua River basin, Oregon: U.S. Geological Survey Open-File Report, 1 plate with text.
Dana, J.D., 1849, Geology, United States exploring expedition during the years 1828, 1839, 1840, 1841, 1842, under the command of Charles Wilkes, U.S.N. [Volume X]: New York, Putnam, 756 p.

Dietrich, W.E., Kirchner, J.W., Ikeda, Hiroshi, and Iseya, Fujiko, 1989, Sediment supply and the development of the coarse surface later in gravel-bedded rivers: Nature, v. 340, no. 6230, p. 215-217.

Dietrich, W.E., and Smith, J.D., 1984, Bed load transport in a river meander: Water Resources Research, v. 20, no. 10, p. 1355-1380, doi: 10.1029/WE020i010p01355.

Diller, J.S., 1914, Mineral resources of southwestern Oregon: U.S. Geological Survey Bulletin 546, 147 p.

Douglas, D., 1914, Journal kept by David Douglas during his travels in North America 1823-1827, together with a particular description of thirty-three species of American oaks and eighteen species of Pinus, with appendices containing a list of the plants introduced by Douglas and an account of his death in 1834, published under the direction of the Royal Horticultural Society: London, William Wesley \& Son, 349 p.

Douglas, I., 1967, Man, vegetation, and the sediment yield of rivers: Nature, v. 215, p. 925-28.

Ferrari, R.L., 2001, Henry Hagg Lake 2001 Survey: Bureau of Reclamation, 17 p.

Geyer, N.A., 2003a, Lower North Umpqua River watershed assessment and action plan, July 2003: Roseburg, Oregon, Umpqua Basin Watershed Council, 203 p.

Geyer, N.A., 2003b, Lower South Umpqua River watershed assessment and action plan, July 2003: Roseburg, Oregon, Umpqua Basin Watershed Council, 189 p.

Geyer, N.A., 2003c, Middle South Umpqua River watershed assessment and action plan, July 2003: Roseburg, Oregon, Umpqua Basin Watershed Council, 187 p.

Geyer, N.A., 2003d, South Umpqua River watershed assessment and action plan, November 2003: Roseburg, Oregon, Umpqua Basin Watershed Council, p. 209.

Gilbert, G.K., and Murphy, E.C., 1914, The transportation of debris by running water: U.S. Geological Survey Professional Paper 86, 263 p.

Gomez, Basil, 1991, Bedload transport: Earth-Science Reviews, v. 31, no. 2, p. 89-132.

Gomez, Basil, and Church, Michael, 1989, An assessment of bed load sediment transport formulas for gravel bed rivers: Water Resources Research, v. 25, p. 1161-1186. 
Grant, G.E., and Wolff, A.L., 1990, Long-term patterns of sediment transport after timber harvest, Western Cascade Mountains, Oregon, USA, in Sediment and stream water quality in a changing environment, Vienna, August 1991, Proceedings: Vienna Symposium, p. 31-41.

Gurnell, A.M., 1997, Channel change on the River Dee meanders, 1946-1992, from the analysis of air photographs: Regulated Rivers—Research and Management, v. 13, p. 13-26.

Hicks, D.M., and Gomez, B., 2003, Sediment transport, in Kondolf, G.M., and Piegay, H., eds., Tools in fluvial geomorphology: Chichester, England, John Wiley and Sons, p. $425-461$.

Hicks, D.M., McSaveney, M.J., and Chinn, T.J.H., 1990, Sedimentation in proglacial Ivory Lake, Southern Alps, New Zealand: Arctic Alpine Research, v. 22, p. 26-42.

Hirano, M., 1968, A mathematical model for slope development: Journal of Geosciences, v. 11, p. 13-52.

Hooke, R.L., 2000, Toward a uniform theory of clastic sediment yield in fluvial systems: Geological Society of America Bulletin, v. 112, no. 12, p. 1778-1786, doi: 10.1130/0016-7606(2000)112<1778:TATUOC>2.0.CO;2.

Howard, A.D., 1998, Long profile development of bedrock channels: Interaction of weathering, mass wasting, bed erosion, and sediment transport, in Tinkler, K.J., and Wohl, E.E., eds., 1998, Rivers over rock—Fluvial processes in bedrock channels: American Geophysical Union Geophysical Monograph 107, p. 297-319.

Hughes, M.L., McDowell, P.F., and Marcus, W.A., 2005 [2006], Accuracy assessment of georectified aerial photographs-Implications for measuring lateral channel movement in GIS: Geomorphology, v. 74, p. 1-16.

Jefferson, Anne, Grant, G.E., Lewis, S.L., and Lancaster, S.T., 2010, Coevolution of hydrology and topography on a basalt landscape in the Oregon Cascade Range, USA: Earth Surface Processes and Landforms, v. 35, p. 803-816, doi: 10.1002/esp.1976.

Jones, B.E., and Stearns, H.T., 1930, Water-power resources of the Umpqua River and its tributaries, Oregon: U.S. Geological Survey Water-Supply Paper 636-F, p. 221-330.

Jones, J.A., and Grant, G.E., 1996, Long-term stormflow responses to clearcutting and roads in small and large basins, western Cascades, Oregon: Water Resources Research, v. 32, no. 4, p. 959-974.

Jones, J.A., and Grant, G.E., 2001, Comment on "Peak flow responses to clear-cutting and roads in small and large basins, western Cascades, Oregon": Water Resources Research, v. 37, no. 1, p. 179-180.
Kelsey, H.M., Coghlan, Mike, Pitlick, John, and Best, David, 1995, Geomorphic analysis of streamside landslides in the Redwood Creek basin, northwestern California, in Nolan, K.M., Kelsey, H.M., and Marron, D.C., eds., Geomorphic processes and aquatic habitat in the Redwood Creek basin, northwestern California: U.S. Geological Survey Professional Paper 1454, p. J1-J12.

Klingeman, P.C., 1973, Indications of streambed degradation in the Willamette Valley: Corvallis, Department of Civil Engineering, Oregon State University, Water Resources Research Institute Report WRRI-21, 99 p.

Komar, P.D., 1997, The Pacific Northwest coast—Living with the shores of Oregon and Washington: Durham, North Carolina, Duke University Press, 195 p.

Kondolf, G.M., 1994, Geomorphic and environmental effects of instream gravel mining: Landscape and Urban Planning, v. 28 , no. 2-3, p. 225-243.

Kondolf, G.M., 1997, Hungry water-Effects of dams and gravel mining on river channels: Environmental Management, v. 21, no. 4, p. 533-551.

Kondolf, G.M., Lisle, T.E., and Wolman, G.M., 2003, Bed sediment measurement, in Kondolf, G.M., and Piegay, H., eds., Tools in fluvial geomorphology: Chichester, England, John Wiley and Sons, p. 347-395.

Langbein, W.B., and Schumm, S.A., 1958, Yield of sediment in relation to mean annual precipitation: American Geophysical Union Transactions, v. 39, p. 1076-1084.

Lisle, T.E., and Madej, M.A., 1992, Spatial variation in armouring in a channel with high sediment supply, in Billi, P., and others, eds., Dynamics of Gravel-Bed Rivers: New York, John Wiley, p. 277-296.

Ma, Lina, Wells, R.E., Niem, A.R., Niewendorp, C.A., and Madin, I.P., 2009, Preliminary digital geologic compilation map of part of northwestern Oregon: Department of Geology and Mineral Resources Open-File Report O-0903.

Madej, M.A., 1995, Changes in channel-stored sediment, Redwood Creek, northwestern California, 1947 to 1980, in Nolan, K.M., Kelsey, H.M., and Marron, D.C., eds., Geomorphic processes and aquatic habitat in the Redwood Creek basin, northwestern California: U.S. Geological Survey Professional Paper 1454, p. O1-O27.

Magirl, C.S., Webb, R.H., and Griffiths, P.G., 2005, Changes in the water surface profile of the Colorado River in Grand Canyon, Arizona, between 1923 and 2000: Water Resources Research, v. 41, 10 p., W05021, doi:10.1029/2003WR002519. 
Markers, A.G.M., 2000, Footsteps on the Umpqua, Winterbotham, J., comp., Lebanon, Oregon, Dalton Press, 252 p.

Marshall, R.B., 1915, Profile surveys in 1914 in Umpqua River basin, Oregon: U.S. Geological Survey Water-Supply Paper 379, 7 p., 8 pls., map scale 1:31,680.

MFG, Inc., Graham Mathews and Associates, and Alice Berg and Associates, 2006, Assessment of the lower Smith River-Report prepared for County of Del Norte, Crescent City, California, 41 p.

Milhous, R.T., 1973, Sediment transport in a gravel-bottomed stream: Corvallis, Oregon State University, Ph.D. dissertation, 232 p.

Milhous, R.T., 2001, Specific weight and median size of the bed material of gravel and cobble bed rivers: Proceedings of the Seventh Federal Interagency Sedimentation Conference, March 25-29, 2001, Reno, Nevada.

Milliman, J.D., and Syvitski, J.P.M., 1992, Geomorphic/ tectonic control of sediment discharge to the ocean-The importance of small mountainous rivers: The Journal of Geology, v. 100, p. 525-544.

Mount, N.J., and Louis, J., 2005, Estimation and propagation of error in the measurement of river channel movement from aerial imagery: Earth Surface Processes and Landforms, v. 30, no. 5, p. 635-643.

Mueller, E.R., Pitlick, John, and Nelson, J.M., 2005, Variation in the reference shields stress for bed load transport in gravel-bed streams and rivers: Water Resources Research, v. 41, 10 p., W04006, doi: 10.1029/2004WR003692.

National Oceanic and Atmospheric Administration, 2006, Umpqua River, OR (P180), Bathymetric digital elevation model (30 meter resolution) derived from source hydrographic survey soundings collected by NOAA, metadata for raster version of Umpqua bathymetry in 1971: National Oceanic and Atmospheric Administration website, accessed July 6, 2011, at http://egisws01. nos.noaa.gov/servlet/BuildPage?template=bathy. txt\&parm1=P180\&B1=Submit.

National Oceanic and Atmospheric Administration, 2009a, Tidal station location and ranges-Oregon: accessed December 10, 2010, at http://co-ops.nos.noaa.gov/tides10/ tab2wc1b.html\#132.
National Oceanic and Atmospheric Administration, 2009b, National Geophysical Data Center, NOS Hydrographic Survey Data: National Oceanic and Atmospheric Administration, Office of Coast Survey, digital data, map scale 1:2,500 to 1:10,000, accessed December 10, 2010, at http://www.ngdc.noaa.gov/mgg/bathymetry/hydro.html.

National Oceanic and Atmospheric Administration, 2009c, Vertical datum transformation: National Oceanic and Atmospheric Administration website, accessed December 10, 2010, at http://vdatum.noaa.gov/.

Natural Resources Conservation Service, no date, Soil Survey Geographic (SSURGO) Database for Douglas County Oregon: U.S. Department of Agriculture, Natural Resources Conservation Service website, accessed October 24, 2010, at http://soildatamart.nrcs.usda.gov/.

O’Connor, J.E. Grant, G.E., and Haluska, T.L., 2003, Overview of geology, hydrology, geomorphology, and sediment budget of the Deschutes river basin, Oregon, in, O’Connor, J.E., and Grant, G.E., eds., A peculiar riverGeology, geomorphology, and hydrology of the Deschutes River, Oregon: American Geophysical Union Water Science and Application Series No. 7, p. 7-29.

O’Connor, J.E., Sarna-Wojcicki, A., Wozniak, K.C., Polette, P.J., and Fleck, R.J., 2001, Origin, extent, and thickness of Quaternary geologic units in the Willamette Valley, Oregon: U.S. Geological Survey Professional Paper 1620, 62 p., $1 \mathrm{pl}$.

O’Connor, J.E., Wallick, J.R., Sobieszczyk, Steven, Cannon, Charles, and Anderson, S.W., 2009, Preliminary assessment of vertical stability and gravel transport along the Umpqua River, southwestern Oregon: U.S. Geological Survey OpenFile Report 2009-1010, 40 p. (Also available at http://pubs. usgs.gov/of/2009/1010/.)

Onions, C.A., 1969, Sediment transport in streams in the Umpqua River basin, Oregon: U.S. Geological Survey Open-File Report, 45 p.

Oregon State University, 2010, Umpqua Basin Explorer, Natural Resources Digital Library, Umpqua Basin Watersheds: Corvallis, Oreg., Oregon State University, accessed December 8, 2010, at http://oregonexplorer.info/ umpqua/UmpquaWatersheds.

Oster, E.A., 1972, Flood profiles in the Umpqua River basin, Oregon, Part 1: U.S. Geological Survey Open-File Report, 119 p. 
Oster, E.A., 1973, Flood profiles in the Umpqua River basin, Oregon, Part 2: U.S. Geological Survey Open-File Report, $113 \mathrm{p}$.

Oster, E.A., 1975, Flood profiles in the Umpqua River basin, Oregon, Part 2: U.S. Geological Survey Open-File Report, 108 p.

PacifiCorp, 2002, Settlement agreement concerning the relicensing of the North Umpqua hydroelectric project, amendment No. 1, FERC No. 1927-008: PacifiCorp, 10 p., accessed November 8, 2010 at: http://www.pacificorp.com/ content/dam/pacificorp/doc/Energy_Sources/Hydro/Hydro Licensing/North_Umpqua_River/Settlement_Agreement Amendment No 1.pdf.

PacifiCorp, 2004, Analysis of project effects on sediment transport and river geomorphology, chapter 6, in Klamath Hydroelectric Project, FERC No. 2082: PacifiCorp, p. 6-1-6-170.

Parker, Gary, 1990a, Surface-based bedload transport relation for gravel rivers: Journal of Hydraulic Research, v. 28, no. 4, p. 417-436.

Parker, Gary, 1990b, The ACRONYM series of PASCAL programs for computing bedload transport in gravel rivers: St. Anthony Falls Laboratory, University of Minnesota, External Memorandum M-220, 124 p.

Parker, Gary, and Klingeman, P.C., 1982, On why gravel bed streams are paved: Water Resources Research, v. 18, no. 5, p. 1409-1423.

Parker, Gary, Klingeman, P.C., and McLean, D.G., 1982, Bedload and size distribution in paved gravel-bed streams: Journal of the Hydraulics Division, Proceedings of the American Society of Civil Engineers, v. 109, no. HY4, p. 54-571.

Personius, S.F., 1993, Age and origin of fluvial terraces in the central Coast Range, western Oregon: U.S. Geological Survey Bulletin 2038, 56 p.

Personius, S.F., Kelsey, H.M., and Grabau, P.C., 2003, Evidence for regional stream aggradation in the Central Oregon Coast Range during the Pleistocene-Holocene transition: Quaternary Research, v. 40, p. 297-308.

Pitlick, John, Cui, Y.T., and Wilcock, P.R., 2009, Manual for computing bed load transport using BAGS (Bedload Assessment for Gravel-bed Streams) software: Fort Collins, Colorado, U.S. Department of Agriculture, Forest Service, Rocky Mountain Research Station, General Technical Report RMRS-GTR-223, 45 p., accessed October 24, 2010, at http://www.stream.fs.fed.us/publications/bags.html.
PRISM Climate Group, 2007, PRISM Climate Group: Corvallis, Oreg., Oregon State University, digital data, accessed October 24, 2010, at http://www.prism. oregonstate.edu/.

Ramp, Len, 1972, Geology and mineral resources of Douglas County, Oregon: Oregon Department of Geology and Mineral Industries Bulletin 75, 106 p., 1 map sheet, scale $1: 250,000$.

Risley, J.C., 2004, Floods of November 1996 through January 1997 in the Umpqua River Basin, Oregon: U.S. Geological Survey Fact Sheet 2004-3134, 5 p.

Roering, J.J., Kirchner, J.W., and Dietrich, W.E., 1999, Evidence for non-linear, diffusive sediment transport on hillslopes and implications for landscape morphology: Water Resources Research, v. 35, p. 853-870, doi: 10.1029/1998WR900090.

Russell, P.P., 1994, Sediment production and delivery in Pistol River, Oregon and its effects on pool morphology: Corvallis, Oregon State University, MS thesis, 111 p., 29 figs.

Schmidt, K.H., 1985, Regional variation of mechanical and chemical denudation, upper Colorado River basin, U.S.A.: Earth Surface Processes and Landforms, v. 10, p. 497-508.

Scott, L.M., 1923, John Work's journey from Fort Vancouver to Umpqua River, and return, in 1834: Oregon Historical Quarterly, v. 24, p. 238-268.

Shaw, John, and Kellerhals, Rolf, 1982, The composition of recent alluvial gravels in Alberta river beds: Alberta Research Council Bulletin 41, p. 151.

Skovlin, J.M., Strickler, G.S., Peterson, J.L., and Sampson, A.W., 2001, Interpreting landscape change in high mountains of northeastern Oregon from long-term repeat photography: U.S. Department of Agriculture, Forest Service, Pacific Northwest Research Station, General Technical Report PNW-GTR-505, 78 p.

Smelser, M.G., and Schmidt, J.C., 1998, An assessment methodology for determining historical changes in mountain streams: U.S. Department of Agriculture, Forest Service, General Technical Report RMRS-GTR-6, 29 p.

Stednick, J.D., 2008, The new Alsea watershed study in Stednick, J.D., ed., 2008, Hydrological and Biological Responses to Forest Practices: Springer, v. 199, p. 115-121.

Stillwater Sciences, 1998, North Umpqua cooperative watershed analysis, Executive summary of the synthesis report, prepared for PacifiCorp, North Umpqua hydroelectric project, FERC Project No. 1927: Portland, Oregon, 55 p. 
Stillwater Sciences, 2000, North Umpqua cooperative watershed analysis, Technical appendix to the synthesis report, Appendix 2-1, Sediment budget for the North Umpqua River basin, Prepared for PacifiCorp, North Umpqua hydroelectric project, FERC Project No. 1927: Portland, Oregon, 113 p.

Stillwater Sciences, 2006, Technical memorandum, Gravel augmentation pulse experiment—August 2006 reconnaissance survey: Arcata, California, Stillwater Sciences, 3 p.

Syvitski, J.P.M., and Milliman, J.D., 2007, Geology, geography and humans battle for dominance over the delivery of fluvial sediment to the coastal ocean: Journal of Geology, v. 115, p. 1-19.

Tetratech, 2009, Upper North Santiam River gravel augmentation study—Final report: Portland, Oreg., prepared for North Santiam Watershed Council and U.S. Army Corps of Engineers, Portland District, 84 p.

U.S. Forest Service, 2003, Appendix C—Watersheds in Wildfire effects evaluation project: U.S. Forest Service, 16 p., accessed October 24, 2010, at http://www.fs.fed.us/r6/ umpqua/publications/weep-appendix-c.pdf.

U.S. Forest Service, 2006, Umpqua National Forest, frequently asked questions: U.S. Forest Service website, accessed October 24, 2010, at http://www.fs.fed.us/r6/ umpqua/faq/.

U.S. Forest Service, 2010, Umpqua National Forest Data Library, Geographic information systems, Metadata information: U.S. Forest Service database, accessed October 24, 2010, at http://www.fs.fed.us/r6/data-library/ gis/umpqua/metadata.shtml.

U.S. Geological Survey, 2008, Seamless data warehouse: U.S. Geological Survey database, accessed August 1, 2011, at http://seamless.usgs.gov/.

U.S. Geological Survey, 2010a, National Hydrography Dataset: U.S. Geological Survey dataset, accessed October 24, 2010, at http://nhd.usgs.gov/index.html.
U.S. Geological Survey, 2010b, National Water Information System, USGS water data for Oregon: U.S. Geological Survey database, accessed October 24, 2010, at http:// waterdata.usgs.gov/or/nwis.

U.S. Geological Survey, 2010c, Seamless Data Warehouse: U.S. Geological Survey National Elevation Data, 1/3 arc second digital elevation model, approximately $10 \mathrm{~m}$ resolution, accessed October 24, 2010, at http://seamless. usgs.gov/index.php.

U.S. Geological Survey, 2010d, StreamStats: U.S. Geological Survey digital data, accessed October 24, 2010, at http:// water.usgs.gov/osw/streamstats/index.html.

U.S. House of Representatives, 1871, On navigation of Umpqua River: House Miscellaneous Document, 41st Congress, 3rd session, No. 21.

U.S. House of Representatives, 1911, Examination of Umpqua River, Oregon: House Miscellaneous Document, 62nd Congress, 2nd session, No. 276.

U.S. Water Resources Council, 1981, Guidelines for determining flood flow frequency: U.S. Water Resources Council Bulletin 17B, 28 p.

Wallick, J.R., Anderson, S.W., Cannon, Charles, and O’Connor, J.E., 2010, Channel change and bed-material transport in the lower Chetco River, Oregon: U.S. Geological Survey Scientific Investigations Report 2010 5065, $68 \mathrm{p}$.

Walling, D.E., and Webb, B.W., 1983, Patterns of sediment yield, in Gregory, K.J., ed., Background to Paleohydrology: Chichester, England, John Wiley and Sons, p. 69-100.

Walter, Cara, and Tullos, D.D., 2009, Downstream channel changes after a small dam removal-Using aerial photos and measurement error for context; Calapooia River, Oregon: River Research and Applications, 26 p., accessed October 2010 at http://www.interscience.wiley.com, DOI: 10.1002/rra.1323.

Wampler, P.J., 2004, Contrasting styles of geomorphic response to climatic, anthropogenic, and fluvial changes across modern to millennial time scales, Clackamas River Oregon: Corvallis, Oreg., Oregon State University, Ph.D. dissertation, $398 \mathrm{p}$. 
Watershed Sciences, 2009, LIDAR remote sensing data collection-Umpqua River study area, Oregon: Portland, Oregon, prepared by Watershed Sciences for U.S. Geological Survey, Denver, Colorado, and Puget Sound Regional Council, Seattle, Washington, 34 p. with $1 \mathrm{~m}$ resolution digital data.

Webb, R.H., Leake, S.A., and Turner, R.M., 2007, Ribbon of Green-Change in riparian vegetation in the southwestern United States: Tucson, Arizona, University of Arizona Press, $480 \mathrm{p}$.

Wells, R.E., Jayko, A., Niem, A.R., Black, G., Wiley, T., Baldwin, E., and Molenaar, K.M., Wheeler, K.L., Givler, R., and DuRoss, C., 2001, Geologic map and database of the Roseburg, Oregon 30' x 60' Quadrangle, Douglas and Coos Counties, Oregon: U.S. Geological Survey Miscellaneous Investigations Map and Open-File Report OF00-376, 55 p., and 2 map sheets, scale 1:100,000.

Wemple, B.C., Jones, J.A., and Grant, G.E., 1996, Channel network extension by logging roads in two basins, western Cascades, Oregon: Water Resources Bulletin, v. 32, no. 6, p. 1195-1207.
Wilcock, P.R., 2001, Toward a practical method for estimating sediment-transport rates in gravel-bed rivers: Earth Surface Processes and Landforms, v. 26, no. 13, p. 1395-1408.

Wilcock, P.R., and Crowe, J.C., 2003, Surface-based transport model for mixed-size sediment: Journal of Hydraulic Engineering, American Society of Civil Engineers, v. 129, p. $120-128$.

Wilcock, P.R., Pitlick, John, and Cui, Y.T., 2009, Sediment transport primer-Estimating bed-material transport in gravel-bed rivers: Fort Collins, Colorado, U.S. Department of Agriculture, Forest Service, Rocky Mountain Research Station, General Technical Report RMRS-GTR-226, 78 p.

Winterbotham, J., 1994, Umpqua-The lost county of Oregon: privately published, $156 \mathrm{p}$.

Zilkoski, D.B., Richards, J.H., and Young, G.M., 1992, Special Report-Results of the general adjustment of the North American Vertical Datum of 1988: American Congress on Surveying and Mapping, Surveying and Land Information Systems, v. 52, no. 3, p. 133-149, accessed October 24, 2010, at http://www.ngs.noaa.gov/PUBS LIB/NAVD88/ navd88report.htm. 


\section{Appendix A. Location Information for Historical and Repeat Oblique Photography Completed for the Umpqua River, Oregon, Study Area}

Data are available for download at http://pubs.usgs/gov/sir/20115041.

\section{Appendix B. General Land Office Survey Notes and Approximate Location for Meandered Portions of the Umpqua River, Oregon, Between 1853 and 1894}

Data are available for download at http://pubs.usgs/gov/sir/20115041.

\section{Appendix C. Particle-Size Distributions at Sediment Sampling Sites in the Umpqua River Basin, Oregon, by Reach}

Data are available for download at http://pubs.usgs/gov/sir/20115041. 
112 Channel Change and Bed-Material Transport in the Umpqua River Basin, Oregon

This page intentionally left blank. 
Publishing support provided by the U.S. Geological Survey

Publishing Network, Tacoma Publishing Service Center

For more information concerning the research in this report, contact the Director, Oregon Water Science Center

U.S. Geological Survey

2130 SW 5th Avenue

Portland, Oregon 97201

http://or.water.usgs.gov 
气ั

웅

言

올 